UNIVERSIDADE DE SÃO PAULO

FACULDADE DE FILOSOFIA, LETRAS E CIÊNCIAS HUMANAS PROGRAMA DE PÓS-GRADUAÇÃO EM SOCIOLOGIA

GUILHERME RAMALHO ARDUINI

\author{
OS SOLDADOS DE ROMA \\ CONTRA MOSCOU: \\ A ATUAÇÃO DO CENTRO DOM VITAL \\ NO CENÁRIO POLÍTICO \\ E CULTURAL BRASILEIRO \\ (RIO DE JANEIRO, 1922-1948)
}

São Paulo

2014 
UNIVERSIDADE DE SÃO PAULO

FACULDADE DE FILOSOFIA, LETRAS E CIÊNCIAS HUMANAS

DEPARTAMENTO DE SOCIOLOGIA

PROGRAMA DE PÓS-GRADUAÇÃO EM SOCIOLOGIA

\section{OS SOLDADOS DE ROMA CONTRA MOSCOU: A ATUAÇÃO DO CENTRO DOM VITAL NO CENÁRIO POLÍTICO E CULTURAL BRASILEIRO (RIO DE JANEIRO, 1922-1948)}

Guilherme Ramalho Arduini

Tese apresentada ao Programa de PósGraduação em Sociologia do Departamento de Sociologia da Faculdade de Filosofia, Ciências e Letras da Universidade de São Paulo, para obtenção do título de Doutor em Sociologia.

Orientador: Prof. Dr. Sergio Miceli Pessôa de Barros

São Paulo 
Autorizo a reprodução e a divulgação total ou parcial deste trabalho, por qualquer meio convencional ou eletrônico, para fins de estudo e pesquisa, desde que citada a fonte.

Versão original disponível para consulta na biblioteca física da FFLCH/USP.

Arduini, Guilherme Ramalho

Os soldados de Roma contra Moscou: a atuação do Centro Dom Vital no cenário político e cultural brasileiro (Rio de Janeiro, 19221948). / Guilherme Ramalho Arduini; orientação do Prof. Dr. Sergio Miceli Pessôa de Barros. São Paulo: s.n, 2014.

200f.; il.

Tese (Doutorado)--Universidade de São Paulo. 2014. 
ARDUINI, Guilherme Ramalho.

Os soldados de Roma contra Moscou: a atuação do Centro Dom Vital no cenário político e cultural brasileiro (Rio de Janeiro, 1922-1948)

Aprovado em:

\section{BANCA EXAMINADORA}

Prof. Dr. Sergio Miceli Pessôa de Barros 
Para Eva, Silvana e Brenda, três Lilites.

Para dois Ceos: Thiago e Onivaldo. 


\section{AGRADECIMENTOS}

Esta tese materializa o apoio que recebi de muitas pessoas ao longo destes quatro anos e meio que, devo confessar, foram os mais agitados de minha vida. Mudei de residência (três vezes), de emprego e de estado civil. Espero ter acumulado um pouco do discernimento transmitido por tantos caminhantes com quem cruzei no caminho, cujos gestos e palavras demonstraram que há sempre algo de positivo em tantas mudanças porque elas possibilitam um jeito diferente de ver as coisas e um aprendizado. A lista de pessoas que contribuíram de diferentes formas para o sucesso deste trabalho é grande em comparação com minha curta memória, mas espero não esquecer ninguém.

Começo por aquele cujas ideias saem como flechas certeiras de sua mente: Sergio Miceli. A ele devo agradecer por me ter privilegiado com a orientação segura e desafiadora de quem já trilhou muitos caminhos a mais dos que começo a percorrer. Guardo de sua visão do método sociológico o desafio de pensar com os pés calçados com os dados empíricos e os olhos voltados a uma fecunda reflexão teórica.

Agradeço também aos professores Fernando Pinheiro e Marcelo Ridenti, arguidores implacáveis no momento da qualificação. O texto ganhou muito em profundidade de análise a partir de suas argutas observações. De antemão, sou grato aos professores da banca de defesa pelas observações e comentários realizados no momento da defesa.

Meu esforço de pesquisa seria impossível sem a existência de quatro figuras centrais de minha vida. A primeira a ser lembrada é a de meu irmão (ausência sempre presente), Thiago, pois sua vida durou o suficiente para revelar o valor de uma inteligência brilhante e transmitir a paixão pela leitura. Outras duas são meus pais, Onivaldo e Eva, a quem devo tudo que sou. E a quarta é minha esposa Silvana, cujo auxílio se estendeu para muito além de seus dotes de bibliotecária; suas palavras me deram estímulo e ânimo e suas mãos, conforto e descanso nas horas extremas.

O agradecimento seguinte se destina aos herdeiros de Tristão de Athayde, representados aqui pelas famílias Alceu Amoroso Lima Filho e Carlos Eduardo Affonso Ferreira (Xikito). Recebi de seu interesse por minha pesquisa um grande estímulo para prosseguir no encalço dos múltiplos lados desta figura ímpar da história brasileira.

Agradeço aos meus colegas de trabalho que compreenderam a necessidade de minha ausência durante o término da tese e me auxiliaram a obter da Assembleia 
Legislativa do Estado de São Paulo o afastamento para o mês de maio de 2014. Eles não foram os únicos a me agraciar com palavras de incentivo: pelo mesmo motivo agradeço aos meus sogros, Edileusa e Cido, à minha cunhada Cristiane e aos amigos da Instituição Teresiana. Foi através da IT conheci modelos de dedicação ao ensino e a pesquisa: Brenda Carranza, Concha Valverde e Pedro Ghirardi.

Por fim, meu "muito obrigado" aos funcionários dos diversos arquivos e bibliotecas pesquisados e aos leitores que contribuíram com sugestões para a melhoria do texto, entre os quais ressalto a figura de Camila Gui Rosatti. Espero que as linhas seguintes estejam à altura da contribuição de tod@s vocês. 
É positivamente de desanimar o contraste entre o que eu sinto que deveria ler e estudar e o que o tempo me permite fazer.

A vida que sou forçado a levar, sem perder um minuto em divertimento algum, pois nem ao cinema tenho ido, e portanto só perco tempo com o ganha-pão, essa vida não é de forma alguma para um homem de responsabilidade intelectual, quanto mais para um que ainda está procurando resolver os problemas fundamentais.

(Carta de Alceu a Jackson, 06 de março de 1928) 


\section{RESUMO}

A tese discute formas de recrutamento e atuação conjunta na cena política e intelectual brasileira de um grupo de profissional liberais e universitários chamado Centro Dom Vital, situado no Rio de Janeiro mas com ramificações em várias cidades, com destaque para o Nordeste e Minas Gerais. O estudo tem como seu marco inicial o ano de 1922, no qual ocorreu a fundação do Centro e o lançamento do primeiro livro de uma de suas figuras-chave: Alceu Amoroso Lima.

O marco final é 1948, data em que ocorre a última de uma série de alterações que esvaziam a atuação do grupo: a morte de seu primeiro diretor espiritual, Pe. Leonel Franca. Durante este quartel de século, os vitalistas (isto é, os frequentadores do Centro) publicaram dezenas de livros, editaram uma revista mensal (A Ordem) e tiveram um papel fundamental na configuração das políticas públicas ligadas à educação e ao trabalho.

A estrutura da tese consiste em um primeiro capítulo sobre as relações entre política e cultura durante o regime Vargas, seguido de uma apresentação da morfologia do grupo. Os quatro últimos capítulos apresentam o conjunto de livros e ações a partir de quatro temáticas: 1) a crítica literária; 2) a educação e as relações entre ciência e fé; 3) as hagiografias contemporâneas, isto é, biografias que servem de fonte para a formação de um panteão moral e 4) a política partidária. 


\begin{abstract}
This thesis discusses the ways of recruiting and acting together in the Brazilian political and intellectual scene of a group of Law Students and liberal professionals called Centro D. Vital, located in the city of Rio de Janeiro but with branches in many other cities, namely in the North East of Brazil and in the State of Minas Gerais. The chronological boundaries of this study are the years of 1922 - when the Centre was founded and one of its key figures, Alceu Amoroso Lima, published his first book - and 1948, with the decease of Father Leonel Franca, SJ, the spiritual leader. His absence changed the identity of the group, but was only the last event in a chain of milestones that undermine its importance.

In the quarter of a century between these two dates, the vitalistas (i. e., those who shared the ideas and values widespread by the Centre) published dozens of books, issued a monthly review (A Ordem) and had a pivotal role in some educational and working class policies.

The structure of the thesis consists in a first chapter on the relationship between politics and culture in Getúlio Vargas' regime (1930-1945), followed by the presentation of the morphology of the group. The last four chapters present the ensemble of books and actins written by them, divided by the themes: 1) literary critics; 2) the education and the relationship between science and faith; 3) contemporary hagiographies, i.e, biographies that work as sources for the making of a pantheon of models; 4) politics.
\end{abstract}




\section{SUMÁRIO}

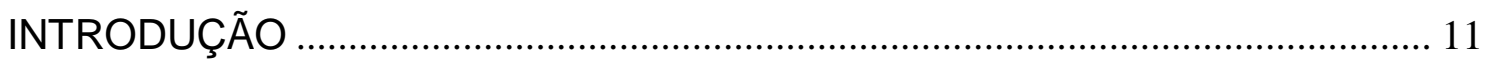

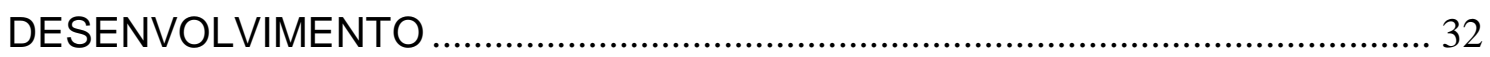

Capítulo I: Delimitação do problema a partir da bibliografia ................................... 33

Capítulo II: O Grupo em Estudo ........................................................................... 49

Capítulo III: A Crítica Literária........................................................................ 79

Capítulo IV: Ensino religioso, educação e as relações entre ciência e fé ......... 102

Capítulo V: As Hagiografias (e outros gêneros apologéticos) ............................. 132

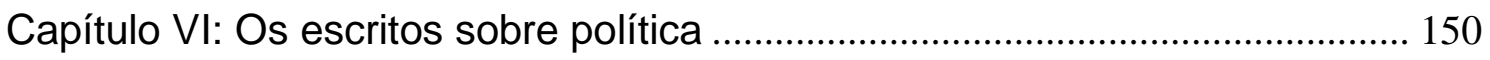

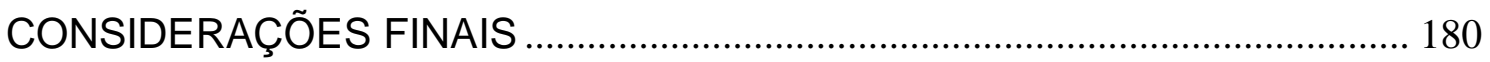

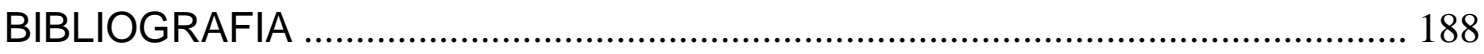




\section{INTRODUÇÃO}

"A nova geração começava a surgir marcada pelo sinal de Roma ou de Moscou"

(Alceu Amoroso Lima, 1958) 
A tese tem como seu problema central compreender o grupo de frequentadores do Centro Dom Vital, a instituição que a Igreja Católica, na figura do arcebispo e cardeal do Rio de Janeiro (Sebastião Leme ${ }^{1}$ ), designava como a preferencial para o público de universitários e profissionais liberais domiciliados na capital federal. Este trabalho pretende demonstrar que o pertencimento ao grupo estava condicionado por afinidades de ideias, investimentos afetivos e expectativas que se materializaram em uma revista (A Ordem), livros publicados entre as décadas de 1920 e 1940 e em diversas outras associações.

O problema surge da constatação de que há dois perfis que se repetem entre os participantes do Centro. Durante a década de 1930, um grupo de aucistas (isto é, aqueles que faziam parte da Ação Universitária Católica, também conhecida por sua sigla AUC) dispenderam sua energia para expandir a atuação do Centro. Criada em 1929 e englobada pela Ação Católica em 1935, ela foi a aplicação no Brasil do preceito do Papa Pio XI para todo o orbe católico, conhecendo congêneres em todos os países europeus. Ele desejou aplacar as demandas dos leigos por uma maior participação na vida eclesial de modo estritamente organizado pela hierarquia.

Gramsci interpreta a criação da Ação Católica na Itália como o resultado da perda de hegemonia na esfera pública. Quando Roma perde o controle da vida social, se vê instada a criar um "partido católico" para participar das discussões políticas, econômicas e culturais na tentativa de recuperar este domínio. Christiane Jalles de Paula $^{2}$ vislumbra na criação do Centro Dom Vital e da AUC a resposta do clero brasileiro a problema idêntico ao da Igreja italiana.

Os aucistas conviveram com a "geração de 1893", da qual, observa Riolando $\mathrm{Azzi}^{3}$, se originaram diversos dos fundadores do Centro, nascidos na última década do século XIX. A existência de um grupo com essas características em comum provoca a curiosidade em compreender o que levou a se formar um número tão elevado de conversões ao mesmo tempo, na mesma cidade. E que prossegue na tentativa de

\footnotetext{
${ }^{1}$ Para saber mais sobre a trajetória social de Dom Leme, consultar o capítulo II desta tese.

${ }^{2}$ RODRIGUES, Cândido Moreira; PAULA, Christiane Jalles de. Intelectuais e militância católica no Brasil. Cuiabá: Editora UFMT, 2012, p. 75-95.
}

${ }^{3}$ AZZI, Riolando. Os pioneiros do Centro Dom Vital. Rio de Janeiro: Educam, 2003. 
enxergar o rendimento que este número elevado de conversões provocou para as demandas da Igreja nos diversos ambientes de atuação dos convertidos.

Historicamente, na Igreja Católica, a experiência da conversão implica um reordenamento psíquico e nos hábitos de vida. Danièle Hervieu-Lèger ${ }^{4}$ ressalta como o ato de converter-se, mesmo quando vivido como uma experiência íntima, é condicionado pela bagagem de experiências sociais acumuladas pelo convertido e as aspirações que orientaram esta decisão. Os convertidos do início do século XX francês tinham um vasto repertório cultural traduzido em uma leitura do catolicismo relativamente distinta do apego aos valores do Concílio Vaticano I, propagados por Roma. A conversão representou naquele momento histórico um processo de individualização e subjetivação da experiência religiosa, em resposta a uma vivência da sociedade ambiente como hostil e na projeção de outra sociedade harmoniosa na qual se pretendia ingressar, ainda que no presente ela fosse mera utopia. Segundo a autora, o fortalecimento na França dos anos 1930 de uma organização como a Ação Católica, mais controlada diretamente pela hierarquia e portanto menos aberta a este tipo de experiência, resultou na diminuição deste fenômeno.

No caso dos brasileiros, a conversão também dependeu das proximidades e laços afetivos resultantes das experiências estéticas e culturais compartilhadas. A crítica ao cientificismo característico da Belle Époque era consensual no grupo. Na literatura, a poesia parnasiana e a prosa de Machado de Assis davam lugar à poesia simbolista e sua busca por expressar o mistério envolvente ao ser humano. Cândido (2006) cartografa os vínculos entre a filosofia de Farias Brito (assumido pelo grupo como uma de suas principais leituras), a crítica literária de Nestor Vitor e o apostolado de Jackson de Figueiredo. Ao optar por chamar a participação de Figueiredo de "apostolado", implicitamente indica a falta de importância dos escritos do autor sergipano, cujo legado se dá mais por sua ação do que pela força das ideias e do texto.

Os diversos discursos políticos respondem à crise dos valores liberais definidos na Constituição de 1891, que perdiam espaço para as alternativas de direita, exigindo dos letrados dos anos 1920 um posicionamento. As evidências de que as regras do jogo eleitoral definidores da vida política da Primeira República haviam demonstrado seu cansaço eram inúmeras: o conturbado processo eleitoral pelo qual Arthur Bernardes

\footnotetext{
${ }^{4}$ HERVIEU-LÉGER, Danièle. O peregrino e o convertido: a religião em movimento. Petrópolis: Editora Vozes, 2008.
} 
conquistou a presidência da República, as sedições militares que espocaram em São Paulo e no Sul ou a situação das finanças públicas, problemáticas durante toda a década.

O grupo foi criado por Jackson de Figueiredo em uma das reuniões do grupo de amigos no Café Gaúcho em 1922. Após sua morte sua personalidade é descrita como um "soldado de Cristo", em uma imagem sugestiva de que há um inimigo a ser combatido e que a luta se anunciava renhida, exigindo a dedicação completa - como a do soldado com seu Exército. A metáfora será retida pela tese em virtude de seu potencial explicativo dos embates intelectuais nos quais adquire sentido a conversão coletiva.

Ao investigar o tema, um capítulo relevante da história intelectual brasileira dos anos 1920 a 1940 se descortinará aos nossos olhos, pois interpretar este grupo inclui compreender também o tipo de inserção dos intelectuais nas estruturas burocráticas do Estado brasileiro dos anos 1930, assim como o mercado editorial e algumas outras atividades de onde os profissionais das letras poderiam auferir ganhos simbólicos e financeiros. Há um ganho significativo na interpretação em conjunto de ambas as décadas, pois as importantes inovações ocorridas durante a década de 1930 - a começar pela quebra da ordem legal e o fim do pacto federalista - são desdobramentos das condições existentes na década anterior. Exemplo disso são as alianças construídas em Minas durante a década de 1920, que permitiram a Gustavo Capanema projetar-se na cena nacional como Ministro da Educação a partir de 1934.

Antes de prosseguir, é mandatório um breve parêntesis sobre o modo pelo qual será tratado aquele que foi, certamente, o personagem mais importante do grupo em estudo. A opção da tese foi utilizar com maior frequência, ao longo de todo o texto, o pseudônimo "Tristão de Athayde", de uso constante no período, embora seja importante ressalvar que este autor voltou no período seguinte a assinar seus textos com o nome. Amoroso Lima criou o pseudônimo, em 1919, e posteriormente justificou sua ação por um temor que a ocupação com a crítica literária fosse prejudicar sua reputação como administrador da empresa da família (LIMA, 1973).

Ainda segundo sua narrativa, por descuido teria deixado uma crônica literária assinada com o pseudônimo em sua mesa de trabalho, sabotando a si mesmo. Na medida em que se consagra como crítico, é possível encontrar referências em seus

\footnotetext{
${ }^{5}$ GOMES, Perillo. O Apologista, A ordem. Rio de Janeiro: Centro Dom Vital, ano VIII, n. especial, mar. 192, p.190-203.
} 
escritos ou em comentários a seu respeito nos jornais da época tanto pelo nome como pelo pseudônimo. Não é possível observar diferenças significativas de menção a um deles -- ou aos dois juntos -- relacionadas ao tipo de texto escrito. Se as críticas literárias são o motivo pelo qual se cria o pseudônimo de Tristão de Athayde, os ensaios sociológicos produzidos durante o período por esta tese também aparecem assinados dessa forma, por vezes acompanhados do nome completo.

Uma análise de livros publicados durante o período entre 1930 e 1974 sugere que a opção entre os nomes poderia estar ligada à postura política deste autor, tendo como base a cronologia no uso dos termos. Entre os anos de 1930 e 1943, todos os livros lançados trazem na capa "Tristão de Athayde", acompanhado do nome completo em nove dos quinze casos. Em oposição, de 1946 em diante os livros aparecem assinados exclusivamente sob o nome de Alceu Amoroso Lima. Ainda que sem desejar renegar o Tristão que existia, Alceu pretende sinalizar que as posturas políticas antigas desapareceram. Guilherme Simões Gomes Júnior ${ }^{6}$ possui uma visão ligeiramente distinta da apresentada até aqui, concluindo que o pseudônimo seria o sinal de uma busca por uma identidade, ainda em construção. A ideia é arguta, e pode ser complementada com a constatação de que na medida em que Alceu se converte, a crise de identidade deixa de ser perceptível, ainda que o uso dos dois nomes se mantenha. Essa decisão poderia advir da facilidade em identificar o crítico literário (pseudônimo) com o líder católico presidente de diversas associações (nome de batismo).

Em vista dos problemas apresentados, a opção metodológica mais pertinente é a combinação da biografia coletiva com uma análise das obras. Da primeira procura-se trazer o interesse para as constantes de comportamento nas famílias e nos grupos políticos, estabelecendo um interessante diálogo entre tais características e o singular/circunstancial, mais próximo da individualidade dos sujeitos. Este estudo se pretende uma expansão dessa corrente para o terreno da cultura, onde certamente ele é menos utilizado. Uma hipótese para explicar este uso menos intenso pode ser a dificuldade de lidar com objetos como livros, artigos e cartas, pois eles são concebidos como o espaço por excelência de manifestação da subjetividade de seu autor, e portanto menos afeitos a análises de grupo.

${ }^{6}$ GOMES JÚNIOR, G. S. Crítica, combate e deriva do campo literário em Alceu Amoroso Lima. Tempo Social, São Paulo, v. 23, p. 101-133, 2011. 
A biografia coletiva possui uma longa história da qual faz parte até a mudança de nome, visto ter sido ela originalmente concebida com o nome de prosopografia. Este permanece sendo o termo empregado para denomina-la em países anglófonos ou nas áreas do conhecimento mais tradicionais - História Antiga e Moderna - de outros países. Pensada inicialmente para compreender estruturas de parentesco ou relações clientelísticas na política, seu uso se expandiu para fontes muito distintas dos trabalhos originais, como ocorreu com o estudo de Sergio Miceli sobre a elite eclesiástica brasileira $^{7}$. Nele se apresentam os mecanismos de recrutamento, formação e premiação de algumas carreiras eclesiais, expondo a nu as regras que regem o funcionamento de uma instituição com alto nível de burocratização, como é o caso da Igreja Católica ${ }^{8}$.

Ao lado do trabalho de Miceli, as preocupações teóricas expressas em Stone ${ }^{9}$ e na coletânea organizada por Flávio Heinz ${ }^{10}$ permeiam as inquietações que deram origem a este trabalho. As possibilidades vislumbradas no método prosopográfico incluem apostas altas: construir pontes entre a preocupação sociológica de encontrar as características constantes que conformam a criação de grupos sociais e a intenção ideográfica dos historiadores; unificar a História Social e a Política, reestabelecendo a ligação entre a instituição e o indivíduo que atua em seu interior. Ou ainda oferecer uma alternativa a certa forma de marxismo calcado no papel dos grandes grupos como atores sociais, equilibrando esta fator explicativo com a importância da ação individual.

Sem ter a pretensão de realizar tantas promessas, este trabalho enxergou no uso da biografia coletiva, em acréscimo à análise das obras escritas durante este período, a possibilidade de explicar as transformações de um grupo de poetas, críticos e ensaístas que partilham as páginas das mesmas revistas, citam-se frequentemente uns aos outros e, mais importante, revelam uma aproximação de ideias sobre o tipo de organização social a ser privilegiado, com o papel da Igreja e do intelectual na produção da ciência e da arte. Não é apenas notável que o Centro tenha se constituído, ou que alguns de seus representantes tenham alcançado tamanho prestígio individualmente, mas que o coletivo

\footnotetext{
${ }^{7}$ MICELI, Sergio. A elite eclesiástica brasileira. São Paulo: Companhia das Letras, 2009.

${ }^{8}$ Algo semelhante é apresentado para o Exército, com conclusões relativamente próximas às da Igreja. Ver MICELI, Sergio. Intelectuais à Brasileira. São Paulo: Cia das Letras, 2001.

${ }^{9}$ STONE, Lawrence. Prosopografia, Revista de Sociologia e Política, Curitiba, v. 19, n. 39, p. 115-137, jun. 2011.

${ }^{10}$ HEINZ, Flávio. Por uma outra história das elites. Rio de Janeiro: FGV, 2006.
} 
do grupo tenha se estabelecido como um ator social importante para o período, sendo chamado a opinar nos debates sobre educação, cinema, literatura e costumes.

O sucesso obtido por Jackson de Figueiredo, Tristão de Athayde e Leonel Franca é por vezes visto interpretado pela bibliografia na chave das exceções, como se suas trajetórias tivessem transbordado a magnitude do Centro Dom Vital. Entretanto, a observação de outros casos, como o de Jônathas Serrano ou o de Everardo Backheuser, mostra que há efeitos de consagração que não se resumem aos principais expoentes do grupo e se espalham pelas atividades do dia-a-dia do controle administrativo de novas escolas, da censura a filmes e da formação de professores - para citar as atividades nas quais se envolveram os nomes citados. Outras considerações sobre o uso histórico das biografias coletivas podem aclarar sus possibilidades de uso nesta pesquisa.

A biografia coletiva foi pensada inicialmente em conexão com uma teoria das elites, cuja discussão se iniciou nas primeiras décadas do século XX com os trabalhos de Gaetano Mosca e Vilfredo Pareto ${ }^{11}$, ganhou novos sentidos ao longo de todo o século. Em sua formulação inicial, a teoria das elites era a expressão de uma descrença dos princípios democráticos a reger a vida política de um país, a partir do estudo dos grupos que monopolizaram o controle do poder estatal.

As fontes empregadas para este tipo de estudo eram via de regra as seriais, das quais se retiraram dados quantitativos capazes de formar uma visão ampla da morfologia de uma população definida. Por outro lado, o desenvolvimento da história social e da história econômica reaproveitaram a teoria das elites com a finalidade de resolver algumas de suas tensões intrínsecas a partir da redução na escala de observação. Os usos mais produtivos da biografia coletiva nasceram de seu uso em pequenos nichos para os quais houvesse uma quantidade considerável de informações, enfrentando dilemas metodológicos como os seguintes: privilegiar os grandes grupos sociais ou centrar-se nos grupos menores? Registrar conclusões em níveis mais altos de observação ou detalhar o estudo sobre uma população reduzida?

Este trabalho comunga da opinião de Christophe Charle ${ }^{12}$ sobre a pertinência de se optar por uma escala de análise mais reduzida em benefício de uma riqueza maior de

\footnotetext{
${ }^{11}$ Gaetano Mosca, Elementi di scienza politica (1896) e Vilfredo Pareto, Systèmes socialistes (1902) e Tratatto di sociologia generale (1916).

${ }^{12}$ CHARLE, Christophe. Como anda a história social das elites e da burguesia?: tentativa de balanço crítico da historiografia contemporânea. In: HEINZ, Flávio. Por outra história das elites. Rio de Janeiro: FGV, 2006, p. 19-40.
} 
detalhes e análises. Isso não impede, é claro, um diálogo desta tese com questões mais gerais concernentes à história brasileira, como aquela que trata da renovação e da reprodução das elites políticas no Brasil dos anos 1930.

O fato de incluir a produção livresca como objeto de pesquisa conduz à necessidade de pensar nos diferentes tipos de determinação em jogo para explicar a conformação de um objeto tão complexo. Dois desafios marcam a interpretação da obra: a primeira, recusar a compreensão da obra de arte como sendo em seu último sentido inefável e fora da definição de sociólogos, historiadores ou quaisquer outros especialistas, já que ela se apresentaria como uma manifestação do gênio artístico único e insubstituível de seu autor.

Em resposta a essa abordagem, Bourdieu (1996) aponta as contribuições propiciadas pela sociologia da cultura para a compreensão da singularidade do autor ao situar melhor suas escolhas dentro do seu espaço de atuação, em relação aos outros escritores e a outros agentes no processo de criação literária. Ao recusar-se a abordar a expressão artística como algo transcendente, não se diminui o valor de seu criador; pelo contrário, o método apresenta a vantagem de pôr a nu o modo como ele se relaciona com as constrições atuantes durante o processo de criação, trazendo a apreensão da obra ao alcance de todos.

É por este motivo que se decidiu incluir entre os objetivos deste trabalho uma análise interna e comparativa entre as obras, estabelecendo pontes entre o que elas nos dizem e o que a trajetória social de seus autores permite estabelecer. A ideia de trajetória social, tal como utilizada neste texto, deve muito às considerações de Pierre Bourdieu sobre os distintos universos de produção simbólica da França (o mundo das artes, o sistema universitário, a literatura e o mundo dos salões literários e artísticos). As diferenças entre o período sob o escrutínio de Bourdieu e os anos 1920 a 1940 no Brasil não invalidam a importância de se levar em consideração o conjunto de fatores a localizar cada indivíduo em uma determinada posição social, sempre em relação a outros indivíduos inseridos na mesma lógica de classificação. Entre tais fatores estão a profissão e o grau de sucesso obtido nela; o modo de inserção dentro do sistema familiar e a importância do clã do qual participa na sociedade de seu tempo. Estas e outras características (formação escolar e diplomas, atuação profisssional, círculo de amizades e de contatos) configuram a liberdade criativa dos autores e deixam suas marcas na produção intelectual, tornando-se ferramentas de inteligibilidade. 
Outro desafio enfrentado neste trabalho é preocupar-se com o sentido de uma obra, construído coletivamente na reapropriação por meio de disputas a partir dos quais se justifica seu surgimento como um produto social, autônomo em relação à consciência individual de onde se originou. É necessário perguntar-se, como fez Sergio Miceli (2009) sobre as relações de poder subjacentes à produção de um texto. Em seu caso, tratavam-se de biografias de bispos da Primeira República, geralmente redigidas por epígonos interessados em apresentar o nome de seus protetores como portadores de distinções em relação aos pares, apresentadas como "dom", "graça" ou fruto de uma "vocação". As obras a serem analisadas no presente trabalho apresentam algumas semelhanças com estas observações, como a relação de proteção e prestígio entre o autor e o tema da obra, fato especialmente válido quando pensado para os estudos biográficos redigidos pelo grupo ${ }^{13}$. A redação e divulgação dos escritos analisados estão intrinsecamente relacionadas às expectativas de uns autores sobre os outros do grupo, na maioria dos casos em busca de proteção e projeção.

Também deve ser levada em conta a estratégia desenhada pelo Papa Pio XI para toda a Igreja Católica, de incluir a participação do laicato na luta pela manutenção do prestígio da instituição frente ao espaço cada vez mais reduzido que a Igreja ocupava na cena pública do mundo ocidental. Por outro lado, a situação financeira e a coesão interna do clero nacional nunca estiveram em tão boas condições como os anos 1920. Depois do aumento considerável de padres através da vinda de diversas congregações estrangeiras e de um surto de vocações brasileiras, as discussões sobre o celibato e a ocupação com a política do país pareciam realidades cada vez mais distantes, relegadas ao longínquo passado dos padres liberais no Império. Casos de indisciplina, como o do Padre Cícero, eram raros e não afetavam a autoimagem do clero.

Entre as fontes consultadas, destacam-se os livros publicados pelos membros do Centro Dom Vital, as notícias de jornal a seu respeito e as correspondências trocadas entre eles. No primeiro caso, também é importante levar em consideração a diversidade de tipos de produção livresca, com públicos muito distintos. O nome de Amoroso Lima já estava consagrado na crítica literária e de sociologia do período em nível muito superior aos seus pares. Entre os fundadores, Jackson de Figueiredo investiu em diversas frentes, publicando um tratado de filosofia, outro sobre literatura, uma coletânea de escritos políticos...

${ }^{13}$ A este respeito, conferir o capítulo V desta tese. 
É sintomático que este padrão só encontrasse um paralelo em Tristão de Athayde, com a diferença de que este já produzira obras de grosso calibre antes da conversão. Entre os vitalistas de primeira hora, Vilhena de Moraes publicou uma biografia do Duque de Caxias e algumas obras sobre o estudo da língua latina, mas seria exagero dizer que se tratava de um nome aclamado pela imprensa do período. O mesmo vale para Jônathas Serrano, que terminou por se dedicar à produção de manuais de História, utilizados por diversos colégios e que se tornaram best-sellers.

Esta não foi, entretanto, a única forma de consagração atingida pelos membros do grupo. Especialmente ao final da década, alguns deles alcançariam um prestígio maior quando seus livros passaram a ser publicados pela José Olympio, consagrada como a mais importante do período. Não obstante as críticas recebidas por editar livros integralistas e os discursos de autoridades (a começar por Vargas), essas atitudes eram vistas pelos escritores editados pela casa na época como necessárias em compensação aos riscos financeiros e políticos indissociáveis da profissão de editor. Os leitores integralistas, por exemplo, eram garantia certa de público e o bom relacionamento com o Estado Novo permitiu-lhe publicar autores comunistas. Amoroso Lima publicou pela editora entre o final da década de 1930 e início da década de 1940, ao passo que Leonel Franca aí trouxe à lume A Crise do Mundo Moderno em $1941^{14}$.

A observação sobre José Olympio pode conduzir o leitor a se perguntar sobre o sentido político das publicações feitas em apreço, visto que dividiam espaço no mesmo catálogo com livros integralistas, comunistas, etc. Como referenciais teóricos, é possível pensar em dois autores que trataram de modos distintos a inserção política de profissionais dedicados ao trabalho de produção de textos. Em seu texto sobre Heidegger ${ }^{15}$, Bourdieu chama a atenção para os mecanismos de eufemização a exigirem um trabalho de decriptagem para entender o sentido político implícito ao que está escrito. O raciocínio é extensível ao ambiente carioca e aos escritos dos vitalistas, para perguntar-se sobre os sentidos escondidos do político.

\footnotetext{
${ }^{14}$ No caso de Amoroso Lima, os livros foram: No limiar da Idade Nova (1935), O Espírito e o Mundo (1936), Idade, Sexo e Tempo (1938) e Contribuição à história do modernismo. O prémodernismo (1939). Meditação sobre o Mundo Moderno, Pela União Nacional, Mitos de Nosso Tempo (todos em 1942) e O Cardeal Leme (1943). Leonel Franca publicou apenas um livro: A crise do mundo moderno (1941).

15 BOURDIEU, Pierre. The political onthology of Martin Heidegger. Stanford: Stanford University Press, 1991.
} 
Adriano Codato ${ }^{16}$ propõe uma maneira complementar de pensar na interação entre saber científico e político, neste caso especificamente a partir do contexto brasileiro dos anos 1930, ou mais especificamente sobre os mecanismos de seleção para ingresso no universo da política e do mundo científico. Diferentemente da cultura política oligárquica da Primeira República, cuja lógica de funcionamento apontava para a necessidade de se pertencer a um clã para ser aceito, o político semiprofissional marcaria o período e faria paralelo à figura do cientista no campo acadêmico, e do beletrista no universo das artes. Todos eles apresentam alguma forma de mérito próprio, geralmente uma formação especializada, como o critério para terem direito ao posto que ocupam. A hipótese de Codato pode ser útil para ajudar a pensar nas representações feitas por vitalistas e adversários da arena onde eles se enfrentam e das condições de luta. Os critérios do que pode ser considerado científico estão em constante disputa, e os vitalistas apresentam seus argumentos, baseados na ideia do científico definido a partir do religioso. Seus adversários, naturalmente, procuram justificar o discurso oposto.

O período em estudo inicia-se em 1922 porque este é o ano de fundação do Centro Dom Vital, uma organização que ressignifica a prática do catolicismo entre a elite intelectual carioca e, em certa medida, nacional. Sua criação só se torna compreensível a partir do regresso de Sebastião Leme ao Rio de Janeiro em 1921. Tendo sido escolhido como o chefe efetivo da Arquidiocese do Rio de Janeiro ${ }^{17}$, ele se preocupou em direcionar a atividade dos leigos no sentido de aumentar o peso da arquidiocese na vida pública carioca. Por abrigar o centro político do país, ela era o espaço por excelência de discussão das principais políticas públicas do momento, especialmente aquelas em expansão (por exemplo, a educação básica universal). Por este motivo, os frequentadores do Centro (fração considerável da elite econômica e cultural carioca), assumiram o papel de representante da Igreja neste e nos demais setores da vida social.

O marco final da tese coincide com o final do Estado Novo. Naquele contexto, as diversas alterações acumuladas tornaram difícil tratar do grupo como algo coeso, ao

\footnotetext{
${ }^{16}$ CODATO, Adriano. A transformação do universo das elites no Brasil pós-1930: uma crítica sociológica. In: HEINZ, Flavio M. História social de elites. São Leopoldo: Oikos, 2011, p. 5673.

${ }^{17}$ Embora ainda fosse nominalmente o Arcebispo, o Cardeal Arcoverde havia se retirado da cidade em virtude de seu estado de saúde fragilizado. O Vaticano indicou um bispo auxiliar, Sebastião Leme, que também recebeu a confirmação do direito à sucessão, o que lhe permitiu iniciar com certo grau de segurança um trabalho a longo prazo.
} 
qual se pudesse designar com um conceito próprio como o de "vitalismo". Sob este nome e seus derivados - como "vitalista" - será tratado o conjunto de pessoas, escritos e ações que marcaram a identidade do grupo ao longo do período em questão. $\mathrm{O}$ uso implica alguns pressupostos básicos: o primeiro, de que houve uma participação relevante desta instituição na vida pública do período. Como será demonstrado ao longo deste trabalho, há diversos sentidos para esta relevância: a ocupação de postos na burocracia federal, de espaço na imprensa e no debate público, ou ainda na formação esmerada de uma nova geração de prelados, os quais tradicionalmente alcançariam postos de grande destaque na Igreja.

Um destes elementos foi a frequência com a qual eles apareciam nos sumários da Ordem, nas suas comissões temáticas e nos livros publicados durante o período. Hamilton Nogueira, por exemplo, não apenas fundou o Centro como foi escolhido seu vice-presidente de 1922 a 1928. Com a reorganização do Centro em comissões temáticas, motivada pelo novo presidente Amoroso Lima, tornou-se presidente da Comissão de Biologia, disciplina da qual viria a ser professor na fundação do Instituto Católico de Estudos Superiores (1932). Na revista A Ordem, colaborou com oito artigos entre 1928 e 1932.

Perillo Gomes era responsável por uma seção da revista ("Registro") e publicou alguns dos livros que formaram a coleção da editora durante a década de 1920. São obras de apologia da fé católica, combate a outras crenças ou de cunho político: Penso e Creio (com primeira edição esgotada em 1921), Ensaios de Crítica Doutrinária (1923), A Theosofia (1924); Polêmica e Doutrina (1925); O Laicismo e Jackson de Figueiredo - o doutrinador político (1926); D. Vital (1932) e O Liberalismo (1933).

Tasso da Silveira divulgou seus poemas em A Ordem desde o início da década de 1930. Antes disso, já havia engrenado uma colaboração com Jackson de Figueiredo em 1919, em um movimento conhecido por seu antilusitanismo e uma visão passadista da História, expressa através da revista Gil Blas. Seus livros foram acompanhados de perto por Alceu na série Estudos, que o saúda como um dos modernistas que escaparam da fúria destrutiva do movimento pau-brasil, ocupando-se com um objetivo que eles reputavam mais produtivo: a reforma espiritual do povo brasileiro. Era um dos principais nomes do simbolismo na poesia e foi convidado para integrar o corpo docente 
da Faculdade Santa Úrsula, da Universidade Católica e da Universidade do Brasil. ${ }^{18}$ A presença nos três institutos universitários é outro traço que o une a Amoroso Lima, Hamilton Nogueira e Sobral Pinto.

Ao longo da década de 1940, acumulam-se alterações que modificam sensivelmente o Centro Dom Vital, sua função social e, consequentemente, sua importância. Do ponto de vista das lideranças, as mortes de dom Leme, em 1942, e Leonel Franca, em 1948, retiram dos "vitalistas históricos" seus principais pontos de apoio e de referência, vulnerabilizando-os frente às lideranças emergentes, de cunho marcadamente mais arisco ao diálogo com a cultura secular. No bispado de Dom Jayme Câmara, sucessor de Dom Leme, Gustavo Corção assume a posição de liderança do Centro graças à sua afinidade de pensamento com o bispo. Ao nível interno do grupo, a disposição para admitir mudanças nos pontos de vista é cada vez mais difícil, mas os fatores externos ao grupo se movimentam no sentido contrário.

O final da II Guerra Mundial e do Estado Novo tornam mais problemático o diálogo entre um catolicismo de viés politicamente autoritário e uma sociedade crescentemente laicizada. A situação exige uma abertura no compasso a traçar o círculo de vozes a incluir no debate, e, mais importante ainda, uma mudança de atitude frente a estas vozes, a fim de apagar a herança do apoio ao autoritarismo que marcou o grupo ao longo da década de $1930^{19}$.

As alterações no contexto de atuação reverberaram na construção da memória de seus membros, em um processo de ressignificação do vivido de acordo com as situações do presente de quem escreve. Entre outubro de 1957 e outubro de 1958, Alceu Amoroso Lima publicou em forma de artigos de jornal algumas notas sobre o que representou o Centro Dom Vital para as décadas de 1920 a 1940 e tais textos são relevantes por diversos motivos. O primeiro deles é porque se trata de sua primeira tentativa de estabelecer um sentido para essa quadra histórica. Em segundo lugar, ela serve também para pensar o período no qual elas são escritas, isto é, na possibilidade de compreender a situação do Centro na década de 1950 a partir delas. Por um lado ou por outro, a passagem seguinte é bastante significativa:

\footnotetext{
${ }^{18}$ Este último convite está registrado em carta de 28/10/1939, depositada no CPDOC-FGV.

19 A isso some-se a criação de diversas universidades católicas espalhadas país, fortes concorrentes do Centro quanto ao direito de servirem como fornecedores do discurso da Igreja.
} 
A nova geração começava a surgir marcada pelo sinal de Roma ou de Moscou (...) aquela coincidência, em 1922, da fundação do Partido Comunista Brasileiro e da fundação do Centro Dom Vital passava a revelar o seu sentido profundo, de modo que o choque, nas escolas, entre comunistas e aucistas, antes da explosão de 30 e sobretudo de 35, é que caracterizou esse ano de 1929 e a primeira irradiação do Centro Dom Vital ${ }^{20}$.

No início desta Introdução foi mencionada a construção da imagem do vitalista como um soldado da fé. A citação acima justifica a segunda parte do título da tese “entre Roma e Moscou”, porque são estas as duas possibilidades de inserção na cena intelectual: ao lado dos católicos (Roma) ou dos comunistas (Moscou). O dilema entre Roma ou Moscou seria expresso por diversas vezes ao longo da década de $1930^{21}$, durante a qual a polarização entre direita e esquerda alcançou seu paroxismo na cena política nacional.

O testemunho de Alceu possui o mérito de apresentar, apesar da distância de três décadas em relação ao período, um elemento fundamental: a divisão entre os grupos a disputar a primazia da cena intelectual carioca. Católicos e comunistas representariam duas estruturas paralelas de formação do intelectual, reprodução das atividades intelectuais e consagração de modelos a imitar. Eles foram materializados na existência de uma imprensa própria, um grupo de recrutamento na juventude, e a rede de indicações profissionais que os contatos das duas redes poderiam estabelecer. Simultaneamente ao aparecimento do exército católico, certas organizações de esquerda (como o Partido Comunista e a Aliança Nacional Libertadora) conheceram seu ápice de

${ }^{20}$ LIMA, Alceu Amoroso. Notas para a História do Centro Dom Vital. (introd. e org por: Riolando Azzi). Rio de Janeiro: Educam/Paulinas, 2001, p. 94-95 (O livro traz a série de 12 artigos escritos por Amoroso Lima entre outubro de 1957 e 1958).

${ }^{21}$ Segue um exemplo do que se pretende dizer:

"Lógicos não são, porém, os que por medo repelem Moscou e insistem em não se aproximarem de Roma que é o seu verdadeiro e único antípoda. Os governos têm empregado contra a propagando sovietista apenas meios de combate temporais. Obcecados com o princípio da separação da Igreja e do Estado não têm cuidado do espiritual." Retirado de: BACKHEUSER, Everardo. Os dois pólos da terra: ensaio anti-bolchevista. A Ordem, Rio de Janeiro, ano XII, n. 15, p. 282, maio 1931. 
atuação. Embora o texto de Leôncio Rodrigues ${ }^{22}$ apresente algumas simplificações excessivas, ele permanece como uma das principais tentativas de associar a origem social dos comunistas e as teses defendidas por eles ao longo da década de 1930. Seu objetivo é comprovar que o partido "cresceu para cima", isto é, cooptou membros de uma classe média bem educada, mas desprovida de riqueza material em nível equivalente ao de sua formação. Também cooptou uma parte da aristocracia agrária decadente e em dificuldades para se adaptar ao mercado em crescente industrialização e urbanização do Brasil dos anos 1930.

À diferença dos vitalistas, no entanto, a inclusão no partido representava uma dedicação exclusiva a um projeto político que comprometia a empregabilidade de seus militantes, levando-os ao esgotamento físico e psicológico depois de poucos anos. Por este motivo, a escolha entre católicos e comunistas poderia provocar consequências sérias no destino profissional imediato, como é possível depreender do relativo sucesso profissional dos vitalistas durante os anos 1930, em comparação com a pouca repercussão dos militantes de esquerda na mesma época, e seu sucesso depois do abandono do partido ${ }^{23}$. Além disso, há uma importante diferença dos militares, que tiveram grande participação nos diferentes comandos comunistas, mas não entre os católicos.

Outro elemento decisivo na concentração da atividade intelectual nestes dois polos é a quase inexistência de universidades, institutos de pesquisa, etc. capazes de contrabalancear por sua força o peso das burocracias (partidária ou religiosa) e sua capacidade de encontrar recompensas materiais e simbólicas a quem fizesse parte delas.

A força de tais burocracias se torna ainda maior quando comparada à fragilidade institucional de outras alternativas. O funcionalismo público, por exemplo, passou por

${ }^{22}$ RODRIGUES, Leôncio Martins. Capítulo VIII - O PCB: os dirigentes e a organização. In: FAUSTO, Boris. História Geral da Civilização Brasileira: o Brasil Republicano. Rio de Janeiro: Bertrand Brasil, 2007, v. 10 - Sociedade e política (1930-1964), p. 431-532.

${ }^{23}$ Corifeu de Azevedo Marques foi, posteriormente, Diretor de um jornal dos Diários Associados, tal como Hermínio Sachetta, que foi Redator e Diretor de vários jornais importantes de São Paulo; Rubem Braga e Rachel de Queiroz transformaram-se em escritores de renome. Outros obtiveram posições importantes no aparelho estatal: Francisco Mangabeira foi Presidente da Petrobras; Soares Cabello obteve um alto posto no funcionalismo federal; Cascardo, em 1967, obteve o posto de Almirante; Josias Carneiro Leão foi Embaixador do Brasil; Carlos Lacerda, jornalista, foi depois político e Governador do Rio de Janeiro. Cf: RODRIGUES, Leôncio. Obra citada, p. 478 
diversas crises. O golpe de outubro de 1930 ocasionou a primeira delas, na medida em que interrompeu a ascensão na carreira de diversos representantes das dinastias que ocuparam cargos públicos durante toda a Primeira República. Mesmo a criação dos novos ministérios por Vargas, ele próprio uma figura provisória naquele momento, tentou acomodar as forças políticas sem alterar as relações de força estabelecidas.

Deste modo, os funcionários dos Ministérios do Trabalho se dividiam entre "políticos" e "revolucionários", estes desejando uma atuação mais próxima das aspirações dos trabalhadores enquanto aqueles concebiam o órgão como um controlador dos sindicatos. (GOMES, 1987) No Ministério da Educação, Francisco Campos procurava conciliar membros das duas tendências pedagógicas predominantes no período: católicos e escolanovistas. Outras formas de burocracia governamental que pudessem abrigar uma alternativa política e cultural, como as municipais e estaduais, também não se mostraram viáveis, exceção notável feita a São Paulo. A formação das universidades se deu dentro de um processo turbulento, de ataques constantes à independência do corpo docente, do qual também fez parte Amoroso Lima.

Entre os anos de 1932 e 1938, a presença intensa do integralismo permitiu aos intelectuais vislumbrar uma alternativa que era ao mesmo tempo uma continuidade do Centro. Boa parte dos colaboradores desta imprensa foi também contribuinte em $A$ Ordem. Além disso, o movimento se beneficiou de sua condição ambígua de apoio e concorrente do regime varguista estabelecido, pois a ênfase na importância de obediência à autoridade se coadunava com um discurso de ênfase no objetivo de tomar o poder. Esta perigosa volatilidade da ideia de a quem prestar obediência chamou a atenção de Vargas, responsável pelo fechamento definitivo do partido em 1938. Rejeitadas as outras opções, resta, no entanto, uma pergunta importante: como o Centro logrou atiçar a curiosidade de tantos membros da elite carioca? Como resultou em uma corrente de esforços notável em termos de produção de escritos e mobilização de letrados?

Estas são perguntas pertinentes na medida em que se tratava de um grupo cuja porta de ingresso era estreita e a entrada de cada membro tendia fortemente a reproduzir os laços estabelecidos anteriormente. Seu sucesso se justifica pelo entrelaçamento de disposições individuais para o trabalho em favor de uma causa e uma instituição como a Igreja, que precisava de agentes para vocalizar suas pretensões, mas não contava com 
profissionais bem formados para esta finalidade ${ }^{24}$. A vantagem comparativa da Igreja em relação aos comunistas era a possibilidade de incluir a coparticipação com outros empregadores de mão-de-obra intelectual, tais como os partidos políticos. Também em consequência disso é que as trajetórias de aucistas tendem a demonstrar um rendimento maior em cargos do que os comunistas.

Partindo de tais considerações, restará ainda por compreender ao longo do trabalho dois aspectos importantes ligados ao Centro: 1) o papel dos intelectuais na implementação das diretrizes de Dom Leme, de modo a explicar o porquê de o Centro Dom Vital ter atingido o grau de ativismo que ele obteve; e 2) os investimentos materiais e simbólicos destes intelectuais na sua carreira, em conexão com essa instituição. Além das justificativas apresentadas para as condições de convergência entre os membros do grupo, há razões afetivas para explicar a adesão. $\mathrm{O}$ depoimento de Laurita Raja Gabaglia ${ }^{25}$ reforça o aspecto da amizade como essencial ao grupo:

O Centro D. Vital congregou um punhado de amigos e amigos-deamigos, pois cada um vinha trazendo os do seu grupo para aquele foco de irradiação espiritual. Aos fundadores juntaram-se logo, entre outros, Vilhena de Morais e Jônathas Serrano, expressamente enviados por D. Sebastião. ${ }^{26}$

A importância da amizade na formação do grupo remete à análise de Raymond Williams sobre o círculo de Bloomsbury ${ }^{27}$, um núcleo de escritores, poetas e acadêmicos da Inglaterra no século XX, no qual também era considerável a importância

${ }^{24}$ Este argumento é visivelmente oriundo das considerações de Sergio Miceli a respeito dos meios de cooptação da elite eclesiástica na Primeira República e do grupo de intelectuais deserdados de suas carreiras promissoras com o advento da Revolução de 1930. A este respeito, conferir, de autoria de Sergio Miceli: A elite eclesiástica brasileira e Intelectuais à Brasileira.

${ }^{25}$ Laurita Raja Gabaglia ficou também conhecida pelo nome de Irmã Maria Regina do Santo Rosário, adotado após sua admissão à vida religiosa. Era filha de Epitácio Pessoa e escreveu uma biografia sobre o pai antes de escrever a obra sobre o Cardeal Leme. Fazia, portanto, parte do mesmo círculo de poder do qual saíram os dois biografados. Em meio ao incontornável tom de celebração que a obra atinge, há algumas páginas primorosas sobre os conflitos que marcam a ascensão de Dom Leme à figura de representante máximo da hierarquia católica nacional. $\mathrm{O}$ relacionamento de Dom Leme com seu antecessor, o cardeal Arcoverde, com as demonstrações públicas de falta de apreço deste com relação àquele, estabelecem um interessante paralelo com a disputa entre as devoções laicais antigas e aquela proporcionada pelo Centro Dom Vital. Estes são os conflitos que marcam o processo de consolidação institucional da Igreja, tal como descrito por Sergio Miceli em Elite eclesiástica brasileira.

${ }^{26}$ GABAGLIA, Laurita Pessôa Raja. O Cardeal Leme. Rio de Janeiro, Livraria José Olympio Editora, 1962, p. 182.

${ }^{27}$ WILLIAMS, Raymond. "O círculo de Bloomsbury. In: Cultura e materialismo. São Paulo: Unesp, 2005, p. 201-230. 
dos elementos afetivos na configuração de um espaço de sociabilidade. Para mergulhar na vivência das afetividades no interior deste grupo, Williams conta com a imensa vantagem de possuir relatos a respeito do grupo, memórias sobre seus membros e biografias. Para compreender a dinâmica afetiva interna ao grupo, leva em conta elementos (a afetividade, por exemplo) sem nexos causais diretos com a intervenção do personagem em questão na vida pública.

Williams não deixa de reconhecer a importância do fato de todos pertencerem à mesma elite social para que haja comunhão entre eles, mas apenas isso não seria capaz de explicar os motivos pelos quais os membros do círculo de Bloomsbury encontravam prazer na convivência. Transferindo para o objeto em investigação: a origem social do grupo, marcante para a formação e o destino profissional dos seus membros, é entretanto insuficiente para explicar por si só qual seria a "magia" que os levou a atuarem unidos no Centro. Dito de outra forma, o fato de os vitalistas pertencerem a um mesmo estrato social, localizado em posição de destaque na hierarquia da sociedade, não dá conta de explicar as afinidades de pensamento e de atitude aglutinadoras do grupo.

As demonstrações de apego à militância se materializavam em momentos específicos, como a "Páscoa dos Intelectuais". Ela era organizada a cada ano pela própria Arquidiocese com bastante antecedência e consistia em uma lista que circulava pelas faculdades e centros culturais da cidade durante o período, oferecendo a quem desejasse participar dela a possibilidade de se inscrever. Os primeiros nomes eram cuidadosamente escolhidos para transmitir relevância ao evento: a de 1934, por exemplo, vem encabeçada por ministros, deputados e senadores. A lista seguia então uma hierarquia bem determinada, incluindo os mais consagrados, seguidos de profissionais liberais e, por último, os universitários e secundaristas. A presença de ilustres da sociedade carioca conferia prestígio a todos que participassem da missa.

Havia, porém, outras modalidades de inserção, mais restritas, dos quais poderiam resultar amizades que renderiam convites para empregos e trabalhos em conjunto. As reuniões do Centro e os retiros promovidos por ocasião do Carnaval eram provas de dedicação reservadas a apenas alguns poucos, de modo a destaca-los do restante do grupo. As reuniões ocorriam uma vez por semana, contavam com palestras (muitas delas proferidas por Leonel Franca), momentos de oração e apresentações de obras produzidas pelos próprios membros do Centro. Durante as reuniões, havia uma 
quebra de hierarquias materializada pela convivência entre clérigos e leigos, ou pelo topo da hierarquia do Centro com os jovens aucistas.

Os sinais visíveis deste fenômeno foram as inovações litúrgicas descritas por estes últimos, como o fato de os monges beneditinos rezarem a missa de frente para o público e conversarem com os fiéis durante a homilia. ${ }^{28}$ Os retiros também eram momentos de convivência com a cúpula, nos quais se forjavam laços de amizade que poderiam se reproduzir dentro e fora das instituições católicas. Por estas características, os retiros e as atividades do Centro Dom Vital serviram como espaços de formação de novos quadros da elite para conduzir o pensamento e a ação leiga no futuro.

Se para os leigos o Centro consistiu em uma oportunidade de exercer um novo papel na organização da Igreja, também se faz necessário compreender os motivos que levaram Dom Leme a permitir e até investir na formação de um grupo com essas características. A autora de sua biografia possuía uma hipótese: a escolha por contar com um grupo forte de leigos poderia ser explicada pela personalidade de Dom Leme, cuja abertura para a participação dos leigos no engrandecimento da Igreja encontrou respostas generosas. A explicação de Raja Gabaglia traz em si um alto grau de providencialismo implícito, como se coubesse a uma inteligência superior fazer unir a vontade dos leigos em ajudar com a disposição da hierarquia de aceitar esta ajuda. Outra limitação desta ideia é que ela não possibilita apreender as circunstâncias que tornaram possível a construção desta aliança ímpar na História da Igreja no Brasil. Não houve momentos anteriores ou posteriores a este no qual hierarquia e laicato tivessem trabalhado juntos de forma tão intensa e com tanta penetração nos meios oficiais. ${ }^{29}$

Em certa medida, isso é também resultado da falta de formação do clero nacional, problema do qual é possível ter uma ideia mais exata quando se nota a relativa

\footnotetext{
${ }^{28}$ A homilia é o momento da missa em que o padre se dirige aos fiéis, após ler alguns trechos da Bíblia, para lhes explicar o sentido das escrituras e fazer exortações. O hábito de rezar a missa de frente para o público foi instituído a partir do Concílio Vaticano II, cerca de trinta anos depois da vivência litúrgica do Centro.

${ }^{29}$ Não se trata aqui de relegar as importantíssimas experiências dos leigos nas décadas de 1960 (Ação Popular) ou 1970 e 1980 (Comunidades Ecleciais de Base) a um segundo plano, mas afirmar que elas possuem uma natureza distinta da analisada neste texto. As experiências citadas se organizaram à margem ou às vezes até contra a vontade da hierarquia, que titubeou entre a manifestação de apoio de alguns bispos e a rejeição (silenciosa ou aberta) da maioria. No caso do Centro dom Vital, a ação de leigos e clérigos se deu em um contexto de íntima colaboração e os resultados foram significativamente bons para ambos os lados. Dito isso, também não se pode negar o fato de que a ação do Centro teve um raio muito menor que estas organizações populares e a cooperação íntima entre leigos e clérigos era um meio de estes últimos exercerem seu poder de modo inconteste.
} 
escassez de bispos no período, dentre os quais um grupo ainda mais reduzido possuía alguma forma de especialização em sua instrução. Neste sentido, convém estabelecer pontos de comparação entre os dados disponíveis para aquele período e analisados por Sergio Miceli, com os trabalhos de Wheriston Neris e Ernest Seidl ${ }^{30}$, que fizeram um raio $\mathrm{X}$ da situação atual e encontraram diferenças importantes entre a elite episcopal da Primeira República e a atual.

Registra-se um período de estudos dos bispos mais prolongado atualmente, podendo chegar até ao doutorado, dentro do qual uma longa estadia em Roma pode fazer a diferença na carreira. Além disso, considera-se essencial possuir algum tempo de vida paroquial e uma passagem (como professou ou reitor) por alguma instituição de ensino (seminário ou escola/faculdade católica). Com todas essas exigências, a média de tempo entre a ordenação sacerdotal e a episcopal aumentou, assim como a idade média dos bispos.

Para desenvolver os aspectos aos quais se propõe, a tese se apresenta dividida em seis capítulos. Os dois primeiros se dedicam a oferecer um panorama geral do grupo a partir de dois ângulos complementares. O capítulo I versa sobre a bibliografia a respeito do tema, e demonstrará certos silêncios e ausências na literatura sobre a vida intelectual brasileira dos anos 1930 que podem ser preenchidos a partir de um estudo sobre o Centro Dom Vital. Além disso, projeta questões respondidas a partir do segundo capítulo, onde serão examinados detidamente os aspectos morfológicos do grupo e de sua produção literária. Ele trata mais a fundo as consequências das diferenças entre os vitalistas em relação ao acúmulo de sinais de distinção e o modo como isso reverbera em sua trajetória.

Os quatro últimos capítulos da tese se destinam à análise mais específica da atuação dos membros do Centro em searas específicas. No terceiro capítulo, será a vez de tratar da crítica literária, entendida em seu sentido mais amplo, pois foi através dela que os vitalistas se encontraram intelectualmente na revista A Ordem (1921) e frequentarem o Centro Dom Vital (1922).

\footnotetext{
${ }^{30}$ NERIS, Wheriston Silva \& SEIDL, Ernesto. "O Episcopado Brasileiro e o Espaço do Poder: transformações da alta esfera eclesiástica". [Apresentação de trabalho] Anais do $34^{\circ}$ Encontro Anual da ANPOCS, de 25 a 29 de outubro de 2010, Caxambu, MG. Disponível em: http://portal.anpocs.org/portal/index.php?option=com_docman\&task=doc_details\&gid=1463\&It $\underline{\text { emid }=350}$
} 
A partir destas experiências se constituiu a estratégia de luta do grupo, a começar pelas políticas públicas de educação em todos os seus níveis, tema do quarto capítulo. Em paralelo à proposta de ensino religioso para o ensino primário e secundário, os vitalistas formularam meios de incluir os assuntos teológicos no seio do domínio científico e despertaram grandes resistências por este motivo. O capítulo desenvolverá uma análise levando em conta não apenas os fatores estritamente acadêmicos do desenrolar desta luta e demonstrará como ela envolve uma disputa por cargos e prestígio.

Como o corolário da discussão sobre a melhor forma de produzir ciência, havia uma outra, sobre o modelo de intelectual e cientista. Novamente o peso da religião se faz sentir, junto aos condicionantes da tradição intelectual brasileira no período: dada a escassez de exemplos de intelectuais católicos com um bom trânsito entre o conjunto de letrados do período, os vitalistas se veem obrigados a recorrer frequentemente às mesmas figuras, inclusive ao fazer uso de um filósofo que nunca professou a fé católica, como foi o caso de Farias Brito. A inclusão de seu nome no panteão de autores se deu em razão de seu papel de formador de uma matriz filosófica oposta ao positivismo, na qual valorizou o papel da religião como uma continuação da reflexão filosófica.

Não obstante essas dificuldades práticas na sua realização, esta hagiografia preocupada em se adaptar aos problemas de seu tempo consagrou um tipo novo de santo, sintonizado com os problemas da polis e preocupado em recuperar o prestígio perdido pela religião. O problema da intervenção na política se torna, portanto, uma questão de dever religioso e as propostas e ações do grupo serão o tema do último capítulo, no qual também serão avaliadas as relações entre os eventos políticos conturbados do período e as opiniões expressas pelo grupo.

Em uma tese com tal amplitude temática, seria impossível deixar de assumir certos recortes. Entre os aspectos que não foram tratados por este texto, talvez o mais relevante seja uma comparação mais extensa com a "outra metade" da vida intelectual carioca dos anos 1930, isto é, com os comunistas. Ao longo do trabalho se avançam algumas considerações a este respeito, mas é forçoso reconhecer que uma comparação exaustiva seria matéria para uma outra tese, e investir largamente nesta saída aqui seria promover um paralelismo desequilibrado pela falta de pesquisa empírica em relação aos comunistas. Fica a sugestão para um trabalho futuro. 


\section{DESENVOLVIMENTO}




\section{Capítulo I: Delimitação do problema a partir da}

bibliografia

"Convém supor que há algo de incognoscível, mas não se deve colocar limite à sua busca" (Goethe apud Bourdieu, 1996) 
Na epígrafe, Bourdieu menciona Goethe para justificar sua pretensão de que todos os fenômenos sociais são passíveis de explicação sociológica. A frase constitui um excelente incentivo para um início de tese na qual se pretende responder, entre outras questões espinhosas, ao desafio de compreender um surto de conversões e uma nova forma de se identificar ao catolicismo, da qual faz parte a formação de um padrão de gosto artístico e ideologia política. Por este motivo, é necessário conhecer o que a bibliografia tem a dizer a esse respeito, a começar pela condição de atuação dos intelectuais nos anos 1930 .

As condições de atuação dos intelectuais na Primeira República e nos anos 1930 deu ensejo a diversos estudos, permitindo traçar o que seriam as linhas de força para uma interpretação mais geral sobre o período. Elias Thomé Saliba ${ }^{31}$ e Sergio Miceli ${ }^{32}$, por exemplo, possuem em comum a preocupação de mapear os dados sobre a circulação de livros, revistas, jornais e outras formas de impressos no período, de modo a configurar com maior precisão o impacto dessas publicações no interior da sociedade brasileira. Miceli e Saliba também levam em consideração os aspectos materiais e simbólicos na luta pela sobrevivência e pela consagração que pautam os investimentos dos escritores no período, entabulando um diálogo entre estes dados e a análise interna dos textos. Há uma correlação entre estes trabalhos e o de Heloísa Pontes (1995), cujo interesse reside no modo como a trajetória dos editores pode ajudar a entender a cena intelectual do período.

Seu estudo joga luz em certos aspectos da produção livresca do grupo em questão, como, por exemplo, a presença maciça de manuais didáticos e os de cunho histórico-biográfico entre o conjunto de livros vendidos, característica comum ao quadro geral dos produzidos pelos vitalistas. Por outro lado, outro grande gênero de sucesso no período, o romance, não teve nenhum grande representante do grupo. Isto pode ser explicado pela preocupação social que percorreu a maior parte da produção do período, frente ao caráter intimista do tipo de literatura valorizado pelos católicos. Entre

${ }^{31}$ SALIBA, Elias Thomé. Cultura: as apostas na República (parte 5). In: SCHWARCZ, Lilia Moritz. História do Brasil Nação (1808-2010). Rio de Janeiro: Objetiva, 2012. (Vol. 3: A abertura para o mundo 1889-1930), p. 239-294.

${ }^{32}$ Em seus dois livros "Poder, sexo e letras na República Velha" e "Intelectuais e classe dirigente no Brasil (1920-1945)", ambos reunidos na edição de 2001 de Intelectuais à brasileira. São Paulo: Companhia das Letras, 2003. 
os dois tipos de romance, o fosso de abordagens epistemológicas distintas: o romance social investe na leitura do mundo a partir de seus aspectos materiais, objetivos, enquanto o "romance da alma", ou intimista, mergulha nos estados de espírito, nos sentimentos e subjetividades.

A circulação de livros e impressos em geral possuía limites sociais bastante estreitos: levando-se em conta o país inteiro, apenas $15 \%$ das pessoas sabiam ler. Na capital federal, onde as condições eram um pouco melhores, esse número não chegava a metade da população. Mesmo assim, as primeiras décadas da República assistiram ao surgimento das revistas semanais ilustradas e a um período de pujança da imprensa diária, fazendo dela a principal fonte de emprego. Quase toda a literatura brasileira do período se iniciou no trabalho em jornais, enfrentando a pressão por escrever em prazo curto e sobre temas os mais diversos. Esta habilidade seria de grande uso para outros empregadores, como as Assembleias (estaduais e nacional) e os partidos republicanos, na qual estes intelectuais formariam um novo tipo de intelectual, o anatoliano:

Os integrantes desse grupo prefiguram um tipo novo de intelectual profissional, assalariado ou pequeno produtor independente, vivendo dos rendimentos que lhes propiciam as diversas modalidades de sua produção, desde a assessoria jurídica, as conferências, passando pelas colaborações na imprensa, até a participação nos acontecimentos mundanos e nas campanhas de mobilização em favor do serviço militar, da alfabetização, do ensino primário, etc. ${ }^{33}$

Antes de se especializar na defesa dos interesses católicos, Jackson de Figueiredo se encaixava perfeitamente neste papel, tendo se mobilizado em ligas patrióticas antilusitanas e publicado poesias ou ensaios de crítica literária favoráveis a alguns amigos. Não tendo se consagrado em nenhuma dessas frentes, seu nome ficou associado para a posteridade com a defesa do ponto de vista católico porque este foi, entre seus investimentos, aquele que surtiu mais efeito.

Nota-se neste período um crescimento do mercado editorial, amparado por edições baratas de livros com temas popularescos (romances para moças, livros obscenos, receitas de mandingas e remédios caseiros). Por sua temática e estilo, as produções dos vitalistas desde a década de 1920 se inserem nos debates que ocupam o proscênio intelectual do período: a desilusão com os rumos tomados pelo regime

\footnotetext{
${ }^{33}$ MICELI, Sérgio. Intelectuais à brasileira. São Paulo: Companhia das Letras, 2001, p. 54.
} 
republicano, do qual se esperavam soluções mais eficientes para arrancar o país de uma situação percebida como de atraso em relação aos outros países. Obras como as de Lima Barreto, João do Rio, Euclides da Cunha e Machado de Assis apontaram os desencontros entre a profissão de fé republicana de que todos os cidadãos seriam i guais perante a lei e as práticas, mantidas quando não aprofundadas, da lógica do apadrinhamento no recrutamento para funções públicas e do valor das relações pessoais que se sobrepõem ao tratamento impessoal.

Estas e outras questões giravam em torno do tema da identidade nacional, uma obsessão entre os intelectuais deste período. Ele ganhou novos contornos a partir do final da I Guerra Mundial, quando o restabelecimento das ligações entre Brasil e Europa intensificou o ingresso das vanguardas europeias no país por meio dos artistas. O choque entre uma realidade nacional em permanente ebulição e as ideias de transformação radical na política e nas artes foi um tema recorrente nos escritos do grupo.

Utilizando a divisão estabelecida por Saliba entre autores que preferiram uma pesquisa empírica mais complexa sobre a identidade nacional e outros que investiram mais pesadamente no sentido político que tal invenção poderia ter, os vitalistas ficaram mais próximos desta segunda forma de se compreender o nacional. Em seus escritos, assim como nos do movimento verde-amarelo, certos aspectos históricos são ignorados em benefício da construção de uma identidade católica. Na narração da história pelos católicos, por exemplo, a contribuição de negros e indígenas é largamente deixada de lado, sob a justificativa de que nenhum destes grupos representa o "autêntico" catolicismo que forma o país, como demonstram os manuais de História escritos por Jônathas Serrano.

O exemplo de Serrano é, sem dúvida, o mais radical neste sentido, mas poderia ser corroborado pelas considerações da Literatura Reacionária de Jackson de Figueiredo, que critica na obra de Afrânio Peixoto seus elementos racialistas de rebaixamento da qualidade do mestiço brasileiro. Admitir a existência de raças distintas de humanos seria para ele uma afronta à narrativa bíblica e à concepção católica de natureza humana, única e feita "à imagem e semelhança de Deus", nas palavras da narrativa bíblica do livro de Gênesis. Se houvesse algum fator degenerativo entre os homens, não caberia pensar que sua origem fosse biológica, mas cultural, isto é, religiosa. 
A convergência de pensamento, como a de Serrano e Figueiredo nesta passagem, tem levado os pesquisadores a privilegiar as características uniformes dentro do grupo. É o caso, por exemplo, do trabalho de Alexandre José Gonçalves Costa ${ }^{34}$, que opta pela leitura extensa do órgão oficial do Centro - a revista A Ordem - em busca das uniformidades entre as diversas opiniões expressas em suas páginas. Em uma pesquisa de fôlego que atravessa duas décadas com vistas a reconhecer a matriz teológicopolítica da revista, Costa faz um excelente mapeamento dos temas trabalhados por ela, mas deixa de investir em seu diálogo com outros autores brasileiros.

A Ordem foi objeto de um outro estudo, da autoria de Cândido Moreira Rodrigues $^{35}$, com um recorte reduzido a uma década, o qual lhe permitiu tratar de modo mais detido das múltiplas vertentes do conservadorismo presentes na revista, divididas em político-ideológicas, de um lado, e teórico-filosóficas, de outro. Após a análise destas matrizes, Rodrigues mergulha em considerações sobre o papel do intelectual no regime varguista, para chegar à conclusão de que os colunistas de Ordem não foram cooptados pelo Estado, mas atuaram no interior dele como emissários de outro projeto, o da hierarquia católica. Para provar sua hipótese, apresenta um capítulo final de análise mais detalhada da revista, a partir do qual constrói uma narrativa das alterações de tendência política pelas quais ela passou entre 1934 e 1945. O livro traz, em suma, um recorrido amplo e abrangente da revista para este período.

Não obstante as diferenças de abordagem destes autores, ambos privilegiam uma História Intelectual sob a perspectiva da análise interna aos textos, associada à procura por suas "influências", entendendo-se por tal os modelos de pensamento incorporados pelos autores da revista. Tais modelos são importados da Europa: no caso do Cândido Rodrigues as matrizes intelectuais são os contra-revolucionários do século XIX na França (Joseph de Maistre, De Bonald) e na Inglaterra (Burke), enquanto Alexandre

\footnotetext{
${ }^{34}$ COSTA, Alexandre José Gonçalves. Teologia e política: a ordem e a atualização do discurso político-social católico no Brasil, 1931-1958. 2010. 262f. Tese. (Doutorado em História) Instituto de Filosofia e Ciências Humanas, Universidade Estadual de Campinas - Unicamp, Campinas, 2010.

35 RODRIGUES, Cândido Moreira. A Ordem: uma revista de intelectuais católicos. Belo Horizonte: Autêntica, 2006.
} 
Costa privilegia o maritainismo ${ }^{36}$. Em sua tese de doutoramento, Rodrigues matiza essa divisão ao se debruçar sobre o diálogo entre Maritain e Tristão de Athayde ${ }^{37}$.

Ainda que estes dois autores possam usar em seu benefício o fato de que a revista se declara a todo momento fora e acima da política partidária, a presente tese quer relativizar as conclusões apresentadas, ao inserir novos pontos de vista na questão. A própria relevância de Maritain em toda a América Latina só se torna plenamente inteligível a partir do uso político de seus escritos para prestigiar a Democracia Cristã local. Para descrever sua fortuna crítica do filósofo de Meudon, Compagnon (2005) utilizou a figura de alguém que se torna um modelo para a América Latina "contra a própria vontade", na medida em que seus escritos assumem sentidos, nos países latinoamericanos, inimagináveis tendo-se em vista apenas o modo como se deu sua recepção na Europa. No Brasil, ele foi durante a década de 1930 o nome mais evocado no ataque ao controle do Estado sobre as atividades sociais, e assumiu o papel de fiador involuntário da posição católica de aceitação dos comunistas no jogo político no imediato pós-Estado Novo.

Com a instalação no país do movimento Economia e Humanismo, do padre Lebret, Maritain perde o posto de voz mais progressista, e sua intransigência frente à realidade em constante mutação modifica a visão que os brasileiros têm a seu respeito. Ele é progressivamente interpretado como um autor da direita católica. Outros grupos franceses, como o da revista $E s p r i t^{38}$, fornecem referenciais para a guinada à esquerda da Igreja brasileira.

\footnotetext{
${ }^{36}$ Jacques Maritain foi um filósofo francês que se tornou o nome mais saliente no catolicismo francês já a partir da década de 1920, com obras como Antimoderne (1921). Nesta como nas demais obras da década de 1920, Maritain assume uma abordagem de rompimento com os valores democrática que seria revista em obras posteriores, como Cristianismo e democracia (1945).

${ }^{37}$ RODRIGUES, Cândido Moreira. Aproximação e conversões: o intelectual Alceu Amoroso Lima no Brasil dos anos 1928 - 1946. São Paulo: Editora Alameda, 2012.

${ }^{38}$ Segundo Michel Winock, o grupo formado em torno da revista Esprit pode ser compreendido como a resposta a três crises simultâneas na sociedade francesa: a crise do esforço da I Guerra Mundial e da depressão econômica seguinte; a crise social advinda do avanço das organizações comunistas sobre as organizações operárias francesas, e a crise da Igreja e de seus fiéis, sem lugar para a reflexão religiosa em uma sociedade na qual a Igreja havia perdido as vias de participação na discussão pública sobre educação, moral, costumes familiares. A respeito do papel do grupo na oposição à Action Française durante o entreguerras e, a partir de 1940, na Resistência Francesa, consultar:
} 
Se por um lado esta pequena digressão permite enxergar a importância de Maritain no contexto latino-americano, ela dá ensejo à conclusão de que só é possível compreender os escritos do período se houver o exame de como eles alimentaram as pretensões do grupo a conquistar o direito de determinar as políticas públicas. Apenas a referência aos nomes estrangeiros evocados como bases teóricas do grupo não dá conta de explicar todo o complexo jogo de forças atuantes na moldagem dos discursos dos vitalistas no período em questão.

Ao enfrentar estas questões, a pesquisa pretende filiar-se a uma abordagem sobre intelectuais consagrada por Pierre Bourdieu. Eles construíram um tipo de sociologia capaz de compreender os sujeitos históricos como o produto de uma trajetória social, ou seja, do conjunto de capitais (simbólicos ou materiais) acumulados ao longo da vida. Dada a natureza necessariamente escassa de tais capitais, eles se tornam marcas de distinção a diferenciar aqueles que o possuem dos que não o têm. Portanto, e com uma certa dose de simplificação no raciocínio, uma das formas de compreender qualquer atividade social é em termos de uma disputa por estes sinais de diferenciação. Ao mesmo tempo em que a pesquisa adota este aspecto como um prisma teórico relevante, toma-se a precaução de evitar alguns equívocos teóricos relevantes. Um deles consistiria em supor sujeitos dotados de total inteligibilidade de suas ações e de plena racionalidade nos seus atos, com a clareza do capital a obter e conscientes em todos os momentos de qual a melhor estratégia para atingi-lo.

Neste sentido, será útil pensar na ação dos sujeitos a partir da ideia de habitus ${ }^{39}$, entendido como a intersecção de uma prática social, sempre improvisada porque imprevisível, e um conjunto de características acumuladas ao longo da passagem do sujeito por instituições determinantes que o ajudam a se situar socialmente (a família, a

WINOCK, Michel. Esprit: Des intellectuels dans la cité 1930-1950. Paris: Éditions du Seiul, 1995.

39 A esse respeito, conferir a coletânea Bourdieu - a critical perspective. Há diferenças importantes entre o modo como Bourdieu foi introduzido no Brasil e nos países de língua saxônica, onde suas obras foram traduzidas de forma mais tarde e apresentaram um certo ruído em sua leitura, ocasionado pelo desconhecimento dos leitores em inglês das questões pertinentes ao universo da sociologia na França. Não obstante, consideramos sua leitura válida para situar a obra de Bourdieu no Brasil porque ela permite pensar nos compromissos assumidos a partir de seu uso.

CALHOUN, Craig; LiPUMA, Edward \& POSTONE, Moishe. Bourdieu: a critical perspective. Cambridge: Polity Press, 1993. 
escola, o círculo de amigos e, no caso específico deste grupo, certamente também a Igreja). Este é um conceito rico de possibilidades, especialmente em um meio de produção de explicações sempre amparadas na ideia de transcendência e de total liberdade criativa dos sujeitos. A frequência a um grupo de natureza religiosa leva seus membros por vezes a acreditarem que estão ali por uma vontade superior, que controla suas vidas. Mesmo quando não pensam assim, podem possuir a ilusão de que o meio em que atuam é um livro aberto, que poderia ser escrito da forma como bem entendessem.

No ambiente sob a análise da presente tese, há diversos espaços sociais em vias de consolidação àqueles que desejassem obter a aceitação como intelectuais de cepa: as nascentes universidades, a imprensa e o mercado editorial em expansão, mas também a Igreja e seus projetos de ocupação destes espaços. Por isso, um dos motivos pelos quais a sociologia de Bourdieu pode ser fecunda aqui é pensar na relação destes sujeitos com as instituições pelas quais eles atuam. Ela está constituída por disputas intrainstitucionais e interinstitucionais, pois o estoque de alternativas de retribuições simbólicas e materiais disponíveis é limitado pela quantidade de mediadores aceitos como tal. No Brasil dos anos 1930, a luta por definir quais grupos se ocupariam dos novos postos de trabalho criados em torno da expansão da rede de ensino está prenhe de resultados sobre a definição de qual tipo de ciência seria considerada válida. O inverso também é verdadeiro.

Em meio a essa eterna disputa entre os atores, ganha sentido especial a precaução de Bourdieu em relação ao risco da "ilusão biográfica", isto é, de pensar os sujeitos como dotados de uma coerência interna que se perpetua por toda a sua vida, quando o mais correto seria dizer que eles se modificam ao longo do tempo em vista das movimentações internas do sistema de atuação. As alterações no panorama cultural exigiriam uma readaptação das leituras que o grupo produziu entre as décadas de 1920 e 1940. Trajetórias improváveis, como a de Amoroso Lima ou Leonel Franca, que passaram do flerte com o integralismo nos anos 1930 para a defesa da liberdade de expressão para os comunistas nos anos 1940, só podem ser compreendidas tendo em vista os debates nos quais estes autores se inseriram e as diferenças significativas entre as duas décadas.

Na primeira delas, o comunismo - ou o que era compreendido como tal apresenta-se como um polo importante na definição do panorama cultural e político brasileiro. Não se trata de afirmar que todos os rotulados de comunistas eram de fato 
partidários dessa ideologia; pelo contrário, a acusação de ser ou não comunista poderia ser considerado como o motor da disputa em diversos espaços institucionais relevantes para a cena cultural da cidade do Rio de Janeiro e do país. Na Faculdade do Rio de Janeiro, Amoroso Lima reputou a derrota nos dois concursos que disputou ao fato de ter enfrentado concorrentes "comunistas" frente a bancas examinadoras compostas por "comunistas" 40 ; no Ministério da Educação, cada posto entregue ao grupo dos escolanovistas era uma vaga entregue aos "comunistas" e contra os católicos.

Dada a natureza do objeto deste estudo, outras sociologias próximas à de Bourdieu em seu tema de estudo, mas com distintas implicações metodológicas, poderia ser de interesse para a pesquisa. Uma delas é a de Howard Becker ${ }^{41}$, com sua definição do que é arte e de quais os tipos de relação que o produtor de obras de arte pode nutrir com ela. Seu argumento central consiste em pensa-la como um "mundo" à parte, isto é, como uma atividade social relativamente autônoma em relação às demais, com definições propositalmente tênues em sua definição, a ponto de permitir pensar em pessoas que fazem parte deste universo mesmo sem tomarem consciência do fato. (Este seria o caso dos produtores de bens de artesanato ou daqueles que desempenham uma atividade tradicional em suas comunidades, sem se darem conta de que o resultado de seu trabalho poderia ser valorado como um trabalho artístico.)

Apesar de Becker se aproximar de Bourdieu em sua definição de arte como um campo autônomo de atividade, não discute a fundo quais são as instâncias consagradores das definições do que pode ser considerado artístico e ignora o fato de que elas são alvo de constantes disputas, tendo em vista a valoração positiva que pode ter um objeto considerado artístico frente a outro que não o é, ou de um tipo de arte considerado mais nobre do que outro. No caso dos vitalistas, um argumento que invalida tal raciocínio é pensar que sua integração em uma instituição da natureza do centro implica no domínio das regras mínimas sobre o que significa atuar neste círculo de intelectuais, com suas regras e hierarquias.

Além disso, ao publicar artigos de jornal e livros eles possuem pelo menos uma expectativa de qual deve ser a reação do mercado editorial, da imprensa e da opinião

\footnotetext{
${ }^{40} \mathrm{O}$ uso do termo é feito entre aspas porque ele reproduz as declarações do próprio Amoroso Lima e do sentido político que ela tem.

${ }^{41}$ BECKER, Howard. Los mundos del arte: sociología del trabajo artístico. Bernal: Universidad Nacional de Quilmes, 2008.
} 
pública em geral. Com isso não se pretende, contudo, afirmar que todos os vitalistas estariam plenamente conscientes dos cálculos de sua atuação no Centro e dos benefícios que ela poderia trazer, mas negar que fosse possível manter uma postura inocente do sentido social de suas práticas.

Outro ponto de partida para pensar a sociologia dos intelectuais é a obra de Bernard Lahire ${ }^{42}$. A cena literária francesa por ele estudada guarda certa semelhança com o ambiente carioca dos anos 1930, por exemplo, no grau elevado de indeterminação das instâncias que poderiam consagrar um autor. Não obstante os esforços de Enio Passiani ${ }^{43}$ em afirmar a existência no Brasil dos anos 1920 de um público leitor suficientemente amplo para atuar como fator determinante para a redação e circulação de novos textos, Simone Silva ${ }^{44}$ demonstrou que a consagração literária dependia essencialmente da roda de amigos e dos contatos que essas rodas pudessem ter com os editores e críticos de jornal. A noção de sucesso estava, portanto, atrelada a uma profusão de bens simbólicos não forçosamente relacionados ao retorno financeiro propiciado por tais livros.

Isso impediria uma profissionalização da atividade literária, da qual a maior parte não visava o retorno financeiro regularmente. Neste quesito, a vida literária francesa descrita por Lahire é muito semelhante ao que se passa no Rio de Janeiro, especialmente antes da emergência da José Olympio como casa editora. Lahire apresenta a trajetória de vários autores, atento a dados precisos: o tempo entre a publicação das obras, as editoras pelas quais são publicadas e os prêmios obtidos. Sua conclusão é de que não enxergam sua atividade como uma profissão, com a qual estivessem ligados por uma rotina. Eles não podem extrair dela sua remuneração quotidiana e não estão sujeitos a regras estritas de entrada - um prêmio literário não serve de gabarito para as obras seguintes - e nem de saída. Não há fronteira definitiva que separe os que estão dentro dos que estão fora do circuito e a maioria dos escritores tem um ritmo intermitente na produção, podendo passar diversos anos sem publicar.

${ }^{42}$ LAHIRE, Bernard. La condition littéraire: la double vie des écrivains. Paris: Édition La Découverte, 2006.

${ }^{43}$ PASSIANI, Enio. Na trilha do Jeca: Monteiro Lobato o público leitor e a formação do campo literário no Brasil. Sociologias, Porto Alegre, ano 4, n. 7, jan/jun 2002, p. 254-270.

${ }^{44}$ SILVA, Simone. As rodas literárias no Brasil nas décadas de 1920-30: troca e obrigações no mundo do livro. Latitude, v. 2, n. 2, p.182-210, 2008. 
Por todos esses motivos, Lahire considera difícil aplicar a ideia de uma crença comum para essa população, cujos contornos permaneceriam incertos. Logo, as constrições internas ao ambiente possuiriam uma força relativa, pois os atores poderiam a qualquer momento abandonar as pretensões literárias. Em contraponto, uma vez que decidam participar do jogo, as regras deveriam ser seguidas à risca. Não obstante os paralelos com a situação em tela, há pontos da argumentação da Lahire para os quais a transposição para o caso brasileiro resulta problemática. É o caso de sua negação da validade da ideia de illusio, tal como pensada por Bourdieu, pois o fato de que nem todos quisessem entrar no jogo não invalidaria a necessidade de compreender o que leva alguns a ingressarem neste grupo de crença compartilhada.

No Rio de Janeiro dos anos 1920, a illusio não apenas existe como se materializa em algumas instituições, como a Academia Brasileira de Letras. Instituição incontornável para simpatizantes e inimigos, os critérios de seleção dos imortais também entram em discussão e a predominância da prosa realista e da poesia parnasiana é contestada no discurso de Graça Aranha - com a audiência de Alceu. Mas a ABL não era a única conexão com os circuitos intelectuais europeus. Cândido acrescenta alguns dados a este contexto:

As tensões da Europa repercutiram ponderavelmente aqui. Não mais como transposição, mas como manifestação de uma solidariedade cultural intensificada depois da Primeira Guerra Mundial e do nosso progresso econômico. Direita e esquerda política refletindo na literatura; populismo literário e problemas psicológicos; socialismo e neotomismo; Surrealismo e Neo-realismo; laicismo e arregimentação católica; libertação nos costumes, formação da opinião política; eis alguns traços marcados e frequentemente contraditórios do decênio de 1930, assinalando, quer a projeção estética e ideológica do Modernismo, quer a reação do Espiritualismo literário e ideológico. ${ }^{45}$

As indicações de Cândido remetem à integração no âmbito mundial das disputas centrais no Rio entre os anos 1920 e 1940. Um pouco anterior a isso, entre 1900 e 1920, registrou-se um revigoramento do prestígio intelectual da Igreja em todo o âmbito ocidental a partir de uma retomada dos escritos de Tomás de Aquino. Não por acaso, este período assistiu a um surto de conversões ${ }^{46}$ de diversos intelectuais franceses (Jean

\footnotetext{
${ }^{45}$ CANDIDO, Antonio. Literatura e sociedade. Rio de Janeiro: Ouro sobre azul, 2006, p. 132.

${ }^{46} \mathrm{O}$ uso do termo não pretende reduzi-lo ao sentido estrito da volta às práticas piedosas, como foi o caso de Maritain. Ele pode representar uma mudança de direção na preocupação e na
} 
Cocteau, Jacques Maritain, Henri Bergson), ingleses (Chesterton), entre outros. A corrente espiritualista receberia outro reforço de meados da década de 1930 em diante, com o triunfo da direita à qual estava ideologicamente aliada no cenário político local. Uma série de romances, como os de Cornélio Penna ou Lúcio Cardoso, a poesia de Augusto Frederico Schmidt e os ensaios de Amoroso Lima marcam o predomínio ideológico claro da Igreja. A poesia se afasta definitivamente dos experimentalismos exacerbados da primeira fase do modernismo; os romances fazem a crítica do neorrealismo e mergulham em temas mais intimistas. A compreensão dessa vitória momentânea no terreno intelectual - para a qual muito contribuíram os vitalistas indica a existência de mecanismos a reger a produção e a consagração de certas obras, em detrimento de outras.

As observações de Cândido a respeito das ligações existentes entre a situação política e a produção literária também se revelam úteis para compreender, de modo mais geral, os desafios enfrentados pelo catolicismo em países como o Brasil e a Argentina. A república platina passou por um processo semelhante de reorganização institucional com a centralização do controle institucional transferido para Roma, e, em contraponto, a atração de leigos para diversas iniciativas intelectuais claramente apologéticas ${ }^{47}$. Essa defesa não se deu exclusivamente dentro do terreno político, como mostra a farta rede de publicações ligadas a uma preocupação religiosa.

A primeira destas publicações chamou-se América Latina e circulou entre agosto de 1919 e fevereiro de 1920, sob a coordenação de Andrade Muricy. Nesta revista Jackson de Figueiredo publicou em fascículos sua obra sobre Pascal ${ }^{48}$. Segundo Angela de Castro Gomes ${ }^{49}$, a experiência de América Latina foi primordial para Jackson Figueiredo pensar na organização de uma revista própria, sonho concretizado com $A$ Ordem. Antes dela porém veio Festa, periódico de importância fundamental para a configuração da cena carioca onde atuariam os membros do Centro Dom Vital, nas palavras de Ângela de Castro Gomes:

temática da prática reflexiva destes intelectuais e, principalmente, na alteração que eles ajudam a provocar em toda a cena onde atuam. Em todo caso, representa uma retomada da herança apologética (traduzível pelo interesse nos doutores da Igreja ou na busca por uma transcendência) como pauta da discussão.

47 FAUSTO, Boris; DEVOTO, Fernando. Brasil e Argentina: um ensaio de história comparada. São Paulo: Ed. 34, 2005.

${ }^{48}$ FIGUEIREDO, Jackson. Pascal e a inquietação moderna. Rio de Janeiro/Lisboa. Centro D. Vital/Anuário do Brasil/Renascença Portuguesa, 1922.

${ }^{49}$ GOMES, Angela de Castro. Essa gente do Rio... Rio de Janeiro: FGV, 1999. 
O Rio de Janeiro dos inícios do século XX torna-se uma cidade importante para a montagem de uma rede intelectual que se reconhece como pertencente a uma tradição simbolista. Essa tradição-ao mesmo tempo cômica, satírica, mística e espiritualista-não pode ser certamente associada de forma direta ao boom de militância católica que começava a eclodir em inícios da década de 1920. Entretanto, seria impossível não assinalar a convergência, bem como os laços que passam a unir as trajetórias de certos intelectuais simbolistas e de algumas das mais importantes lideranças leigas da militância católica de então, como é o caso de Jackson de Figueiredo. ${ }^{50}$

Festa apresenta outro jeito de ser modernista, sem a mesma necessidade de escandalizar dos de São Paulo, mas ainda assim aproveitando os tempos de liberdade de experimentar. A estratégia do grupo não passou desapercebida dos atores principais desta cena, como Mário de Andrade, que ironiza o fato de o grupo preparar sua armadura de combate mas nunca tomar a linha de frente, como fizeram os modernistas de São Paulo. Experiências como as de Festa propiciaram a formação do Centro Dom Vital.

Estas iniciativas são o resultado do rearmamento da Igreja (MICELI, 2001; 2009), que corresponde ao processo de estadualização das alianças, isto é, na capacidade da instituição em se refazer após cessar o apoio material proporcionado pelo Império. As elites locais forneceram ajuda financeira e mão de obra qualificada, aproveitada para a indicação de bispados. Ela se vê fortalecida após o rearmamento e, por conseguinte, constrói uma nova relação entre a hierarquia e os leigos. Na medida em que o clero se apresenta capaz de exigir do regime republicano o atendimento de demandas cada vez maiores, sentem a necessidade de professores, escritores, jornalistas, burocratas da educação (entre outras opções) cujos veios de atuação se darão na defesa de tais interesses.

Este processo se insere no debate sobre o papel do intelectual no ocaso da Primeira República e durante o governo de Vargas, que gira em torno de determinar se os intelectuais são cooptados pelo Estado no interior de um projeto político préexistente ou participam de forma ativa deste projeto. Em acréscimo a esta primeira questão, existem outras ligadas ao tamanho da participação da Igreja neste processo de cooptação/participação dos intelectuais. Em complemento, deve-se levar em conta as

\footnotetext{
${ }^{50}$ GOMES, Angela de Castro. Os intelectuais cariocas, o modernismo e o nacionalismo: o caso de Festa. In: Luso-Brazilian Review, v. 41, n. 1, 2004, p. 80-106.
} 
complexas relações entre a posição social de origem dos indivíduos a ocupar os postos de defesa dessas instituições e o tipo de ação que tomam, quando oficialmente pertencentes a elas.

No estado atual do debate, existe o lado daqueles que, como Sergio Miceli (e Monica Velloso, Lúcia Lippi de Oliveira, entre outros) tendem a reforçar em sua explicação a força do Estado na cooptação. A ênfase desta primeira versão recai sobre a as diferenças de destino entre os escritores, relacionadas ao nível de reconhecimento fora da função estatal. Por exemplo, os funcionários no topo da hierarquia do Ministério da Educação poderiam desfrutar de um grau de liberdade em seus escritos impensável para os colegas do Departamento de Imprensa e Propaganda, confinados à repetição de um discurso autoritário nacionalista, voltado à doutrinação das camadas populares.

Outros nomes, como o de Daniel Pécaut, insistem na influência que os próprios intelectuais exercem na definição de sua função social, ou ainda na influência que uma opção religiosa pode exercer sobre a visão política. De acordo com esta visão, os vitalistas não teriam agido visando os ganhos materiais e simbólicos advindos dessa decisão, mas em atendimento a um compromisso estabelecido com a instituição religiosa à qual pertenciam. Em certa medida, Pécaut reproduz a visão que os autores da década de 1930 apresentam deles próprios ${ }^{51}$, isto é, como uma geração com a "missão histórica" de construir o Estado Nacional e terminar com quarenta anos de descaso das elites liberais com a sorte do país. Como justificativa para esta ideologia, era estratégico ignorar as continuidades das alianças políticas dos anos 1930 em relação ao período anterior e, consequentemente, o quadro das limitações para a ação de qualquer pretendente a um posto no contexto pós Revolução de Outubro de 1930.

Este debate reverbera em teses e dissertações produzidas nos últimos anos, como é o caso de Alexandre Gonçalves da Costa e Marcelo Lucena Diniz ${ }^{52}$. O primeiro

\footnotetext{
${ }^{51}$ A esse respeito, ver: OLIVEIRA, Lúcia Lippi. Introdução. In: OLIVEIRA, Lúcia Lippi; GOMES, Eduardo Rodrigues; WHATELY, Maria Celina. Elite intelectual e debate político nos anos 30. Rio de Janeiro/Brasília: Fundação Getúlio Vargas/INL, 1980, p. 31-60.

PÉCAUT, Daniel. Os intelectuais e a política no Brasil. São Paulo: Ed. Ática, 1990.

52 DINIZ, Marcelo Lucena. Os caminhos da intelectualidade católica na década de 1930: católicos e pioneiros na construção da ordem pública varguista. 2009. 159f. Dissertação (Mestrado em História) - Faculdade de História, Direito e Serviço Social, Universidade Estadual Paulista Julio de Mesquita Filho - Unesp, Franca, 2009.
} 
enxerga nos vitalistas o caso por exceência de alguns "funcionários-escritores" (MICELI, 2001), premidos pela submissão a mais de uma instituição ao mesmo tempo: o Estado e a Igreja. Marcelo Lucena Diniz nega explicitamente esta tese, preferindo adotar o ponto de vista de que os vitalistas agiam por convicção e em coerência com a interpretação correta da doutrina oficial da Igreja, com a possibilidade de determinar as políticas públicas.

A convicção de Diniz advém de uma simplificação ao ignorar, por exemplo, que mesmo o magistério da Igreja pode ser lido por diversos modos, não havendo portanto $a$ interpretação correta da doutrina da Igreja. Ao optar por um estudo detalhado de dois autores - Alceu Amoroso Lima e Otávio de Faria - Diniz cumpre seu objetivo de sistematizar as opiniões deles acerca da política brasileira e da forma de Estado ideal, mas perde a oportunidade de compreender qual o sentido atribuído a estes escritos na medida em que eles eram lidos e comparados a outros autores.

A dificuldade em sair do próprio texto para encontrar o modo como se formou sua fortuna crítica ainda naquele presente não é uma característica exclusiva da obra de Marcelo Diniz. A literatura sobre o tema tende a compreender a revista A Ordem, Amoroso Lima e eventualmente Jackson de Figueiredo ou algum outro membro do grupo como herdeiros de uma tradição que nasce com Júlio Maria e se encerra na meditação sobre os documentos pontifícios acerca da doutrina social da Igreja, acrescidos de alguns intelectuais franceses (Maritain, Bernanos) ou anglo-saxões (Chesterton, Thormas Merton). Esta chave interpretativa precisa ser complementada com a leitura outros órgãos da imprensa carioca e do jogo de punições e recompensas (simbólicas ou não) advindas da inserção deste grupo nas empreitadas assumidas pelo Centro Dom Vital.

Neste sentido, a tese pretende seguir as veredas trilhadas pelo estudo de Christiane Jalles de Paula sobre o protagonismo da amizade na gestão das lideranças laicas realizadas na Arquidiocese do Rio de Janeiro pelo Cardeal Leme (de 1921 até 1942) e pelo Cardeal Câmara (de 1943 até 1971). O texto prima pela perspicácia de introduzir o tema da amizade vivenciada por estes autores não apenas como um sentimento ou uma opção pessoal, mas como uma função social, na medida em que ela implica em lealdade, coesão e comunhão de visão de mundo (amparada, em última instância, na fé em uma realidade transcendente). Compreendida dessa forma, implica 
na formação de microssociedades essenciais para a história do catolicismo brasileiro do século XX:

O que chamo de microssociedades são os espaços e as redes de sociabilidade da intelectualidade católica que fixaram determinada perspectiva de agir como católico tanto nas disputas internas do campo do catolicismo quanto na sociedade brasileira. François Sirinelli (1996: 231-269) ressalta duas estruturas como essenciais para a apreensão das redes de sociabilidades no campo intelectual; a saber: as revistas e os manifestos e abaixo-assinados. Todavia, acredito que dada a especificidade do campo católico brasileiro, além destas também é preciso considerar o Centro Dom Vital um espaço importante da sociabilidade católica. ${ }^{53}$

A leitura do Centro como um espaço de reunião de intelectuais e compartilhamento de ideias é explorado em outro sentido por Fernando Pinheiro ${ }^{54}$, que radiografa outros frequentadores, como os poetas espiritualistas (Ismael Nery, Murilo Mendes e Jorge de Lima). Pinheiro opta por relativizar a importância do que se escreveu a partir do Centro (especialmente as obras de Jackson de Figueiredo e Tristão de Athayde) na linguagem poética adquirida por estes autores, visto que a pesquisa estética deles bebeu de diversas outras fontes além dos escritos da dupla. Por outro lado, há um grupo considerável de escritores entre os anos 1920 e 1940, que deixou sua marca no centro através de seus escritos.

Mapear estes autores é o tema do próximo capítulo, cujos esteios serão uma comparação de sua trajetória social e, complementando, uma análise de sua inserção no mercado editorial. Estes dois procedimentos permitem localizar mais precisamente quem são nossos objetos de pesquisa e a partir de que posição eles negociam sua participação na Igreja e no Estado.

\footnotetext{
${ }^{53}$ PAULA, Christiane Jalles de. Espaços de sociabilidade e relações de poder na igreja católica brasileira: o Centro Dom Vital através das trajetórias de Jackson de Figueiredo e de Gustavo Corção. In: Encontro Anual da Anpocs, 34, Caxambu. Apresentação de trabalho, 2011. Disponível em: <http://observatory-elites.org/anpocs-gt2010>. Acesso em: jan. 2013.

${ }^{54}$ PINHEIRO FILHO, Fernando Antonio. A Invenção da Ordem: Intelectuais Católicos no Brasil. Tempo Social, São Paulo, v.19, n.1, p.33-49, jun. 2007.
} 


\section{Capítulo II: O Grupo em Estudo}

"O Centro Dom Vital é a maior afirmação da inteligência cristã em terras do Brasil."

(Dom Sebastião Leme, 1929) 
A afirmação de Dom Leme foi feita em um momento de transição da liderança do Centro de uma figura carismática para outra, portadora de um grande reconhecimento público, mas apenas recém admitida às hostes vitalistas. A frase aparece dentro de uma pequena mensagem ao grupo reproduzida em fac-símile na edição de março de 1929 da revista e demonstra que, não obstante as mudanças ocorridas dali em diante, Leme continuava a chancelar o grupo em seu papel de ativamente propagar a opinião católica nos meios cultos. Este capítulo desenvolverá mais a fundo as condições que tornaram possível o sucesso deste empreendimento.

Em uma noite de maio de 1922, cerca de vinte homens ${ }^{55}$ (não há registro de nenhuma mulher presente) se reuniram com o fito de encontrar soluções para o problema que consideravam o mais grave do país: a ausência do catolicismo da vida pública. Os sinais dessa perda de importância iam muito além da falta de símbolos religiosos nas repartições. Havia reformas educacionais como a promovida pelo governo estadual de São Paulo, no início da vida republicana, que afastavam cada vez mais a religião dos currículos escolares; os anarquistas e seu anticlericalismo ganhavam vigor no seio do movimento operário. A insegurança provocada pelas greves se traduzia em diversas perguntas: qual poderia ser a contribuição das Encíclicas ${ }^{56}$ e outros

\footnotetext{
${ }^{55}$ De acordo com o Dicionário Histórico-Biográfico Brasileiro, os fundadores do Centro são: Jackson de Figueiredo (presidente), Hamilton Nogueira (vice-presidente), Perillo Gomes (secretário), José Vicente de Sousa (tesoureiro) e Vilhena de Morais (bibliotecário). Leonel Franca foi designado assistente eclesiástico. São também registrados como doadores: Durval de Morais, Jônatas Serrano, Mário de Paulo Freitas e Alceu Amoroso Lima, além dos professores Leonardo von Acker e Lacerda de Almeida. Havia também referências aos poetas Nestor Vítor, Tasso da Silveira, Andrade Murici, José Barreto e outros do movimento literário "A Festa" que constavam como colaboradores (DHBB, 2001)

${ }^{56}$ A Encíclica é um gênero entre os documentos publicados por um Papa, escrito em forma de carta endereçada a todos os bispos e, através deles, a todos os fiéis. Trata de assuntos que não são objeto de dogma, mas considerados de importância suficiente para merecer a atenção e a obediência de todos os católicos aos preceitos estabelecidos por ele. Para os objetivos da pesquisa, uma das principais encíclicas foi a Rerum Novarum, de 1891, cujo tema principal foram as condições de trabalho e de sobrevivência do crescente número de operários nas grandes fábricas. O Papa Leão XIII combate firmemente o comunismo ao mesmo tempo em que imputa o avanço deste aos desacertos do liberalismo econômico. No momento de criação do Centro, esta era a principal referência política para os vitalistas. Também são referências importantes para o período as encíclicas Immortale Dei, que estabelece a obediência do cidadão ao Estado-nação do qual faz parte como um dever de todo católico e a Mirari Vos, na qual está expressa a recusa ao liberalismo e a toda forma de modernismo. Em 1931, uma nova Encíclica é lançada em comemoração aos quarenta anos da Rerum Novarum. A Quadragesimo Anno atualiza os princípios sociais expostas na Rerum Novarum, mas apresenta algumas inovações trazidas pelo fascismo como sendo a possibilidade de um caminho de afirmação da reforma social sem prejuízo da ordem capitalista.
} 
documentos oficiais para a solução das agitações sociais do período? O que impedia que estes ensinamentos fossem colocados em prática no Brasil?

Ao mesmo tempo em que persistiam estes aspectos deletérios para a nacionalidade, também havia elementos de esperança. No Rio de Janeiro, um grupo de poetas jovens escrevia sobre temas místicos e religiosos; em São Paulo, alguns exemplos isolados também demonstravam apreço pela temática religiosa ${ }^{57}$. Além disso, o grupo reunido naquela noite podia se orgulhar de já ter começado a fazer sua parte: eles haviam criado uma revista no ano anterior, com o sugestivo nome de A Ordem, que se tornou em pouco tempo um periódico de amplitude nacional. Era necessário desdobrá-lo em novos projetos, como a instituição fundada naquele dia e que viria a ser uma das mais relevantes na história da Igreja do século XX: o Centro Dom Vital.

A maior parte dos homens presentes a esta reunião eram egressos da Faculdade Livre de Direito do Rio de Janeiro. Nota-se uma ausência quase completa dos representantes oriundos de outros centros de formação de bacharéis - principalmente os mais tradicionais do país: São Paulo e Recife ${ }^{58}$. Considerando que a Faculdade estava localizada na mesma cidade que o Centro, seria natural esperar que a maior parte dos membros viesse dessa instituição. Mas a ausência quase completa de pessoas com outras trajetórias -- apenas Figueiredo havia estudado Direito entre Recife e Salvador é digna de nota. Em acréscimo, a ausência de engenheiros e a baixa presença de médicos -- apenas Hamilton Nogueira era formado em Medicina -- poderia ser explicada pela tradição positivista, forte nestes dois grupos desde o final do Império e o início da República, ainda a funcionar como um obstáculo ao ingresso de pessoas destas profissões no Centro.

Os dados a respeito do percurso universitário exige considerar certos aspectos adicionais na caracterização do grupo, como, por exemplo, o papel desempenhado pela faculdade como espaço de formação profissional e de sociabilidade. Teria a formação jurídica e de pensamento social feito alguma diferença na trajetória dos vitalistas? Para

\footnotetext{
${ }^{57}$ Ver mais abaixo neste mesmo texto comentários a respeito sobre os livros de estreia de Plinio Salgado e Mário de Andrade.

${ }^{58}$ Esta baixa representatividade ganha ainda mais destaque quando comparada com o estudo exaustivo feito por Lúcia Lippi Oliveira sobre os autores da década de 1930 que, de alguma forma, abordam as transformações política resultantes da ascensão da Aliança Liberal ao poder. Nesta população, as duas escolas de Direito estão bem representadas. Ver (OLIVEIRA, 1980).
} 
responder a esta pergunta, é necessário levar em consideração que as faculdades livres de Direito haviam sido pensadas para suprir a crescente demanda por pessoal especializado, nascida da transferência de funções e prerrogativas do governo central para os estados, exigindo a contratação de mais pessoas para gerir as máquinas burocráticas regionalizadas ${ }^{59}$. Um dos efeitos indesejados dessas novas faculdades criadas ao longo da Primeira República foi produzir um crescimento no número de títulos universitários muito acima da quantidade de cargos criados.

Outro ponto em comum destes autores é que a posse do grau de bacharel não implicou em uma carreira bem sucedida nas searas mais prestigiadas do Direito -- esse foi o caso, por exemplo, de Tristão de Athayde, Jackson de Figueiredo, Jônathas Serrano e Tasso da Silveira. Nenhum deles foi magistrado ou advogado de renome, com a exceção de Sobral Pinto.

Sobral Pinto era proveniente de família de remediados e contou com bolsa dos jesuítas para completar seus estudos básicos. Reproduziu o ambiente fervorosamente católico de sua família, instalada no interior de Minas Gerais, inicialmente na fronteira com o estado do Rio de Janeiro, em seguida mais adentrado no estado. Participou da efervescente campanha civilista e foi amigo de escola do futuro padre Leonel Franca. Depois de destacar-se no colégio Anchieta, Sobral Pinto fez Direito na Faculdade de Ciências Jurídicas e Sociais (também frequentada por Tristão) enquanto trabalhava nos Telégrafos. Demonstrou afeição ao catolicismo e à sua madrinha, cuja filha em pouco tempo se tornaria sua esposa. Em uma trajetória sempre ascendente, fez amizade durante a faculdade com Benjamin Antunes de Oliveira Filho, Mário Bulhões Pereira e João Martins de Carvalho. Sua carreira lhe permitiu viver em Tijuca e em 1923 trabalhou para o caso do Copacabana Palace, no qual defendeu o direito desse hotel de abrir cassino e uma casa de jogos. Dulles (1991) estima que a renda do caso tenha girado em torno do equivalente a 1000 dólares na época.

Apesar da boa remuneração e do cliente famoso, não seria por esse caso que Sobral se tornaria conhecido, mas pela atuação como procurador criminal, iniciada em

59 A este respeito, cf. CHAVES, André Aparecido Bezerra. A Revista da Faculdade Livre de Direito do Rio de Janeiro: uma proposta para a Identidade Jurídica Nacional Brasileira. 2011. 130 f. Dissertação (Mestrado em História Social) - Faculdade de Filosofia, Letras e Ciências Humanas, Universidade de São Paulo - USP, São Paulo, 2011. 
1924 em caráter interino e como efetivo no ano seguinte. Sobral Pinto exerceu forte perseguição a comunistas, tenentistas e quaisquer outros opositores de Bernardes, cujo apoio a ele foi constante durante todo o período. Manteve seu compromisso de defender a ordem oligárquica até após outubro de 1930 e suas críticas preocuparam Vargas. A resposta deste foi um gesto inteligente de estratégia que tinha o objetivo de enfraquecer dois inimigos ao mesmo tempo.

Quando os membros do Partido Comunista foram presos em 1935 após a Revolta, designou como seus defensores o mesmo advogado que havia se destacado no combate a eles na década anterior. A atuação de Sobral Pinto a favor dos presos políticos lhe custou a repulsa pública o escritório vazio de clientes por um bom tempo, mas o recompensou em termos de reconhecimento pela defesa dos direitos humanos. $\mathrm{O}$ fato de Sobral Pinto ser lembrado durante esta época como alguém intrinsecamente ligado à luta pelos direitos humanos convive com a ausência de uma carreira lucrativa em outros ramos do Direito. A biografia de Sobral Pinto feita por Dulles realça seus constantes problemas de falta de dinheiro no período.

Isso significa dizer que alguns membros do Centro, mesmo durante a década de 1920, possuíam notoriedade pública suficiente para fazer sua existência conhecida na Capital Federal. No caso de Jackson de Figueiredo, menos por seu papel de censor ${ }^{60}$ do que pelos livros que publicava. Na Gazeta de Notícias, um dos principais jornais da capital federal, cada novo livro de Jackson era objeto de uma crítica positiva ${ }^{61}$. Ou também pelos artigos que publicou entre 1923 e 1924 na Gazeta de Notícias, no bojo de uma linha editorial marcadamente a favor do presidente Bernardes. A atuação de Sobral Pinto como procurador criminal também era coberta pelos jornais ${ }^{62}$.

No caso de Serrano, seu envolvimento com atividades religiosas era tão considerável que em sua fase de adolescência seus familiares lhe imputavam a carreira sacerdotal ou a jurídica (ZANATTA, 2005). Seu pai havia sido militar e senador, mas

\footnotetext{
${ }^{60}$ Nas biografias produzidas por amigos e descendentes de Figueiredo, seu papel de censor é ignorado ou diminuído, como uma necessidade que ele teria assumido apenas por questões financeiras.

${ }^{61}$ Como demonstram os seguintes artigos: Lacerda de Almeida, "Mais um livro sobre Farias Brito" , Gazeta de Notícias, 08/09/1919. "Livros Novos -- Humilhados e luminosos", Gazeta de Notícias, 20/02/1921. "Livros Novos -- Do Nacionalismo na hora presente", Gazeta de Notícias, 11/04/1921. "Livros Novos -- Pascal e a inquietação moderna", Gazeta de Notícias, 07/07/1922. "Um livro de Jackson de Figueiredo apreciado em Portugal", Gazeta de Notícias, 03/05/1923. A Gazeta de Notícias era um jornal de linha editorial marcadamente favorável ao regime de Arthur Bernardes e isso pode ter influenciado a leitura

62 "Tribunais e Juízos”, O Paiz, 05/01/1926. "Conselho Penitenciário”, O Paiz, 29/01/1926.
} 
falecera muito cedo, deixando Jonathas aos cuidados da mãe e da avó. Esteve envolvido de 1908 a 1928 como fundador e presidente da União Católica Brasileira e de seu órgão oficial Revista Social. Escreveu um único romance, Ludovico, premiado pela Academia Brasileira de Letras; um capítulo sobre o clero e a República na coletânea de Vicente Licínio Rodrigues, publicada em 1924 sob o nome de À margem da História da República, junto com vários nomes de peso, entre os quais Gilberto Amado, Ronald de Carvalho, Tasso da Silveira, Tristão de Athayde, Oliveira Vianna e Vicente Licínio Cardoso, organizador da coletânea.

$\mathrm{Na}$ análise de José Murilo de Carvalho ${ }^{63}$, a obra se tornou uma matriz importante para pensar a Primeira República, pois seus autores partilhavam a concepção de que o regime estava em crise e a solução residiria na ampliação da educação básica e na reforma constitucional, para interromper o fosso existente entre as leis e os costumes. Carvalho aponta com razão para a desconfiança presente todos os pontos de vista expressos na coletânea em confiar no povo como um elemento positivo nas modificações necessárias. Exemplo disso são os outros artigos do mesmo livro, como o de Oliveira Vianna, que preferiu confiar o trabalho de reforma a legisladores conscientes, Gilberto Amado a uma "elite ilustrada" e Jonathas Serrano defende o protagonismo do clero em tais transformações, sob a justificativa de que ele sempre desempenhou seu papel de defensor do progresso na vida pública brasileira.

Para sustentar seu ponto de vista, Serrano apresentou a figura do padre Júlio Maria, evocado como autor de uma das matrizes possíveis para a interpretação da História brasileira. Outro paradigma de interpretação do país é sugerido neste mesmo livro pelo artigo de Tasso da Silveira, a partir da obra de Farias Brito. A filosofia espiritualista, em substituição ao positivismo do início da República seria a matriz filosófica mais indica para a compreensão da identidade nacional.

Em virtude de sua participação em empreitadas editoriais de sucesso considerável, Serrano chamou a atenção de Amoroso Lima, que em coluna publicada

${ }^{63}$ CARVALHO, José Murilo. Os três povos. In: HOMEM, Amadeu Carvalho; DA SILVA, Armando Malheiro. Progresso e religião: a República no Brasil e em Portugal 1889-1910. Coimbra: Imprensa da Univ. Coimbra, 2007, p. 131-164. [Publicado originalmente em: CARVALHO, Alice Resende de. República no Catete. Rio de Janeiro: Museu da República, 2002, pp. 61-87]. 
em abril de 1920 critica Serrano por seu "cego partidarismo" (palavras do próprio Alceu) ao afirmar que apenas pela ação da Igreja poderia de fato registrar-se um progresso moral da humanidade. A resposta aparece em carta pessoal endereçada a ele, datada de 20 de Abril de 1920. ${ }^{64}$ Nela Serrano procura se defender da reprovação feita por Alceu mas termina por confirmar inadvertidamente a opinião de seu interlocutor. Ele estabeleceu um longo raciocínio para afirmar que quando alguém que não crê ou é até contrário à fé realiza algo conforme os valores cristãos, é a Igreja a responsável por aquele ato, pois caso ela não tivesse formulado tais valores, a boa ação não existiria.

Além de dar aulas na Escola Normal, Serrano foi subsecretário na Secretaria da Educação do Rio de Janeiro durante a década de 1920 e professor do Colégio D. Pedro II. Esta breve análise de seu percurso profissional durante o período permite vislumbrar o tipo de trajetória estabelecido pela maioria dos vitalistas, que passearam entre a defesa dos interesses da Igreja e a ocupação de postos na esfera pública, com as relações estabelecidas entre estas ocupações e o tipo de texto que escrevem.

No caso de Tristão de Athayde, existe um fator a tornar a relação entre os escritos e a atuação profissional um pouco mais complexa. Sua participação na imprensa era mais uma atividade em meio à administração da fortuna considerável que a família acumulou em atividade empresarial no ramo têxtil e à gestão do imenso capital social acumulado, com uma série de conexões com pessoas de suma importância na sociedade de seu tempo. Foi em grande medida graças a isso que logrou desempenhar seu papel de líder do laicato católico, assumido repentinamente em 1928. Como era padrão nas famílias mais abastadas, sua alfabetização ocorreu na própria casa e o tutor foi João Kopke, que viria a se tornar posteriormente uma referência para a Escola Nova. Em sua mocidade, frequentou os salões literários de Sousa Bandeira, Inglês de Souza e Rodrigo Otávio. Era cunhado ao mesmo tempo de Afrânio Peixoto e Octavio de Faria.

Em relação à prática religiosa prévia ao ingresso no Centro, havia entre os adeptos do Centro Dom Vital aqueles que trouxeram o catolicismo de sua formação familiar, como era o caso de Jônathas Serrano ou Vilhena de Morais. Nos casos de Jackson de Figueiredo e Athayde, suas narrativas possuem diversas características em comum. As mães eram católicas fervorosas e os pais, indiferentes à religião. A

\footnotetext{
${ }^{64}$ A carta encontra-se hoje depositada no Centro Alceu Amoroso Lima para a Liberdade e
} graças ao projeto do site www.alceuamorosolima.com.br está disponível em formato digital. 
formação escolar realizada fora da rede católica tivera um efeito devastador nas jovens almas, que até a fase adulta não tiveram a possibilidade de experimentar a fé. As narrativas possuíam a força do filho pródigo, cujo retorno à crença confirma seu valor. Além disso, remetem ao problema enfrentado no presente dos anos 1920: a concorrência com as escolas públicas e as protestantes, como demonstra a seguinte passagem de Figueiredo:

Eu viera de um colégio protestante, tivera de aprender a Bíblia como se aprende Aritmética, fizera dezenas de perguntas e não tivera respostas razoáveis, numa idade em que o homem, criança ainda, principia a assenhorear-se do mundo pelo instrumento utilitário da razão.

Quando vi pessoas que só falavam em nome da razão, pus-me a escutá-las com a ingenuidade de um crente fervoroso - tive os meus novos dogmas, e aquilo que os ferisse tinha o meu desprezo. ${ }^{65}$

Raciocínio semelhante é desenvolvido por Tristão de Athayde em "Tentativa de Itinerário" (1929), texto escrito para a mocidade da Ação Universitária Católica, no qual faz referência à "educação sem alma que nos deram nos Colégios do Estado leigo", nos quais os jovens aprendiam a "ironia e o ceticismo dos mestres que nos formaram"... era a "geração da melancolia", arrematava ${ }^{66}$. Estes testemunhos podem ser contrabalançados por posturas como a de Serrano, cujo envolvimento com a produção de textos para o Centro conviveu com a participação nas reformas educacionais promovidas por Fernando de Azevedo, na capital federal, a partir de 1928.

Essa reforma apresentaria algumas características do embate entre escolanovistas e católicos da década seguinte: a identificação da causa da reforma pedagógica com o perigo de uma revolução, fato que provocou um debate intenso sobre as medidas. $\mathrm{O}$ clima de tensão que cercava a implementação dos planos de Azevedo pode ser observado a partir de um dos participantes da reforma, Edgard Sussekind de Mendonça, para quem ela seria "uma obra formidável de ressurreição popular que o regime dos

\footnotetext{
${ }^{65}$ FIGUEIREDO, Jackson. Algumas reflexões sobre a filosofia de Farias Brito, 1916.

${ }^{66}$ LIMA, Alceu Amoroso. Tentativa de Itinerário. In: Adeus à disponibilidade e outros adeuses. Rio de Janeiro: Agir, 1969.

A temática de uma juventude passada em pleno mal-estar de viver, sem uma causa pela qual fosse digno entregar a própria vida, é retomada em diversos outros escritos biográficos, até o final da vida.
} 
sovietes permitiu mas que, na própria Capital brasileira, ainda tem que suportar a detratações (sic) dos mais 'ardorosos' republicanos" ${ }^{\text {67. }}$.

Mendonça não nomeia seus adversários, mas uma lista dos palestrantes da mesma série à qual ele pertencia indicava que Vicente Licínio Cardoso havia feito a conferência de abertura e Everardo Backheuser - outro fundador do Centro Dom Vital ficara responsável pela palestra referente à defesa da pedagogia de Kerschensteiner ${ }^{68}$. Era de se supor que os participantes da série fossem favoráveis à reforma, o que poderia indicar que seu espectro de apoio era consideravelmente amplo.

No extremo da dependência e da dedicação completa às causas apresentadas pela Igreja estava Leonel Franca, um jesuíta que cursou as faculdades de Filosofia e de Teologia na Universidade Gregoriana, a mais prestigiada dentro do universo católico ${ }^{69}$. Os dados sobre Leonel Franca o aproximam de outra grande figura do período, o Cardeal Leme, que também se beneficiou do apoio da Igreja e foi portador de uma trajetória típica dos oblatos da Igreja (MICELI, 2009), isto é, daqueles que concentram todos os esforços e devem tudo que obtêm à proteção de algum nome importante da hierarquia. No caso de D. Leme, essa figura foi D. Duarte Leopoldo, seu reitor durante o tempo de seminário e que notou sua disposição para os estudos e para o serviço litúrgico. Entre os pesquisadores que escreveram a respeito de Dom Leme, muitos recolheram suas informações a partir de sua biografia oficial, redigida por Raja Gabaglia. A ênfase destes trabalhos recai sobre o período no qual ele já se encontrava em plena atividade de bispo, a comandar as tropas de leigos que trabalharam sob suas ordens, primeiro em Recife (1916) e logo no Rio de Janeiro, em 1921.

\footnotetext{
${ }^{67}$ A REFORMA do ensino e a escola nova, A Esquerda, 10 maio 1928, p. 1.

Edgard Sussekind de Mendonça viria a se destacar como um defensor ardoroso da Escola Nova, tendo assinado o "Manifesto dos Pioneiros". O jornal para o qual a entrevista foi concedida pertencia a Pedro Mota Lima e expressava a opinião do Partido Comunista Brasileiro. Assumiu como suas causas principais a defesa do operariado e a crítica às potências estrangeiras que transformavam o Brasil em uma colônia.

${ }^{68}$ Georg Kerschensteiner (1850-1932) foi um educador bávaro leitor de Eduard Spranger, Dewey e Pestalozzi, a partir dos quais formulou uma pedagogia que valorizasse a inteligência prática de seus alunos e sua formação profissional. SAVIOZ, R. Georg Kerschensteiner. In: CHÂTEAU, Jean. Los Grandes Pedagogos. México: Fondo de Cultura Económica, 1992, p. 234-237.
}

${ }^{69}$ D'ElbouX, Luiz Gonzaga da Silveira. O Padre Leonel Franca. Rio de Janeiro: Agir, 1953. 
Essa opção de pesquisa não permite enxergar marcos de trajetória importantes na infância e juventude de dom Leme, que em alguns casos são muito próximos dos de Leonel Franca. Ambos sofreram casos de morte precoce na família. Sebastião Leme perdeu o pai pouco depois de nascer, despejando a família que então se iniciara em uma situação de insegurança econômica, agravada pela morte de seu padrasto. Além de assumir diversos trabalhos menores, sua mãe se viu obrigada a pôr o jovem Sebastião para trabalhar na venda de um tio. De lá, Sebastião Leme saiu quando ingressou no Seminário. (RAJA GABAGLIA, 1962) Leonel Franca também ingressou bastante jovem no seminário, um colégio jesuíta em Nova Friburgo encontrado pela família na impossibilidade de o pai cuidar dos filhos após a morte de sua esposa.

Para além das circunstâncias nas quais ingressaram no seminário, Franca e Leme apresentam outros paralelos. Ambos receberam recompensas consideráveis pelo esforço demonstrado durante seu período de formação, com a estadia em Roma. Ambos enfrentaram problemas de saúde que representaram um risco permanente à realização de uma trajetória eclesial bem sucedida. Os problemas de coração de Franca fizeram-no recusar uma oferta para permanecer em Roma e tornar-se professor de teologia na Universidade Gregoriana; por seu lado, Dom Leme sofria de uma disfunção da glândula tireoide que limitava sua capacidade física de suportar longos períodos de trabalho. Segundo Raja Gabaglia, este seria um dos fatores capazes de explicar o tipo de liderança exercida por Dom Leme, isto é, com uma larga participação dos leigos na administração diária das crescentes atividades da diocese.

Em termos de reconhecimento intelectual, os vitalistas se encontravam em níveis bastante desiguais no começo da década de 1920. Por seu compêndio Noções de História de Filosofia, publicado em sua primeira versão em 1919 e reeditado com acréscimos duas vezes durante a década seguinte, Leonel Franca era nome já reconhecido nos meios católicos brasileiros como um professor de filosofia. Além disso, esteve sempre ligado ao ensino no colégio de sua ordem no Rio de Janeiro, o Santo Inácio, no qual estudou boa parte da elite carioca do período. Nas décadas seguintes, sua atuação se concentraria na criação de algumas faculdades católicas e na universidade que, por excelência, se tornou o projeto católico no ensino superior: a PUC-RJ, da qual foi o primeiro reitor. 
Figueiredo também havia obtido algum destaque por suas obras e por sua participação na imprensa, optando por um caminho distinto de Franca, pois nunca escreveu livros didáticos. Dedicou-se aos artigos de jornal e pequenas obras, de temas e pretensões razoavelmente limitadas. Atuou como professor de ensino secundário e superintendente das instituições escolares do Ministério da Agricultura. Antes disso, logo ao chegar no Rio de Janeiro, foi revisor de debates na Câmara Federal e censor. Embora fosse bem menos conhecido que Figueiredo, Hamilton Nogueira fez brilhante carreira no ensino de Biologia e Medicina em diversas instituições. A partir de 1929, foi livre-docente na Faculdade de Medicina do Rio de Janeiro.

Jackson foi um dos primeiros a ligar a projeção de seu nome ao de Tristão, com quem se correspondia por cartas quase diárias e a quem dedicava livros. ${ }^{70} \mathrm{Em}$ resposta, este manteve a correspondência sempre ativa e deu algumas declarações de apoio a Jackson. Em meio às trocas de cartas, ambos traçaram uma trajetória de valorização de seus nomes nos meios sociais cariocas, mas a natureza dessa valorização e o seu alcance foram muito distintos. No caso de Athayde, sua origem abastada já lhe garantiria um nome digno de nota, ao qual se acrescentou a fama obtida com a crítica literária. No caso de Jackson de Figueiredo, seu nome seria associado à defesa medular do bernardismo, com sua intransigência quanto aos inimigos políticos e apesar da incapacidade de combater a crise social. Figueiredo pugnou pelo uso da pena de morte para crimes políticos ${ }^{71}$ e acumulou diversos cargos ao longo de sua carreira profissional $^{72}$, mas a imagem que permaneceu era de alguém em constantes apuros financeiros, pois escrevia a diversos amigos para reclamar da falta de oportunidades no Rio de Janeiro de um emprego fixo, com horários e pagamentos que lhe permitissem

\footnotetext{
${ }^{70}$ Em 1921, Figueiredo dedicou seu livro Afirmações a Alceu, "a quem verdadeiramente amo e admiro", para citar suas próprias palavras. Cf: FIGUEIREDO, Jackson. Afirmações. Rio de Janeiro: Centro D. Vital/Tipografia Anuário do Brasil, 1921.

${ }^{71}$ Jackson de Figueiredo abre uma frente de defesa da pena de morte que seria em breve seguida por outros vitalistas explicitamente inspiradas nele, como é o caso de Perillo Gomes. Cf.:

GOMES, Perillo. Jackson de Figueiredo: o doutrinador político. Rio de Janeiro: Centro D. Vital, 1926.

${ }^{72}$ Jackson foi também revisor de Debates na Câmara (desde 1914): professor de Pedagogia da Escola Wenceslau Braz (1917-1928), membro da Comissão de Ensino Superior e Fiscal Federal no Liceu do Sul de Minas; Superintendente de Institutos de Ensino subvencionados pelo Ministério da Agricultura (1926).
} 
fazer grandes investimentos em sua própria formação ${ }^{73}$. Após seu falecimento, Amoroso Lima veio a público pedir uma ajuda para a viúva e os filhos, para os quais Figueiredo não havia deixado nada em provisão ${ }^{74}$.

Estes dados seriam retomados nas descrições posteriores feitas em homenagem a Jackson e ajudaram a caracterizá-lo como uma espécie de mártir da causa. Em número d'A Ordem publicado em sua homenagem ${ }^{75}$, menciona-se o fato de que ele aceitara advogar um caso em Muzambinho apenas para saldar suas dívidas, das quais ele não se lembrava ou nem conhecia sua existência, boa parte delas causada por artigos de jornal pelos quais ficava sem receber ${ }^{76}$.

A escolha de Sebastião Leme por apoiar-se em um nome envolvido de corpo e alma na defesa do governo vigente implicava necessariamente em um posicionamento político partidário. Essa condição foi modificada pela escolha de Amoroso Lima como presidente; assim que passou a editar a revista, alterou o foco d'A Ordem da política para a religião e a cultura. Por outro lado, se comprometia a ser fiel nas linhas gerais de pensamento político definidas por seu antecessor.

Alterações importantes ocorreriam após o Outubro de 1930, quando a neutralidade do Centro em relação à crise final do governo Washington Luiz garantiu que ele não seria incomodado pelo novo poder governante. Não se trata de afirmar que Dom Leme teria a antevisão em 1928 de que o regime republicano estaria prestes a passar por um grande abalo, mas de lembrar que a "recristianização do Brasil", tal como pregada desde a Pastoral de $1916^{77}$, exigia a participação na situação política do

\footnotetext{
${ }^{73}$ Tal como expresso, por exemplo, em carta a Perillo Gomes, data de 3/9/1919 e publicada postumamente em: FIGUEIREDO, Jackson. Correspondência. Rio de Janeiro: Agir Editora, 1945 ( $2^{\mathrm{a}}$ edição aumentada).

${ }^{74}$ EDITORIAL, A Ordem, 1928.

${ }^{75}$ A Ordem, número especial, 1929.

${ }^{76}$ Esta imagem de Figueiredo perdura na obra mais recente a seu respeito, que data de 1989 e foi redigida por sua neta: FIGUEIREDO, Cléa. Jackson de Figueiredo: uma trajetória apaixonada. Rio de Janeiro: Forense, 1989. Embora não fosse a intenção do título, a defesa intransigente que a autora faz de seu avô nos leva a pensar que a paixão está também nos olhos de quem escreve a obra. Apesar de cometer vários excessos, o livro traz uma vida detalhada sobre Jackson. Para entender seu pensamento sobre política, permanece como a melhor obra o livro de Francisco Iglésias:

IGLÉSIAS, Francisco. Estudo sobre o pensamento de Jackson de Figueiredo. In:
}

História e ideologia. São Paulo: Perspectiva, p. 109-158.

${ }^{77}$ A Pastoral foi publicada por Dom Sebastião Leme quando foi nomeado para a Diocese de Olinda, e foi o primeiro documento no qual enuncia o que seria uma das ações principais de seu 
momento e o apoio ao status quo. Os últimos regimes da Primeira República procuraram capitalizar a aproximação: Arthur Bernardes participou de diversas cerimônias religiosas e concedeu benesses à Igreja, na expectativa de que isto o ajudasse a reconquistar uma base mais segura de apoio. A mudança de regime poderia ter implicado em uma reversão desta tendência, sobretudo levando-se em conta a atuação do então deputado federal Vargas na reforma da Constituição em 1926, quando votou contra os interesses da Igreja. Nesta nova situação, ele e Leme estabeleceram uma aliança, selada pela consagração do país a Nossa Senhora Aparecida e a inauguração do Cristo Redentor.

A firmeza da condução de Figueiredo no apoio a um sistema político degringolante implicou em dissensos, como foi o caso de Vilhena de Moraes e Jônathas Serrano, que se retiraram do Centro por discordarem da defesa intransigente do bernardismo. Ao contrário, a presidência de Amoroso Lima soube contornar os momentos de dissensão do grupo -- principalmente a revolução de 1930 e a de 1932. COSTA (2010) trabalha a hipótese de que, na verdade, as alterações implementadas por Alceu no grupo já faziam parte de uma ideia consensual no grupo, em oposição aos nomes mais próximos de Jackson de Figueiredo - como Sobral Pinto, que desejava utilizar o Centro para institucionalmente condenar o movimento da Aliança Liberal. Administrativamente, Amoroso Lima também imprimiu modificações importantes: aumentou o número de associados e o público da revista, A Ordem, que se mantinha a partir das subscrições de seus membros. As 570 assinaturas que a revista possuía em 1931 foram triplicadas em três anos. No que diz respeito ao número de unidades, da sede única que o Centro possuía no final de 1928 - momento em que Amoroso Lima assumiu a presidência do Centro - chegou-se ao número de treze unidades em 1937.

A expansão do Centro foi facilitada pelas poucas condições impostas pelo Estatuto do Centro D. Vital do Rio de Janeiro para que outros núcleos fossem instalados. Bastava a manifestação do interesse local em fazê-lo à sede e a concordância com as regras de obediência estrita aos ditames da Igreja. Se respeitada esta marca de submissão, a autonomia estava assegurada conforme rezavam os artigos $29^{\circ}$ e $30^{\circ}$ :

Art $29^{\circ}$-- O "Centro D. Vital” do Rio de Janeiro procurará difundir a sua ação por todo o Brasil, promovendo a fundação de núcleos do

bispado nesta cidade e no Rio de Janeiro: a formação de uma elite de intelectuais católicos em defesa de sua fé. 
mesmo gênero, sob a mesma denominação em todos os Estados, com plena autonomia de ação, mas dentro das normas do artigo seguinte. Art $30^{\circ}$-- Cada uma dessas sedes organizará o Centro com plena autonomia, e personalidade jurídica, acrescentando ao título a designação da cidade em que for instalado e subordinando-se às seguintes condições:

a) Que seus Estatutos e atos sejam aprovados pela Autoridade Diocesana local;

b) Que seja, por esta, designado um assistente eclesiástico para acompanhar os trabalhos da associação;

c) Que tais Estatutos não contravenham as disposições fundamentais destes, especialmente quanto à finalidade do Centro. ${ }^{78}$

As finalidades do Centro às quais o artigo faz menção resumem-se à organização de cursos, fundação de uma biblioteca e publicação de livros úteis à Religião e ao Brasil, além das esperadas reuniões periódicas. Estes estatutos foram aprovados em 1931 e permaneceram válidos por toda a década. O chamado para participar do Centro é aceito por diversos grupos estaduais. Em 1935, por exemplo, havia unidades suas em cinco capitais do Nordeste: Recife, Salvador, Aracajú, Fortaleza e Maceió. Apenas no estado de Minas Gerais registravam-se também seis unidades: Belo Horizonte, Itajubá, S. João Del Rey, Juiz de Fora, Ouro Preto e Uberaba. No Estado do Rio ${ }^{79}$, outros dois centros: Niterói e Campos. Fora desse arco, apenas as cidades de São Paulo e Porto Alegre tinham unidades afiliadas ao Centro do Rio.

A forte presença de unidades do Centro Dom Vital no Rio de Janeiro, Minas Gerais e nos estados do Nordeste pode ser relacionada com o perfil dos grupos no comando político destes estados, nos quais o rearranjo político permitiu a manutenção de seus representantes após a troca de regime em 1930. E, no interior da burocracia federal, mineiros e nordestinos trabalharam para conferir às políticas públicas implementadas pelos Ministérios da Educação e do Trabalho um perfil mais conservador, abdicando de alterações mais radicais.

No que concerne à documentação de época analisada, ela inclui os livros e artigos redigidos pelos próprios autores estudados e se amplia para os comentários a seu respeito presentes na imprensa da capital federal. É nesta cidade que se encontram

\footnotetext{
${ }^{78}$ ESTATUTOS do Centro D. Vital do Rio de Janeiro, A Ordem, ano XII, n. 11, p. 58-60, jan. 1931.

${ }^{79}$ Que, naquele tempo, equivalia ao atual estado do Rio de Janeiro sem a capital federal.
} 
periódicos dos mais variados matizes políticos, permitindo vislumbrar a reação aos escritos dos vitalistas e como eles são vistos em seu conjunto. $\mathrm{O}$ mesmo ocorre com os textos de crítica literária ou artística, nos quais é possível observar as estratégias de grupo estabelecidas.

A escolha pela imprensa carioca também se justifica pelo fator geográfico: estava nessa cidade a primeira experiência de Centro Dom Vital, da qual saíram funcionários para os Ministérios da Educação e do Trabalho, como já foi visto. Também era no Rio de Janeiro que se constituíram dois projetos editoriais marcados pela identidade católica: A Ordem (do Centro Dom Vital) e Vida (da Ação Universitária Católica). Em outro texto ${ }^{80}$ já discuti alguns aspectos d'A Ordem, em especial de suas colunas permanentes sobre a literatura, a situação política do país e de crônica feminina. Para além do que foi escrito lá, acrescento outros aspectos à análise.

A Ordem foi criada em 1921, por Jackson de Figueiredo e foi publicada mensalmente. Trazia em suas primeiras páginas editoriais voltadas a algum aspecto programático que a revista esperava incutir em seus leitores. Nesta categoria podiam estar incluídos artigos sobre o dever de formação doutrinária, ${ }^{81}$ ou sobre a melhor atitude a tomar diante da situação política do país, por exemplo. Os outros artigos publicados na revista não seguiam ordem exata e nem houve uma proporção fixa entre os temas cobertos pela revista. Sociólogos pouco conhecidos fora do ambiente clerical do período, tais como Henri de Tourville ou Giuseppe Toniolo, são evocados como modelos teóricos de produção científica. Em contraponto, a revista passa ao largo de discussões culturais importantes no período, mantendo-se silenciada no momento de lançamento de livros clássicos como o Raízes do Brasil, ou Formação Econômica do Brasil Contemporâneo.

A respeito de Vida, faremos alguns comentários adicionais no capítulo seguinte, reservando este espaço para a discussão de alguns de seus aspectos morfológicos. $\mathrm{O}$ jornal era publicado mensalmente entre abril de 1934 e dezembro de 1936 e se definia

\footnotetext{
${ }^{80}$ ARDUINI, Guilherme Ramalho. O Centro D. Vital: estudo de caso de um grupo de intelectuais católicos no Rio de Janeiro entre os anos 1920 e 1940. In: RODRIGUES, Cândido Moreira; PAULA, Christiane Jalles de. Intelectuais e militância católica no Brasil. Cuiabá: Editora UFMT, 2012, p. 45-73.

${ }^{81}$ O DEVER cultural dos católicos, A ordem, n. 26, p. 241-246, abr. 1932. (editorial)
} 
como uma "revista universitária". Como é de praxe, seu primeiro número traz um programa: o combate aos "novos ídolos que a desorientação mental dominante e as modas importadas espalham cada vez mais nos meios universitários (...) contra o negativismo anárquico ou o materialismo dialético." 82 A campanha de ataque aos professores Leônidas Resende, Hermes Lima, tornam mais evidente este caráter combativo. A segunda frente de trabalho é a de formação, na qual a defesa do catolicismo torna-se mais explícito:

Formar o espírito universitário, na base das nossas virtudes tradicionais como povo católico e latino-americano.

Formar as nossas inteligências com a substância de doutrinas sadias. Formar o nosso caráter sobre o fundamento de princípios morais e espirituais intangíveis. (PLANO, 1934, p. 1).

O texto repisa algumas temáticas clássicas do anticomunismo do período, como a associação entre nacionalismo e religiosidade, por um lado, e do comunismo com um caráter nocivo, deletério à saúde e progresso da nação. Ao tratar da defesa de uma "cultura verdadeira", em seus próprios termos, a ser defendida de seus inimigos, como um dos objetivos do grupo, o texto expõe o caráter de enfrentamento do grupo em relação aos outros grupos.

Vida dá indícios de como se produziam interessados em participar no Centro Dom Vital durante a década de 1930, através de um processo cuja ênfase consistiu na formação de uma alternativa tida como "culturalmente superior" de catolicismo, intelectualizada, a ser traduzida pelas equipes sociais da Ação Universitária Católica, pela participação em missas ou retiros. Embora tais atividades não estivessem diretamente ligadas ao dia-a-dia de um vocacionado às profissões intelectuais, a presença em atividades deste tipo constituía espaços importantes para a formação de sociabilidades.

A percepção do grupo formado se confirma através das citações cruzadas em muitos dos livros que os autores publicaram durante o período, isto é, da obra de Jackson que faz menção a Leonel Franca, ou do livro de Hamilton Nogueira sobre Jackson de Figueiredo, que também saúda Jônathas Serrano como um escritor de valor, para ficar em alguns exemplos.

\footnotetext{
${ }^{82}$ PLANO de Ação, Vida, Ano I n. 1, p. 1, abr. 1934. (editorial)
} 
Deve-se acrescentar a estes nomes aqueles que ingressaram no Centro após a morte de Jackson de Figueiredo, portanto já na presidência de Amoroso Lima. Uma de suas principais criações foi a Ação Universitária Católica, uma espécie de "centro de formação" de novos vitalistas, a tal ponto que o regulamento deste permitia aos aucistas tornarem-se novos membros automaticamente, depois de terminado seu estudo. Havia uma simetria estrutural entre as duas instituições: as comissões da AUC eram organizadas de modo paralelo às do Centro e sua coordenação ficava a encargo dos vitalistas. No ano de 1933, por exemplo, as coordenações e as comissões foram, respectivamente: Sobral Pinto para "Ciências Sociais"; Amoroso Lima, para a "Ação Social"; Hamilton Nogueira para "Operários e Estudantes" e Claudio Ganns para "Redação e Propaganda". 83

Esta última comissão consistia quase exclusivamente na redação de uma revista, a Vida, publicada entre 1935 e 1937 e dotada de uma equipe enxuta e cujos autores estavam presentes em todos os números da revista com pelo menos um artigo. Nela é possível enxergar o efeito do Centro sobre os homens em processo de formação intelectual e profissional. A respeito do misto de vontade de afirmação e ingenuidade que marcam a revista, Raja Gabaglia comentaria alguns anos depois:

Vida, na qual, de 1933 a 1937, sem solução de continuidade, colaborou a elite católica das Escolas Superiores, era bem uma revista de moços, movimentada, colorida e atrevida. Era engraçado ver como aqueles adolescentes se atiravam ali à discussão de todos os grandes problemas contemporâneos. Defendiam a Religião com ingenuidade e fúria, e transbordante amor. Clamavam a tempo e a contratempo - e como estavam na idade por excelência inconformista, raro o número em que não vinha algum artigo tentando derrubar veneráveis tabus. Alguns notáveis escritores levavam a ousadia ao ponto de pretender rebater as opiniões de respeitáveis "devotas" em matéria de arte religiosa - empreendimento evidentemente superior às mais aguerridas forças humanas! (GAB AGLIA, 1962, p. 305).

O contraste entre o exemplo escolhido por Raja Gabaglia e a associação com a ideia - como se esse fosse o maior ato de rebeldia possível nesta idade -- e indisciplina dos autores da revista serve de exemplo a contrapelo de como a revista (e, por extensão,

\footnotetext{
${ }^{83}$ AÇÃO Universitária Católica. Correio da Manhã, Rio de Janeiro, 02 jun. 1933. Academias e escolas, p. 8.
} 
a própria Ação Universitária Católica) era um espaço de aprendizado do ethos de um vitalista, de quais as leituras e opiniões permitidas no interior do grupo. Ou seja, em uma declaração bem humorada e descontraída, Raja Gabaglia apresenta ao leitor os limites estreitos nos quais os aucistas poderiam atuar para favorecer o projeto de inserção do vitalismo nos embates do período. A Ação Universitária Católica representou um espaço de ensaios, na tentativa de inserir-se com destaque na lógica de produção de textos e de posicionamentos aos quais se submete o grupo de aucistas. A leitura contínua da revista não indica nenhum questionamento aberto à atuação do Centro Dom Vital ou da hierarquia católica.

Entre as mulheres que frequentaram o Centro, poucas deixaram registro, e entre elas se destaca Lúcia Pereira e Stella de Faro. Faro coordenou a Seção Feminina da Confederação Católica por vinte e dois anos e foi também funcionária do Ministério da Saúde e da Educação de Capanema. Neste órgão, trabalhou tanto interna quanto externamente para a ocupação de espaços sociais pelos católicos; por exemplo, realizou a Páscoa dos Funcionários em 1944, para o regozijo de Capanema, sentimento transmitido por carta a Tristão de Athayde. Ela também obteve do Ministério a autorização e o incentivo para a criação de cursos de Serviço Social, no qual as mulheres poderiam obter um diploma profissional e eram treinadas para garantir os "valores familiares" mesmo nos casos de maior carência e desamparo. ${ }^{84}$

Entre os homens, houve uma geração de jovens aucistas que abraçou a vida eclesiástica, assumindo trajetórias de destaque no interior da hierarquia eclesial ou da ordem na qual ingressaram. A trajetória adulta de dois deles demonstra a importância da Ação Universitária Católica para a formação de novos homens para a Igreja. Nelson de Almeida Prado e José Carlos Gouvêa Isnard se tornaram monges beneditinos depois de frequentar a Ação Universitária Católica e colaborar por diversos números da revista. $\mathrm{O}$ primeiro assumiu o nome de Dom Lourenço e foi o reitor do Colégio São Bento no Rio de Janeiro, onde ficou conhecido pelo rigor da disciplina e a defesa do método tradicional do colégio. Gouvêa Isnard se tornou Dom Clemente e sagrou-se bispo de

${ }^{84}$ MESQUIDA, Peri. A educação na restauração lemista da igreja: a missão de Tristão de Athayde e Stella de Faro no Ministério da Educação e Saúde Pública - 1934-1945, Rev. Diálogo Educ., Curitiba, v. 9, n. 27, p. 279-295, maio/ago. 2009. 
Nova Friburgo em 1960, permanecendo nesta condição por vinte e quatro anos. Durante todo este período, foi uma das principais referências na reforma litúrgica, empreendida no país para sinalizar aos fiéis as mudanças no perfil da Igreja.

Além do perfil dos frequentadores do Centro, é relevante levar em consideração os locais onde os encontros aconteciam, com seu entorno e o sentido que a ocupação daquele espaço possuía no cenário urbano. Um exemplo interessante das possibilidades abertas por este tipo de trabalho é a pesquisa de Carlos André Silva Moura ${ }^{85}$ sobre os intelectuais católicos do Recife, que transitavam no entorno da Faculdade de Direito do Recife. Próximo à faculdade, havia o Café Lafayette e, entre os dois, algumas ruas por onde perambulavam os estudantes e diversos outros grupos de letrados - funcionários públicos, jornalistas ou profissionais liberais. A existência destes espaços é o que permitia que trocas culturais entre os grupos se desse com a frequência necessária para formar laços de solidariedade. Os cafés propiciavam momentos de troca de opiniões sobre política e religião ea combinação de estratégias para atuar em conjunto. Eles também serviam de interface no contato dos estudantes com a sociedade recifense, que transitava por estes mesmos espaços.

Existe um diálogo intenso entre os intelectuais do Recife e os do Rio de Janeiro: Amoroso Lima e Figueiredo tinham colunas publicadas frequentemente no Diário de Pernambuco, as quais se tornavam munição nos embates entre os pensadores católicos e os leitores de Marx, a acusarem os primeiros de defender as causas dos operários apenas com promessas, sem resolver de fato sua situação de pobreza (MOURA 2012, p. 124) ${ }^{86}$. Ao tomar posse do cargo de interventor do Pernambuco, Agamenon Magalhães empregou diversos destes estudantes católicos em cargos de confiança. Essa informação permite pensarmos na reprodução de trajetórias ocorridas na capital federal em Pernambuco, algumas das quais noticiadas inclusive no Rio de Janeiro ${ }^{87}$.

\footnotetext{
${ }^{85}$ MOURA, Carlos André Silva de. Fé, Saber e Poder: os intelectuais entre a restauração católica e a política no Recife (1930-1937). Recife: Prefeitura Municipal de Recife, 2012.

${ }^{86}$ Um terceiro grupo cuja importância não pode ser ignorada é o dos defensores de Tobias Barreto e Sílvio Romero.

${ }^{87}$ CENTRO D. VITAL de Recife, A Ordem, jul. 1935, p. 87-89.
} 
A sessão inicial do ano de 1935 registra a liderança do presidente do Superior Tribunal de Pernambuco, desembargador Felisberto Pereira. ${ }^{88}$ A relação com autoridades era algo estabelecido; em 1931, foi a partir de um relatório produzido pelo secretário do Centro Luiz Delgado, que o Secretário da Educação do Estado e o Diretor Técnico da Instrução instituíram o ensino religioso nas escolas, assunto que segundo a reportagem já havia motivado diversos membros do Centro Dom Vital a realizar comícios em praças públicas. Em 1933, as atividades do Centro deram lugar ao trabalho da Liga Eleitoral Católica, da qual resultou a "estrondosa vitória da eleição do Dr. Barreto Campello para deputado da Constituinte". ${ }^{99}$ Em 1934, novas eleições interromperam as reuniões do Centro para concentrar-se na campanha de Andrade Bezerra, presidente da Liga Eleitoral Católica em Pernambuco, que se tornaria o encarregado de redigir o ante-projeto da Constituição Estadual. Em seguida, foi nomeado Presidente da Constituinte.

Voltando ao Rio de Janeiro, é relevante considerar o local onde ocorriam as reuniões do grupo: a Praça XV, localizada no centro do Rio de Janeiro. Bourdieu (1999) chama a atenção para os efeitos que a localização e a capacidade de locomoção podem ter para definir as áreas nobres da cidade, de modo a concentrar todos os sinais de distinção, de posse de alguma forma de capital material e simbólico. Instituições e pessoas socialmente próximas tendem a ficar geograficamente próximas, da mesma forma que a reunião de todos os segregados sociais em um mesmo espaço serve para aumentar sua segregação.

As reformas urbanas das duas primeiras décadas do século $\mathrm{XX}$ haviam alterado consideravelmente a importância do local ao retirar de seu entorno diversas marcas da cidade colonial e imperial. Instalar o Centro em um sítio que já havia funcionado como Paço Imperial, isto é, como um dos espaços centrais da vida política do país, no século XIX, era representativo para um grupo que pretendia encarnar a história nacional, intrinsecamente católica. Mesmo que a praça já tivesse perdido a primazia entre os espaços públicos da cidade, ainda se situava em frente ao Palácio Tiradentes, inaugurado em 1926 para abrigar o Congresso Nacional. Por suas características, a localização do Centro Dom Vital servia ao propósito de resumir o perfil do grupo: o de

\footnotetext{
${ }^{88}$ Também registram-se a presença do jesuíta Candido Mendes e de Manuel Lubambo.

${ }^{89}$ Idem.
} 
guardiões da história e da identidade nacionais, de onde se deveria concluir que o grupo possuía o direito legítimo de interferir na vida política e cultural do país e, para exercêlo, se instalou em frente ao espaço onde eram definidas as políticas públicas neste período.

Um dos ramos mais afetados pela ação do grupo foi a educação: na visão do clássico Tempos de Capanema ${ }^{90}$, Amoroso Lima teria sido uma espécie de eminência parda no Ministério a partir de 1934, mas seu papel já seria relevante desde seu antecessor, Francisco Campos. Durante ambas as administrações, foram atendidas todas as demandas da Igreja no que dizia respeito à liberdade para criar novas escolas e faculdades ou para intervir na discussão dos currículos escolares. Através da análise das comunicações trocadas entre os ministros e os seus interlocutores diretos (profissionais da educação, secretarias da educação, lobistas como Amoroso Lima), Tempos de Capanema faz emergir o Ministério como um espaço de choques entre interesses distintos.

Neste contexto, o grau de dependência vis-à-vis o jogo político do momento é diretamente proporcional ao grau de importância que se tem dentro da hierarquia em vigor. Os ministros da Educação tiveram que se adaptar ao jogo político do momento e abdicar em grande medida de uma atuação anônima. Nisso constituiu a diferença entre Capanema e Campos, pois este ainda acreditou que seria possível impor em certa medida um projeto político próprio ao seu campo de atuação. Capanema emerge da sua interação nos bastidores como uma figura frágil do ponto de vista intelectual e muito dependente do auxílio de Amoroso Lima e Carlos Drummond de Andrade para obter o apoio político necessário para seguir no comando.

Não obstante este papel estratégico desempenhado por Amoroso Lima, Tempos de Capanema aponta, junto com outros estudos, como o de Maria Hermínia Tavares de Almeida ${ }^{91}$, para os limites em sua capacidade de influenciar nas decisões do ministério. Entre os professores contratados para a Universidade do Brasil, os indicados por Amoroso Lima (incluindo os vitalistas Sobral Pinto, Tasso da Silveira, Hamilton

90 SCWARTZMAN, Simon; BOMENY, Helena Maria Bousquet; COSTA, Vanda Maria Ribeiro. Tempos de Capanema. São Paulo: Paz e Terra/Editora FGV, 2000.

91 ALMEIDA, Maria Hermínia Tavares. Dilemas da institucionalização das ciências sociais no Rio de Janeiro. In: MICELI, Sergio. (Org.). História das Ciências Sociais no Brasil. São Paulo: Editora Sumaré, v. 1, 2001, p. 223-256. 
Nogueira, San Tiago Dantas e Everardo Backheuser) formam apenas o terceiro maior grupo. Em cartas enviadas ao ministro, ele protesta contra tal situação e diz que prefere não aceitar o convite para assumir a reitoria da Universidade do Distrito Federal se não puder controlar a indicação de todos os professores. (De fato, diante da recusa insistente, o reitor nomeado viria a ser San Tiago Dantas, próximo a Alceu) O exemplo revela a contrapelo a importância de ocupar os cargos da administração pública com gente da confiança dos católicos.

Dentro desta lógica, o Centro Dom Vital é um importante estoque de possíveis aliados futuros posicionados em postos chave dos órgãos públicos, para cumprir com fidelidade o ensejado para a educação. Outro aspecto desvelado por estes episódios é a diferença de comportamento de Alceu frente ao ministro Capanema em comparação com o Cardeal Leme. Não há registro, mesmo na documentação pessoal de Amoroso Lima, de uma exposição clara de desacordo em relação ao Cardeal. O tom de admiração nutrido por Amoroso Lima chega ao ápice logo depois da morte de seu amigo, em texto vazado pelo sentimento de admiração com o qual define o intuito de seu livro de homenagem póstuma:

Visa apenas guardar a imagem viva, tal como a senti de perto em alguns anos do mais grato convívio. Só peço a Deus que estas pobres páginas, de veneração e cruciante saudade, levem a todos ao menos uma sombra fiel desse homem tão simples, tão bom, que encheu entretanto todo um período de nossa história e cuja lembrança nunca se há de apagar na memória das gerações vindouras. ${ }^{92}$

É possível encontrar a mesma lógica de recrutamento dos membros do Centro no Ministério do Trabalho, que em 1934 passa das mãos de Salgado Filho para Agamenon Magalhães. Este era um frequentador do círculo de Affonso Penna Júnior, por meio de quem conheceu Jackson de Figueiredo ainda em 1924. ${ }^{93}$ Sua escolha para o Ministério do Trabalho representou uma mudança de orientação importante para o órgão, em benefício dos "sindicatos de carimbo", isto é, aqueles com pouca representatividade

\footnotetext{
${ }^{92}$ LIMA, Alceu Amoroso. O Cardeal Leme. Rio de Janeiro: José Olympio Editora, 1943, p. 7 8.

${ }^{93}$ MAGAlHÃES, Agamenon. Jackson de Figueiredo, Gazeta de Notícias, Rio de Janeiro, 02 nov. 1938 , p. 2.
} 
junto aos trabalhadores, mas que atendiam ao propósito de reproduzir o controle do Estado sobre a atividade sindical. ${ }^{94}$

O antecessor de Agamenon, Salgado Filho, levou a cabo uma concepção de Ministério do Trabalho como um árbitro entre as disputas de trabalhadores e patrões. Nesta condição, não pôs em xeque o status dos sindicatos de atuação política mais autônoma em relação ao regime varguista. No período de Magalhães, pelo contrário, estes foram alvos de uma política centrada na sua destruição, que contou com o patrocínio do Estado e o apoio de todas as instituições conservadoras do país, antecipando as condições necessárias para a implantação do Estado Novo.

No início de 1937, tendo Agamenon Magalhães cumprido sua missão de ampliar o controle do Estado na estrutura sindical, foi nomeado interventor em Pernambuco. Em seu novo posto adotou o hábito de atrair os vitalistas de Recife para trabalhar para ele. Em seu lugar, no Ministério do Trabalho, foi apontado Waldemar Falcão, que já havia sido membro da AUC e parlamentar durante a Constituinte de 1934, momento em que se destacou pela defesa das reivindicações do Centro.

Castro Gomes se utiliza de um discurso de Falcão no Congresso Eucarístico de Belo Horizonte (1936) para demonstrar seu apego às causas católicas. Falcão trouxe consigo aucistas para assumir importantes cargos no Ministério do Trabalho, como Luís Augusto do Rego Monteiro ${ }^{95}$, nomeado para a Diretoria Nacional do Trabalho. Monteiro já havia trabalhado no Ministério por convite de Oliveira Vianna e fez parte da comissão de procuradores do trabalho que elaboraram a Consolidação das Leis do Trabalho. Ainda no tocante aos exemplos de vitalistas que vão para os órgãos da

\footnotetext{
${ }^{94}$ Tanto esta como as demais informações sobre o Ministério do Trabalho constituem o tema de reflexão de: GOMES, Angela de Castro. Silêncio e orações: as relações entre Estado, Igreja e Classe Trabalhadora no Pós-34. Revista História e Sociedade, Uberlândia, n. 14, v.2, p. 88$111,1987$.

${ }^{95}$ Entre fevereiro de 1935 e julho de 1936, Rego Monteiro publicou cinco artigos em A Ordem sobre assuntos totalmente distintos da questão trabalhista: a caridade cristã, a arquitetura mais indicada para os templos ou a universalidade do Evangelho. Os artigos são o resultado de palestras e cursos proferidos no espaço do Centro Dom Vital. Foi também o primeiro presidente nacional da Confederação Mariana. Em 1937, foi escolhido por Sebastião Leme para fazer parte do Conselho Arquidiocesano dos Homens da Ação Católica. (Correio da Manhã, 06/04/1937). A seu respeito, conferir:
}

MARTINS FILHO, Ives Gandra da Silva. Um pouco de História do Ministério Público do Trabalho. Revista do Ministério Público do Trabalho. Brasília: Ano VII, p. 28-35, 1 sem. 1997. 
burocracia federal, uma passagem pelos Boletins da Coligação Católica Brasileira ${ }^{96}$ nos auxilia a encontrar outros exemplos, como o de Rubens Porto, que se destacou no ramo do trabalho com o operariado. Foi presidente do Círculo Nacional dos Operários Católicos de 1935 a 1937 e autor de diversas obras sobre alguns aspectos da condição operária $^{97}$.

Tendo em vista os dados alistados, apresentam-se algumas características gerais do grupo a seguir. Tratava-se de um grupo quase exclusivamente masculino, no início de sua vida adulta, isto é, no processo de sua formação profissional ou no início de uma carreira que, em muitos casos, contou com a incursão em cargos públicos ou mandatos eletivos. A participação no Centro serviu a uns como base para arregimentar mão-deobra a fim de trabalhar em favor de sua própria candidatura; a outros, como espaço para a formação de amizades, das quais resultariam uma inserção privilegiada nos órgãos administrativos.

Com a exceção de Amoroso Lima e Jonathas Serrano, nenhum deles era proveniente de família abastada ou de laços estreitos com os grupos no poder durante a Primeira República. Os nomes de maior relevo dentro do grupo eram certamente os de Jackson de Figueiredo, Amoroso Lima e Leonel Franca. Em termos de longevidade de herança, talvez o menos importante tenha sido Figueiredo. Com a exceção de Pascal e a inquietação moderna, seus livros não tiveram repercussão para além de seu lançamento. Entretanto, a sua liderança foi inconteste na sua geração, ora configurando o estilo da polêmica como a principal forma de expressão do grupo, ora tentando inserir seus amigos no circuito literário e intelectual. ${ }^{98}$ Franca e Amoroso Lima se destacaram

${ }^{96}$ Da diretoria da coligação, Amoroso Lima era o presidente; Leonel Franca, seu assistente eclesiástico; Perillo Gomes, secretário. Wagner Dutra era o secretário das duas instituições. No Conselho Administrativo, Hamilton Nogueira, Sobral Pinto e Rubens Porto marcam presença. Cf. BOLETIM DA COLIGAÇÃO CATÓLICA BRASILEIRA, Rio de Janeiro, dez. 1936.

97 Além das atribuições referidas, Rubens Porto foi presidente da AUC em 1933 (Correio da Manhã, 02/06/1933, p. 8) e membro do Conselho Arquidiocesano da Ação Católica em 1937. Os livros publicados por Rubens Porto foram: O problema da habitação (1938); A política do estado em face do problema da habitação operária (1938); Tipos de casas populares (1939); Financiamento trabalhista (1939); A legislação do trabalho (1939).

${ }^{98}$ Hamilton Nogueira afirma que foi graças ao incentivo de Figueiredo que ele começou a se dedicar a escrever, pressionado pela necessidade de fornecer artigos à revista que ora ser formava (A Ordem). Figueiredo também utiliza seus escritos sobre literatura para fazer o nome de seus amigos, como foi o caso com Ismael Xavier e Durval de Moraes, para citar apenas dois livros. 
desde sua formação, concluída no exterior; e Amoroso Lima alcançara nome importante como crítico literário, reconhecido dentro e fora da Igreja. Ele havia apoiado o modernismo desde antes da Semana de Arte de 22, interessando-se pela defesa do movimento à carioca, mais modesto em suas pretensões de renovação. Leonel Franca era um professor de secundário e palestrava sobre temas de interesse aos membros da elite mais devotos. Em ambos os casos, sua consagração provinha de funções ligadas à difusão da doutrina religiosa.

Franca e Amoroso Lima possuíam uma disponibilidade de recursos acima da média, originada de uma herança familiar (no caso de Alceu) ou do uso do patrimônio da ordem inaciana (Leonel Franca). Outro personagem importante foi o empresário e poeta Augusto Frederico Schmidt, que adquiriu a editora e livraria pertencente a Figueiredo após sua morte. Na década de 1930, ela passou a abrigar em seu catálogo tanto obras de vitalistas como a poesia de vanguarda produzida pelos modernistas cariocas.

A escolha de Schmidt em abrigar, em sua editora, tanto livros de religião como das vanguardas modernistas dá continuidade à tradição surgida na década anterior, em que simbolistas evocaram simultaneamente a tradição católica e as vanguardas artísticas como elementos de inspiração para seus poemas. Elas dão ensejo a considerações sobre a sequência existente entre os produtores e o produto de suas obras, ou dito de outra forma e inspirando-se nas considerações de Pierre Bourdieu, como os livros também adquirem posições no campo cultural brasileiro, da mesma forma que seus autores mas não necessariamente posições coincidentes. Com efeito, a fortuna critica de uma obra pode mobilizá-la para uma posição distinta daquela a que originalmente estava destinada. Conhecer portanto o universo de publicação dos livros pode ser uma boa maneira de compreender a maneira como eles serão interpretados.

As editoras pelas quais os livros foram publicados constituem um dado importante, na medida em que os gêneros de maior sucesso são reservados às mais consagradas no ramo, por exemplo a José Olympio. Por outro lado, a publicação por um nome de pouco prestígio nos meios intelectuais, mas com forte presença em um mercado específico - como o dos livros religiosos - também ajuda a mapear a posição de tais livros no momento em que são trazidas a lume. Um estudo das editoras pelas quais Amoroso Lima publicou ajuda a pensar no que representou em termos de 
consagração e de inflexões na obra. Ele possui dezessete obras publicadas entre 1922 e 1933, as quais podem ser agrupadas em três fases: uma anterior à conversão em 1928; a outra que se inicia com a conversão e vai até a publicação de obras por editoras menos consagradas: a Civilização Brasileira e a José Olympio, a partir de 1933. E uma terceira fase representada pelos livros publicados pela Editora Agir, a partir de 1944.

Este critério de busca se justifica por critérios próprios aos livros, que aglutinamse em grandes unidades. Antes da conversão, por exemplo, apenas três foram publicados, por duas editoras distintas: a Anuário do Brasil e a Revista do Sol. Nenhuma deles recebeu reedições no momento em que foram publicadas. Nestes livros, sua preocupação se divide por vários temas, mas em nenhum deles está incluída a questão religiosa ou um problema de desordem espiritual do país, como viria a ocorrer no período seguinte. Entre os temas principais da obra, constam a busca por uma identidade nacional que deveria ser expressa pelos escritores, ou mais precisamente o equilíbrio entre um parnasianismo que já começava a dar sinais de cansaço e uma nova expressão artística, ainda indefinida, que Amoroso Lima começou a enxergar a partir da Semana de Arte Moderna de 1922.

No que diz respeito à identidade nacional, o Tristão de Athayde da década de 1920 é um autor que enxerga na identidade nacional a expressão de uma forma de sentir mais do que pensar; uma procura pela naturalidade da expressão artística. A mesma preocupação com a naturalidade que é também digna de nota quando Alceu investe em outros gêneros que mesclam a crítica literária com a biografia, como é o caso do seu primeiro livro publicado, sobre a figura de Afonso Arinos. Do livro a seu respeito é bastante conhecida a "Introdução", primeiro libelo em defesa da crítica expressionista. Menos conhecido é o restante do livro, que descreve um personagem pelo qual o escritor não esconde seu sentimento de admiração pela simplicidade, seu apego à terramãe e sua espontaneidade. Descrever Afonso Arinos por meio destes traços é significativo porque também seria possível recordar-se que ele foi um homem de letras, com assento na Academia Brasileira de Letras e largos períodos de estadia em Paris e outras cidades europeias. Alceu escolhe construir um herói capaz de unir o cosmopolitismo e a habilidade literária com a naturalidade dos gestos, sentimentos e ações.

Estes são elementos importantes para se pensar no molde que Amoroso Lima adotará após a conversão, na qual é possível enxergar a centralidade da noção de 
natureza humana. Na religião, na sociologia, na política ou na literatura, toda atividade do espírito deveria tender a realizar ao máximo este projeto natural. A presença de Tomás de Aquino como citação constante nestes livros também ajuda a explicar a ênfase na natureza humana e a estratégia adotada por Amoroso Lima: buscar a finalidade de cada uma das ciências, que se resume a realizar em sua plenitude algum aspecto dessa natureza. Assim, se a política é a arte de fazer frutificar os grupos que constituem as associações naturais do homem em sociedade, a ciência social reserva para si o conhecimento técnico necessário para fazer valer os princípios gerais que a política estabeleceu. De modo semelhante, a literatura -- como todas as outras artes -são ferramentas de busca e de expressão da grande verdade fundamental, a religião.

Após assumir o papel de liderança do laicato católico em 1928, os primeiros livros de Amoroso Lima ainda são voltados para a crítica literária, mas a estratégia de publicação se altera radicalmente, com a opção de trabalhar com a editora do próprio Centro Dom Vital, de onde saíram oito livros. A estes se somam outros quatro livros, editados por Augusto Frederico Schmidt, que acolhia em sua livraria os vitalistas para horas extras de discussão. A publicação dos livros de Tristão por tais editoras constituiu uma tentativa de transferir seu prestígio para a editora do grupo ou alguém próximo, como é o caso de $\mathrm{Schmidt}^{99}$. Além delas, há duas coletâneas de artigos publicadas no jornal integralista A Razão transformadas em livro pela Spínola \& Fusco.

Ao percorrer uma temática bastante vasta, incluindo manuais de Economia, Direito, Sociologia, obras sobre a História da Igreja ou sobre temas candentes de seu período, tais como as inovações pedagógicas propostas pela Escola Nova ou a ascensão da classe média urbana, Tristão mantém o tom de quem deseja fincar as bases de novas formas de fazer ciência a partir de paradigmas católicos, criando assim um conceito de "boa" ciência e "má" ciência. Por se tratar de obras introdutórias, elas planejavam atingir um público mais amplo. Seus livros pretendem ser manuais gerais sobre algum ramo das ciências humanas, a partir de seus princípios mais básicos, fazendo a figura de um leitor que desconheça por completo o que se produziu nesse campo para iniciar seu argumento a partir da terra arrasada. Aos livros que reúnem os artigos publicados durante o período caberia o papel de servir como elemento prático de demonstração das teses apresentadas nos manuais.

\footnotetext{
${ }^{99}$ Além de publicar poemas seus na revista A Ordem, Augusto Frederico Schmidt frequentava suas reuniões e abrigava em sua livraria cafés animados com a turma dos vitalistas. Schmidt publicou três livros de Tristão entre 1931 e 1933.
} 
$\mathrm{Na}$ maioria das obras que publicou pela Civilização Brasileira e pela José Olympio, Amoroso Lima abdicou do estilo de grandes obras de introdução às ciências humanas para investir em coletâneas de textos menores e mais localizados em sua temática. Por exemplo, os livros publicados pela José Olympio são em sua maioria republicações de artigos nos jornais ${ }^{100}$ ou textos escritos para outras ocasiões, com outros propósitos. ${ }^{101}$ Meditações sobre o mundo moderno, de 1942, quer investigar a crise que Amoroso Lima acredita se abater inescapavelmente sobre a sociedade de seu tempo. Ainda de acordo com Amoroso Lima, os motivos desta crise seriam a distância entre a sociedade contemporânea e a cristã, com os valores definidos pela Igreja. Tal oposição recebe um sentido ainda mais vivo depois do início da $2^{\mathrm{a}}$ Guerra Mundial, como demonstra a passagem abaixo:

\begin{abstract}
Nem os Acontecimentos, por si sós, nem as soluções meramente humanas da Inteligência, podem trazer aos tempos modernos uma solução para o Drama em que se acha envolvida. Só a Verdade liberta, como nos diz a própria Sabedoria Divina. Só a Voz da Verdade, portanto, que é suave e serena, pode salvar os tempos modernos da tragédia dos Acontecimentos e da angústia das Inteligências. Esse o sentido das páginas que aqui deixo à meditação dos meus contemporâneos. ${ }^{102}$
\end{abstract}

Conclusão semelhante será aquela alcançada pela Crise do Mundo Moderno, de Leonel Franca, cuja análise será feita no capítulo sobre os gêneros apologéticos. O fato de o grupo se consagrar através da produção de obras tidas como de segunda grandeza não pode ser compreendida como uma opção apriorística, mas como em parte o resultado da frustração de planos para a publicação em gêneros mais consagrados. Este parece ser o sentido dos investimentos destes autores na crítica literária, por exemplo, as colunas que Serrano manteve em A Ordem e na Revista Social. Franca, por sua vez, obteve um sucesso considerável com seu manual Noções de História da Filosofia, e suas diversas reedições desde a década de 1920. Mesmo assim, esta foi a única obra desse tipo que produziu.

\footnotetext{
${ }^{100}$ Como é o caso de Meditações sobre o mundo moderno.

${ }^{101} \mathrm{O}$ Cardeal Leme é um livro totalmente atípico, escrito em homenagem quando da morte de dom Sebastião; Pela União Nacioinal reúne três discursos feitos durante o Congresso Nacional Eucarístico, ocorrido em São Paulo, em 1942.

${ }^{102}$ LIMA, Alceu Amoroso. Meditação sobre o Mundo Moderno. Rio de Janeiro: José Olympio Editora, 1942, p. X-XI.
} 
A preocupação com a divulgação dos escritos permite pensar nas duas frentes de atuação do grupo, que não se voltava exclusivamente para a produção intelectual em seu mais alto nível, mas destinava-se também aos "trabalhadores em massa" da educação e do jornalismo, estratégicos para se pensar na formação de uma opinião pública favorável aos anseios da hierarquia católica.

Em resumo, a produção livresca difere bastante entre os autores. Por um lado temos Amoroso Lima, com sua impressionante marca de trinta e cinco publicações nacionalmente $^{103}$ entre 1922 e 1945. De outro lado, um número bem maior de autores com uma quantidade menor de obras, como Hamilton Nogueira (seis obras ${ }^{104}$ ) e algumas exceções, como a de Sobral Pinto, que não escreveu nada. Existe também uma grande diversidade temática, cabendo a Amoroso Lima a primazia de haver escrito sobre uma variedade de temas inigualável. Tendo em vista todos estes aspectos, cabe a pergunta: em que medida é possível falar do grupo como um produtor em conjunto? Os escritos dos vitalistas possuem de fato algum efeito uns sobre os outros?

A reposta a tais perguntas pode ser positiva quando se observam algumas características em comum, por exemplo a referência à validade da fé como o ponto de chegada de todo o raciocínio do grupo. Quando Hamilton Nogueira redigiu em seus Ensaios de biologia um livro que pretendia ser um modelo de como produzir uma ciência católica da vida, ou quando Leonardo van Acker definiu a filosofia a partir de neoescolásticos modernos (Cardeal Mercier ${ }^{105}$ e Jacques Maritain à testa) e reportou a filosofia à sua relação com a teologia, estes autores subordinavam a ciência à fé.

À parte esta característica, há também livros nos quais essa categoria de livro apologético é mais marcada, como é o caso de Perillo Gomes, que escreve Penso $e$ Creio para defender sua opção de fé. Ele enumera as razões pelas quais acredita que a fé católica é superiora a todas as outras e como não pode haver conflito entre a "verdadeira" ciência e a fé, pois ambas se complementam e se valorizam. Escrito em um estilo exageradamente pomposo - o que talvez ajude a compreender sua parca repercussão -- o livro resume o espírito da época na tentativa de unir ciência e religião

\footnotetext{
${ }^{103}$ Nesta contabilidade não foram incluídas obras como Repercussões do Catolicismo, livreto publicado pelo Centro D. Vital de S. João d'El Rey em 1932 e que consiste na transcrição da palestra de Amoroso Lima nesta cidade.

${ }^{104}$ Doutrina da ordem (1925); Jackson de Figueiredo, doutrinador católico (1928); Freud e a renovação psicológica (1930); Ensaios de Biologia (1934) - este em colaboração com Amoroso Lima; Dostoiewski (1935); e Educação sexual (1941).

${ }^{105} \mathrm{O}$ Cardeal Mercier foi um filósofo belga.
} 
de modo vantajoso a esta última, que passa a ser vista como a fiel depositária da legitimidade científica.

Os escritos de Gomes sintetizam a opinião geral do grupo, mas cada autor formula as razões de sua fé de maneiras diversas. O próximo capítulo analisará mais a fundo estas respostas, a começar por aquele que as formulou de maneira mais completa e antenada com as questões centrais do debate intelectual brasileiro no período: Alceu Amoroso Lima. Esta análise ajudará a compreender porque ele foi o porta-voz do grupo. 


\section{Capítulo III: A Crítica Literária}

"O mistério é o grande adversário do homem na natureza."

(Tristão de Athayde, 1923)

"Nossa civilização só pode nascer da aliança íntima e harmoniosa de um espírito científico positivo e um espírito religioso positivo."

(Tristão de Athayde, 1930) 
As duas epígrafes formam parte de uma série de crônicas literárias de autoria de Tristão de Athayde e demonstram a alteração no seu modo de enxergar as relações entre a ciência e a fé. A primeira epígrafe faz parte de uma argumentação para demonstrar que não existe transcendência, apenas fatos desconhecidos pela ciência. A segunda epígrafe foi escrita sete anos depois da primeira e revela uma visão diametralmente oposta. Ele ainda reconhece a importância do progresso científico, com a diferença de que sua capacidade estaria restrita ao aspecto material da existência. Mesmo quando houvesse a satisfação plena das necessidades físicas, a transcendência seria um fato inelutável da existência humana e a resposta a ela só poderia advir da doutrina da Igreja. O uso do termo "positivo" para designar tanto o espírito científico quanto o religioso mostra que para Tristão não haveria contradição entre os dois termos.

O desafio deste capítulo será compreender como se deu a passagem de uma epígrafe à outra, isto é, como ele transita entre os extremos na relação entre ciência e fé. E como ele raciocina a conversão ao catolicismo. Ademais, a conversão de Jackson será examinada, pois ele constituiu outra matriz a partir da qual os outros vitalistas pensaram em si mesmos. A crítica literária de ambos foi uma atividade desenvolvida cotidianamente durante um largo tempo e permite compreender o posicionamento destes autores frente aos outros críticos literários do período e seus principais temas de interesse.

Quando Amoroso Lima estreou sua coluna "Bibliografia", elegeu como um dos problemas centrais a formação de uma cultura nacional. Em seu primeiro texto, de 17 de junho de $1919^{106}$, definiu sua atividade jornalística semanal como uma modesta contribuição para acelerar a formação de uma cultura brasileira superior. Em virtude de nosso atraso cultural, seria necessário que um exército de críticos, jornalistas e professores agissem por gerações em um trabalho lento para atingir os seguintes objetivos:

Distinguir o que de eterno deixaram os clássicos, admirar sem submissão antigos e modernos, descobrir virtudes e belezas acima das fronteiras e nacionalidades, manter o contato com as ideias $\mathrm{e}$ preocupações contemporâneas, isolar o fio da tradição, sempre de olhos presos na cultura, para a formação de uma individualidade nacional. E aqui nesta coluna de jornal, ansiosos por trazer a nossa

106 LIMA, Alceu Amoroso. "Iniciando". In: Estudos literários. Rio de Janeiro: Companhia Aguilar Editora, v.1, 1966, p. 61-63. [Coleção Biblioteca Luso-Brasileira] 
pedra ao formoso edifício da nossa cultura, guia-nos a esperança de que nos compreenderão, relevando a ousadia do empreendimento pela grandeza do objetivo, todos aqueles que amam esta terra e confiam neste povo. (LIMA, 1966, 63)

Seu programa de crítica literária exibiu desde o início a marca de um nacionalismo que encontraria, poucos anos depois, companhia nos escritos dos modernistas, também eles preocupados com a valorização de uma cultura que pudesse elevar o Brasil no teatro de nações. Existe aqui um claro diálogo com as preocupações sobre a educação expressas ao longo da década de 1920 por livros como À Margem da História da República, conforme já comentado em trecho anterior deste texto. Sendo a educação o instrumento por excelência de formação de uma nova elite, era necessário pensar no que deveria ser ensinado. Para isso é que se voltavam os olhos de Alceu, que quis fazer de seu trabalho uma espécie de pauta da cultura nacional.

O problema de definir nossa identidade se traduziu também por uma leitura estética a respeito do tipo de poesia produzida no país durante o período. Em se tratando de um crítico literário em busca de projeção, Tristão tomou uma atitude corajosa ao escolher nomes consagrados do parnasianismo como ponto de embate. Sobre Coelho Neto ${ }^{107}$ Tristão é bastante severo, a despeito de ser este autor um dos mais vendidos e aclamados no período. Seus escritos são comparados a "um brocado suntuoso vestindo uma imagem tosca"108. Seu trabalho exagerado com a linguagem faz perder a naturalidade de estilo, defeito presente tanto em sua produção literária quanto nos discursos políticos. Para Tristão, Coelho Neto poderia ser um grande poeta se voltasse a escrever sem tanta afetação e sem a carga excessiva de referências à cultura grega. Em

${ }^{107}$ Coelho Neto (1864-1934) completou seus estudos secundários no Rio de Janeiro, onde destacou-se primeiramente como um abolicionista que escrevia frequentemente para os jornais a partir de 1886. Conviveu com o grupo da boemia literária (os parnasianos como Olavo Bilac e Paula Ney) até 1890, quando se transferiu para Campinas. Em 1893, voltaria ao Rio de Janeiro, onde viveu até o final da vida, deixando uma obra monumental de 112 volumes publicados, 5 obras inéditas, 4 não-terminadas e 9 consideradas perdidas. Conforme:

COELHO NETO. In: DICIONÁRIO literário brasileiro, v. 2. São Paulo: Saraiva, 1969, p. 364365 .

Nas palavras de Antonio Candido, Coelho Neto foi um "escritor probo e laborioso, de uma espantosa fecundidade, capaz de construir romances interessantes, quando não ficavam sufocados pela exuberância da sua prosa, na qual se infiltram elementos 'decadentes' finisseculares." Retirado de:

CANDIDO, Antonio. Iniciação à literatura brasileira. São Paulo: Humanitas, 1999.

${ }^{108}$ LIMA, Alceu Amoroso. "Coelho Neto". In: Estudos literários. Rio de Janeiro: Companhia Aguilar Editora, v.1, 1966, p. 79. [Coleção Biblioteca Luso-Brasileira] 
relação a Olavo Bilac ${ }^{109}$, o julgamento é mais positivo. Seu livro de poemas Tarde é visto como o resultado de um bom equilíbrio entre a espiritualização da linguagem, capaz de transmitir os sentimentos mais sublimes, e o trabalho com a forma.

Não foram apenas as correntes consagradas na literatura de seu tempo que receberam reprovação, nem mesmo as mais duras. A leitura de André Breton (Manifeste du surréalisme, que Alceu traduz como "supra-realismo") desperta a ira em razão das premissas sobre a natureza humana presentes neste texto, para o qual reserva suas piores palavras em duas crônicas, publicadas nos dias 14 e 21 de junho de 1925. Elas revelam um tipo de raciocínio sobre a arte e, em grau mais profundo, sobre a existência humana, que ajudam a compreender as razões que levaram Alceu a se aproximar da religião católica.

Para ele, era necessário impor limites aos experimentalismos, pois a natureza humana seria em sua essência racional, e isso era o que deveria ser expresso pela arte. Por tais motivos, apresentar uma estética que propusesse libertar o ser humano do domínio da razão parecia a Alceu "uma infecção literária natural, que correspond[ia] ao estado de espírito de toda uma época" ${ }^{110}$. Escolhendo um conjunto de citações de estudiosos da Idade Antiga e da Medieval, Alceu constrói uma imagem idílica da vida social e enfatiza os princípios da Ordem e do senso de comunidade como determinantes para uma boa sociedade. Ao contrário de tal imagem, as novidades trazidas pela filosofia e pelas artes a partir da modernidade consagraram a prerrogativa dos indivíduos como seres autônomos no Direito, na Arte ou na Religião.

Alceu se pergunta qual poderia ser a garantia de estabilidade política, de justiça ou de beleza em uma situação como esta, na qual tudo depende de vontades instáveis por natureza. Haveria segundo ele duas tendências igualmente importantes no tempo presente, ainda que opostas: a primeira é a de homogeneização, a da construção de uma unanimidade sempre perigosa e provavelmente ditada pela força; a segunda é a de desagregação dos laços sociais, pois se cada indivíduo é uma entidade fechada em si mesma, não havia espaço para a formação de solidariedades.

Os defeitos do surrealismo não se resumiriam, entretanto, a seu conceito de sociedade, incluindo sua definição de natureza humana. A ideia do subconsciente como aquele que rege o comportamento humano consiste para Alceu em um equívoco de

${ }^{109}$ LIMA, Alceu Amoroso. « Olavo Bilac », In: Estudos literários. Rio de Janeiro: Companhia Aguilar Editora, v.1, 1966, p. 81-92

${ }^{110}$ Estudos literários. Rio de Janeiro: Companhia Aguilar Editora, v.1, 1966, p. 904. 
consequências altamente nocivas à expressão artística, entendida como a busca racional pelo belo. A psicanálise havia proporcionado uma importante contribuição ao demonstrar a existência do subconsciente, mas essa descoberta não se encerrava em si mesmo; era preciso seguir adiante e desenvolver um instrumental teórico capaz de confirmar o domínio da racionalidade na natureza humana. O texto também apresenta uma visão negativa sobre o presente, a partir da ideia de uma crise de valores a ser enfrentada em todos os âmbitos. Tristão toca pela primeira vez no tema e define o problema em termos de desequilíbrio da força do poder financeiro sobre as democracias modernas:

Revelar uma riqueza não é, de forma alguma, concluir pelo seu predomínio. O dinheiro, a abundância de dinheiro verdadeiro é uma riqueza, não há dúvida. Mas o predomínio exclusivo do dinheiro é a plutocracia que submerge e desmoraliza as democracias modernas. (LIMA, 1966, 909)

O texto revela uma crítica à ordem liberal a partir de um paradigma conservador, de quem lamenta a substituição da hierarquia social determinada pelo prestígio pela força do dinheiro. As antigas regras eram calcadas em características das personalidades de seus portadores, enquanto as riquezas podem ser formadas e perdidas em pouco tempo; elas podem ser reais ou fruto de uma bolha especulativa. Tudo isso torna a ordem social algo completamente irracional. Pelo mesmo motivo que critica o surrealismo, Tristão reprova o movimento pau-brasil e especialmente um de seus próceres, Oswald de Andrade. Lamenta que um dos melhores talentos da nova geração se deixe perder na ilusão de que sua estética representa uma imaginada essência brasileira, quando não passa de uma cópia das vanguardas europeias. Alceu condiciona o sucesso do modernismo à sua capacidade de dialogar efetivamente com seu esforço "de procurar o sangue da terra, o pulso da raça, o segredo da paisagem" (LIMA, 1966, 997) ao invés de reproduzir fórmulas do Velho Mundo.

No bojo das disputas entre os dois, o questionamento das ideias literárias se confunde ao do estilo de vida, pois ambos se acusam em momentos distintos de não serem fiéis na vida ao que pregam em seus escritos. ${ }^{111}$ Os primeiros escritos não prenunciavam esse desdobramento: ainda em 1922, Alceu fez uma crítica bastante

\footnotetext{
${ }^{111}$ Sobre as contradições que Oswald denuncia em Alceu na década de 1930, ver mais adiante neste mesmo texto.
} 
positiva à Semana de Arte Moderna e incluiu o nome de Oswald como um dos talentos promissores. Os Condenados, romance social publicado por Oswald em 1922 e comentado por Alceu em 21 de Janeiro de 1923, recebeu elogios de Alceu por abrir uma nova vertente de realismo social dentro do modernismo.

Como se torna então possível explicar as diferenças entre as opiniões do início de 1923 e as expressas pouco mais de dois anos depois? A resposta a esta indagação pode estar em um comentário extremamente irônico de Alceu sobre os hábitos de Oswald, a respeito do cotidiano daquele que pretendeu ser "o descobridor do Brasil":

Entre as almofadas do seu Cadillac, depois das trufas do Automóvel Club, entre uma partida de mah-jong e a última teoria de Epstein, entre uma carta do Comte Etienne de Beaumont e o exame dos planos do novo sky-scraper do Triângulo, o Sr. Oswald de Andrade senta-se à sua secretária do Ruhlmann, acende o seu cachimbo de Old BondStreet, toma da sua Watermann, invoca os manes de Apollinaire e do citoyen Vaché e põe-se a ensinar poesia brasileira aos caipiras do Cariri e do Garnier! ${ }^{112}$

O espanto que Tristão demonstra na passagem se desdobra em diversas perguntas: como poderia um membro tão típico da aristocracia cafeeira, que se pretendia cosmopolita, querer deixar sua condição social de lado no momento de fazer poesia? Por que afirmar uma barreira completa entre a "autêntica literatura nacional" e a tradição já estabelecida, como se uma pudesse viver sem a outra? Alceu enxerga uma contradição gritante entre o convívio social de Oswald e a postura radical de negação da cultura estrangeira. Esta primeira contradição convive com uma segunda, a da afirmação de uma literatura nacional a partir da importação de vanguardas europeias. Da mesma forma que a cultura nativa precisa reconhecer-se em seu passado para modificar seu presente, não é com sua vida de aristocrata do café que Oswald poderia ditar o que é a realidade brasileira em seus recantos mais escondidos (os caipiras do Cariri) aos frequentadores da livraria Garnier - a mais famosa e mais bem frequentada livraria do Rio de Janeiro, na época.

Se o modernismo literário feito em São Paulo, com suas inovações muito além das desejáveis, não servia de exemplo, onde ele poderia ser encontrado? Teria Alceu

112 LIMA, Alceu Amoroso. Estudos 1925. In: Estudos literários. Rio de Janeiro: Companhia Aguilar Editora, v.1, 1966, p. 999. [Coleção Biblioteca Luso-Brasileira] 
enxergado entre os livros publicados no período algum que lhe servisse de referência? A resposta a tais perguntas indica que, anos antes de assumir a liderança do Centro Dom Vital, Alceu já enxergava em seus nomes alternativas promissoras. Neste sentido, é necessário relativizar a ideia de rompimento estabelecida pelo "Adeus à disponibilidade" e perceber que as condições para o papel que Alceu exerceria após 1928 foram se estabelecendo no período anterior, em uma resposta crítica tanto ao modernismo literário paulista quanto à situação política da Primeira República, em franco processo de deterioração. Em ambos os casos, o grupo do Centro Dom Vital apresentaria uma resposta em afinidade com as opiniões de Alceu e seu julgamento cético em relação ao que considerava um excesso de individualismo.

Em termos políticos, seria este liberalismo exacerbado o responsável pela emergência da questão social. Em crônica de 28 de fevereiro de $1921^{113}$, Alceu teceu comentários a essa questão a partir do livro de Perillo Gomes, Penso e Creio. O primeiro comentário de Tristão é sobre o autor, que representaria uma nova geração de pensadores livres de compromissos com os grupos favorecidos socialmente, e portanto mais capacitados para fazer a defesa do status quo. O mesmo poderia ser dito de Figueiredo.

Este tortuoso raciocínio para comprovar a capacidade destes autores pode ser lido a contrapelo como uma revelação das origens sociais e da falta de inserção destes autores na elite carioca. Esta constatação conduz a uma outra pergunta: por que Tristão sente sua curiosidade aguçada pelos livros? O artigo saúda Figueiredo e Gomes como artífices de uma nova era no pensamento social, na qual a resposta à crise social começava espiritualmente, discutindo as bases filosóficas que sustentam o modo de pensar do homem moderno, isto é, através da crítica ao individualismo e ao materialismo. Ela conheceria seu final quando os empresários deixassem de considerar o lucro como a finalidade da economia, ou quando os trabalhadores enxergassem a importância social de sua produção, e, dessa forma, entendessem como a realização de greves era algo nocivo para eles e para toda a sociedade.

A exigência de uma mudança de comportamento e valores como um elemento para a solução da crise econômica é um fator importante para entender como, posteriormente, a conversão de Athayde se torna possível. Já em 1921 existem registros

\footnotetext{
${ }^{113}$ LIMA, Alceu Amoroso. Primeiros estudos II. In: Estudos literários. Rio de Janeiro: Companhia Aguilar Editora, v.1, 1966, p. 319. [Coleção Biblioteca Luso-Brasileira]
} 
em sua produção da busca por uma solução no terreno dos princípios filosóficos para a organização do trabalho, tema que o ocuparia por toda a década de $1930^{114}$. Portanto, a atração de Alceu pela obra de Perillo Gomes nasce da decisão deste autor de também tratar da questão social como um problema de fé, ou melhor, de falta dela, pois o abandono da crença no Evangelho teria conduzido os proprietários a se deixarem levar por um materialismo que enxergava com frieza o sofrimento provocado em seus trabalhadores. A respeito deste assunto, Perillo declara:

\begin{abstract}
Nós vemos na impiedade a causa do infortúnio de todas as classes e principalmente dos desprotegidos da fortuna. As classes ricas e poderosas libertas do temor de Deus pela ação de um materialismo dissolvente, não cuidam de mais que tirar da vida presente o máximo proveito, a despeito do sofrimento que encontram e que muitas vezes espalham pelo caminho.

Assim, o capitalismo, sem o único freio capaz de o dominar e conter nos seus apetites - a religião - explora o trabalho do pobre com frieza e com desdém. ${ }^{115}$
\end{abstract}

O trecho acima reverbera as críticas tecidas na encíclica Rerum Novarum, de 1891, inclusive no que diz respeito ao papel dos empresários de serem igualmente os responsáveis pela crise e os únicos capazes de resolvê-la. Aos trabalhadores restaria um papel diminuído, mesmo que P. Gomes e Tristão considerem justas as reclamações deste grupo. Se na parte política os dois se aproximam, a leitura se torna mais seletiva quando se trata das relações entre fé e razão, ou entre a religião e a ciência. A este respeito, Tristão não concorda com o raciocínio de Perillo Gomes, o qual separa a realidade em duas instâncias hierarquicamente sobrepostas: a ordem natural, da alçada das "ciências humanas" e a ordem sobrenatural, responsabilidade das "ciências divinas". Ainda segundo ele, da mesma forma como as ordens se sobreporiam, as ciências das quais tratam também, e a verdadeira ciência empírica adquiriria sua validade a partir do momento em que admite seus limites, isto é, em última análise, o mistério sobre a existência humana.

\footnotetext{
114 Em minha dissertação de mestrado, mais precisamente nos capítulo III e IV, trato detalhadamente do pensamento amorosiano sobre a questão do trabalho e sobre como suas obras foram utilizadas em meio às discussões da Constituinte de 1933.

${ }^{115}$ GOMES, Perillo. Penso e creio. Rio de Janeiro/Lisboa: Anuario do Brasil/Renascença, 1921, p. 64 .
} 
Alceu, pelo contrário, ainda exibe uma visão otimista sobre o progresso da ciência na dominação da natureza e na expulsão do campo do desconhecido para territórios cada vez mais distantes:

\begin{abstract}
A natureza é a evidência como é o mistério; entre os dois polos estão colocados os segredos de que, à custa de um longo e inaudito esforço, vai o homem lentamente se apoderando. A ordem sobrenatural, portanto, é a incapacidade do homem em determinar os limites da ordem natural. É mais lógico, portanto, atribuir essa ordem sobrenatural aparente à ignorância fundamental do Homem do que à existência de Deus. O mistério é o grande adversário do homem na natureza (LIMA, 1966, p. 322-323)
\end{abstract}

Alceu admite um contrapeso ao papel declinante do mistério: a necessidade de ordem moral e social conduziria os seres humanos a buscarem o consolo da religião. Portanto, se o Alceu de 1921 é ainda um homem que acredita plenamente no progresso da ciência, demonstra em contraponto uma abertura para o diálogo com os portadores de alguma crença no sobrenatural, como é o caso de sua resenha de 09 de junho de 1922 , sobre Jackson de Figueiredo e seu livro Pascal e a inquietação moderna. Nela desenhase a imagem do filósofo francês ${ }^{116}$ como alguém que poderia pautar o debate brasileiro de seu período e, dessa forma, trazê-lo para um terreno favorável a Figueiredo. Visto de outra forma, Jackson descreve a si próprio ao definir a imagem de Pascal como um filósofo que pecou por alguns excessos, como o jansenismo ${ }^{117}$, mas que nunca deixou de acreditar na Igreja Católica como a realidade última do homem. E que tal característica se tornou o legado deste filósofo.

A escolha por escrever uma obra sobre Pascal, quando outros autores eram os temas mais comuns nos escritos sobre doutrina católica, é uma aposta que precisa ser melhor esclarecida. Ela pode ajudar a compreender o público ao qual se destinava a obra: distante das discussões sobre a filosofia católica francesa do período e próxima da

${ }^{116}$ Blaise Pascal foi um filósofo matemático e inventor que viveu na França entre 1623 e 1662. Entre outras coisas, escreveu sobre a conveniência de se valer da crença da existência de Deus e assumiu posturas teológicas que o aproximou do jansenismo (ver próxima nota).

117 "Doutrina teológica e filosófica baseada no Augustinus, obra de publicação póstuma (1640) do bispo holandês Cornélio Jansênio (1585-1638), que negava o livre-arbítrio e afirmava que a graça era um privilégio inato concedido a poucas pessoas. $\mathrm{O}$ jansenismo floresceu principalmente na França nos séculos XVII e XVIII, tendo corno centro o convento dc Port Royal, em Paris, onde se instalaram os seus defensores mais acirrados. entre os quais Antoine Arnauld, Pierre Nicole e Blaise Pascal. Os jansenistas, que além de tudo adotavam uma moral rigorosa, foram combatidos pelos jesuítas e condenados corno heréticos em várias bulas papais." Retirado de: JAPIASSÚ, Hilton; MARCONDES, Danilo. Dicionário básico de filosofia. Rio de Janeiro: Jorge Zahar Editores, 2006, p. 113. 
herança cartesiana. Outros nomes fundamentais da doutrina católica, como Santo Agostinho ou Santo Tomás, não teriam o mesmo impacto de falar a um público escolado em uma tradição de dúvida metódica. Com isso Figueiredo permanece inscrito nos cânones filosóficos já estabelecidos, mas aberto a uma interpretação favorável ao projeto de tornar a Igreja Católica a legitimadora de todas as esferas sociais no Brasil dos anos 1920. Pascal é considerado como o filósofo que respondia à angústia do homem moderno:

Pascal e a angústia são o elemento que mais vivamente agita a consciência contemporânea, sendo causa de primeira ordem, não só da reação espiritualista que vai estrangulando o materialismo moderno, mas também da já tão notada renascença, senão católica de um a outro extremo, pelo menos, cristã, entre as camadas intelectuais superiores, em todo o Ocidente (FIGUEIREDO, 1922, p. 159).

Tristão e Figueiredo compartilham do juízo de que o excesso de valor conferido à riqueza material estaria levando o Ocidente a uma crise, da qual já se notavam os primeiros sinais de resposta a partir de uma nova corrente espiritual. Figueiredo enxerga em Pascal uma resposta possível para suas próprias indagações, que já são em certa medida as mesmas que as suas. Tristão reconhece no filósofo o modelo mais sublime de adoção do catolicismo (LIMA, 1966, 703) -que ele próprio viria a reproduzir alguns anos depois de fazer esse comentário.

Outro dos fundadores do Centro cuja obra merece o olhar atento de Alceu é o de Tasso da Silveira e seu livro A Igreja Silenciosa, objeto da análise do dia 12 de novembro de 1922. Em seu comentário sobre a obra, Alceu demonstra o mesmo movimento pendular que estabelece no caso de Perillo Gomes, de aproximação e distanciamento. De um lado, o elogio à importância de se pensar nas questões religiosas, tal como expresso abaixo:

\begin{abstract}
A um século de dúvida intelectual parece suceder uma era de fé, dentro ou fora dos limites da natureza. Para nós, que, embora iniciando a era nova, ainda trazemos ou trazíamos o espírito impregnado da era anterior, pareciam-nos a ironia e o desdém pela ação a inteligência suprema de viver. Vemos hoje, ou pressentimos, que uma certa covardia intelectual é que nos levava a esse ceticismo integral. ${ }^{118}$
\end{abstract}

118 LIMA, Alceu. Estudos 1922 - XXI. LIMA, Alceu Amoroso. Estudos literários. Rio de Janeiro: Companhia Aguilar Editora, v.1, 1966, p. 739-740. Comentários a: 
No trecho acima não há indícios de que a religião católica seria adotada, mas tampouco existe espaço para o espírito da Belle Époque, de despreocupação e ceticismo. Seis anos antes da conversão, sentia-se a necessidade de crer em algo. Mas em quê? Ainda sem localizar-se no interior da fé católica, Tristão reconhece na aurora de uma geração preocupada com a religião, junto com a nobreza do trabalho e a inteligência da ação, a capacidade de salvar o país da sua situação atual de "preguiça intelectual". Há, porém, o distanciamento de quem enxerga na religião a satisfação de uma necessidade humana, sem que isso signifique crer em algo para além do visível:

Não duvido que as religiões possuam a "utilidade" fundamental de apoio à moral social, como argumenta o Sr. Tasso da Silveira em outro fragmento da parte final do seu livro, mas tudo isso o que indica é que as religiões são a obra fundamental do homem sobre a terra, fundamental mas humana (LIMA, 1966, p. 742).

A religião seria apenas o resultado do desejo dos seres humanos por interagir com seus semelhantes, uma necessidade de sociabilidade, saudável em si mesmo, mas de nenhuma maneira transcendental, como desejava comprovar Tasso da Silveira. Sobre este autor, Alceu ainda comentaria outro livro seu de poesia (Alegorias do homem novo) para identificar no tratamento que ele confere à religião um modo de comparação com o continentalismo americano de Ronald de Carvalho, a busca de uma nova linguagem brasileira de Mário de Andrade ou a sedução das coisas do dia-a-dia na obra de Manuel Bandeira. Todas essas seriam temáticas importantes de inspiração dos poetas, mas não constituiriam o cerne de sua atividade. Para tais autores, a religião poderia servir até de musa inspiradora, mas não como seu elemento definidor.

A religião assumiu maior relevância na visão de mundo de Amoroso Lima a partir da primeira série de Estudos, reunindo textos publicados entre 1926 e 1927 . Em meio a uma digressão sobre o tema da disponibilidade, emprestado de Gide, Alceu afirma:

A conservação do espírito sempre livre de toda ligação para estar pronto a receber qualquer ideia nova que chegue - essa noção criou

Tasso da Silveira, A Igreja Silenciosa, Rio de Janeiro, Anuário do Brasil, 1922. Andrade Murici, O Suave Convívio, Rio de Janeiro, Anuário do Brasil, 1922. 
uma literatura de artifício e de diletantismo que faz os artistas perderem "la partie éternelle d'eux mêmes". ${ }^{119}$

O comentário acima aparece em meio a uma discussão sobre as mudanças no espírito europeu após a I Guerra Mundial, mas não se restringe ao Velho Continente. Alceu enxerga na oposição entre o grupo da revista Esprit (recém lançada na França) e a mais conhecida obra de Bernanos, Sob o sol de Satã, uma tensão a ser resolvida também pela cultura brasileira, em formação. De um lado, Esprit enxerga na própria relação de forças sociais nascida do final da guerra as condições para a solução dos problemas do capitalismo, a partir de um plano de revolução social que também não se identifica ao comunismo. Noves fora a indefinição do que seria tal revolução social, persiste o problema de se repensar a sociedade francesa (ou, para Alceu, a brasileira) apenas a partir de um rearranjo das forças já atuantes no presente. Em oposição a essa cena, Sob o sol de Satã proporia segundo Alceu "uma transcendência ao tempo e às superfícies. Expressões do novo sentimento trágico da vida, como há pouco víamos nas cartas inesquecíveis de Cocteau e Maritain.” (LIMA, 1928, p. 144)

Em 1926, Alceu acompanhou com interesse o debate no interior do catolicismo francês e reconheceu em Maritain um de seus principais interlocutores. Naquele momento, a tensão em torno do radicalismo de Charles Maurras e de seu grupo, a Action Française era o tema central na discussão dos católicos do hexágono. Ao encampar explicitamente a opinião de Maritain, ele sinalizou que tampouco considerava a primazia do político - o "politique d'abord" de Maurras - como a melhor alternativa do período.

Além disso, destinou maior espaço aos escritos dos membros de $A$ Ordem e à maneira como eles buscam reinserir a religião católica e a presença da Igreja no seio da discussão social. Quando Hamilton Nogueira publica A Doutrina da Ordem (Rio de Janeiro, A Ordem, 1925), Tristão dedica ao livro uma coluna e estabelece um diálogo entre o livro de Nogueira e o de Júlio de Mesquita Filho, A Crise Nacional (São Paulo, Editora d'O Estado de São Paulo, 1925). O motivo da crônica são as críticas que ambos os autores realizam ao sistema político da Primeira República, com avaliações diametralmente opostas no que concerne às soluções apresentadas. Mesquita pensa que o sistema seria corrigido pela instalação de eleições secretas, as quais contribuiriam para

${ }^{119}$ LIMA, Alceu Amoroso. Estudos. Rio de Janeiro: Edição Terra de Sol, 1928 (1 Série), p. 141. 
o aperfeiçoamento de um sistema liberal-democrático, tido por ele como positivo em sua essência.

Contra esta opinião, Alceu mobiliza Nogueira e sua capacidade de apresentar diretamente o cerne da questão: a substituição das eleições individuais por representantes escolhidos conforme sua profissão, fazendo parte de uma estrutura de Estado centralizada e forte (LIMA, 1928, p. 316). A alternativa apresentada em 1926 já pautam as considerações sobre o tema na década seguinte, quando o corporativismo foi apresentado como a última solução possível para enfrentar uma revolução comunista que, caso contrário, talvez se anunciasse como inevitável.

Alceu elogia a coragem de Hamilton Nogueira em se amparar nos ditames da doutrina da Igreja, sua guia, para se dirigir às consciências "com uma fé que não recua mesmo diante de evocações arriscadas e uma categoricidade que é a força das ideiasação, tão necessárias, por vezes, em nosso meio de inação das ideias" (LIMA, 1928, p. 318-9) Esta é outra inovação entre os comentários de Alceu no período, uma vez que ele enxerga como um fato positivo que a convicção religiosa deste autor seja uma motivação importante para sua atuação política.

Esta, no entanto, ainda peca por falta de um senso prático em suas escolhas, pois permaneceria no plano das "afirmações gerais, sem quase descer ao fato, ao exemplo concreto". A religião de Nogueira é positiva quando oferece uma razão para envolverse na solução dos problemas mais urgentes e concretos do Brasil no período, mas não para escapar deles como em uma fuga. A solução que Alceu prefigura para Nogueira é aceitar a inevitabilidade do regime democrático no continente americano, mas lutar para atenuar seus defeitos a partir da perspectiva aberta pela religião.

O tema das soluções religiosas para enfrentar os problemas do presente ganha força nas séries seguintes de Estudos, como podem demonstrar aquelas escritas durante o ano de $1928,{ }^{120}$ a ponto de transformar aquilo que Alceu enxerga como crítica literária. Seu esforço deixa de ser a apreciação estética do livro e se transforma em uma

\footnotetext{
${ }^{120}$ Esse conjunto foi agrupado em dois volumes e publicado pela editora da revista "A Ordem". A obra consultada é a original do período e nela não há introdução nem referência explicativa sobre a data e local de publicação, do livro em si e dos artigos. Deste modo, utilizou-se como referência para a data o livro Alceu Amoroso Lima (1893-1983): bibliografia e estudos críticos, do Centro de Documentação do Pensamento Brasileiro. A data de publicação informada pelo livro (1930) é a mesma das obras de Riolando Azzi (Os Pioneiros do Centro Dom Vital), Antonio Carlos Villaça (O Pensamento Católico no Brasil) e Leandro Garcia (Alceu Amoroso Lima - cultura, religião e vida literária).
} 
discussão sobre os princípios (explícitos ou não) apresentados pela obra. A partir deste critério, as análises de Alceu constituem dois grupos de obras: as capazes de apontar para a natureza espiritualista da sociedade brasileira e para a necessidade de recuperá-la e as demais, que merecem ser descartadas. Daquela postura inicial de abertura para a compreensão dos autores com base no que eles pensam de si próprios, o crítico se torna dogmático, fechado a outras formas de pensar e escrever diferentes das determinadas pela Igreja.

Há de se levar também em conta uma alteração no perfil dos livros publicados durante o período, com a diminuição na quantidade de romances e obras de poesia produzidas em paralelo ao aumento no número de colunas sobre os problemas sociais do país. O tipo de obra poderia ser um ensaio social de Azevedo Amaral ou Oliveira Vianna ou um livro de apologia como o de Leonel Franca, mobilizado para defender a tese de que todo o clero deveria compreender que sua missão religiosa incluiria tomar parte na discussão política, educativa e intelectual do país. A obra de Franca seria a união de uma justa preocupação apologética com um caráter científico, em uma amostra do rumo que a produção intelectual deveria tomar dali em diante:

Nossa civilização só pode nascer da aliança íntima e harmoniosa de um espírito científico positivo a um espírito religioso positivo. Um resolvendo os nossos problemas materiais básicos, o outro resolvendo os próprios fundamentos dos nossos problemas do espírito.

E por isso mesmo é que obras como esta do P. Leonel, sendo um tributo admirável pela Verdade em si, são ao mesmo tempo um esforço necessário, de inteligência e bom senso, pela nossa verdade nacional. ${ }^{121}$

A conjugação entre a descoberta (ou o retorno) do que deveria ser essencialmente o país e a preocupação religiosa reaparece então constantemente, como é o caso da análise do livro de Paulo Prado, Retratos do Brasil, no qual Alceu enxerga o acerto em ver que nossa característica mais marcante como nação é a de possuir uma personalidade excessivamente romântica, desinteressada em preparar o futuro e de uma imprevidência sem rival ${ }^{122}$. Mas onde Prado enxerga um problema sem solução e, portanto, o futuro do país na sua dissolução em repúblicas menores, Alceu acredita que

${ }^{121}$ LIMA, Alceu Amoroso. Estudos. Rio de Janeiro, A Ordem, 1930 ( $3^{\text {a }}$ Série $-2^{\circ}$ Volume), p. 30-31.

${ }^{122}$ Sua apresentação da personalidade brasileira guarda em certa medida semelhança ao conceito de "homem cordial" tal como formulado por Sergio Buarque de Holanda na medida em que ambos consideram o brasileiro como avesso às coisas do intelecto e irracional em sua forma de administrar as relações sociais. 
a unidade nacional poderia ser mantida a partir da intervenção na cena pública da única instituição presente em todos os lugares e aspectos da vida brasileira desde sua fundação:

De modo que temos de corrigir pela estrutura exterior os perigos de dissolução a que nos levaria esse romantismo íntimo. E o remédio que vejo para resolver esse paradoxo, é - a volta à Igreja Católica.

A solução religiosa, a solução espiritual, aquela que respeita integralmente os direitos de nossa personalidade ao romantismo e os deveres de nossa nacionalidade ao realismo (LIMA, 1930, p. 186188).

Nesta passagem há uma mudança no próprio conceito de religião. Ela é de ora em diante identificada intrinsecamente com a instituição eclesial católica e dotada de uma plasticidade capaz de conformar de um lado o perfil da "alma" brasileira, em sua intimidade, e por outro, as agruras de construir um país. Alceu passa a considerar que os melhores leitores da realidade brasileira têm o perfil próximo ao de Sebastião Leme ou Leonel Franca. Ele deixa em segundo plano o intenso trabalho de reinterpretação do país feito pelos modernistas, sobre os quais já escrevera suas críticas ao longo da década.

Athayde travou novo embate com Sergio Buarque de Holanda poucos meses antes de ingressar no seio da Igreja, em artigo no qual lhe atribui a vontade de tomar o papel de líder do modernismo, privilégio que afirmou nunca ter desejado possuir ${ }^{123}$. Em meio a estes ataques pessoais, existe uma disputa sobre os critérios de autenticidade da arte. Sergio se ampara no surrealismo para dizer que a produção artística deve ser livre de todo empecilho - inclusive das consciências pessoais - e acusa seu oponente de trazer ideias nocivas para o desenvolvimento da arte ao invocar a necessidade de disciplina na produção artística. $O$ embate nacional se espelha naquele ocorrido na França, com Sergio evocando o nome de André Breton e Tristão, os de Julien Benda, Charles Maurras ou Jacques Maritain, unidos na visão de mundo católica, mas muito distintos em seus posicionamentos políticos.

O tom de Tristão se torna mais filosófico na medida em que a fé religiosa ascende em importância e atinge seu ápice no "Adeus à Disponibilidade", cujo título antecipa a resposta de Alceu à escolha entre as duas posturas que ele entende serem as

${ }^{123}$ LIMA, Alceu Amoroso. Construtivismo e destrutivismo. In: Estudos. Rio de Janeiro: Edição Terra de Sol, 1928 (1a Série), p. 191-200. 
possíveis para qualquer ser humano: 1) manter-se sempre na busca de um sistema filosófico capaz de explicar a totalidade da realidade ou, pelo contrário, 2) desistir da busca, tendo em vista a incapacidade de qualquer sistema filosófico de cobrir todas as dúvidas existenciais. $O$ tratamento endereçado a Sergio também se altera para uma tentativa de conciliação, de demonstrar que a busca é vã.

Tristão utiliza sua história pessoal de quem convivera com a dor e a angústia existenciais para lembrar a Sergio que a instabilidade onipresente no mundo também poderia se traduzir em problemas pessoais:

O necessário, porém, creio eu, é compreender que o mal é esperar por algum sistema. $\mathrm{O}$ erro é pensar que a realidade se prende em qualquer sistema humano apenas, ou em qualquer ausência sistemática de um sistema qualquer.

E V., que possui, no fundo, o verdadeiro sentido cristão da vida, precisaria apenas, creio eu, um pouco menos de desespero do homem, para alcançar também o senso católico que outra coisa não é senão a plenitude cristã. ${ }^{124}$

E a argumentação de Alceu prossegue no sentido de tentar provar como toda a filosofia moderna estaria amparada no equívoco de considerar o espírito humano como o centro de tudo o que existe, erro iniciado com o cogito de Descartes e perenizado por Kant. Na tentativa de fazer do próprio ser humano a garantia de resposta para as dúvidas existenciais e morais, a cultura ocidental estaria não apenas se afastando da religião mas criando situações desumanizadoras. Apenas ao aceitar sua incompletude e desaguar sua busca na religião é que a humanidade poderia devolver a dignidade ao ser humano.

"Adeus à Disponbilidade" foi adotado por Alceu como o marco inicial de sua conversão. Após haver percorrido o caudaloso conjunto de escritos no período, é possível enxergar que essa data, assumida simbolicamente por Alceu como sua volta à Igreja, poderia ser mais precisamente descrita como o final de um processo que durou alguns anos, a ser observado em seus momentos cruciais a partir das crônicas analisadas. Elas também permitem enxergar algumas das representações de Alceu em meio a este processo, isto é, fornece pistas de como ele enxergava sua trajetória de anunciador do movimento modernista rumo à defesa dos interesses de uma instituição tão tradicional como a Igreja.

${ }^{124}$ LIMA, Alceu Amoroso. "Adeus à disponibilidade" In: Adeus à disponibilidade e outros adeuses. Rio de Janeiro: Agir, 1969, p. 16-18. 
A conversão se torna inteligível quando examinada a partir do fascínio que a Igreja exerceu sobre Tristão antes de sua conversão, do qual outros escritores do período também foram alvo. A título de comparação, uma interessante análise biobibliográfica de Sergio Miceli em artigo sobre os primeiros livros dos modernistas de São Paulo ${ }^{125}$ revela que vários deles entabularam alguma relação com órgãos da Igreja, de onde retiravam alguma forma de apoio financeiro ou simbólico ou se utilizavam da temática religiosa na linguagem trabalhada pela obra. Menotti del Pichia, que havia estudado no Colégio Diocesano de Pouso Alegre - período no qual foi coroinha e publicou versos místicos - contou com a ajuda do bispo local para encontrar um emprego na cidade de São Paulo durante seu tempo de aluno do curso de Direito no Largo São Francisco ${ }^{126}$.

Outros, como Plínio Salgado (Thabor, 1919) e Mário de Andrade (Há uma gota de sangue em cada poema, 1917) utilizaram a linguagem religiosa para compor a estética de suas obras de estreia. Salgado encontra na religião católica o consolo para o sofrimento da morte de sua primeira esposa e transformou esta experiência em matéria para seu livro. Mário de Andrade possui um relacionamento ambíguo com a religiosidade católica, que Tristão notou diversas vezes. Em seu comentário a Paulicéia Desvairada, em 1922, Alceu ressalta a sinceridade do sentimento religioso de Mario, que não se enxerga nas missas frequentadas pela elite paulistana como se fossem mais uma atividade mundana, uma possibilidade de ver e de serem vistos pelos outros. Mas deixa implícita sua devoção em versos como no poema Domingo:

Mas Jesus Cristo no deserto... Santa Cecília regurgita de corpos lavados e de sacrilégios picturais...

Mas Jesus Cristo nos desertos,

Mas o sacerdote no "confiteor"... Contrastar!

-- Futilidade, civilização.

Em sua infância, Mário seguiu a tradição da família e foi um participante assíduo das organizações católicas voltadas para os leigos, além de membro da Congregação Mariana ${ }^{127}$. Se ao entrar na adolescência Mario abandonou qualquer

125 MICELI, Sergio. Experiência social e imaginário literário nos livros de estreia dos modernistas em São Paulo. Tempo social, São Paulo, v. 16, n. 1, jun. 2004.

${ }^{126}$ Oswald de Andrade, ex-aluno do Colégio São Bento, frequentava às escondidas as missas do mosteiro, em meio às atribulações de sua vida profissional e amorosa. Se por um lado isso não constitui nenhum vínculo com a instituição católica, vale como registro.

${ }^{127}$ A Congregação Mariana é uma criação dos jesuítas tão antiga quanto a colonização, mas que havia desaparecido com a expulsão dos jesuítas até ser restituída a partir de uma iniciativa em 
participação religiosa, traços dessa experiência permanecem em seus poemas por toda a vida e, no caso de seu primeiro livro (Há uma gota de sangue em cada poema), estão traduzidas em uma visão maniqueísta do panorama europeu da I Guerra Mundial, em um interessante paralelo com o tipo de escrita desenvolvido por Jackson de Figueiredo no mesmo período. Os pontos de contato entre estes autores residem na preocupação em reafirmar o compromisso com a verdade religiosa, identificando no objeto de análise: o "bem", associado aos valores cristãos e ao qual se deveria prestar todo o apoio possível, e o "mal" - a ser execrado e combatido com toda a força.

Desse modo, a leitura da situação política do mundo se torna uma leitura religiosa na qual França e Bélgica consistiriam no eixo do bem, a ser preservado, enquanto a Alemanha assume o papel oposto. Em Reação do Bom Senso, Jackson identifica o bernardismo - representante das tradições nacionais, do catolicismo e de seu inseparável espírito da ordem - à causa católica e associa Nilo Peçanha à maçonaria e aos inimigos da Igreja.

Os paralelos estabelecidos entre Jackson de Figueiredo e Mário de Andrade são exemplos da força que as ideias e as experiências da infância e mocidade percorrida em colégios e outras organizações católicas poderiam exercer sobre a geração de jovens da Primeira República ainda que seu ingresso na vida intelectual se desse em um ambiente hostil a intervenções de grande monta da Igreja. Este detalhe não passou despercebido no comentário de Sergio Buarque de Holanda em artigo publicado na revista Hierarquia. Em meio à discussão sobre a aprovação do ensino religioso nas escolas públicas, Sergio se questiona como foi possível que um sistema de ensino oficialmente laico houvesse produzido uma geração apaixonada pela defesa da religiosidade em todos os aspectos da vida.

A morte de Figueiredo por afogamento na baía do Guanabara, forçou uma solução talvez inesperada para todas as partes, mas que funcionou muito bem. Alceu foi escolhido por D. Leme como seu substituto no trabalho de arregimentação de novos fiéis, trabalho para o qual esteve legitimado tanto pela abertura dos primeiros anos de modernismo, quanto pelas posteriores demonstrações de apego à volta ao senso de ordem e equilíbrio, temas caros ao partido católico nas artes. Uma das razões para o sucesso de Alceu na liderança do laicato ao longo da década de 1930 foi sua sagacidade

Itu (SP) em 1870. Desde então constituiu um dos principais investimentos da Igreja para incutir aspectos do catolicismo devocional no público infanto-juvenil masculino, mas perdeu grande parte de seu prestígio com o aggiornamento da Igreja após o Concílio Vaticano II. 
em formar um corpo coerente de ideias que municiasse o exército de pretendentes ao posto de intelectual católico com suas estratégias de ocupação dos espaços sociais.

A geração de 1893, fundadora do Centro Dom Vital, elaborou um discurso de legitimação que se municiava da uma linha interpretativa da tradição católica brasileira eenfrentou a tarefa de construir para si uma tradição de nomes ao qual ela deveria dar continuidade na sua tarefa de produzir a "autêntica" cultura nacional. Com este objetivo eles produzem para si uma linhagem na qual eles próprios seriam os últimos herdeiros. O último elo da corrente seria Raimundo Farias Brito, um filósofo cearense nascido em 1864 em uma cidade desconhecida do interior do Ceará. Sua formação elementar se deu parte em Sobral e outra em Fortaleza, com interrupções de alguns anos por falta de condições de se manter no estudo. A família decidiu concentrar todo o esforço em Raimundo até ele se tornar Bacharel em Direito pela Faculdade do Recife.

Após concluir o curso, encontrou dificuldade de empregar-se tanto em Recife como em Fortaleza. Teve que contentar-se com a promotoria pública, exercida sem brilho em cidades do interior cearense. Por este motivo, mudou-se para o Rio de Janeiro em busca de melhores alternativas, mas teve de voltar logo para o Ceará por falta de opção de trabalho na capital.

Farias Brito fez parte de dois governos estaduais no Ceará, sendo o primeiro entre 1888 e maio de 1889, no governo de Caio Prado. Foi depois da destituição que ele resolveu ir para o Rio, segundo ele próprio desgostoso da política. Não conseguiu atrair atenção para seus livros e não obteve um emprego fixo. Decidiu se matricular na Escola Politécnica, com a justificativa de que tiraria daí mais material para completar seu sistema filosófico. A Proclamação da República alterou completamente seus planos e o fez voltar a ter pruridos de ingressar na política. Concorre a deputado federal na chapa de um político de oposição ao governo cearense e não consegue se eleger. Em acréscimo, precisa passar dias escondido da polícia, que por perseguição política invade sua casa.

A redenção parecia estar prestes a ocorrer durante o governo estadual do General Clarindo em 1892, quando foi chamado a fazer parte do secretariado do governo. O presidente da província era um ardoroso defensor de Floriano, e vê seu destino político comprometido com a deposição do presidente. Ele e todo o gabinete caem logo em seguinda. A experiência fracassada de 1892 é o turning point de sua trajetória, quando decide se dedicar exclusivamente à filosofia. Ainda no Ceará, publicou diversas obras: o 
$1^{\circ}$ Volume de a Filosofia como Atividade (1895), duas biografias no Instituto Histórico de Ceará: Tomás Pompeu (1896) e Guilherme Studart (1897) e, por fim, o $2^{\circ}$ Volume de A Filosofia como Atividade (1899). À parte esta produção bibliográfica, seus biógrafos $^{128}$ se mantem silenciosos sobre sua vida pública e privada, não havendo muitos dados sobre sua trajetória profissional. O pouco que se sabe é que depois destes fatos ele permaneceu até 1901 em Fortaleza, vivendo da advocacia e dos proventos de professor de História Geral no Liceu Cearense.

Ainda em 1901, fica consternado pela morte do pai e se casa uma segunda vez. Com a nova esposa ele se instala em Belém, onde atua inicialmente como Promotor Público, da qual renuncia para abrir sua banca de advocacia. Além disso, é professor da Faculdade de Direito de Belém, cidade em que publicou o terceiro volume de $A$ Finalidade do Mundo, além de A Verdade como Regra das Ações (ambos em 1905). Permanece na cidade até 1909, quando se estabelece definitivamente no Rio de Janeiro.

Neste ano de 1909, ele é aprovado em primeiro lugar no concurso para professor do Colégio Pedro II, mas o Governo Federal nomeia o segundo colocado: Euclides da Cunha. Quando este é assassinado pelo marido de sua amante, Farias Brito entra com requerimento para assumir a vaga. O parecer que recomenda sua contratação é de autoria de Silvio Romero. No Rio de Janeiro publicou A Base Física do Espírito (1912) e $O$ Mundo Interior (1914), livros que chamaram a atenção de Jackson de Figueiredo, com quem faz amizade. Sua tentativa de ingressar na Academia Brasileira de Letras, em 1916, é fracassada. Um texto chamado Panfleto, escrito em resposta à recusa da ABL e assinada com o pseudônimo de Marcos José, é sua última obra antes de falecer em 1917.

A herança de Farias Brito na história da filosofia brasileira pode ser discutida a partir dos livros de Cruz Costa e Antonio Paim ${ }^{129}$. Cruz Costa é bastante pessimista em relação à qualidade filosófica de Farias Brito, pois destaca a incapacidade deste autor de

\footnotetext{
${ }^{128}$ Entre os diversos perfis biográficos de Serrano, foram consultados três. O mais antigo entre eles é o de Jackson de Figueiredo, na "Introdução" de Algumas reflexões sobre a Filosofia de Farias Brito (1919). Vinte anos depois, Jônathas Serrano publica Farias Brito, o Homem e a obra, da qual Larte Ramos de Carvalho se aproveita em grande medida para seu perfil biográfico de Farias Bito, em se livro A Formação Filosófica de Farias Brito. Carvalho também se utiliza de outras fontes.

${ }^{129}$ COSTA, João Cruz. Contribuições à História das Ideias no Brasil. Rio de Janeiro: José Olympio, 1956.

PAIM, Antonio. O estudo do pensamento filosófico brasileiro. Rio de Janeiro: Tempo Brasileiro, 1979.
} 
desenvolver um sistema - mesmo que eclético - até suas últimas consequências. Considera sua linguagem confusa e enxerga em sua vontade de reunir em uma única obra todos os filósofos do Ocidente é um bovarismo intelectual característico da condição intelectual brasileira. No caso da produção filosófica, existe a dificuldade sobressalente de se manter em contato com outros países, especialmente os centros de referência. Por este motivo, não havia tantos autores a partir dos quais fosse possível construir sua referência e qualquer livro europeu que chegasse ao Brasil poderia ser considerado uma joia rara.

Apesar das restrições apresentadas, Farias Brito teve uma repercussão consideravelmente grande: foi lido pelos integralistas como um pioneiro e uma referência no "descobrimento" da identidade brasileira. Segundo Cruz Costa, isto seria possível porque apesar de ter anunciado publicamente sua renúncia a tratar de política, Farias Brito sempre quis fazer de sua obra um guia para a reforma social, o que não deixa de ser uma intervenção na cena política a fim de determinar os termos nos quais se darão o debate. Além disso, é justamente seu caráter difuso e o fato de repisar a necessidade de uma regeneração o que pode ser aproveitado de sua obra com a finalidade política que se desejar, mas especialmente em movimentos como o integralismo, desejoso de fazer crer que a política devesse ser substituída pela moral.

Por outro lado, Antonio Paim lamenta o fato de poucos compreenderem como ele foi essencial para o pensamento católico, sendo o responsável pela conversão de toda a geração de 1893.

A amizade com Farias Brito foi significativa para Jackson de Figueiredo e resultou em dois livros a seu respeito. O primeiro foi mais abrangente e se chama Algumas reflexões sobre a filosofia de Farias Brito (1916). Publicado três anos depois, A Questão social em Farias Brito (1919) dedica-se a um tema mais específico. Algumas reflexões... reúne cinco ensaios escritos em períodos distintos, segundo ele próprio esclarece na introdução do livro, com os três primeiros concluídos antes de sua conversão ao catolicismo. A decisão é justificada pela iniciativa de deixar ao leitor a oportunidade de conhecer a transição em seu pensamento, do apego ao positivismo patente no primeiro artigo $^{130}$ à entrega total ao catolicismo do último.

${ }^{130}$ FIGUEIREDO, Jackson. Uma teoria do conhecimento. In: Algumas reflexões sobre a filosofia de Farias Brito. Rio de Janeiro: Revista dos Tribunais, 1916, p. 15-60. 
Além das obras de cunho filosófico, Figueiredo enveredou pela crítica literária. Em seus escritos, a defesa do ponto de vista católico se dá por meio da ideia de que toda obra de arte possui em si um conceito de moral e de ordem. E que, portanto, não era indiferente aos problemas concernentes a estas duas esferas. Como a neutralidade é impossível no que se refere à moral - pois toda ação humana tem efeito sobre os outros - logo se deve aplicar também à obra de arte o raciocínio de saber se ela é condenável ou moralmente boa. E é assim que o julgamento religioso sobre a arte é tão importante quanto o estético. Tendo estabelecido esta condição prévia, Figueiredo passa a embrenhar-se na floresta de tradições literárias europeias para retirar delas bons exemplos de como deveria ser o tipo de obra e de crítica a ser produzida no Brasil.

Mesmo antes de sua conversão, o tipo de crítica que Jackson pretendeu fazer era completamente distinto do realizado por Alceu, investindo em autores como Garcia Rosa, Auta de Souza e Xavier Marques. Destes dois últimos, é possível dizer que há alguns traços em comuns, como a ligação com famílias de representatividade política regional. Xavier Marques começou a exercer seu primeiro mandato como deputado estadual no mesmo ano em que Jackson de Figueiredo publicou o ensaio de crítica a seu respeito; Auta de Souza tinha dois irmãos que se consagraram na política por estados diferentes. Elói de Souza foi deputado estadual, federal e senador, todos os mandatos por Pernambuco. O início de sua vida política se deu em 1914. Seu irmão mais velho, Henrique Castriciano de Souza, foi vice-governador do Estado e presidente do Congresso Legislativo do Estado. Ambos eram políticos bem estabelecidos quando o livro sobre Auta de Souza foi publicado em 1924.

Ao escrever sobre tais poetas, Figueiredo não poderia deixar de ter em mente as diversas formas de dividendos derivadas de sua escolha. Além de estabelecer alianças implícitas com representantes das elites regionais, suas críticas poderiam garantir a ele uma posição estratégica de introdutor de novos talentos nordestinos no Rio de Janeiro. As escolhas de Figueiredo representaram os momentos distintos de sua trajetória intelectual.

A construção de uma nova crítica literária vai além do âmbito nacional e busca em exemplos da literatura portuguesa e francesa modelos (a imitar e a evitar) do que deveria ser a literatura nacional. Fialho de Almeida merece apenas críticas, pois seu estilo era de um materialismo nocivo à boa literatura; sobre Antonio Sardinha, Figueiredo analisou apenas sua produção poética, elogiada em sua capacidade de unir a 
evocação do passado com a do catolicismo, pois ambos faziam parte da alma portuguesa. Entre os autores franceses, são mobilizados Henri Massis na crítica de arte e Bureau na produção de um saber sociológico. Do primeiro, Figueiredo menciona a ideia de que o homem é uma atividade moral, e todo o produto de sua atividade - inclusive a arte - precisa ser apreciado a partir da educação moral que pode gerar. O segundo cria uma divisão sui generis entre a ciência social, que como toda ciência, é amoral, e a sua aplicabilidade prática - a arte social. Esta também pode ser apreciada em termos do que é bom e do que é ruim, como qualquer outra ação humana ${ }^{131}$.

A visão que Jackson de Figueiredo apresenta sobre a literatura está ligada à crítica a todo tipo de arte de vanguarda que ele encontra no Brasil e no exterior, diferentemente de Tristão, imerso nos círculos literários e artísticos. Por este motivo, sua substituição por Amoroso Lima representou uma alteração no modo como a revista enxergava a literatura e na possibilidade de literatos que cultivavam gêneros de vanguarda habitarem o Centro. Conforme observou Marcelo Tadeu Schincariol ${ }^{132}$, a quantidade de nomes da vanguarda literária carioca que frequentam o Centro poderia suscitar um questionamento a respeito da aparente falta de sintonia entre as posturas esteticamente conservadoras previamente adotadas por A Ordem e a produção destes autores.

As obras de crítica literária de Jackson e Tristão formam um corpo de escritos complementado pelo esforço em ditar as regras de desenvolvimento em outros campos de conhecimento, notadamente a História, a Filosofia e a Sociologia. O próximo capítulo tratará desta outra parte das obras dos vitalistas e completará o quando de seu pensamento sobre a cultura brasileira .

${ }^{131}$ Embora Amoroso Lima não mencione Bureau, parte da discussão presente em seu livro Preparação à Sociologia se dá em termos análogos aos propostos por ele.

132 SCHINCARIOL, Marcelo Tadeu. A arte complexa de ser infeliz: a ficção de Cornélio Penna. Campinas: UNICAMP, 2009. 385f. Tese (Doutorado em Teoria e História Litetária) Instituto de Estudos da Linguagen-IEL, Unicamp, Campinas, 2009. 
Capítulo IV: Ensino religioso, educação e as relações entre ciência e fé 
Na década de 1920, vários intelectuais e políticos se esmeraram por diagnosticar as razões do estado calamitoso da formação escolar da maioria dos brasileiros. O protagonismo da educação na consolidação do país fora objeto de reflexão no decênio anterior, quando as ligas nacionalistas e outras associações passaram a identificar os índices de analfabetismo e a baixa formação escolar como os grandes problemas do país. Por este motivo, a década de 1920 representou uma inflexão significativa na história da educação do Brasil, pois dele resultou a formação da pedagogia como um campo do conhecimento específico e autônomo em relação aos outros.

Pela primeira vez na História do Brasil, carreiras profissionais foram construídas a partir do enfrentamento das questões concernentes aos sistemas públicos de ensino, na preocupação de reforma-los. Embora a questão da educação estivesse de alguma forma associada à crise do sistema oligárquico, a formação da pedagogia como um ramo autônomo é ao mesmo tempo causa e consequência da ideia de que os problemas da educação deveriam ser enfrentados a partir de métodos próprios com o emprego de técnicas legitimadas pela produção científica contemporânea e não por alguma autoridade religiosa ou política.

Esta nova disciplina, da qual resultou simultaneamente uma forma de produzir ciência e uma intervenção direta na administração pública, era propalada por uma série de jovens intelectuais, como Lourenço Filho, Anísio Teixeira e Fernando de Azevedo. As reformas nos sistemas de ensino estaduais, promovidas por eles, especialmente na sua parte concernente ao ensino primário, possuíam o ensejo de ampliar a quantidade de alunos atendidos. Embora as redes de ensino secundário e universitário não tenham sofrido grandes mudanças durante as reformas dos anos 1920, elas seriam consideravelmente afetadas nas décadas seguintes, resultando nas criações da Universidade do Distrito Federal e da de São Paulo.

As mudanças eram vistas com grande desconfiança por boa parte dos vitalistas, a começar por Jackson de Figueiredo ${ }^{133}$. A ênfase conferida ao ensino profissionalizante enfraquecia o uso da noção jesuítica de um currículo baseado na cultura clássica; a preocupação com a formação moral na escola cedia espaço para a formação científica. A finalidade proposta para a educação se alterava radicalmente, de um modo

\footnotetext{
${ }^{133}$ Nagle menciona como elementos a corroborar a tese da falta de empenho dos católicos ao tema das reformas de ensino a ausência quase completa do assunto nas páginas d'A Ordem durante a fase na qual ela esteve sob a direção de Jackson de Figueiredo, ou ainda os "12 Marcos Gil Blas", texto publicado na revista de mesmo nome do manifesto.
} 
desfavorável à Igreja. Em acréscimo, havia um componente de disputa política do apoio das famílias oligárquicas, posto que as mesmas elites estaduais que se compraziam em financiar a ampliação dos seminários antigos ou a construção de novos, e assim reforçar a rede católica de ensino, decidiram apoiar as medidas educacionais que colocavam em risco esta concepção de educação.

Os antecedentes do movimento pela reforma da educação da década de 1920 indicavam os riscos para os interesses da Igreja. Durante os primeiros momentos da República, os prognósticos apontavam a educação como prioridade, mas poucas reformas dotadas deste espírito republicano saíram do papel. Uma exceção foi a reforma empreendida por Caetano de Campos no estado de São Paulo em 1892. Ela se serviu de diversos profissionais da escola presbiteriana da capital, a joia da coroa de um sistema de colégios protestantes que resistiu às agruras do Império e sua união oficial com a Igreja Católica.

As diversas denominações protestantes fundaram cerca de uma dezena de colégios no Brasil, calcados em uma pedagogia crítica ao método jesuíta, cuja ênfase não estivesse na repetição de uma cultura clássica, mas no desenvolvimento das habilidades práticas necessárias para a vida adulta. Os primeiros colégios foram criados ainda durante o Império -- São Paulo (1870) e Rio (1868) - mas o início da República consagrou a fórmula do Estado laico e, dessa forma, novas instituições surgiram em diversas cidades, como as de Salvador, Curitiba (1892), Florianópolis (1903), Campinas e Aracaju (1900). Neste último estudou Jackson de Figueiredo, desde sua fundação até seu fechamento, em $190{ }^{134}$. A afinidade entre os ideais republicanos e a pedagogia destes colégios foi notada por algumas autoridades religiosas, como foi o caso de A. R. Cabtree:

O Evangelho encerra os princípios de democracia, individualismo, igualdade de direitos, liberdade intelectual e religiosa. A democracia política não pode florescer entre um povo sem instrução. O êxito do

${ }^{134}$ SILVA, Olegário. Infância e Adolescência. In: A ORDEM. Rio de Janeiro: Centro Dom Vital, ano VIII, n. especial, mar. 1929.

VILAS-BÔAS, Ester. Origens da educação protestante em Sergipe (1884-1913). In: CONGRESSO BRASILEIRO DE HISTÓRIA DA EDUCAÇÃO, 1., 2000, Rio de Janeiro. Anais eletrônicos...Rio de Janeiro: UFRJ, 2000. Disponível em: $\langle$ http://www.sbhe.org.br/novo/congressos/cbhe1/anais/051_ester_fraga.pdf $>$. Acesso em: jan. 2013. 
individualismo evangélico depende da educação do povo, especialmente no ambiente em que predomina o catolicismo. ${ }^{135}$

$\mathrm{Na}$ visão expressa acima, compartilhada por muitos outros reverendos, o "individualismo evangélico" se traduzia em termos políticos pela representação liberal da sociedade como a soma dos indivíduos. A tentativa de alavancar a educação evangélica ao projeto republicano recebeu, no entanto, pouco incentivo da classe política dirigente, exceção feita aos membros do Partido Republicano Paulista que se aproximaram das iniciativas de educação presbiteriana. Por exemplo, a criação de uma instituição escolar dessa denominação em Campinas recebeu o apoio de diversos deles $^{136}$. Na maioria dos casos, entretanto, os colégios funcionavam em condições precárias, nas dependências da Igreja presbiteriana local e tinham de enfrentar a concorrência de seus pares católicos, o que levou muitos deles a não durarem muito tempo, como foi o caso em Aracaju.

Os colégios protestantes e públicos alimentaram o receio da Igreja de perder espaço na formação das novas gerações de jovens. Por este motivo, a hierarquia abriu espaço para que os representantes leigos atuassem neste campo. Assim como a crítica literária correspondia a um projeto político de intervenção na cena pública através da cultura, os temas ligados à educação também punham em disputa visões conflitantes de como deveria se dar o desenvolvimento do país e quais deveriam ser os grupos a ditar as regras do tipo de educação a ser fornecido.

Um exemplo das implicações políticas dos planos de educação é a aliança estabelecida entre os escolanovistas e os políticos mais radicais do grupo liderado por Vargas. Quando Pedro Ernesto assumiu a Intendência do Rio de Janeiro, vários pioneiros da educação foram empregados na Secretaria de Educação e eles atuaram com seu total apoio. A Igreja perdia espaço até na sua diocese mais importante do período.

Os diversos interesses da Igreja também estavam traduzidos nas obras de Tristão de Athayde, após sua conversão, debatidos nesta tese na ordem pela qual são publicados. A primeira é Debates Pedagógicos, livro publicado pela Schmidt Editora

${ }^{135}$ CABTREE, A. R. História dos Batistas. Rio: Casa Publicadora Batista, 1962, v. 1, p. 125 , apud. HACK, Osvaldo Henrique. Protestantismo e educação brasileira. São Paulo: Editora Cultura Cristã, 2000, p. 77.

${ }^{136}$ Francisco Quirino dos Santos, Joaquim Egídio de Souza Aranha, Campos Salles, Francisco Glicério e Rangel Pestana. Este último também viria a se tornar professor do Mackenzie, em São Paulo. 
em 1931 com um acabamento simples e sem novas edições até a coleção completa das obras de Alceu, em 1947. Trata-se de uma coletânea de textos escritos para ocasiões distintas, alguns já posteriores à aprovação do Ensino Religioso nas escolas públicas realizada através do decreto de 19.941, de 30 de Abril de 1931. É significativo que sua data de promulgação suceda em poucos meses o decreto número 19770, de 19 de março de 1931, proibindo a propaganda religiosa nos sindicatos. Em seu conjunto, eles delinearam os pilares do relacionamento entre a Igreja e o Estado, os quais não foram modificados durante todo o regime varguista: à Igreja caberia o papel de cuidar da formação das almas para garantir a obediência ao regime, mas o sindicalismo constituiria um monopólio estatal.

No momento em que os dois decretos são assinados, ainda não estava claro se o Governo Provisório poderia ser considerado um aliado confiável. Em artigo publicado logo depois de aprovar o ensino religioso, Amoroso Lima comemora a novidade com a ressalva de que este seria apenas o primeiro passo de uma revolução espiritual, a única digna deste nome e capaz de salvar o país ${ }^{137}$. Este artigo permitia enxergar um Tristão relativamente autônomo frente à recomendação de D. Leme para que todas as instituições da Arquidiocese mantivessem uma postura de neutralidade em relação ao novo regime. Para Alceu, a revolução espiritual necessária para o país seria aquela em que os valores da América protestante, que dominou o século XIX, fossem substituídos pela tradição católica reinventada. O protestantismo ainda era visto como o principal inimigo do Brasil pelo texto, ao contrário do comunismo, do qual não se tem grande receio ainda. Em Debates Pedagógicos, a educação é vista como um problema de formação de uma elite nacional. Por este motivo, o ensino universitário também é bastante debatido.

Naquele início da década de 1930, o que estava em disputa era o tipo de ensino universitário a ser privilegiado: humanístico ou empírico? Privilegiando a filosofia (ou a teologia) ou as ciências "duras”? A este respeito, o interlocutor é Azevedo Amaral, que propõe uma divisão positivista das ciências na organização dos cursos universitários. Alceu identifica no Ministro da Educação, Francisco Campos, uma tentativa de agradar ambas as correntes, criando uma divisão dos currículos inspirada no positivismo de Azevedo Amaral, mas com o acréscimo da teologia e da metafísica como um

${ }^{137}$ LIMA, Alceu Amoroso. Debates Pedagógicos. Estudos de Filosofia da Educação. Rio de Janeiro: Schmidt Editora, 1931, p. 1. 
complemento da atividade universitária. A rejeição dessa alternativa conciliatória é justificada por Alceu a partir da prerrogativa de que a teologia deveria ser o centro da vida universitária.

O tema do ensino religioso também é relevante para detectar o grupo daqueles que não desejavam que a Igreja lograsse seu intento de marcar a vida pública dos futuros cidadãos desde seu início. Por exemplo, no início de 1931, a aprovação do ensino religioso nas escolas laicas era bastante criticada pelo Diário de Notícias $^{138}$. O ministro Francisco Campos foi descrito nas páginas deste jornal como um político incoerente, que ora defende uma concepção liberal de educação e outras vezes, uma visão católica. Um ano depois, o tema do ensino também movimenta os redatores de artigos de opinião, entre eles Carlos Lacerda ${ }^{139}$ e um pseudônimo auto-intitulado "João Pátria”, a favor dos católicos. Ambos trocam diversos artigos a respeito da educação.

Lacerda insiste na denúncia da omissão de gente como Fernando Magalhães, que deveria zelar pela imagem do ensino público, mas prefere participar das cerimônias promovidas pelo Centro D. Vital, nas quais este ensino é menosprezado. Declara, ainda,

${ }^{138}$ O Diário de Notícias surgiu em 12 de junho de 1930 pelas mãos de Orlando Ribeiro Dantas, Nóbrega da Cunha e Figueiredo Pimentel, jornalistas egressos de $O$ Jornal. Imerso na crise que se seguiu à eleição de Júlio Prestes, tomou uma postura de apoio à Aliança Liberal, mais especialmente aos tenentistas. $\mathrm{O}$ apoio foi mitigado à medida que Vargas assume a centralidade da cena política, prolongando sua estadia após a eleição de 1934. A Revolução de 1932 recebeu amplo apoio e a nova Constituição foi saudada como uma vitória, pelo que representou em termos de limitação de poder de Vargas. Logo o jornal passaria e acumularia dissabores. Após decidir-se pelo apoio a Borges de Medeiros na eleição presidencial ainda em 1934, o jornal saiu derrotado. Também foi contra a polarização entre AIB e ANL na cena política nacional, na contramão dos discursos dos dois movimentos. Sua terceira derrota apareceu na eleição de 1938, quando o jornal posicionou-se em favor de Armando Sales de Oliveira e contra o candidato da situação José Américo de Almeida. A respeito do ensino religioso, conferir as seguintes notícias:

REZENDE, Garcia de. Entre Deus e o Diabo, Diário de Notícias, Rio de Janeiro, p. 3, 21 abr. 1931.

PESSÔA, Frota. A reforma da instrução e o ensino religioso. Diário de Notícias, Rio de Janeiro, 08 maio 1931, Página de Educação, p. 7.

PESSÔA, Frota. A apostasia de um leader, Diário de Notícias, Rio de Janeiro, 29 maio 1931, Página de Educação, p. 7.

JULIANO, Claudio. Religião por decreto, Diário de Notícias, Rio de Janeiro, 04 jun. 1931, p. 6.

${ }^{139}$ Então um estudante da Faculdade de Direito do Rio de Janeiro, cuja família paterna possuía vários membros (inclusive seu pai) no partido comunista. Mas ele próprio só se aproximaria da Juventude Comunista em 1934, sem nunca ter feito parte dela oficialmente. 
em uma de suas respostas, saber que por detrás do pseudônimo de João Pátria escondese um diretor de um estabelecimento privado, com interesses pessoais pelo mau funcionamento das escolas públicas, suas concorrentes ${ }^{140}$. Rebate o uso constante que João Pátria faz das ideias de Tristão de Athayde, definido como "um antigo confusionista que não conhece o comunismo e tem por hábito citar, de quando em quando, alguns autores clandestinos para combater ou defender certas doutrinas extremadas".

Nessa última declaração, Carlos Lacerda faz menção a um aspecto primordial ao pôr em cheque a legitimidade de Amoroso Lima em agir como o chefe de fila do grupo dos católicos, buscando retirar dele toda legitimidade de indicar quais são os bons e os maus autores. Sua tentativa não é acompanhada de outros artigos de teor semelhante; pelo contrário, alguns meses após os ataques, Alceu é convidado a participar do dossiê do jornal em resposta à questão "haverá uma crise de espírito no mundo moderno?"141.

Sua resposta caminha no sentido de saber qual será essa crise, suas causas e sintomas. Para Alceu, a resposta a todas essas perguntas passa pela quebra de hierarquia entre o que é mais importante e o que é secundário na vida social. Em sua opinião, seria uma invenção absurda considerar que a religião devesse ficar abaixo da ciência, ou a moral abaixo da instrução no papel que a escola deveria desempenhar. Em suma, Alceu reproduz nas linhas deste jornal o mesmo raciocínio que aplicara nas páginas escritas para "O Jornal”, reforçando sua linha de atuação com o acréscimo de outro veículo da grande imprensa.

${ }^{140}$ PATRIA, João. Ensaia-se o comunismo no ensino, Diário de Notícias, Rio de Janeiro, 19 abr. 1932. A pedidos, p. 4.

LACERDA, Carlos. Muito grave e muito comprometedor, Diário de Notícias, Rio de Janeiro, 25 maio 1932. Página de Educação.

LACERDA, Carlos. Phases e phrases do Sr. Reitor, Diário de Notícias, Rio de Janeiro, 27 maio de 1932. Página de educação, p. 6.

PATRIA, João. Prossegue impávida a orientação bolshevista do ensino municipal, Diário de Notícias, Rio de Janeiro, 28 jun. 1932. A pedidos, p. 4.

LACERDA, Carlos. Contra a má fé dos interessados, Diário de Notícias, Rio de Janeiro, 29 jun. 1932. Página de Educação, p. 6.

141 LIMA, Alceu Amoroso. Haverá uma crise de espírito no mundo moderno?, Diário de Notícias, Rio de Janeiro, 14 jun. 1932. 
Outro periódico com manifestações a respeito do tema é Hierarquia, de propriedade de Lourival Fontes, um conterrâneo de Figueiredo que o reencontrou no Rio de Janeiro e através dele passou a frequentar o Centro Dom Vital. Possuía um círculo de amizades bastante heterogêneo, do qual faziam parte diversos nomes de críticos à democracia liberal em crise, entre os quais o médico Pedro Ernesto, com quem rompeu relações quando este governou a capital federal. O motivo do desentendimento foi o apoio do prefeito ao projeto de reforma da educação proposto por Anísio Teixeira, o qual tornava mais difícil o ensino religioso nas escolas.

O primeiro número de Hierarquia revela uma linha editorial que mistura elementos de diversas correntes políticas e culturais. O nome da revista indicava uma referência clara a Mussolini e ao regime fascista, o qual publicava uma revista homônima; na revista marcavam presença visões autoritárias (Oliveira Vianna, Octavio de Faria, Azevedo Amaral) integralistas (Santiago Dantas - frequentador da AUC e Plínio Salgado) e de vitalistas (Sobral Pinto e Amoroso Lima). Nos anos seguintes à fundação da revista, Fontes decide acompanhar a consolidação de Vargas como o chefe máximo do regime e toma a defesa do regime como seu principal objetivo. A fidelidade seria bem recompensada com o cargo de direção do Departamento de Imprensa e Propaganda ${ }^{142}$.

A abordagem eclética do primeiro número fica patente pelo artigo de Sergio Buarque de Holanda, que contraria a linha da maioria dos artigos da revista (mas não todos) de se mostrarem favoráveis ao ensino religioso. Ele repudia qualquer tentativa de conciliar um Estado que insiste em sua profissão de fé liberal com uma Igreja cuja condenação ao liberalismo era irredutível e centenária. Para este autor, a inconsequência não era menor entre os católicos, mesmo os portadores de uma visão social antiliberal, "particularmente quando se fazem sociólogos e economistas, quando chegam a propor

${ }^{142}$ Estes dados foram colhidos do artigo:

OLIVEIRA, Lúcia Lippi. "O intelectual do DIP: Lourival Fontes e o Estado Novo" In:

Constelação Capanema: intelectuais e políticas. Rio de Janeiro: FGV, 2001

A análise da autora sobre Lourival Fontes se estende até o final do Estado Novo, período no qual sofreu dois revezes importantes. A entrada do Brasil na Segunda Guerra implica na sua saída do DIP, posto que ele era um nome muito próximo do fascismo. Rebaixado para cargos mais discretos no Palácio do Catete, é considerado como um traidor próximo do final do Estado Novo e rejeitado por Vargas. 
formas de organização e tentativas de itinerário, com programas de ação social e nacional" $" 143$.

A expressão Tentativa de Itinerário não é fortuita: ela era o nome de um texto publicado por Amoroso Lima em 1929, pouco depois de sua conversão, na continuidade da problemática de explicação da conversão apresentada em "Adeus à disponibilidade". Esta mudança radical de vida era apresentada à juventude de 1929, que nas palavras do próprio Tristão era diferente da sua geração -- pois não perdera o otimismo de encontrar respostas para as grandes questões existenciais, como se algo assim fosse impossível ${ }^{144}$.

Sergio considerava que Tristão combatia o Estado Autoritário sob falsos pressupostos. Este não seria formado com base na perseguição à religião, mas no suporte material à sua prática, de modo a transformá-la em alicerce do novo regime. A resposta é apresentada no mesmo dossiê por Leonel Franca ${ }^{145}$ e começa por afirmar que o debate intelectual sobre a lei do ensino religioso já estava vencido pelas forças católicas. Franca apresenta casos de aprovação do Ensino Religioso em outros países europeus para concluir que a adoção da medida era consensual mesmo nas regiões onde o catolicismo convivia com outras crenças. Franca repete sua estratégia de enumerar todos os argumentos em favor de sua visão à exaustão e não admitir nuances ou matizes.

Outro jornal que se evolveu na disputa em torno do ensino religioso foi o Díário de Notícias, no qual Oswald de Andrade é um dos colaboradores. Sua participação no jornal visa o ataque a Alceu, desferido em tom de galhofa e ironia ácida, através de alegorias tais como "o grande Industrial, das asas gandhistas com que queria amortalhar a humanidade falecida de fome" 146 ou afirmando que ele é como "um quarto abafado que provoca mal estar nos próprios católicos, pois não se envergonha de falar em anjos num tratado de sociologia que pretende ser sério". ${ }^{147}$ As comparações reforçam a ideia de um intelectual de tripla personalidade, todas tidas como conflituosas entre si: o industrial que possui um exército de operários sob seu comando, o crítico

${ }^{143}$ HOLANDA, Sergio Buarque de. O Ensino Religioso em face do livre pensamento, Hierarchia, Rio de Janeiro, ano 1, v. 1, p. 3-5, ago. 1931.

${ }^{144}$ AMOROSO LIMA, Alceu. "Tentativa de itinerário" EM: _.. Adeus à disponibilidade e outros adeuses. Rio de Janeiro: Livraria Agir Editora, 1969, pp. $\overline{16-30 .}$

${ }^{145}$ FRANCA, Leonel. Aspecto Social e Pedagógico do Ensino Religioso, Hierarquia,Rio de Janeiro, p. 8, ago. 1931.

${ }^{146}$ Diário de Notícias, 08 jun.1933.

${ }^{147}$ Diário de Notícias, 28 maio 1933. 
literário/sociólogo cujas ideias são científicas e antenadas com os problemas sociais e, por fim, o apologeta da fé. O resultado disso seria um sociólogo que não se pode levar a sério e um doutrinador social que defende os interesses de seu lado industrial, confirmando seu julgamento sobre a Igreja, associada com a defesa dos privilégios deste mundo.

Apesar da veemência no discurso de Oswald, suas críticas tampouco receberam eco. O nome de Tristão é citado por outros artigos, como o de Silva Bruno ${ }^{148}$, que enxerga no sociólogo católico o produtor da forma mais avançada de sociologia daquele momento. Rodrigo Melo Franco de Andrade $^{149}$ também emplaca um artigo altamente simpático a seu amigo, acrescentando acenos a outros vitalistas de gerações mais novas de escritores, como Octavio de Faria, Mucio Leão, Agrippino Grieco e Lúcia Miguel Pereira. Em 1935, Amoroso Lima é eleito para a Academia Brasileira de Letras e o Diário de Notícias saúda a escolha como altamente positiva, chegando a afirmar que esse fato redime a Academia de erros anteriores. Nos anos posteriores, um comentário otimista reaparece quando este autor publica novas obras como Idade, Sexo e Tempo. O livro é descrito como uma brilhante defesa de Alceu do direito de manter sua personalidade e mudar de ideia quando julgasse tal necessário. A resenha não deixa claro que tipo de mudança seria essa. Apenas informa que embora o livro não tivesse caráter declaradamente autobiográfico, Alceu expressaria nele as experiências de toda a sua geração ${ }^{150}$.

148 BRUNO, Silva. A sociologia confederacionista. Diário de Notícias, Rio de Janeiro, 03 fev. 1934, Primeira Secção, p. 2.

É provável, embora não seja possível assegurar, que o autor seja Ernani Silva Bruno, nascido em Curitiba em 1912 e formado em Direito na Faculdade de São Paulo. Ele trabalhou na imprensa e chegou a coordenar o suplemento literário de A Noite. Sua obra mais conhecida é História e Tradições da Cidade de São Paulo (1953), em três volumes.

${ }^{149}$ Nascido em Belo Horizonte, em 1898, a vida de seu tio foi o objeto do primeiro livro de Alceu Amoroso Lima.

${ }^{150}$ A resenha citada é de Rosario Fusco, "Depoimento de uma geração", Diário de Notícias, 19/06/1938, p. 2. Outros artigos citados:

O NOVO membro da Academia de Letras, Diário de Notícias, 01/09/1935, p.5.

SAMPAIO, Newton. Mestre Eloy, Diário de Notícias, Rio de Janeiro, p. 3, 12 set. 1937.

LINS, Álvaro. Defesa do crítico católico, Diário de Notícias, Rio de Janeiro, 11 fev. 1940. Primeira Seção, Letras, artes, ideas geraes, p. 8. 
O assunto do ensino religioso também ocupou as páginas de outros periódicos no mesmo período. O Diário Carioca ${ }^{151}$, por exemplo, é marcado pela crítica do ponto de vista liberal - perceptível no momento da aprovação da lei do ensino religioso, em $1931^{152}$, quando o jornal reproduziu opiniões dos próprios católicos contrários à medida. Para o jornal, o ensino religioso traria a confusão na organização do ensino, pois seria impossível administrar o direito de todas as religiões a se fazerem representar no currículo escolar. Nesse quadro, era previsível que o catolicismo fosse favorecido como a única religião a ter sua doutrina ensinada em escolas laicas, borrando a saudável (na opinião do jornal) fronteira entre a Igreja e o Estado. Acrescente-se a isso que o clero não deveria solicitar o auxílio do poder secular a uma função que deveria ser exclusivamente sua.

Os embates nos quais se envolveram os membros do Centro combinaram uma série de temas ligados à educação, desde o ensino primário até o currículo das faculdades a serem criadas. Ao interesse pelo ensino religioso na formação inicial dos indivíduos correspondia uma disputa em torno do modelo de ensino universitário que o país deveria adotar, o que implicou também em impedir o surgimento de universidades autônomas em relação ao Ministério da Educação. A Universidade do Distrito Federal, realização do prefeito Pedro Ernesto e sua secretaria de educação, foi uma resposta à aliança gerada pelos interesses partilhados entre os vitalistas e o titular do Ministério, Gustavo Capanema. Esta aliança foi reiterada por diversos estudiosos do período, entre os quais Sergio Miceli, que a definiu nos seguintes termos:

[Capanema] firmou sua carreira política em função das alianças com os principais grupos de interesse no campo do ensino e da cultura,

\footnotetext{
${ }^{151}$ O Diário Carioca foi fundado por Macedo Soares em 1928 e durante seus dois primeiros anos fez oposição ao governo de Washington Luís, apoiando abertamente a Aliança Liberal inclusive durante o processo de tomada do poder através das armas. Entretanto, a proximidade inicial do regime com a corrente tenentista desagradou Macedo Soares, que transformou o jornal em um instrumento de oposição ao Governo Provisório. Embora tivesse se oposto ao último regime da Primeira República, a linha política escolhida para o Diário Carioca confirmava sua defesa intransigente de uma volta ao equilíbrio político anterior a Outubro de 1930, com o fim das experiências de inovação promovidas pelos tenentistas. Com a volta da Constituição em 1934, essa meta foi alcançado e assim o jornal se aproxima do regime, a ponto de saudar no ano seguinte a Lei de Segurança Nacional como benéfica aos interesses do país -- em claro contraste com a postura anterior de defesa intransigente da liberdade de expressão.

152 "O ensino religioso nas escolas". Diário Carioca, 06/05/1931, p. 10. Ainda surfando na onda deste anticlericalismo Mario Pinto Serva escreve "O Salvador Místico" (Diário Carioca, 29/05/1931, p. 2) no qual afirma que os países católicos são aqueles nos quais as ditaduras vicejam com maior facilidade e as populações são as mais analfabetas.
} 
particularmente a Igreja Católica e seus porta-vozes leigos (Alceu Amoroso Lima, Jônatas Serrano, Hamilton Nogueira etc.) e eclesiásticos (pe. Leonel Franca, por exemplo), bem como dos espaços conquistados pelos sucessivos empreendimentos que favoreciam a incorporação de artistas e intelectuais cobrindo praticamente todos os matizes do espectro ideológico. (MICELI, 2001, p. 116-117)

A aliança referida por Sergio Miceli deu-se desde o início do ministério Capanema, em 1934, e não pode ser compreendida sem avaliar a condenação que recebeu dos jornais da época. O mais incisivo foi A Manhãa, cujas páginas acolheram artigos de praticamente todos os nomes mais relevantes da Aliança Nacional Libertadora. O jornal foi lançado em 26 de abril de 1935 por Pedro Mota Lima e empastelado sete meses depois, na onda repressora do governo federal em resposta ao movimento militar de outubro de 1935. Pagou um alto preço por sua ligação intrínseca com a Aliança Nacional Libertadora, mas abrigou em sua curta vida contribuições de gente de peso na vida cultural brasileira, tais como Di Cavalcanti ${ }^{153}$, Hermes Lima ${ }^{154}$, Jorge Amado ${ }^{155}$, Maurício de Lacerda ${ }^{156}$, Anísio Teixeira ${ }^{157}$, Rubem Braga ${ }^{158}$ ou Josué

${ }^{153}$ Pintor nascido no Rio de Janeiro em 6 de setembro de 1897. Participou da Semana de Arte Moderna em 1922 e filiou-se ao Partido Comunista em 1928.

${ }^{154}$ Catedrático de Direito, político e jornalista, Hermes Lima nasceu em 22 de dezembro de 1902, em Livramento do Brumado, interior da Bahia. Depois de formar-se na Faculdade de Direito de seu estado natal, logrou ser admitido como livre-docente no Largo São Francisco em 1926 e depois ingressou, por concurso, na cátedra de Introdução ao Direito da Faculdade de Direito do Rio de Janeiro, em 1932. Em paralelo, perseguiu uma carreira política notável, sendo eleito deputado estadual e fazendo parte do secretariado do governador baiano Goes Calmon (1924-1927), junto com Anísio Teixeira. No Rio, era o porta-voz da Aliança Nacional Libertadora.

155 Escritor baiano nascido em 10 de agosto de 1912, passou sua infância em Ilhéus. Arquiconhecido por sua ligação com o Partido Comunista e seus romances sobre o sul da Bahia. Também foi aluno da Faculdade de Direito do Rio de Janeiro, formando-se na turma de 1935.

${ }^{156}$ Natural de Vassouras, interior do Rio de Janeiro, em 1888. Pertenceu ao gabinete de Hermes da Fonseca entre 1910 e 1912 e foi prefeito de Vassouras e deputado federal, até perder o mandato como punição por sua ligação com os movimentos operários. Fez parte dos levantes militares de 1922 e 1924, e por esse motivo foi preso. Apoiou a campanha de Getúlio Vargas em 1930, no bojo da qual se elegeu deputado federal. Manteve a proximidade com os tenentes até aderir à ANL em 1935.

${ }^{157}$ Educador baiano, também formou-se pela Faculdade de Direito do Rio de Janeiro em 1922. Depois de fazer um mestrado com temas educacionais nos EUA, participou do governo de Goes Calmon na Bahia, na condição de Inspetor Geral do Ensino da Bahia, passando logo depois a Diretor da Instrução Pública. Após a Revolução de 1930, foi secretário da Educação do prefeito da capital federal Pedro Ernesto e nessa condição tornou-se o principal arquiteto da Universidade do Distrito Federal.

${ }^{158}$ Natural de Cachoeiro do Itapemirim (ES) em 12 de janeiro de 1913, Havia estudado na Faculdade de Direito do Rio de Janeiro mas terminou por formar-se em 1932 na sua congênere de Belo Horizonte, onde já trabalhava como jornalista. Nesta condição, fez a cobertura da 
de Castro ${ }^{159}$, todos simpáticos à Aliança. Sua característica mais marcante era subverter a hierarquia das notícias do período, divulgando a atuação da própria Aliança Nacional Libertadora e a vida sindical do país de forma muito mais intensa e positiva do que os outros jornais. Inovou também em sua cobertura esportiva, mais importante e detalhada do que nos outros órgãos da imprensa. O jornal conquistou grande popularidade, chegando a ser um dos mais vendidos diariamente.

Em artigo que chama o plano nacional de educação de "fascista-clerical"160, o jornal faz uma crítica bastante irônica ao discurso do ministro no fechamento do congresso da Associação Brasileira de Educação ${ }^{161}$. A participação de Capanema indica sua tentativa de retomar o controle de uma instituição posicionada no epicentro das disputas em torno da educação do período e um indicativo político do que seria privilegiado em sua atuação como ministro. Nos comentários do jornal, Capanema é enquadrado como uma nulidade intelectual sempre disposta a agradar os representantes do Centro D. Vital, mesmo que isso signifique propor uma educação que sirva apenas para manter os pobres em sua condição inferior.

Os ataques receberam a resposta de Alceu em uma série de artigos coletados em um livro intitulado Da Tribuna e da Imprensa (LIMA, 1935) ${ }^{162}$. Na apresentação, Tristão menciona seu anseio de defender o país da ameaça de materialismo e apresentar uma leitura da história pátria que honrasse suas raízes cristãs. Preocupa-se também com o tipo de educação, pois ela comprometeria a formação de futuros cidadãos e profissionais do país.

Revolução Constitucionalista. Trabaou para o jornal Folha do Povo e A Manhã, ambos ligados à Aliança Nacional Libertadora. Por este motivo, foi preso diversas vezes pelo regime varguista. ${ }^{159}$ Nascido em Recife em 1908, formou-se médico em 1929, no Rio de Janeiro. Fez carreira acadêmica inicialmente no Recife (1932 a 1935) e em seguida no Rio de Janeiro, onde lecionou Antropologia na Universidade do Distrito Federal (1935 a 1938) e Geografia Humana na Faculdade Nacional de Filosofia (1940 a 1964).

${ }^{160}$ AS BASES fascistas-clericaes do plano nacional de educação, A Manhã, Rio de Janeiro, p. $1 ; 7,25$ jun. 1935..

161 “A Associação Brasileira de Educação foi fundada em 1924, por iniciativa de Heitor Lira. A ABE representou a primeira e mais ampla forma de institucionalizar a discussão dos problemas da escolarização, em âmbito nacional; em torno dela se reuniram as figuras mais expressivas entre os educadores, políticos, intelectuais e jornalistas, e sua ação se desdobrou na programação de cursos, palestras, reuniões, inquéritos, semanas de educação e conferências, especialmente as conferências nacionais de educação." Retirado de:

NAGLE, 1974, p. 123.

${ }^{162}$ Como o próprio nome indica, o livro é uma coletânea de discursos e artigos publicados na imprensa por Tristão. 
Ao comentar a criação de uma nova faculdade de Direto no Rio de Janeiro ${ }^{163}$, ele aproveita para criticar as universidades já existentes, por vários motivos. O primeiro é que elas facilitavam cada vez mais o ingresso de seus alunos, rebaixando as exigências intelectuais sobre seus alunos. Outro motivo seria a ideologia dos professores, tidos como "comunistas". Mas há uma terceira causa igualmente importante, com a qual estaria diretamente envolvido, na qualidade de professor que havia sido aprovado em um concurso na Faculdade de Direito do Rio de Janeiro, mas não em primeiro lugar:

\begin{abstract}
A Faculdade de Direito, então, sempre foi um refúgio dos displicentes. A situação hoje, aí como em toda a parte, só tem feito agravar-se. E os catedráticos agora o que pretendem, para aumentar possivelmente as rendas próprias (já que a sustentação da Escola está garantida pelo governo) é dificultar a entrada de... concorrentes no ensino, isto é, de livres docentes. Ainda há pouco recusou-se a Faculdade de Direito da Universidade do Rio de Janeiro a executar uma decisão unânime do Conselho Nacional de Educação, aprovado pelo ministro e pelo reitor, no sentido de serem considerados docentes livres todos os aprovados em concurso, acima de certo grau, como determinaram sempre as leis de ensino - provavelmente pela razão comercial inconfessada de não perderem certos catedráticos a "mina" das turmas suplementares, que lhes multiplicam os ordenados... (LIMA, 1935, p. 184-185)
\end{abstract}

Nesse mesmo artigo, Amoroso Lima abordava também o problema da superabundância de diplomas universitários e a dificuldade dos novos formandos em encontrar uma colocação coerente com a sua formação. Além disso, a composição do corpo docente destas universidades abrigaria um "bric-a-brac jurídico, onde todas as correntes ideológicas se acotovelam", formando novas elites da Justiça e da burocracia sem a menor coerência entre elas. No interior desta torre de babel um grupo se destacaria: o materialismo jurídico, que em suas palavras “(...) é a substituição da Justiça pelo Arbítrio Revolucionário, no fundamento do Direito - é o Estado Liberal que oficialmente prepara os seus próprios destruidores".

A suposta necessidade de uma composição homogênea do corpo docente seria assunto retomado em outro artigo ${ }^{164}$, visando exclusivamente Anísio Teixeira e sua defesa do espírito liberal da nova Universidade do Distrito Federal, que poderia acolher representantes de todas as correntes de pensamento. Amoroso Lima considerava que

${ }^{163}$ LIMA, Alceu Amoroso. Escolas de Direito. In: Da Tribuna e da Imprensa. Petrópolis: Vozes, 1935, p. 183-188.

${ }^{164}$ LIMA, Alceu Amoroso. Universidade ou poliversidade? In: Imprensa. Petrópolis: Vozes, 1935, p. 194-198. 
tanto o liberalismo quanto o socialismo estariam distantes do único e verdadeiro espírito universitário, presente desde a fundação da primeira universidade pela Igreja no período medieval, e traduzida na constituição dos studium generale ${ }^{165}$. No Brasil, os vitalistas estariam buscando recuperar este sentido, mas enfrentavam a resistência de gente como Anísio Teixeira:

\begin{abstract}
Para o reitor da Universidade Municipal, a sociedade é composta de instituições independentes e soberanas entre si, que vivem completamente "separadas" umas das outras. É uma tese pluralista, no mais alto grau, que arrastaria a sociedade, se levada às suas consequências lógicas, a um particularismo institucional não menos anarquizante que o individualismo moribundo. E na mesma hora em que o reitor da Universidade fazia assim a sua profissão de fé liberocultural, a comissão encarregada de estudar o plano universitário federal, contra o voto vencido do sr. Jonathas Serrano, decapitava a futura Universidade Federal, privando os crentes da liberdade de nela possuírem uma Faculdade de Teologia, que Newman mostrou ser o coroamento de todas as Universidades dignas de tal nome, pela universalidade dos seus domínios (LIMA, 1935, p. 198). ${ }^{166}$
\end{abstract}

Na passagem acima Alceu escreve a favor dos interesses de seus dois chefes políticos: o Cardeal Leme e o Ministro Capanema, dos quais Anísio Teixeira quer igualmente se desembaraçar na condução de seu projeto universitário. A crítica à defesa da autonomia e ao corte da faculdade de teologia são duas partes de um mesmo processo.

O dia-a-dia das universidades foi também o tema do periódico dos membros da Ação Universitária Católica: A Vida. Nele há diversos textos de alunos a demonstrar a obsessão com a qual perseguem o objetivo de extinguir as aulas sobre certas teorias sociais, vistas como contrárias à fé (liberalismo e comunismo). Para José Pedro Galvão Souza ${ }^{167}$, o problema não seria o marxismo, mas o liberalismo ensinado pelos docentes. Já na edição seguinte (maio de 1934), aparecem dois textos de crítica ao suposto smo

\footnotetext{
165 A expressão studium generale pode designar tanto a matéria ensinada nos currículos das universidades medievais quanto as instituições que recebiam das autoridades o direito de abrigar cursos universitários. Em ambos os casos, o que Alceu pretende ressaltar é o caráter completo destes estudos, isto é, sua capacidade de resolver todos os aspectos da realidade.

${ }^{166}$ John Henry Newman foi um sacerdote anglicano convertido ao catolicismo. Sua conversão teve caráter marcadamente intelectual, originada de sua apreciação da teologia do catolicismo, segundo ele mais fiel ao espírito do cristianismo primitiva. Escreveu principalmente sobre a necessidade de desenvolver os dogmas da fé a partir da reflexão teológica. Nasceu em Londres, em 1801 e faleceu em Edgbaston, 1890.

167 SOUZA, José Pedro Galvão, Tendências políticas da mocidade católica, Vida Revista
} Universitária, ano 1, n. 1, abr. 1934. 
dos professores. No primeiro deles, Leonidas Resende é textualmente citado, enquanto o segundo aborda a universidade de uma forma geral. Resende era um dos principais professores da Faculdade graças à sua liderança sobre o conjunto de autores marxistas. Souza propõe simplesmente que qualquer defesa do marxismo em sala de aula deveria ser considerada como um crime de segurança nacional ${ }^{168}$, mas sua proposta não parece receber continuidade dos outros autores.

Outro eixo estruturante da revista é o relato das atividades da Ação Universitária Católica, entre as quais se destacam o núcleo de liturgia e as equipes sociais. Do primeiro faziam parte monges beneditinos e jovens universitários, que relatam em seus textos a surpresa de poderem atuar lado a lado com os religiosos nas cerimônias dedicadas ao grupo. As equipes sociais consistiam em reuniões semanais entre um universitário e uma equipe de operários. Os aucistas se advogam um papel missionário de levar a verdadeira cultura aos lares dos trabalhadores manuais e acreditam que, na ausência do trabalho deles, os comunistas facilmente lograriam o domínio sobre os operários. Com efeito, universitários e operários eram o público-alvo dos comunistas. Mas o escopo de temas tratados era mais amplo e envolvia a crítica aos aspectos de modernidade presentes em todos os níveis do ensino, como por exemplo a educação sexual nas escolas.

Nem todos os vitalistas apresentam uma visão tão pessimista sobre os rumos da educação no período. Jônathas Serrano, por exemplo, escreve uma obra cujo título e subtítulo já são por si mesmos bastante indicativos: A Escola Nova - uma palavra serena em um debate apaixonado. O livro procurava dialogar com algumas inovações propostas pela Escola Nova, relativizadas e circunscritas a um limite de alterações que não chegavam a tocar na questão central capaz de diferenciar o ensino católico dos escolanovistas: a visão do homem como ser transcendental e, consequentemente, do privilégio conferido ao ensino da religião.

Neste aspecto, o livro se mantinha disciplinadamente católico. Ao mesmo tempo, Serrano procurava demonstrar como boa parte dos educadores do movimento da

\footnotetext{
${ }^{168}$ Respectivamente:
}

SOUZA, José Pedro Galvão. Atividades universitárias, Vida Revista Universitária, ano 1, n. 2 , maio 1934.

ROCQUE, Francisco Augusto de la, O comunismo universitário e a liberdade de cátedra, Vida Revista Universitária, ano 1, n. 2, maio 1934. 
Escola Nova eram católicos ou simpatizantes a esse tipo de ensino. Apenas um pequeno grupo destes novos pedagogos (Anísio Teixeira, por exemplo) poderiam ser considerados inimigos do ensino religioso. Sobre ele incidia a acusação de má vontade na aplicação do decreto de abril de 1931. Também é importante destacar o que não aparece no livro: por exemplo, a aproximação da Escola Nova com o comunismo ou a discussão sobre o tipo de acesso ao ensino, se público ou privado.

Após comentar a situação de Jônathas Serrano, completa-se o círculo de pontos de vista diferentes mas igualmente relevantes para a compreensão de como o Centro era visto por diversos outros atores relacionados a ele, ainda que essa relação fosse marcada pelo desacordo e pela disputa. Sua força ficou registrada de forma clara, porém indireta, pelas críticas que o grupo recebeu à medida que suas posições eram formuladas em espaços públicos estratégicos - no Ministério da Educação, na Faculdade de Direito do Rio de Janeiro, etc. Nos anos 1940, os artigos de crítica aos vitalistas desaparecem completamente. Em meio ao clima do Estado Novo, é presumível que os pontos de vista mais próximos ao liberalismo e ao comunismo não encontrariam espaço para se manifestar. Não obstante a ausência de seus inimigos tradicionais, o Centro Dom Vital não alcançaria o mesmo sucesso de imprensa que havia conquistado na década anterior. Os anúncios de suas atividades continuavam a ser publicados semanalmente; o que faltava em relação aos anos 1930 eram os outros tipos de manifestação, mais espontâneos e mais detalhados em suas considerações - críticas literárias, etc.

Em paralelo ao debate sobre o ensino religioso, discute-se o tipo de ciência a ser privilegiado, com o esforço dos vitalistas em apresentar seu próprio modelo. Ela consistiu em exemplos de pesquisadores que considerassem seu ramo de conhecimento incompleto e coroassem a teologia como o conhecimento supremo, construído não em oposição às ciências, mas como seu complemento e guia. Em Preparação à Sociologia ${ }^{169}$, Amoroso Lima, por exemplo, dividia a sociologia em "filosofia social", "ciência social" e "arte social".

A filosofia social consistiria em "deduzir os princípios cardeais que governam a constituição e o desenvolvimento da ciência da sociedade" enquanto a ciência seria responsável por "observar a sociedade, fixar os fatos sociais, recolhê-los, classificá-los

169 LIMA, Alceu Amoroso. Preparação à sociologia. Rio de Janeiro: Editora Centro Dom Vital, 1931. 
de modo a alcançarmos um conhecimento objetivo e impessoal desses fenômenos". A arte social consistiria na "aplicação prática dos princípios estudados pela filosofia social e dos fatos recolhidos pela ciência social". Uma boa sociologia se definiria como “cristã" e deveria renegar o embate entre o Estado e o indivíduo, pois ambos existem para servir aos grupos intermediários - a família, o sindicato, a escola e a Igreja - cujo direito de existir deveria ser respeitado e protegido por ele. Esta concepção de sociologia atraiu o interesse da Igreja. Dentro desta tese, ela seria concebida como o depositário de uma ordem social estabelecida por uma força superior a ela própria, da qual nasce todo o direito e a autoridade, inclusive a do Estado. Norma Côrtes ${ }^{170}$ desenvolveu este raciocínio do ponto de vista de como esta obra (e outras que seguiram o mesmo raciocínio) realizaram uma atualização da filosofia tomista a partir do pressuposto básico de que sociologia deveria confirmar a inteligibilidade do mundo a partir da aplicação dos princípios básicos do tomismo, dos quais resultavam leis comprováveis empiricamente.

Por outro lado, a concepção de sociologia de Amoroso Lima confiava os princípios básicos de sua ciência ao que chamava de "filosofia" e "arte social". Esta seria o resultado do diálogo entre as descobertas da ciência e as especulações teológicas sobre o modelo de sociedade ideal. Em última instância, a sociologia seria uma forma de saber dedutiva, construída sobre o alicerce de um pensamento político autoritário na medida em que menosprezava a vontade popular como fonte de erros e queria encontrar na doutrina social da Igreja o guia infalível para um comando centralizador. Neste quebra-cabeças, a sociologia seria a peça que o Estado precisa para suprir-se das ferramentas necessárias para um bom governo, o que incluiria uma compreensão dos seus limites de atuação.

Oliveira Vianna desenvolve considerações a respeito desse tipo de sociologia em sua resenha crítica de Preparação à Sociologia. Após as gentilezas de praxe, com descrições em tom elogioso da obra, revela uma oposição ao tipo de ciência social que Amoroso Lima pretende construir. Segundo ele, seria necessário encabeçar um tipo de conhecimento mais empírico, tal como definido na passagem abaixo:

\footnotetext{
${ }^{170}$ CÔRTES, Norma. Católicos e autoritários: breves considerações sobre a sociologia de Alceu
} Amoroso Lima, Revista Intellectus, Ano I, n.1, p. 1-14, 2004. 
$\mathrm{O}$ que eu esperaria para o Brasil era uma atividade complementar desse belo labor dos nossos filósofos sociais. Era, nos estudiosos com o gosto da investigação, um apelo mais frequente aos métodos científicos de pesquisas, uma preocupação mais sistemática pelos problemas objetivos. Em suma, uma sorte de gravitação para o concreto da parte dos espíritos que aqui se dedicam aos estudos das ciências sociais. ${ }^{171}$

Mesmo se em primeiro nível Vianna aceita e valoriza o tipo de escrita desenvolvido por Amoroso Lima, seu comentário final nos conduz ao raciocínio de que para ele a sociologia era algo bastante distinto. Designar um autor com a alcunha de "belo filósofo social" equivalia a desqualifica-lo como sociólogo na plena expressão do termo, pois não havia alcançado o nível de maturidade intelectual para tanto. Como demonstraram os exemplos de Oliveira Vianna e Oswald de Andrade, as críticas ao tipo de sociologia feita por Alceu partem tanto da tradição modernista paulista quanto da corrente sociológica originada no Rio de Janeiro, a partir de intenso diálogo com os debates políticos da capital federal.

A sociologia não foi o único território acadêmico a ser objeto das invectivas do grupo de vitalistas; na filosofia, eles também marcaram presença através de um conjunto não desprezível de obras. O elemento aglutinador delas era a afirmação do neotomismo como a visão teórica oficial do grupo. Ou seria talvez mais apropriado escrever "neotomismos", no plural, em respeito às suas divisões em correntes distintas e ao diálogo entre elas. $\mathrm{O}$ apoio de distintos papas ao movimento não impediu seu desdobramento em faces distintas, de acordo com sua maior ou menor capacidade de dialogar com a modernidade, ou com a ênfase em uma leitura agostiniana de Santo Tomás frente à possibilidade de realçar seus aspectos aristotélicos. Na França, a recorrência a S. Tomás possuía também um caráter nacionalista, de oposição à filosofia alemã.

Maritain estabelece pontes entre sua produção e a de Maurras ao assumir, nos primeiros anos da década de 1920, a participação em iniciativas do grupo, notadamente a Confédération professionnelle des intelectuels catholiques (1920). Nestes espaços de sociabilidade, os dois partilharam a defesa de projetos corporativistas de organização

\footnotetext{
${ }^{171}$ VIANNA, Oliveira. Os Estudos Sociológicos do Brasil, Hierarquia, Rio de Janeiro, ano 1, v. 1, p. 14-15, ago. 1931.
} 
social, e a submissão dos indivíduos e dos grupos sociais à Igreja. Eles reapareceriam no Brasil dos anos 1930, pelas mãos de Amoroso Lima.

Quando a Action Française é condenada em 1927, a força dessa versão de neotomismo já se encontrava bastante reduzida. Maritain, por exemplo, escrevia mais sobre outros assuntos, na esteira de uma série de textos iniciada por "Art et scolastique" (1919), no qual defendia um conceito de arte capaz de conciliar a pesquisa estética com um sentido de moral para a arte. Esta nova proposta encontrou uma boa recepção entre os artistas franceses de vanguarda, enfraquecendo o tom passadista da Action Française. Sua condenação em 1926 ajudou a apagar sua importância na América Latina e ressaltar a de Maritain $^{172}$.

A baixa quantidade de obras produzidas pelos vitalistas sobre a Action Française é um indício de que a disputa não se localizava neste terreno, pois a hegemonia de Maritain estava assegurada, como demonstram a recorrência de seu nome nos escritos e nas aulas proferidas pelos vitalistas. Estas ocorreram por exemplo no âmbito do Instituto Católico de Estudos Superiores, no qual Alceu Amoroso Lima mantinha o curso de Sociologia, enquanto Sobral Pinto era o responsável pelas aulas de Direito e Hamilton Nogueira, pelas de biologia e antropologia. As aulas ocorriam no prédio do Centro. Maria Hermínia Tavares Almeida (2001) ressalta como o Instituto foi importante instrumento na consolidação de uma hegemonia da Igreja sobre o mundo universitário, a se iniciar pela Faculdade Nacional de Filosofia - incursão dos católicos em uma instituição estatal - e findando com a criação da PUC-RJ.

A disputa em torno do que poderia ser considerado como um esforço intelectual de qualidade não permaneceu despercebida pelos críticos do Centro Dom Vital, especialmente por aquele que viria a ocupar a linha de frente também neste assunto: $A$ Manhã. As críticas presentes no jornal compõem uma linha editorial bem delineada: minar a credibilidade dos vitalistas na cena cultural brasileira. Embora não fossem exclusivamente voltadas a Amoroso Lima, era ele o nome mais visado. Uma das estratégias que rendeu mais frutos foi a acusação de que os funcionários de sua empresa de fiações (Cometa) eram expostos a condições insalubres de trabalho, especialmente para as mulheres ${ }^{173}$. A acusação visava explicitamente desacreditar a defesa do

172 CHENAUX, Philippe. Entre Maurras et Maritain : une génération intellectuelle cathilique (1920-1930). Paris : Les Éd. du Cerf, 1999.

${ }^{173}$ SUCUPIRA FILHO, Eduardo. Com que roupa, A Manhã, Rio de Janeiro, p. 3, 05 jun. 1935. MOREYRA, Alvaro, Olha a frente, A Manhã, Rio de Janeiro, p. 3, 11 jun. 1935. 
sindicalismo cristão, com a qual Amoroso Lima estava associado. Em artigo de 1935, Oswald de Andrade não dispensa o uso de linguajar chulo para caracterizar as pretensões do grupo:

Em longas exéquias a existência do Sr. Tristão de Athayde é uma simples missa de corpo presente no recinto desse variado e imenso Moinho do Jeca que é a Santa Madre Igreja. Em torno do blindado corifeu do neotomismo, soluçam as vacas capadas da alta, os jacarés falantes do integralismo, os jumentos de quatrocentos anos e mais a cabralhada vadia que entre tochas enfeita o lusco-fusco da nossa tragédia colonial. ${ }^{174}$

Em linguagem altamente irônica e agressiva, consegue unir as preferências filosóficas de seu desafeto (o neotomismo) com o público ao qual se destinavam suas preleções: os integralistas, uma aristocracia surda aos apelos do modernismo artístico, do tenentismo e do comunismo (os jumentos de quatrocentos anos) e um grupo de pretendentes a intelectual de qualidade abaixo da crítica, esperando alguma oportunidade de se firmar na cena pública (a "cabralhada vadia") ${ }^{175}$. A "tragédia colonial" pode ser interpretada como a influência que o catolicismo possuía na vida social brasileira.

A questão dos pretendentes a algum destaque reaparece em outros artigos escritos sem a mesma verve do autor de Serafim Ponte Grande, mas que engrossaram o coro dos descontentes com os vitalistas. Hermes Lima, candidato vencedor no concurso para a cátedra de Introdução ao Direito ao qual Alceu Amoroso Lima também havia se apresentado, afirma que seu nome era objeto de uma perseguição intensa por parte de alunos e colaboradores da imprensa católicos, insatisfeitos com a condição de relegados da Universidade do Distrito Federal.

${ }^{174}$ ANDRADE, Oswald de. Só para homens, A Manhã, Rio de Janeiro, 19 maio 1935. De literatura, p. 6.

${ }^{175}$ Oswald de Andrade não é o único a usar a figura de um quadrúpede para designar de forma vulgar a figura do vitalista que enxerga no Centro uma possibilidade de ascensão. Em:

FONSECA, Gondin da. A segunda encarnação dos Incitatus, Correio da Manhã, Rio de Janeiro, p. 4, 22 dez. 1935.

Gomes é comparado ao cavalo feito senador por Calígula. Vai além ao dizer que Gomes utilizou-se da boa-fé de Jackson de Figueiredo para fingir-se de convertido e assim poder vir ao Rio de Janeiro em busca de um emprego. 
Hermes e Tristão encarnavam os dois polos da disputa ideológica do período, pois o primeiro se aproximara da ANL e colaborava regularmente com seu jornal. Além disso, era dono de uma carreira bastante considerável na universidade, tendo ocupado o cargo de professor na Faculdade do Largo São Francisco, em São Paulo, antes do concurso carioca. Este era um contraponto importante a um outsider como seu adversário, sem experiência docente em nível universitário naquele momento, mas que procurava a qualquer custo lutar por seu ingresso na Universidade. A formação deste corpo docente se tornava uma questão de defesa da liberdade de expressão:

\begin{abstract}
Os porta-vozes do clericalismo nas assembleias políticas, nos jornais acabam, ainda agora, de abrir campanha contra a nomeação de certos professores para a Universidade do Distrito Federal sob a alegação de que tais professores são comunistas e professam ideias extremistas. É o recurso, velho recurso, aliás, de que a Igreja lança mão para combater as conquistas da cultura humana, para impor seus dogmas, para eliminar o livre exame de instituições e princípios, oferecendo ao Estado a realização de uma aliança para a defesa intransigente, com mão de ferro dos interesses dominantes que temem a liberdade do pensamento. ${ }^{176}$
\end{abstract}

Estes mesmos embates aparecem em outros jornais do período, como o Correio da Manhãa, ${ }^{177}$ que contribui para essa campanha de diminuição da importância dos vitalistas (e especialmente de Amoroso Lima) através dos artigos de Heitor Lima ${ }^{178}$.

\footnotetext{
${ }^{176}$ LIMA, Hermes. A ofensiva clerical, A Manhã, Rio de Janeiro, p. 3, 31 maio 1935.
}

${ }^{177}$ Para os propósitos atuais da pesquisa, o importante do jornal é ressaltar que se tratava de um jornal de opinião, portanto aceitava diversas correntes e permitia a elas se manifestarem. $\mathrm{O}$ interessante é que este grupo apoia a aliança liberal durante a campanha de 1929 e critica Getúlio Vargas por sua declaração de aceitar a derrota. Sobre o jornal, Nelson Werneck Sodré escreve em sua História da imprensa no Brasil:

"O Correio da Manhã vinha romper, efetivamente, o cantochão de louvores ao governo Campos Sales que presidia a política de estagnação, onerando terrivelmente as classes populares. Quebrava a placidez aparente, alcançada pelo suborno, pela sistematizada corrupção, institucionalizada a compra da opinião da imprensa. Quebrou a monótona uniformidade política das combinações de cúpula, dos conchaves de gabinete; levantou sempre o protesto das camadas populares, na fase histórica em que a participação da classe trabalhadora era mínima. Através desse caminho, vindo de baixo, portanto, é que se transformou, e depressa, em empresa jornalística." (4 Edição, RJ, Mauad, 1999, p.287)

${ }^{178}$ LIMA, Heitor. O divórcio na constituinte, Correio da Manhã, Rio de Janeiro, p. 2, 02 maio 1934.

LIMA, Heitor. Pela Verdade. Correio da Manhã, Rio de Janeiro, p. 2, 18 out. 1933. 
Este autor era um advogado e delegado de polícia, exercendo a crítica literária e de teatro como sua segunda atividade. Sua relação com os vitalistas é sempre de oposição e se espalha por diversos temas: do apoio ao divórcio, passa a estabelecer um questionamento irônico sobre a qualidade da produção intelectual de alguém como Tristão de Athayde, que em suas palavras parece mais preocupado com a qualidade das meias que produz, em nova referência à sua empresa familiar. Essa atuação é complementada pela de Cândido Jucá Filho ${ }^{179}$, atento à crítica ao estilo de Tristão, considerado por ele como muito confuso e dotado de metáforas esdrúxulas. Um exemplo disso é o livro chamado Esboço de uma introdução à economia moderna, que para Jucá Filho conduz a uma visão equivocada da Idade Média ${ }^{180}$ como um período sem exploração dos trabalhadores e marcado pela harmonia social.

O embate do jornal A Manhã se estenderia a outros alvos: Jorge de Lima e Murilo Mendes, pertencentes ao grupo de poetas espiritualistas cultuados pelas páginas de $A$ Ordem e de Vida, nas quais estariam presentes muitos de seus poemas. Os dois publicam juntos Tempo e eternidade, livro de fundo místico que lhes valeu a indicação como segundo lugar no concurso promovido pela Sociedade Felippe d'Oliveira ${ }^{181}$. Menção bem menos honrosa foi conferida a eles por Rubem Braga, outro colaborador de $A$ Manhã. Seu artigo ${ }^{182}$ apresenta de forma cristalina a disputa pela definição do que deve ser considerado como literatura.

Para Rubem Braga, o livro é uma "idiotice” escrita por dois poetas que preferem ficar "por cima de uma torre de concreto contemplando o céu ao invés de ver a luta na

LIMA, Heitor. Réplica a um mercador de meias. Correio da Manhã, Rio de Janeiro, p.2, 10 out. 1929.

LIMA, Heitor. Um grande cidadão, Correio da Manhã, Rio de Janeiro, p. 2, 07 nov. 1934.

${ }^{179}$ Nasceu no Rio de Janeiro a 2 de setembro de 1900. Bacharelou-se pela Faculdade de Direito desta cidade mas enveredou pelos estudos de literatura e filologia. Fundou e presidiu a Sociedade Brasileira de Filologia.

180 JUCÁ FILHO, Candido. Um livro grande de sociologia. Correio da Manhã, Rio de Janeiro, p. 2,17 out. 1930 .

${ }^{181}$ A Sociedade Felippe d'Oliveira foi criada por João Daudt d'Oliveira, que também auxiliou materialmente na fundação da PUC-RJ, a pedido de Leonel Franca. Amoroso Lima viria a fazer parte dessa sociedade em 1935, após a morte inesperada de Ronald de Carvalho. Sobre a sociedade, conferir: GOMES, Angela de Castro. Essa gente do Rio. Rio de Janeiro: FGV, 1999.

${ }^{182}$ BRAGA, Rubem. Tempo e eternidade, A Manhã, Rio de Janeiro, p. 3, 30 jul. 1935. 
terra". Define ainda a boa cultura como uma ferramenta de conscientização dos trabalhadores, ao contrário do que fazem os dois autores, cuja obsessão pelo tema da transcendência conjuga-se ao uso de temas sutilmente eróticos. A conclusão é uma lembrança aos dois autores de que se esquecem das mulheres operárias, cujos corpos tornam-se feios depois de tanta exploração social para produzir a mais valia que permite ao capitalista manter a beleza indefectível de sua mulher, retratada e elogiada pelos poemas do livro. Em resumo, a postura de $A$ Manhã não admite nenhuma condescendência com os vitalistas, considerados conservadores e despregados da realidade social do país.

No que diz respeito aos textos produzidos pelos próprios vitalistas, é possível notar divisão estrita de tarefas a partir do cotejamento dos escritos de Leonel Franca com os de Jackson de Figueiredo ou Amoroso Lima, entre os quais existe certo grau de complementaridade. O papel de Franca é organizar os fundamentos filosóficos do grupo, enquanto Jackson (e, após sua morte, Amoroso Lima) vão traduzir o que significam estes fundamentos na seleção de quais obras artísticas e literárias merecem o conhecimento e o apoio dos católicos, e quais são aquelas que não merecem. No que diz respeito à defesa do ensino religioso nas escolas públicas, a hierarquia entre os autores é menos visível; os autores se repetem uns aos outros em seus argumentos e a opção deles é publicar no leque mais aberto possível de órgãos da imprensa para marcar posição. Tanto em uma como em outra condição, é notável o esforço dos três autores para impedir a revelação de qualquer tipo de combate entre eles. Jackson de Figueiredo, o escritor mais prolífico sobre o tema da trinca, faz constantemente menção a Franca como o seu guia maior. Amoroso Lima não demonstra a mesma reverência e nem parece disposto a enfrenta-lo.

A série de livros que Figueiredo publicou ao longo da década de 1920 revela um autor preocupado com diversas frentes de atuação, mesmo no campo da cultura: o filósofo que apresenta um Pascal feito sob medida para o público moderno também é o crítico a avalizar as obras literárias de acordo com o valor que elas representam para a difusão dos princípios morais da ortodoxia católica. O crítico do pragmatismo e do materialismo de Afrânio Peixoto está lado-a-lado com o escritor preocupado em definir qual é o caminho para a afirmação da identidade nacional no Brasil e em outros países da América Latina. Jackson é o homem que ataca em todas as frentes de atuação, mas 
não fixa sua atenção em nenhuma delas. De todas estas obras, nasce um Jackson de Figueiredo multifacetado.

Em Afirmações (1921), Figueiredo analisa a história da literatura brasileira. Dedica o livro para Alceu Amoroso Lima, pessoa "a quem eu amo e admiro", segundo suas próprias palavras. Ele se diz consciente de que o único critério adotado para avaliar a literatura foi a certeza de que tudo que existe de positivo na civilização ocidental é criação da Igreja Católica. A análise da literatura brasileira se dá por meio da visão pontual sobre alguns autores, sem estabelecer diálogos diretos com a crítica préexistente. Ele deseja reconstruir a história da literatura nacional a partir de outros critérios, a começar pela conformidade dos autores estudados com a doutrina católica. Por este motivo, em seu panteão de autores nacionais não há espaço para Machado de Assis e sua verve cética e irônica, mas Xavier Marques merece destaque pela mística e transcendência de seus poemas ${ }^{183}$. Em paralelo com sua análise da literatura, Jackson de Figueiredo também dialoga com Afrânio Peixoto. Ele considera a filosofia deste autor muito inspirada pelo materialismo e pelo pragmatismo e por isso prejudicial à análise do sentimento religioso que aquele autor deseja empreender, pois se nega a aceitar os evidentes (segundo Jackson) benefícios que a religião pode trazer. Jackson de Figueiredo também repreende em Afrânio suas críticas ao caráter brasileiro, que Jackson enxerga como sendo, na verdade, problemas da herança que os portugueses deixaram no país.

Em Literatura Reacionária, reunião de diversos artigos publicados na imprensa carioca ao longo do ano de 1924, Figueiredo volta suas atenções para os nomes que povoam seu universo de referências e de modelos de pensamento. Com Ronald de Carvalho e Tristão de Athayde, o debate é sobre a função da arte e a necessidade de que ela esteja relacionada à moral e à defesa da ordem. Seus colegas de Centro Dom Vital também não deixam de ser citados, a começar por Leonel Franca, cujo elogio à segunda edição de Noções de História da Filosofia o eleva ao estatuto de obra criadora de uma tradição da filosofia católica no Brasil:

O padre Leonel Franca é, como disse, autor de uma "História da Filosofia", de que a segunda edição constituía, por assim dizer, a sua

\footnotetext{
${ }^{183}$ Francisco Xavier Ferreira Marques nasceu na ilha de Itaparica (BA), em 1861, mas aos vinte anos mudou-se para Salvador, onde lecionava e escrevia em diversos jornais. Em 1918, é eleito para a Academia Brasileira de Letras e em 1921 elegeu-se deputado federal pela Bahia. Colaborou também em diversos periódicos do Rio de Janeiro. Faleceu em Salvador (BA) em 1942. Seu estilo rigorista foi a causa de seu infortúnio após as inovações do modernismo.
} 
revelação ao mundo das letras brasileiras. (...) talvez só por modéstia não deu em volume à parte as últimas cem páginas que são, realmente, a primeira tentativa séria de uma história das ideias no Brasil, de uma história e de uma crítica dessas mesmas ideias, do ponto de vista de um sistema com direito de cidade no mundo da filosofia, no caso, graças a Deus, o da filosofia tradicional, católica. (FIGUEIREDO, 1924, p. 29)

No trecho acima, Figueiredo refere-se à grande inovação da obra de Franca em sua segunda edição, datada de 1921: a inclusão de um capítulo final sobre a história da filosofia no Brasil, em um cenário editorial brasileiro bastante pobre de iniciativas deste tipo. Outro assunto mencionado no trecho e de fundamental importância para a construção teórica do próprio Figueiredo era o diferencial que ele encontrava na filosofia católica, com sua elevação do ramo da moral à condição de superiora a todas as demais no campo da filosofia. Toda ação humana apresentaria alguma consequência, boa ou má, inclusive a obra de arte. E para realizar a avaliação moral da obra, o único guia confiável seria a doutrina moral católica. Na conclusão de Figueiredo, a avaliação moral adquire paridade de importância com a questão estética.

Figueiredo aplica um raciocínio semelhante à sociologia, a partir das considerações de Bureau, parâmetro para medir como deveria ser um bom sociólogo cristão, isto é, aquele cujo aspecto moral da obra também poderia ser valorizado:

Bureau, para quem a ciência era sempre amoral, julgava que a sociologia poderia ser organizada como outra qualquer ciência, mas "completada" pela "arte social", "a arte de conduzir as instituições sociais", de "dirigir a ação humana", porque o espírito humano - dizia ele - "jamais fica inteiramente separado das aplicações práticas" (FIGUEIREDO, 1924, p. 162-163).

$\mathrm{O}$ acerto de Bureau estaria no equilíbrio deste novo conceito de sociologia, capaz de evitar dois extremos. Entre as teses que conferiam um peso exagerado a atores impessoais e outras a proclamar a força das grandes individualidades como formadoras de uma sociedade, Bureau teria permanecido "no meio termo aconselhado há séculos pela Igreja Católica (...) afirmando ainda a existência de uma lei moral transcendente."

Em seu compêndio de Filosofia, Leonel Franca discutiu as condições para a emergência de uma filosofia cristã e estabeleceu uma hierarquia entre os filósofos. Os pensadores brasileiros anteriores a Farias Brito estariam na parte mais baixa dessa hierarquia. Para Tobias Barreto, existe até uma cerca condescendência tendo em vista 
que ele aceita a presença de um padre em seu leito de morte, ato interpretado como uma aceitação da validade da religião. Ao contrário destes autores, Farias Brito é visto como o modelo de intelectual a ser reproduzido, pois seu sistema filosófico permite conceber ligações com a metafísica religiosa e transformar a filosofia em antessala da teologia.

Leonel Franca apresentou uma clara inflexão entre o início da década de 1930 e o final dos anos 1940, tal como registrado em seus livros de polêmica e na coletânea Alocuções e artigos. Há dois artigos escritos no final da década de $1920^{184}$ nos quais a preocupação primordial era demonstrar as virtudes e a atualidade do tomismo frente aos desafios da filosofia contemporânea. Sintomaticamente, nenhum dos estudos indica referências brasileiras e estabelece um diálogo direto com os neotomistas da Europa.

Nos anos 1940, a preocupação principal de Franca é a mesma no campo da política e da economia: enfrentar o comunismo ${ }^{185}$. Entretanto, a maneira como o problema é enxergado muda consideravelmente: deixa de ser a perseguição religiosa ipso facto e torna-se uma suposta indigência cultural, fruto de um materialismo que acreditaria ser mais importante para o ser humano dedicar-se às atividades materiais que às do espírito. Em meio a estes extremos, um marco importante é a publicação de $A$ Crise do mundo moderno, em 1941, publicado pela Editora José Olympio.

O indício de que a obra se voltava para um público mais amplo é confirmado por sua estrutura interna, que sem abrir mão de uma apologia da Igreja católica, volta-se para um leitor que não estava acostumado com esta doutrina. A estrutura do livro obedece a uma estrutura dialética, apresentando em primeiro lugar a tese, isto é, o conceito de sociedade e o motivo de sua crise atual. Em seguida, vem a antítese, que são as causas da crise da civilização. Dali em diante descortinam-se Lutero, Descartes, Rousseau, Marx e Nietzsche, cada qual à sua maneira, destroçando a harmonia que havia na sociedade cristã. Leonel Franca não pretende voltar a constituir uma sociedade tal como aquela do medievo, mas considera que naquela época havia uma completa

184 “A história da filosofia na doutrina de S. Tomás de Aquino", EM: Revista de Cultura (maio
de 1927), pp. 78-104. Apud: FRANCA, Leonel. Alocuções e artigos. Rio De Janeiro: Agir,
1954.
"Caracteres fundamentais do tomismo" EM: A Ordem (setembro de 1929), pp. 9-32. Apud:
FRANCA, Leonel. Alocuções e artigos. Rio De Janeiro: Agir, 1954.
185 "Ateísmo militante", Verbum (setembro de 1945), pp. 33-58. Apud: FRANCA, Leonel. Alocuções e artigos. Rio De Janeiro: Agir, 1954. 
harmonia social, sem abrir espaços para a manifestação de interesses individuais, e, portanto, do conflito.

Com uma erudição incomum, Franca é capaz de estabelecer uma genealogia do conceito de indivíduo, a se iniciar pelo cogito cartesiano. Em resumo, seu raciocínio é de que todas as correntes filosóficas europeias da Idade Moderna (a filosofia francesa, o deísmo inglês ou o iluminismo alemão) contribuem de alguma forma para diminuir o reconhecimento de uma dimensão transcendental no homem e, ao mesmo tempo, deificá-lo. A lógica de apresentação dos argumentos resguarda uma interpretação bem informada dos pressupostos e das conclusões que cada uma dessas escolas apresenta. Por exemplo, ao lembrar que com Descartes a existência dos indivíduos passa a ser pensada a partir deles próprios e não mais como um pertencimento a uma comunidade, ou como a ética kantiana estabelece como critério para a valoração do que é eticamente justo ou não a racionalidade dos próprios sujeitos.

O elemento novo trazido por Franca consiste na valoração deste percurso do pensamento como negativo, deletério à humanidade, e em certa medida a apresentação dos principais nomes do materialismo do século XIX - Comte, Nietzsche e Marx, nessa ordem de apresentação - como um todo coerente entre as partes, fundando a leitura de que a filosofia do século XIX transformou o ser humano em deus de si próprio. No terceiro e último capítulo Franca apresenta a síntese, isto é, a única instituição capaz de superar o problema armado nos dois capítulos anteriores: a Igreja, representante única e exclusiva do cristianismo.

O primeiro capítulo desta última parte do livro de Franca se inicia com a apresentação do conceito de "pessoa", que deveria substituir a ideia de indivíduo. Inspirado pelo conceito de personalismo por Emanuel Mounier, Franca pretende refazer o equilíbrio nas relações entre as sociedades e seus membros a partir da afirmação de uma relação de direitos e deveres. Ao contrário da pregação iluminista, muito centrada na ideia de que os indivíduos têm seus direitos assegurados, Franca quer defender a contrapartida, isto é, os deveres que ele possui. Na sequência de seu texto, Franca apresenta os benefícios que, segundo ele, só a presença da Igreja na história da humanidade poderia causar, liberando os homens do jugo da escravidão presente no mundo antigo; desenvolvendo o conhecimento humano através das primeiras universidades ou pregando a paz social através de um sistema de obrigações dos mais poderosos em relação aos menos poderosos, e não apenas no sentido contrário. Na 
ciência, no trabalho, na educação, a Igreja seria a única responsável pelo verdadeiro sentido da palavra: "civilização".

Nem todas as obras de Leonel Franca mereceram a distinção de serem publicadas pela José Olympio. Mesmo assim, alguns de seus livros - como $O$ divórcio $^{186}$-- atingem um volume de vendas expressivo. Nele, Franca mantém a tese de que existe uma crise sistêmica da civilização social a partir da última metade do século XIX, mas dessa feita apresenta algumas nuances. A crise teria sido muito maior nos países que abraçaram a aprovação do divórcio, mesmo quando restrito a algumas exceções. (Estas logo seriam acrescidas de novas possibilidades, até que o divórcio se tornasse moeda corrente.) E que, portanto, se o Brasil aprovasse o divórcio, verdadeiras pragas sociais se abateriam sobre nosso país. Os efeitos incluiriam: diminuição no número de filhos, aumento no número de abortos e infanticídios.

A prova que Franca apresenta deste dado é de que os filhos dos divorciados seriam mais propensos a envolverem-se na criminalidade ainda crianças. Os países divorcistas também seriam aqueles com maior número de loucos, suicidas e com adultos mortos em idade precoce. Tudo isso, segundo Franca, seria explicável pela infelicidade que o casal encontra na falta de realização da vida matrimonial. As falhas na argumentação de Franca são evidentes ${ }^{187}$, como também o é sua habilidade para tentar trazer de volta um leitorado que não necessariamente se identifica com a causa. Esta preocupação é demonstrada pela disposição dos capítulos de modo a deixar por último a exposição dos motivos religiosos para não aprovar o divórcio - ocupando as últimas trinta e oito páginas, portanto depois de duzentas e cinquenta seis nas quais o tema não é tratado - e o uso das estatísticas e diversas citações retiradas de autores que não aparecem associados aos católicos.

O exemplo de Leonel Franca seria mais precioso para o grupo do que apenas como um formulador dos parâmetros a partir dos quais seria possível produzir filosofia, ou de afirmação da legitimidade do grupo diante do conjunto da sociedade. Monteiro

\footnotetext{
${ }^{186}$ FRANCA, Leonel. O divórcio. Rio de Janeiro: Agir, 1946. A $1^{\text {a }}$ edição data de 1931 e foi republicada sem alterações por sete vezes.

${ }^{187}$ Leonel Franca utiliza estatísticas da segunda metade do século XIX em diante, variando de país para outro de acordo com a data da de aprovação do divórcio. (Ou em alguns casos, de abolição de um direito ao divórcio recentemente obtido). O problema consistiu em isolar este fato de todos os outros condicionantes sociais - a industrialização, a urbanização, as péssimas condições de vida, etc. - e associar todos os mazelas sociais do período à aprovação do divórcio.
} 
Lobato escreveu uma resenha a Noções de História da Filosofia na qual elogia a erudição do manual, apesar de lamentar o "preconceito religioso do autor". Conclui que o "livro tem valor e cabe na estante do leitor mais intolerante" ${ }^{188}$. A crítica toca em um aspecto importante na definição de intelectual católico, confirmando-o como exemplo de que era possível produzir um tipo de pensamento legítimo socialmente e ao mesmo tempo marcado por uma opção religiosa.

O comentário de Lobato sobre Franca enseja uma reflexão sobre o modo como os exemplos de vida são construídos no interior deste grupo. Em virtude da justificativa para a existência do grupo consistir na atividade intelectual, os personagens escolhidos para servirem de exemplo ao grupo devem apresentar algum destaque neste âmbito. Entretanto, o critério não estava exclusivamente na excelência acadêmica, mas na demonstração a toda prova de submissão à Igreja e de defesa de seus interesses, em detrimento da tradição acadêmica estabelecida e até com o sacrifício do reconhecimento pelos pares. O comentário sobre Franca faz parte de uma série de exemplos, historicamente iniciados por $\mathrm{D}$. Vital, construídos com base na crítica à modernidade $\mathrm{e}$ ao seu projeto de ciência.

Este será o assunto explorado no próximo capítulo, que tratará do modo como os vitalistas reinventam o conceito de hagiografia e qual o papel desempenhado por elas no conjunto de sua obra. Ela define o tipo de atuação que o grupo espera de seus membros a partir da transformação de alguns personagens históricos em modelos a ser imitados.

${ }^{188}$ Revista do Brasil (39), março de 1919, pág. 354. Citado conforme: LOBATO, Monteiro. Críticas e outras Notas. 3 ed., São Paulo: Ed. Brasiliense, 1969, v. 18. (Obras Completas de Monteiro Lobato), pp. 69-71. 


\section{Capítulo V: As Hagiografias (e outros gêneros apologéticos)}

- Em resumo - disse Tarrou com simplicidade -, o que me interessa é saber como alguém pode tornar-se santo.

- Mas você não acredita em Deus.

- Justamente. Poder ser santo sem Deus é o único problema concreto que tenho hoje.

(Albert Camus, A Peste. 1947) 
O diálogo acima pertence ao romance A Peste, escrito por Albert Camus como uma alegoria da II Guerra Mundial e de seus efeitos sobre a cultura europeia. Ao inserir no diálogo entre Tarrou e Rieux, o protagonista e herói da história, a temática da santidade, Camus repisou uma temática comum na literatura da primeira metade do século XX. Vários são os escritores que abordam a questão da santidade em seus escritos, como é o caso de Ignazio Silone em Pão e Vinho (1936) e Graham Greene em O Poder e a Glória (1940), mas dissociando-a da Igreja Católica e seus símbolos (em A Peste, um dos personagens é um jesuíta, mas não é ele quem Camus escolhe para manifestar o desejo de ser santo). Existe portanto uma preocupação com formar um modelo de vida, mas ele rejeita o modelo tradicional da santidade.

No retorno da preocupação com a santidade está imbricado uma nova definição para ela, no diálogo com as necessidades do tempo moderno. A tarefa dos vitalistas era, portanto, trazer a literatura e as outras artes de volta para a preocupação com o religioso exigiria um diálogo com o estado da arte próprio à literatura no período, avesso a considerações de ordem religiosa. No caso brasileiro, por exemplo, a literatura evoluía no sentido do romance social, distante das preocupações intimistas e religiosas que poderiam pautar os autores franceses exemplares para os brasileiros: Mauriac, Julien Green e George Bernanos. Estes romancistas se ocupavam dos problemas da alma como os principais da condição humana, compreendendo a religião como um meio de dar resposta à falta de lógica do mundo.

O trecho do romance de Camus copiado acima mostra um eco de tais discussões: nele um personagem ainda busca por uma estética de vida, mesmo com o abandono da menção à transcendência como parte integrante. Ele é representativo de uma tendência em todo o Ocidente durante todo o século XX, observado por Lawrence Cunningham ${ }^{189}$. Este é um ponto de partida interessante para as obras que passamos a analisar, pois nelas é também possível perceber a discussão constante sobre qual o modelo de santidade possível no Brasil dos anos 1930, ou mais especificamente como construir modelos de comportamento capazes de seduzir leitores inicialmente desacostumados com as piedades tradicionais da Igreja.

Por outro lado, a aplicação da ideia de hagiografia é justificável na medida em que as produções do grupo se utilizam das convenções narrativas próprias à definição

${ }^{189}$ CUNNINGHAM, Lawrence. A Brief History of Saints. Massachussets: Blackwell, 2005. 
do gênero feita por estudiosos do discurso como Mikhail Bakhtin ${ }^{190}$ e Norma Discini ${ }^{191}$. Uma delas é a fusão entre o autor (narrador) e o herói (objeto da narrativa) apontada por Bakhtin:

\begin{abstract}
Esse gênero, em confluência com aqueles ditos da sabedoria popular como os provérbios, passa a não depender do jugo da assinatura autoral. Mas tal autoridade se confirma de modo próprio, enquanto a responsabilidade pelo ato de narrar acaba por ser diluída no terceiro, que é Deus. O querer-dizer da hagiografia se volta para um tom de seriedade aliada a uma verdade inabalável, enquanto o sujeito se afirma num corpo fixamente fechado e por meio de um acontecimento também fixamente fechado. (BAKHTIN, 1997, p. 198)
\end{abstract}

Os vitalistas mais jovens se inserem na produção de livros a partir da história de vida de outro personagem, o qual deve ser elevado à categoria de modelo tanto para si quanto para os demais vitalistas. Outro elemento presente nestes textos é a vontade divina como fator explicativo para a vida biografada. Quando Hamilton Nogueira se impõe o dever de explicar a conversão de Jackson de Figueiredo, ele recorre a uma "ânsia de fé" ou uma vontade de "libertar-se do ceticismo" que o leva a procurar a amizade de Farias Brito. E a amizade se torna o meio pelo qual age a graça que conduz Figueiredo à conversão, ainda que de modo inconsciente.

Este capítulo pretende demonstrar, portanto, que embora não haja nenhuma história de santo no sentido estrito do termo, há na produção textual dos vitalistas escritos de funções muito semelhantes a eles. Eles podem aparecer na forma de livros, artigos de jornal ou revista e resenhas. Tais escritos também forneceram modelos a serem imitados, reafirmaram a existência de uma dimensão sobrenatural, com a importante distinção de que esta se encontra no interior da História e não como algo à parte.

Os livros que se encaixam nessa tipologia foram publicados entre 1921 e 1944 e guardam semelhanças em suas estruturas, como por exemplo o uso recorrente a longas

190 BAKHTIN, Mikhail. A hagiografia. In: Estética da criação verbal. São Paulo: Martins Fontes, 1997, p. 198-200.

${ }^{191}$ DISCINI, Norma. Para o estilo de um gênero. Bakhtiniana, Rev. Estud. Discurso, v.7, n.2, p.75-94, 2012. Disponível em: http://www.producao.usp.br/handle/BDPI/40721cesso em: 17 abr. 2014. 
citações do biografado, interpolados por alguns comentários a tais citações. O título, neste gênero, é via de regra o nome do retratado, sem acréscimos ou subtítulos, indício de que o livro deveria atrair a atenção mais por seu objeto do que pelo autor ${ }^{192}$, o que não deixa de constituir o indício da tentativa de confundir narrador e biografado. Mesmo quando há dois livros sobre o mesmo personagem, como é o caso de Jackson de Figueiredo, os títulos se repetem.

Outra característica em comum a estas obras é apresentar ao mesmo tempo a obra e a trajetória de vida dos biografados e estabelecer uma espécie de onisciência na construção de sua trajetória de vida. É como se a vida fosse a grande obra de cada um destes autores e vivessem fosse o resultado da vontade própria, que neste caso equivale ao cumprimento de um mandato divino sobre estas vontades. Deste modo, a pouca repercussão dos escritos de Figueiredo na imprensa se tornam, na narrativa de Nogueira, um gesto abnegado em defesa do catolicismo. Ele poderia fazer sucesso se assim desejasse, mas abdicou disso em benefício de um bem maior (NOGUEIRA, 1928, P.64). Na narrativa de Jonathas Serrano, de modo semelhante, a falta de sucesso na carreira política de Júlio César Carneiro se tornasse uma das condições necessárias para a manifestação de seu chamado ao sacerdócio e à pregação.

ele se voltasse para a fé e se tornasse, assim, o padre Júlio Maria ${ }^{193}$.

Outro ponto em comum nas hagiografias é mostrar o desajuste do biografado em relação ao mundo exterior. Jackson, Júlio Maria e Farias Brito tentaram carreiras políticas, sem sucesso. Foram desvalorizados no mercado profissional antes de optarem pela defesa da fé católica ou da religião, de uma forma geral. Seus escritos fizeram sucesso dentro de nichos específicos, ao contrário da pretensão de seus autores, isto é, de ocupar o centro da arena do debate. Em compensação, este desajuste é vivenciado como uma antecipação de uma sociedade em mudanças. Seu trabalho, aparentemente sem sentido durante sua realização, seria a semente das transformações necessárias para recuperar o valor da religião no país, uma profecia de um novo tempo que o presente da biografia estaria realizando. Aos olhos do leitor contemporâneo, tais escolhas carregam a pecha de serem anacrônicas e teleológicas. Mas elas fazem sentido dentro do contexto

\footnotetext{
192 Outra marca constante dos livros que confirma esta ideia é a capa, a qual segue sempre o padrão de conferir mais destaque ao título (com letras maiores, no centro da página) do que ao autor, como uma informação a aparecer em um segundo plano.

${ }^{193}$ SERRANO, Jonathas. Júlio Maria. Rio de janeiro: Livraria Boa Imprensa, 1941, p. 47 e seguintes.
} 
em que são produzidas, e desse modo desvelam um elemento importante da cena cultura do período.

Outra teleologia típica das hagiografias consiste em explicar as adversidades enfrentadas por estes personagens como as condições para a manifestação de um bem maior. Exemplo disso é a abordagem feita por Serrano para explicar o episódio da morte da esposa de Júlio César Carneiro: a descoberta da fé como o resultado da dor, que bem pode ser da ausência de um ente querido ou da proximidade da própria morte. Este é o caso de Figueiredo, que encontra o momento decisivo para a conversão ao contrair uma gripe espanhola que quase matou diversos membros da família, inclusive ele próprio.

O modo como Amoroso Lima descreve sua experiência de conversão em "Adeus à disponibilidade" confere este sentido à dor, isto é, de condição prévia para a conversão. A presença das resenhas no estudo das hagiografias permite entender o modo como elas são enxergadas pelos outros membros do grupo e, dessa forma, confirmar quais são as características a serem retidas do biografado e do texto. Neste texto a vida do neoconverso não é vista em nenhum momento como prazerosa, mas o vazio da existência sem fé é tamanha que o único meio de escapar a ele é assumindo a fé religiosa.

Exemplo disso é o comentário de Jackson de Figueiredo presente em Literatura Reacionária acerca de Júlio Maria, de Jonathas Serrano. O livro é considerado uma conquista para o mundo das letras católicas brasileiras, tendo em vista a capacidade de seu autor de unir a paixão pelo objeto de pesquisa, com o rigor objetivo e a erudição na análise da documentação. Quanto ao biografado, sua importância para o catolicismo brasileiro do início do século XX pode ser resumida por seu pioneirismo em pensar as relações entre Igreja e Estado a partir da separação entres eles imposta pela Constituição de 1891.

Sua capacidade retórica lhe permitiu exercer um trabalho de difusão da fé católica de âmbito nacional, em uma época na qual os padres ainda demonstravam tibieza em propagar a fé católica fora do círculo restrito de fiéis. Júlio Maria, ao contrário, percorreu o país algumas vezes para fazer pregações a respeito deste e de outros temas, tais como a necessidade de uma cultura católica erudita e, por conseguinte, da formação de uma elite cultural católica. Ao fazê-lo deu início a uma linhagem retomada por Dom Sebastião Leme, algumas décadas depois. 
A primeira edição da biografia foi publicada em 1924, na editora do próprio Centro Dom Vital, e recebeu uma menção honrosa da Academia Brasileira de Letras. A segunda edição, ampliada, em 1941, saiu pela "Livraria da Boa Imprensa". Em termos editoriais foi possivelmente o mais bem sucedido. A análise interna da obra pode trazer elementos que ajudem a explicar o porquê deste sucesso.

A atuação política do então advogado e promotor público Júlio César Carneiro é comentada no primeiro capítulo do livro escrito por Serrano. Em sua curta vida política, ocorrida no final do Império, o promotor passou ao largo do abolicionismo e do republicanismo. É descrito como alguém próximo nas suas ideias ao partido conservador, mas que tentou se lançar candidato a deputado tanto pelos liberais quanto pelos conservadores, igualmente sem sucesso. A justificativa de Serrano para o fato de Júlio Maria não fazer parte dos abolicionistas era a de que ele era favorável a uma abolição lenta e gradual, que ficasse para as gerações seguintes. Vale dizer que era essa a opinião mais conservadora no cenário político.

Nesta breve descrição da vida de Júlio Maria já é possível perceber que ele e Farias Brito mantiveram uma postura semelhante na relação com o universo político e cultural do período que ajudam a justificar a escolha de Serrano em biografar os dois.

Ambos se tornaram bacharéis em Direito nas melhores faculdades do país (São Paulo para Júlio Maria e Recife para Farias Brito), mas não lograram converter este triunfo em boas posições na advocacia e na magistratura. No caso deste último, é possível discutir se o posto de professor do Colégio D. Pedro II não significou um sucesso razoável - ainda que se leve em conta a condição sui generis em que a vaga foi assumida, após a morte trágica de Euclides da Cunha. No caso de Júlio Maria, a reconversão é mais visível: de promotor público em cidadezinhas do interior de Minas ele passa a ser o principal orador da Igreja, tendo sido convidado a pregar sermões por todo o Brasil.

O fato de ambos não terem feito sua carreira como inicialmente planejado está relacionado à escolha em se dedicar à defesa da religião. De modo semelhante, os vitalistas são portadores de trajetórias prévias ou exteriores as quais, via de regra, não alcançaram o mesmo êxito dos investimentos no interior do Centro.

Serrano, por exemplo, possui diversas obras que poderiam ser classificadas como produção historiográfica, condensadas em uma matriz interpretativa do país. Formulado ao longo de toda a Primeira República, ele forja a identidade do Brasil na 
contramão de outras matrizes historiográficas consagradas durante a década de 1930. Identifica no catolicismo trazido pelo elemento branco o fator de civilização e de consolidação da identidade nacional, transformando a história pátria em um desfilar de exemplos edificantes de grandes homens em um trabalho progressivo de elevação moral dos cidadãos.

Dentro dessa perspectiva de História, o gênero biográfico assume a tarefa de fornecer os casos históricos que comprovem o tipo de História que Serrano pretendia construir. É significativo que tenha sido este o gênero utilizado por ele em sua progressiva aceitação no Instituto Histórico Geográfico Brasileiro. Em 1914, se apresentou ao Primeiro Congresso Nacional de História promovido por esta instituição com um estudo sobre Domingo José Martins, intitulado Um vulto de 1817. Após ser aceito como sócio, em 1919, sua produção no IHGB se acumula a partir de obras como O Precursor de Tiradentes (1920), em um estudo sobre Felipe dos Santos, e $O$ amigo do Imperador (1921), sobre Luis Pedreira do Couto Ferraz.

Outrossim, Serrano transformou as aulas do curso que oferecia às alunas da Escola Normal, destinada à formação das professoras do ensino básico em um livro, Metodologia da história na aula primária. Editado pela Francisco Alves em 1917, fez parte de uma série de manuais didáticos e de propostas para o currículo de História de sua autoria. Sua multiplicidade de atuações atraiu a atenção de diversos pesquisadores da área da educação e do ensino de História ${ }^{194}$. Destes trabalhos surge uma figura de

194 BARBOSA, Flávio André Rodrigues. O sanatório das almas: reação católica e radicalização política na década de 1930 no discurso de Jonathas Serrano. Rio de Janeiro: Universidade Federal Fluminense, 2011.

SILVA, Ana Paula Barcelos Ribeiro. Fidelino de Figueiredo e Jonathas Serrano: pensamento católico e radicalização política na década de 1930 - algumas reflexões. Passagens. Revista Internacional de História Política e Cultura Jurídica, Rio de Janeiro, v. 2 n.4, maio-ago. 2010, p. 39-66.

SILVA, Giovane José da. O Batismo de Clio: Jonathas Serrano e a historiografia católica na Primeira República. In:NICOLAZZI, Fernando, MOLLO, Helena; ARAUJO, Valdei (org.). Caderno de resumos \& Anais do $4^{\circ}$. Seminário Nacional de História da Historiografia: tempo presente \& usos do passado. Ouro Preto: EdUFOP, 2010.

ZANATTA, Regina Maria. Jonathas Serrano e a escola nova no Brasil: raízes católicas na corrente progressista. 2005. 205fls. Tese (Doutorado em Educação Filosofia da Educação) Faculdade de Educação, Universidade de São Paulo - USP, São Paulo, 2005. 
Serrano já nas décadas de 1900 e 1910 como um precursor do Centro Dom Vital em seu papel de mediador entre um ambiente intelectual hostil ao catolicismo e a defesa da religião romana, em um ambiente intelectual positivista.

Os livros didáticos de Serrano conheceram diversas edições entre as décadas de 1910 e 1950. Mais do que um confronto entre o positivismo e o catolicismo existe uma tentativa de combinar elementos destas duas matrizes de pensamento. Um exemplo é o tratamento conferido ao tema da herança europeia na construção do Brasil em seus manuais. O catolicismo, a cultura europeia e Portugal formam um conjunto homogêneo, vetor de transmissão da civilização para o país.

Em oposição a isso, a contribuição de indígenas e africanos para a História do Brasil é desprezada, não por motivos racialistas, mas pelo fato de estes dois povos não conhecerem o catolicismo. A única salvação (moral e cultural) seria a erradicação das crenças populares herdadas das culturas indígenas e africanas, em benefício da liturgia e da doutrina estritamente aprovadas por Roma. Aqui, romanização e civilização são sinônimos e pressupõem a condução autoritária de um líder.

Ele se anuncia como o defensor da fé e através dela mostra o caminho político a ser seguido, trazendo a luz da civilização para seu povo. No modo como Júlio Maria é descrito, os traços mais evidentes são os do intelectual e do apologista, embora o político também esteja presente pelo fato de ele ter enfrentado os problemas teóricos oriundos da separação entre Igreja e Estado e da vida no regime republicano de um modo que se tornaria exemplar para a instituição, como demonstram as seguintes passagens:

Júlio Maria teve a coragem de mostrar a necessidade de uma tríplice reação contra o positivismo prático: reação dos espíritos, reação da sociedade, reação dos governos.

E como fazer esta reação? Quais os meios, quais os instrumentos de que precisamos? E a resposta, desenvolvida em várias conferências, pode condensar-se nestas palavras: "A sociedade brasileira, ludibriada em tantas esperanças, vítimas de tantas desilusões... só pode reorganizar-se mediante uma reconstrução moral, que não podemos pedir senão à fé tradicional, aos costumes cristãos, à Religião Católica". (SERRANO, 1941, p. 229-230)

Afirmar que o país precisava de uma reconstrução moral em 1924 adquire um sentido especial, em consonância com os outros autores do grupo e suas propostas de resolver o problema de natureza política renegando a própria natureza desta atividade. A 
mensagem de Júlio Maria tinha o objetivo de atingir o topo da pirâmide social, embora se utilizasse da figura retórica do "povo brasileiro".

O papel de evangelizador das classes cultas é confirmado por diversas palestras, como a proferida em Juiz de Fora em 1897, com o objetivo declarado de levar "às suas classes letradas a convicção científica das verdades católicas tão mal compreendidas pela ignorância de uns, tão desnaturadas pela meia-ciência de outros." No Rio de Janeiro, no mesmo ano, o objetivo é trazer como a contribuição uma "doutrinação larga, elevada, judiciosa e serena da verdade católica nas suas relações com a sociedade” pois seria isto um "serviço para a pátria" 195 .

Julio Maria simbolizaria, portanto, a união entre fé e inteligência no combate aos inimigos da Igreja e da civilização brasileira. A primeira semente estaria lançada pelo exemplo, mas a messe precisava contar com a ação de novos filósofos e teólogos. Serrano afirma que nem Júlio Maria nem Farias Brito haviam deixado uma obra que fosse suficientemente sólida em termos de erudição ou profundidade de análise a ponto de dispensar o auxílio das gerações seguintes para completar a obra, abrindo espaço para a atuação das gerações futuras:

Cabe aos intelectuais a reação que Júlio Maria chamou a "revolução do pudor", usando da expressão de Lamartine para o movimento político francês de 1848. É oportuno reler o que, em 1909 pregava o eloquente orador da Catedral: "Eia, homens de letras! Eia, também, artistas! Iniciai no Brasil a revolução do pudor; que ninguém vos saia ao encontro com fórmulas vãs, romantismo ou realismo, na prosa, parnasianismo ou simbolismo; no verso; fórmulas vãs, repito. Só há duas literaturas: a literatura honesta e a literatura imoral. Contra esta, quanto antes, a vossa campanha, a qual será mais do que um troféu para vossos talentos; será um impulso à reconstrução cristã do Brasil (SERRANO, 1941, p. 118-9).

As múltiplas temporalidades presentes no trecho permitem identificar um traçado comum entre o presente de Serrano e múltiplos passados: o de Lamartine, em 1848, e o de Júlio Maria, em 1909. Se os três período possuem problemas em comum e a mesma solução, é porque a trajetória da humanidade se expressa através de um sentido ahistórico: a eterna luta entre a cultura religiosa e a cultura secular. Serrano se vê como

${ }^{195}$ Conferência de Assunção, $1^{\text {a }}$ Série, 1897, $1^{\text {a }}$ Conferência, p. 2. apud Serrano (1941, p. 126127). 
o elo mais recente desta luta, como um novo modelo de intelectual e não escolhe lado entre as escolas literárias; todas podem ser aceitas.

Em seu discurso a favor de um novo modelo de intelectual brasileiro Serrano faz eco à figura de Jackson de Figueiredo, que serve de guia para o grupo como o primeiro a ter aceito a tarefa imposta aos católicos por Júlio Maria. Figueiredo é objeto de diversas biografias, reforçando aspectos distintos de sua vida. Por exemplo, a biografia publicada por Hamilton Nogueira enfatiza temas como os destinos políticos do Brasil, os problemas sociais e outros relacionados à filosofia e à arte, nas quais Nogueira expõe sua própria opinião ou cita a de Jackson por longos trechos.

Por sua natureza, o livro é uma aposta de Nogueira para entrar no hall dos autores católicos consagrados. A escolha de Figueiredo como objeto ajudaria nesse sentido, embora ele também já tivesse merecido um livro de Perillo Gomes. Posteriormente, Tasso da Silveira também escreveria outra biografia. $\mathrm{O}$ dado de que os três autores de biografias de Figueiredo sejam membros do Centro Dom Vital é relevante na medida em que comprova sua importância na formatação dos temas e gêneros de interesse das pessoas que o freqüentaram.

A influência do Centro também ocorria no modo como estes autores analisam o biografado em graus distintos. Nogueira ressalta como a obra de Figueiredo conhece, depois da conversão, uma grande popularidade aqui e em outros países através das revistas católicas, como a francesa Études, na qual se publica uma resenha de seu livro sobre Pascal. Tamanho sucesso viria acompanhado da solução de seus problemas existenciais, pois antes da conversão Figueiredo seria uma figura perpassada por dilemas morais e filosóficos que comprometiam sua saúde e se coadunavam com a incerteza de sua vida profissional no Rio de Janeiro. Figueiredo encontraria remédio para esses problemas no círculo de amigos, especialmente Farias Brito.

A imagem é bastante distinta da produzida pelas páginas de A Ordem, na qual não havia espaços para concessões a dúvidas e medos interiores: Figueiredo é apresentado como um bloco monolítico, dotado de todas as características que fazem dele o líder da corrente católica e nenhum aspecto contraditório. Vários nomes são chamados a escrever textos curtos de apresentação de algum aspecto de sua vida, tais como "O Filósofo", "O Apologeta", "O Sociólogo" e assim por diante.

O volume se abre com alguns textos inéditos de Figueiredo. Há dois capítulos de uma obra que pretendia escrever sobre Joseph de Maistre e demonstraria como o 
problema da Revolução Francesa e a negação da tradição católica tinha sua origem no antropocentrismo renascentista. Ao primeiro raiar da noção de que as liberdades individuais deveriam ser superiores as de autoridade (da Igreja em primeiro lugar, e em seguida do Rei), todo o arcabouço que permitia uma boa sociedade estava em perigo. Este era um artigo que se pretendia de teoria política centrado exclusivamente em Joseph de Maistre, mas com algumas citações de Berdiaeff e Maritain. Todos os autores são mobilizados com o objetivo de demonstrar que a filosofia ocidental, de Descartes em diante, constituiu uma grande decadência.

A característica do "bloco monolítico" atribuída a Figueiredo é perceptível desde o primeiro artigo, uma biografia escrita por Olegário Silva. Este afirma que o jovem Figueiredo era perseguido por alguns professores e por isso tinha que mudar de colégio. No tempo de universidade, manteve um estilo de vida de fausto e envolvimento com brigas. Diante dessa parte espinhosa na vida de quem se pretende transformar em exemplo hagiográfico, Olegário Silva resolve o problema com o seguinte argumento: Figueiredo sempre havia sido admirado pelos colegas pela bravura e lealdade aos companheiros. Por estes motivos, sua coragem de praticar atos maus não seria fruto de uma natureza ruim, mas um desejo de viver intensamente, do qual resultou grande vantagem para a Igreja, depois que Figueiredo se converteu.

A ideia de um "santo moderno" é continuada pelos artigos seguintes, como o de Perillo Gomes, que o apresenta como um apologista cuja capacidade retórica era mais impressionante que suas ideias. O trecho, retirado da contribuição para o número especial de A Ordem, é exemplar:

Numa atmosfera assim constituída, uma personalidade forte e vigorosa adquire um alcance maravilhoso de projeção e realiza pelo seu poder pessoal o que não logram realizar os ordinários elementos intelectuais e morais de persuasão. Sua ação em favor de qualquer causa ou de qualquer ideia produz verdadeiros milagres na sociedade em que vive, nos espíritos sobre os quais emite os raios de sua simpatia e da sua influência.

Num meio como o nosso em que o preparo intelectual em matéria religiosa é deficientíssimo, tanto nos crentes como nos incréus, a eficácia do esforço apologético reside, sem a menor dúvida, na capacidade que tenha o expositor, o pregador, o argumentador, de exteriorizar o calor e a sinceridade das suas convicções ${ }^{196}$

196 GOMES, Perillo. O Apologeta. In: A ORDEM. Rio de Janeiro: Centro Dom Vital, ano VIII, n. especial, mar. 1929. 
Em um ambiente de pouco preparo intelectual dos católicos o calor e a sinceridade das convicções faria as vezes do esforço de argumentação para converter novos intelectuais a partir das ideias. As declarações de Gomes provocam estranheza pela sinceridade em admitir a falta de preparo não apenas do próprio Figueiredo mas de todos os intelectuais brasileiros do período. Elas também evidenciam os critérios de eleição para que o esforço intelectual seja avaliado como positivo pelo grupo do Centro. Isso ocorre quando a conversão dos ouvintes/leitores é alcançada. Nestes critérios, Figueiredo é um excelente "soldado da fé".

Alexandre Correia comenta o livro sobre Pascal e destaca como o francês logrou conciliar a fé e a alma moderna. Baseado nas Noções de Franca, estabelece uma linhagem entre Tobias Barreto, Farias Brito e Jackson de Figueiredo, construída com base na importância que a fé assume para estes três autores. O último seria portanto a realização plena da filosofia católica brasileira. Félix Contreras Rodrigues propicia ao leitor a análise mais densa do perfil de Figueiredo, enfatizando seu lado sociológico. Rodrigues considera-o um monarquista que interpretou a exortação de Leão XIII para que os católicos aceitassem a República francesa como se valesse também para o Brasil. Portanto, a discussão não deveria ser qual o melhor regime político para o país e sim como "recristianizá-lo", pois em todos eles os interesses católicos poderiam ser preservados.

Mas o que significaria a "recristianização" do regime? Em primeiro lugar, dar a devida importância à Igreja, centro da tradição brasileira. Para Figueiredo, as pátrias são criadas por desejo divino; no caso do Brasil, por exemplo, a religião esteve presente desde o início de sua formação história. A religião seria um dogma nacional, cujo desprezo condenaria qualquer regime instalado no país à decadência. Desse dogma nacional decorreriam as conseqüências que voltariam a formar a pauta de reivindicações nos anos 1930: a escola com ensino religioso, o casamento religioso com efeito civil e o privilégio da Igreja como a religião oficial do país.

Como em todos os outros gêneros, Amoroso Lima foi o autor entre os vitalistas que logrou explorar o gênero ao seu máximo. A obra de Alceu na qual o caráter hagiográfico fica mais evidente não está presente em obras dedicadas exclusivamente às memórias de personagens com quem ele viveu, em livros como Companheiros de 
Viagem (1971). As dificuldades para considerar este livro dentro da série de obras hagiográficas começa pelo fato de ela ter sido escrita na década de 1960, após sua abertura para os valores da modernidade e a estadia nos Estados Unidos, que alteram consideravelmente seu modo de pensar ${ }^{197}$. Além disso, nem todos os personagens descritos no livro têm a função de servirem como modelos de vida. Interpretando o título escolhido por Alceu, eles são companheiros, isto é, uma presença que a vida (viagem) permite compartilhar, da qual resta a lembrança sem que isso represente a escolha daquele personagem como modelo.

Outros motivos conduzem ao descarte de outra biografia de Tristão, sobre Afonso Arinos ${ }^{198}$. Diversas de suas características indicam ser este um livro de estreia, a começar pela escolha do objeto, um personagem bastante conhecido nas cenas literárias e bastante familiar ao próprio Alceu, como fica explícito no próprio livro. Sua escolha tem o mérito de diminuir o risco do empreendimento intelectual, e pode-se até dizer que sua parte mais importante consiste no prólogo, no qual Alceu afirma as bases de seu método de crítica literária, o expressionismo. Somando tudo isso ao fato de a publicação do livro preceder em seis anos à conversão de Alceu, e pode-se afirmar que esta obra não merece ser considerada de cunho hagiográfico.

Por outro lado, a coletânea de textos sobre Dom Leme é o exemplo por excelência deste gênero. Alguns aspectos da edição demonstram a importância atribuída pelos autores à celebração da memória do falecido. Além do fato de o livro ser publicado pela José Olympio, editora de renome, o cuidado na edição, presente no acréscimo de foto do cardeal, demonstra o grau de investimento na obra. A morte súbita do Cardeal, em certa medida inesperada e logo na sequência da fundação da Universidade Católica, o grande projeto de sua vida, são fatores que ajudam a explicar o clima favorável à publicação de um livro a seu respeito.

A escolha de Amoroso Lima como o autor chancelou a obra como oficiosa e deve ter levado em conta a proximidade entre as duas figuras, além da consagração de

197 A este respeito, ver: COSTA, Marcelo Timótheo. Um itinerário no século: mudança, disciplina e ação em Alceu Amoroso Lima. Rio de Janeiro/São Paulo: Ed. PUC-Rio/Loyola, 2006.

${ }^{198}$ Vale a pena esclarecer que, embora seja uma coleção de textos memorialísiticos sobre amigos e pessoas com quem Amoroso Lima conviveu, o livro Companheiros de Viagem foge aos objetivos desta tese por alguns motivos. O primeiro deles é pensar na data do livro: 1971, portanto bastante posterior ao nosso interesse. Além disso, nem todos os textos escritos nesta ocasião apresentavam como finalidade fazer o elogio do biografado, como foi o caso dos escolhidos para esta análise. 
Tristão e sua prodigalidade na publicação de livros. Em primeiro lugar, dos oito capítulos do livro, cinco já haviam sido escritos separadamente para cerimônias distintas de homenagem, no intervalo de um mês após o falecimento. Além da quantidade notável de cerimônias de homenagem, o local onde elas ocorreram também serve como medidor do status social do falecido: a Academia Brasileira de Letras, a Rádio Nacional, duas colunas publicadas em "O Jornal” e, como já era de se supor, uma coluna em “A Ordem” e uma reunião no Centro Dom Vital.

O livro conta com duas aprovações eclesiásticas, ambas de padres da própria cidade do Rio de Janeiro; é notável a ausência de textos de aprovação escritos por bispos de outras cidades. Em período bem mais tardio ao coberto por esta tese, Alceu contribuiria ainda para a elaboração de uma memória oficial do Cardeal ao escrever o prefácio da obra de Laurita Raja Gabaglia, homônima à sua e publicada pela mesma editora José Olympio, com a diferença de trinta e nove anos. Nos textos escritos no calor da morte do Cardeal, sobressai a figura do intelectual que ele poderia ter sido, mas que se sacrificou em benefício de um bem maior, da sua Igreja:

Como vivia para o apostolado do amor e do bem alheio, nunca se preocupou, nem jamais teve para isso tempo disponível, de pôr essa luminosa inteligência e essa memória angélica a serviço de uma obra de criação cultural. Fez mais. Foi além e acima da cultura, porque foi à própria vida, diretamente à vida. Os livros que escreveu foram escritos, antes de tudo, nas folhas das almas humanas. (LIMA, 1943, p. 57-58).

$\mathrm{Na}$ mesma vertente anti-intelectualista que emprega para fazer o elogio da figura do Cardeal, afirma que não é o livro que faz a cultura da pessoa, mas são as grandes personalidades que deixam sua marca nos livros. Quando sua ação de divulgação é tão evidente que eles não têm sequer tempo para escrever por si mesmos, os discípulos se encarregam de perpetuar a figura do mestre. A hagiografia de Dom Leme precisa lidar com o fato de classificar como intelectual alguém que colaborou enormemente para a cultura e as artes, mas não foi ele próprio um escritor. Apenas na juventude ele teria colaborado, sob o pseudônimo de Senex, em jornais de São Paulo, mas esse elemento não é tratado com maior profundidade.

Além do livro sobre o cardeal, Amoroso Lima proporciona aos leitores exemplos de textos hagiográficos como parte de diversas outras obras. Delas emergem dois modelos de ação intelectual, construídos a partir de personagens centrais em sua 
trajetória de conversão e liderança do laicato católico: o profeta (Jackson de Figueiredo) e o asceta (Leonel Franca). O modo como estas figuras são construídas pode compor o quadro de seu pensamento sobre a atividade intelectual, a começar por Jackson.

Ele se junta aos esforços para celebrar o nome de Figueiredo por diversas formas, inclusive pela resenha do livro de Hamilton Nogueira, redigida antes do afogamento, cuja publicação ocorre no exemplar de dezembro de 1928 de A Ordem. A menção a este texto é importante porque ele sinaliza que a apreciação de Alceu acerca de Figueiredo não se altera substancialmente com a morte deste. Pelo contrário, as ideias serão repetidas em duas crônicas escritas logo em seguida à morte e coligidas no segundo volume da terceira série de Estudos. Além dos três textos já mencionados, Alceu reserva um quarto texto, inédito, para o dossiê sobre Figueiredo publicado em $A$ Ordem. A quantidade de homenagens feita a Jackson não passou despercebida por Alceu, e seu comentário sobre a celebração em torno da imagem de Figueiredo é a seguinte:

\begin{abstract}
Numerosos ensaios sobre a sua personalidade têm aparecido da pena de Nestor Vitor, Xavier Marques, Tasso da Silveira, Agripino Grieco e até de estrangeiros, como do escritor argentino Roberto Paterson ou do publicista francês Auguste Viatte. Para que um moço de 37 anos, vindo do fundo esquecido de uma pequena província do norte conseguisse provocar o interesse de tantas penas diversas, era necessário que a sua personalidade fosse realmente excepcional. ${ }^{199}$
\end{abstract}

A descrição da personalidade de Figueiredo é feita em tom de admiração e se traduz em uma série de contradições, a começar por aquela que se prolongaria por toda a sua vida: Figueiredo passou a vida buscando encontrar uma causa pela qual se dedicar, mas quando a encontrava, não se fixava nesta e passava a procurar outro. Quando estancou o processo de busca encontrando conforto na religião e seus fundamentos transcendentais, esta o puxou de volta para a terra, como a exigir a identificação da presença divina em cada ser humano mais humilde, em cada detalhe ínfimo da natureza. Este é um aspecto central para compreender a trajetória do próprio Alceu e de seus colegas durante os anos 1930: a união entre o comprometimento político e uma opção religiosa, traduzida na luta pela realização deste compromisso com algumas causas de

${ }^{199}$ LIMA, Alceu Amoroso. Um realista: Estudos. Rio de Janeiro, A Ordem, 1930 (3ª Série $-2^{\circ}$ Volume). p. 255-6. 
crítica ao que havia de liberal na Primeira República e a propaganda de um modelo de organização social tida como a expressão das crenças religiosas.

$\mathrm{Na}$ resenha do livro de Nogueira, ele descreve a união entre o político e o religioso $^{200}$ em Jackson de Figueiredo como sendo os elos finais na cadeia de paradoxos que descrevem este personagem, intrinsecamente paradoxal. Figueiredo seria ao mesmo tempo um realista, na medida em que rebateu com ardor as fórmulas vazias de sentido da democracia liberal; mas também um idealista em sua dedicação sem limites às causas que abraça. Metodicamente doutrinário, em sua paixão por Pascal e por Tomás de Aquino, mas também um espírito em brasas: sua adesão à causa católica provem de um profundo convencimento.

Como é possível que Figueiredo fosse capaz de se realizar por meios tão distintos entre si como os propostos? A resposta a esta pergunta vem com o gran finale do texto que, recorde-se ainda uma vez, é o último escrito antes da morte trágica de Figueiredo:

E amando as estruturas rígidas, por excesso de amor ao caos. Clamando contra a liberdade, por excesso de liberalismo interior.

Ele é, assim, ao mesmo tempo, aquilo que geralmente se exclui. Individualista extremado, que combate ardentemente $o$ individualismo. Leitor apaixonado e que ao mesmo tempo tem horror ao teorismo seco e confinado dos bibliômanos, e vive seduzido pelo ar livre. (LIMA, 1930, p. 156).

O horror ao teorismo e a sedução do ar livre se traduzem por duas características inseparáveis na vida de Figueiredo: sua boemia e sua paixão pela política, que na impossibilidade de se traduzir em um partido católico, assumiu a figura da defesa de algumas bandeiras difusas e ainda assim marcadas por sua identidade religiosa. Nos textos seguintes, Alceu completa sua análise com o artigo publicado no número especial de $A$ Ordem, enxergando em Figueiredo a superação das três grandes correntes de pensamento do século XX: o materialismo, o ceticismo e o espiritualismo. O grande mérito do escritor sergipano consistiria em não esquecer os bons elementos existentes em cada uma destas correntes, de modo que elas se equilibrassem em suas características. O materialismo corrigiria a tendência ao subjetivismo própria do

\footnotetext{
${ }^{200} \mathrm{Na}$ qual residem ecos da querela de Charles Maurras e seu politique d'abord com Roma. Entretanto, a questão não é levantada por Amoroso Lima em nenhum momento de seu texto sobre Figueiredo.
} 
espiritualismo, que por sua vez impediria o lado cético de negar a possibilidade de sentido à vida. Por outro lado, o ceticismo também desempenhava uma importante tarefa: bloquear o risco de uma posição sectária.

A opção de retratar Figueiredo nesses termos enfrentava sua imagem estabelecida como um polêmico, fato reconhecido por Alceu quando escreve nas linhas logo abaixo do trecho citado: "muitos o consideram apenas um lutador, como ele aliás se considerava". Tristão julga esta imagem insuficiente para expressar toda a importância de um líder, visto que um soldado apenas cumpre ordens, sem saber quais são os grandes princípios estratégicos guiadores de seu Exército. O líder dos católicos deveria ser alguém com a capacidade de formular estes princípios, ou em linguagem bélica, de se revelar um general. Persistia neste caso, entretanto, uma dificuldade empírica: faltava a Figueiredo uma grande obra teórica. A justificativa encontrada foi a de que sua vida tinha sido muito curta para que ele conseguisse firmar uma obra neste campo.

A figura do teórico foi preenchida por Franca, cujo estilo de vista constituiu, na feliz expressão do imortal Cândido Mendes, a "disciplina da verdade" (MENDES, 1993). A ascese de França é o que lhe garante o tempo e a paz de espírito para auxiliar os demais a encontrarem seu caminho. Sua renúncia às glórias do mundo às quais sua inteligência faria jus foi a condição para que ele se consagrasse como o centro de gravidade do grupo. Eis como Tristão se manifesta na oração fúnebre do inaciano:

Cinquenta e cinco anos se passaram desde esse 7 de janeiro de 1893 , em que o senhor abria os olhos para o mundo e para uma vida de renúncias e sacrifícios prematuros a tudo o que, para a imensa maioria de seus contemporâneos, iria constituir o apego imediato e até por vezes a razão de ser de suas vidas. Ao homem que desde menino tudo sacrificou à glória divina, reservava o Pai Celestial a recompensa desta consagração. ${ }^{201}$

E prossegue na enumeração dos meios pelos quais a consagração se manifestou; no reconhecimento das inúmeras almas que Franca consolou com seus conselhos e sua direção espiritual; nas Faculdades que ajudou a criar e a reunir no grande sonho da Universidade Católica; nos Conselhos Nacionais dos quais participou - o de Educação, o do Livro Didático e o de Geografia. Entre amigos e discípulos, não sobravam dúvidas das qualidades demonstradas por Franca.

${ }^{201}$ PADRE Leonel Franca, Jornal do Brasil, 05 de set. 1948, p. 8. 
A consagração final de Leonel Franca vem do grosso volume escrito pelo padre D’Elboux em sua homenagem, um lustro passado de sua morte ${ }^{202}$. Em texto de minha autoria previamente publicado ${ }^{203}$, já desenvolvi a hipótese de que a trajetória de Leonel Franca se explica em grande medida por uma dupla determinação: por um lado, sua formação intelectual de qualidade acima do convencional e coroada de reconhecimento por seus méritos no Brasil e em Roma e a saúde frágil, a preservá-lo do desgaste de atividades administrativas que pudessem provocar uma nova crise de endocardite. ${ }^{204}$

Neste capítulo, demonstrou-se como os modelos de vida construídos entre os vitalistas incluíam a intervenção na cena pública nacional como parte necessária. Assim como na França dos anos 1940 de Philippe Ariès ${ }^{205}$, a política se tornou no Brasil dos anos 1920 um assunto do cotidiano, incontornável pelas consequências práticas nas quais acarretava uma mudança de regime ou de comandante. Em tempos atribulados como os que se vivia, não era permitido aos santos serem eremitas; por outro lado, era necessário preservar a Igreja das disputas partidárias que maculavam a vida eleitoral do ocaso da Primeira República. No capítulo seguinte, será a vez de tratar de como se deu a resposta ao desafio de unir religião e política sem comprometer exageradamente a Igreja com nenhum dos atores, mas abrindo espaço para sua atuação.

\footnotetext{
${ }^{202}$ Trata-se da obra que ainda permanece como uma das principais fontes de informações a seu respeito:

D’ELBOUX, Luiz Gonzaga da Silveira. O Padre Leonel Franca. Rio de Janeiro: Agir, 1953.
}

203 ARDUINI, Guilherme Ramalho. Padre Leonel Franca, SJ: o centro de gravidade da sociabilidade católica carioca (1918-1948). In: RODRIGUES, Cândido; ZANOTTO, Gizele (Org.). Catolicismos e sociabilidade intelectual no Brasil e na Argentina. Cuiabá: EdUFMT, 2013, p. 31-54.

\footnotetext{
${ }^{204} \mathrm{O}$ endocárdio é uma membrana do coração que permanece em contato direto com o sangue, auxiliando na função do coração de bombeá-lo para o resto do organismo. A endocardite é o nome médico para o mau funcionamento desta parte do organismo e, por se tratar de uma região de difícil acesso para intervenções cirúrgicas ou para a ação de substâncias medicamentosas, consiste em uma doença que dificilmente pode ser curada por completo.

205 "As gerações que chegaram aos vinte anos de 1940 para a frente já não tiveram consciência da autonomia de sua vida privada. Quase não havia momento do dia que não dependesse de uma decisão política ou de uma "agitação pública". Retirado de:
}

ARIÈS, Phillipe. O Tempo da História. Rio de Janeiro: Francisco Alves, 1989. 


\section{Capítulo VI: Os escritos sobre política}

É certo que, no nosso grau de civilização, ainda subsiste o predomínio dos indivíduos sobre as instituições. Reforçar a estrutura política e elevar o grau de educação individual, baseada no conhecimento mais profundo de nossas condições peculiares, são condições primordiais de nossa evolução, como povo cuja consciência coletiva ainda é tão débil.

(Alceu Amoroso Lima, 1923) 
Na epígrafe, Tristão apresenta de forma concisa e clara os desafios e as respostas defendidas por ele para a situação política do país, e que serão objeto deste capítulo. A epígrafe faz parte de uma resenha de um "precioso estudo" de Oliveira Vianna, nas palavras de Tristão de Athayde: os Pequenos Estudos de Psicologia Social (1923). O livro é elogiado em sua proposta de reforma política, que retira poder da esfera municipal e fortalece o poder central, com o objetivo de destruir a cultura política dos clãs, tão arraigada no território nacional.

Era vista como positiva a opção de Vianna em se pautar por uma análise da situação política a partir de evidências empíricas, sem prender-se a princípios teóricos abstratos distantes da realidade. Tristão reproduziu com aprovação a linha divisória estabelecida por Oliveira Vianna entre o idealismo utópico dos liberais e o idealismo orgânico dos conservadores. Os exemplos originados da Europa e da América do Norte não poderiam ser aplicados na realidade brasileira, sob risco de dilacerar o país. Ele esperava que a República aprendesse com o exemplo do Império, com suas trocas pacíficas de gabinetes e o equilíbrio a evitar os extremos, marca registrada da administração econômica e política da nação.

Posto que as necessidades do país serviam de guia para as decisões, o bom senso imperava e não havia incômodo em um gabinete conservador realizar reformas liberais ou então que medidas para assegurar a centralidade do poder e a unidade do país fossem tomadas por um governo liberal, como o de Diogo Feijó. O contrário disso seria o que se passava na República, pródiga em exemplos de partidarismo cego. Além das virtudes políticas do livro, Alceu vislumbrava no estudo de Vianna, especialmente no uso dos dados empíricos para sugerir alternativas políticas concretas, um passo importante na direção de uma sociologia mais científica.

Publicado em 1923, a opinião de Alceu condensa alguns traços dos temas desenvolvidos ao longo da década e demonstram como também na reflexão concernente à política a análise proposta por Tristão vai gradativamente convergindo com a dos vitalistas. A crítica ao regime liberal e o fortalecimento do poder central são temas dos escritos políticos do grupo ao longo tanto da década de 1920 quanto da de 1930. A ligação entre política e religião já havia chamado a atenção de estudiosos como Gustavo 
Sorá ${ }^{206}$, para quem a crítica ao regime liberal da última década da República Velha é a própria razão da existência do Centro. Seria lícito se perguntar, entretanto, se os dois não expressam uma mesma realidade para os vitalistas, isto é, se eles não traduzem o religioso pelo político. Tais questionamentos nos remetem à percepção que os próprios membros do Centro fizeram a respeito das relações entre religião e política. A ideia básica foi apresentada acima; cabe ainda, entretanto, uma análise mais detida sobre a descrição de Jackson feita por Tristão.

Em seus primeiros escritos no Rio de Janeiro, Jackson de Figueiredo demonstrou preocupação com a instabilidade inerente à mudança de Regime e de códigos sociais de conduta. A Abolição e a instalação da República embaralharam as divisões sociais e tornaram difícil entender que é quem nesta nova ordem, criando um vazio dentro do qual não haveria limites para as ambições de transformar o que é público em fonte de benefícios pessoais. Em 1910, fez um comentário irônico ao hábito ou o ato de "cavar" - na gíria da época -- um emprego publico, isto é, de usar a rede de contatos e favores pessoais para obter uma posição bem remunerada:

\begin{abstract}
Ninguém que se preza cava a miséria de 1000 réis; a cavação visa sempre boladas de contos, coisa que dê, pelo menos, para uma viagem à Europa ou a compra de uma casa. O mordedor antigo tinha qualquer coisa de humilde e comovedor. Os cavadores de hoje têm um curso completo de elegâncias e refinamentos maneirosos que os fazem parecer donos do mundo e de toda a gente que os cerca. ${ }^{207}$
\end{abstract}

Os "mordedores antigos" eram "comovedores" porque sabiam respeitar a velha ordem imperial e escravocrata; eram submissos, esperando que dessa atitude é que resultaria alguma possibilidade de ascensão, de acordo com a sorte de encontrar um protetor poderoso e generoso. Em tempo de república pós-abolição, o espectro da mudança precisava ser alimentado através de uma nova postura de inserção social. As modas europeias eram deglutidas sem moderações e servem para expressar um pretenso

\footnotetext{
206 "Mais do que por uma intenção doutrinário-religiosa, esse grupo era unido por uma rejeição visceral à República Velha, e à intenção de introduzir o "social" na produção intelectual." Retirado de:

SORÁ, Gustavo. Brasilianas: José Olympio e a gênese do mercado editorial brasileiro. São Paulo: Edusp, 2010, p. 123.

${ }^{207}$ FIGUEIREDO, Jackson de. Cavação, Revista Fon-Fon, 22 jan. 1910. Retirado de:

SEVCENKO, Nicolau. Literatura como missão: tensões sociais e criação cultural na Primeira República. São Paulo: Companhia das Letras, 2003, p. 57.
} 
cosmopolitismo que justifique o privilégio de ser tratado como mais iguais que os outros em um regime onde todos deveriam ser cidadãos.

Mas diferentemente de chá dos cinco (outra moda europeia rapidamente copiada na capital federal) a "civilização" não pode ser sorvida de modo rápido e indolor. Tentar copiar os valores civilizados para uma República nos trópicos sem questionar as práticas patrimonialistas tradicionais é aceitar cair no ridículo e no desconforto de situações grotescas. Em outras palavras, o mal estar de Figueiredo dá ensejo a perceber, ao mesmo tempo, a capacidade dos intelectuais em perceber um problema e a dificuldade enfrenta-lo.

Sevcenko demonstra através dos artigos da imprensa que o mal-estar dos escritores do período é o mesmo de Figueiredo. Neste mundo de aparências, os códigos de ética se diluem e os sujeitos se movimentam de acordo exclusivamente com seus interesses pessoais. Era necessário, portanto, restabelecer o primado da ordem na vida pública e o da ética na vida pessoal. A diferença principal de Figueiredo com os outros autores é que por ele o guia supremo neste restabelecimento seria a Igreja, com seu repertório de valores que já haviam conduzido a nação desde a chegada dos portugueses até o final do Império (o que, não por acaso, coincidia com o início do período de crise política crônica).

Se esta linha de raciocínio ganha a simpatia de outros autores durante a crise política da década de 1920, suas raízes estão no modo como se deu a transição entre o Império e a República, em um processo eivado das contradições: um Império em longo processo de declínio, cujas estruturas sociais se prolongam pelas décadas seguintes, encontra "uma República que não foi", nas palavras de um de seus principais intérpretes ${ }^{208}$.

A formação do Estado Republicano reproduziu e ampliou vícios do tempo do Império, como aquele comentado por Jackson de Figueiredo. Ao mesmo tempo em que se desenrolou a busca desenfreada pelo lucro, consolidam-se as divisões sociais e espaciais das grandes cidades a partir de critérios racializantes. Lilia Schwarcz ${ }^{209}$ identifica aí um retrocesso na condição social de importante parcela da população. Se

${ }^{208}$ CARVALHO, José Murilo. Os bestializados: a República que não foi. São Paulo: Companhia das Letras, 1987.

${ }^{209}$ SCHWARCZ, Lilia Moritz. Introdução: As Marcas do Período. In: SCHWARCZ, Lilia Moritz. A Abertura para o Mundo (1889-1930). Rio de Janeiro: Objetiva, v. 3, p. 19-342012. (Coleção História do Brasil Nação: 1808-2010) 
durante o Império havia para os afrodescendentes sempre a possibilidade de ser considerado um "alforriado" ou um "liberto", na nova ordem republicana tal possibilidade inexistia, posto que sua condição socialmente inferiorizada se dava por critérios inscritos na própria cor da pele, no fenótipo e nas expressões culturais mais integradas no dia-a-dia da população, como o batuque e a capoeira.

Nesse jogo de forças, a manifestação de uma religiosidade católica em sintonia com os valores do Vaticano - isto é, romanizadora - adquirem um caráter ambíguo quando relacionados ao tema do progresso e da civilização. Por um lado, eles representam um passo em direção à civilização quando confrontados às manifestações de origem africana. Por outro lado, são vistos como um retrocesso pelos "livrespensadores" ligados ao positivismo e ao cientificismo. Os escritos dos vitalistas demonstram sua participação neste embate, do lado é claro dos que desejam enxergar no catolicismo romanizador o progresso, com toda sua carga de exclusão das manifestações populares.

José Murilo de Carvalho traduz o que significa esta nova ordem em termos de cidadania: a exclusão da participação na vida pública oficial do país é rebatida com a formação de outros espaços de sociabilidade. Elas seriam as "comunidades dentro da comunidade", isto é, os espaços de formação de solidariedade no interior de uma cidade estruturalmente hostil à sua presença. Depois de um longo processo de resistência e negociação. Algumas delas seriam incorporadas à paisagem urbana, adentrando o panteão informal de "símbolos nacionais", como foi o caso da roda de samba ou de capoeira, ou o campo de futebol. Outras, como as festas populares, seriam substituídas por manifestações em conformidade com os ditames da Igreja.

O enfrentamento entre as culturas populares e seus adversários se materializam na questão do uso do espaço público. Um dos principais atores do embate é, portanto, a cidade em seu momento de conclusão do período de "regeneração", como foram chamadas por Nicolau Sevcenko as reformas urbanas que modificaram completamente a paisagem urbana do Rio de Janeiro. Este autor realça a condição materialmente excepcional do Rio de Janeiro nas primeiras décadas da República: ela possuía o décimo quinto porto mais importante do mundo, além de uma importante malha ferroviária capaz de conectá-la a toda a crescente área produtiva para agroexportação, isto é, do sul de Goiás ao Rio Grande do Sul, além de uma rede de navegação de cabotagem. Abrigava o centro financeiro do país, as burocracias federais e a maior 
população urbana do país, cuja maioria trabalhava dias e noites em um parque industrial em constante crescimento.

A condição econômica excepcional deu ensejo à formação de uma casta de arrivistas e especuladores que viviam das oportunidades de negócios faraônicos de uma economia e uma sociedade em crescente expansão, mas pouco regulada. Ao artificialismo da situação econômica parecia se estabelecer um paralelo no estilo de vida, dando possibilidade ao surgimento de um tipo social marcante na paisagem carioca do início do século XX: o janota, smart ou chic.

Os três termos provem de línguas distintas mas expressam um mesmo personagem. Sempre elegante, frenético frequentador de bares e cafés da paisagem carioca em ritmo intenso de transformação, ele é ao mesmo tempo o leitor e o objeto das crônicas sociais, em sua tentativa de estabelecer algum princípio de ordem e hierarquia dentro de uma sociedade na qual os valores sociais escravocratas se mantinham atuantes, apesar da Abolição. Os cronistas sociais, como Figueiredo Pimentel do Gazeta de Notícias, eram içados à condição de intérpretes de uma sociedade carregada de contradições em suas constantes transformações:

A crônica social teria uma importância básica nesse período de riquezas movediças. Era a tentativa de dar uma ordem, pelo menos aparente, ao caos de arrivismos e aventureirismos, fixando posições, impondo barreiras, definindo limites e distribuindo tão parcimoniosamente quanto possível as glórias. Ela concorre para frear ou legitimar, pela hierarquia do pecúlio, o frenesi de "aristocratizações" ex abrupto que brotam como cogumelos pela sociedade republicana adentro. (SEVCENKO, 2003, p. 54).

O Brasil, metonimicamente expresso no Rio de Janeiro, professava sua fé nas instituições liberais sem querer abrir mão dos privilégios característicos do período colonial e do Império. O paradoxo foi condensado pela fórmula da "República aristocrática", nos dizeres de Lima Barreto. É nesse contexto que floresceriam as experiências de crítica aberta ao liberalismo, tão marcantes da década de 1920, das quais tomaram parte os escritores do Centro, a começar por Jackson de Figueiredo. A identificação de Figueiredo com a causa católica é a sequência final de uma série de adoções de movimentos nacionalistas e participações em periódicos.

Estas experiências prévias possuem algumas características em comum: existiram durante pouco tempo e tiveram baixa repercussão, mas serviram de laboratório para a formulação de um discurso com ênfase no civismo social, e na 
proposta de uma educação que servisse de instrumento para a reprodução dos valores patrióticos. Antes de fundar o Centro D. Vital, Figueiredo engajou-se em movimentos que pugnavam pela expansão da rede de ensino a fim de alcançar a todos os cidadãos com uma proposta curricular que valorizasse o ensino religioso e a obediência à ordem constituída.

A primeira iniciativa da qual Figueiredo participou foi a revista Brazilea, fundada em 1917 por Álvaro Bomilcar e Arnaldo Damasceno. A revista elege um tom antilusitano como sua marca principal, e faz da restrição aos portugueses de certas atividades econômicas (notadamente o comércio e da imprensa) sua maior bandeira. Pugnar pela expulsão dos portugueses da imprensa era uma decisão estratégica na medida em que algumas das principais livrarias estavam nas mãos desta colônia, também responsável por boa parte da impressão dos livros vendidos no Brasil. A opinião de Figueiredo sobre a falta de brasileiros nas ocupações estratégicas coincidiu com sua decisão de fundar uma livraria própria em 1921.

A militância pela causa antilusitana continuou nas páginas da revista Gil Blas e da Ação Social Nacionalista, movimento fundado por Álvaro Bomílcar e Arnaldo Damasceno em 1920 na continuação das ideias de Braszilea, com a inclusão de um tom crescentemente autoritário como a melhor alternativa para enfrentar a crise do país. A defesa da volta do catolicismo ao status de religião oficial do país recebe seu impulso e sentido neste contexto ${ }^{210}$.

As experiências iniciais de Figueiredo foram recolhidas em livros como Do nacionalismo na hora presente ${ }^{211}$, que busca acertar as contas com sua participação no movimento da Ação Social Nacionalista. Pelo teor de algumas de suas passagens, é possível supor que Figueiredo faz dele uma ferramenta para tomar a liderança do movimento e encaminhá-lo para uma finalidade específica.

A conclusão do livro apontava para a necessidade de exigir dos brasileiros uma postura mais firme contra os privilégios que a colônia portuguesa possuía em nosso meio. Ao mesmo tempo em que procurava dar esta vertente política ao movimento e pontuar objetivos mais concretos, Figueiredo tecia críticas ao processo formador da

${ }^{210}$ A esse respeito, conferir:

NOFUENTES, Vanessa Carvalho. Estratégias de mobilização da pátria: as ligas como lugar de mobilização social durante a Primeira República, Cadernos de História, v. 8, ano 4, n. 2, dezembro de 2009, p. 54-67.

${ }^{211}$ FIGUEIREDO, Jackson. Do nacionalismo na hora presente. Rio de Janeiro: Livraria Católica, 1921. 
Ação Social Nacionalista tendo em vista a falta de unidade interna, da qual a causa ficava comprometida. O objetivo do movimento não deveria ser expulsar os portugueses do Brasil mas expô-los às mesmas condições de vida dos outros estrangeiros residentes no país. Com tal objetivo em mente, era preciso controlar os grupos mais radicais dentro da Ação Social Nacionalista e impedir que eles se transformassem em um grupo de perseguição.

Figueiredo também comenta os escritos de Álvaro Bomilcar, demonstrando uma uma postura ambígua em relação a seu parceiro de Brazilea, na qual existe um misto de vontade de se aliança com Bomilcar e competição pela liderança do movimento nacionalista. Ao mesmo tempo em que se diz de acordo com o que ele pensa em termos de nacionalismo e patriotismo, lamenta a falta de ideias novas em seus escritos, que reproduzem o que já havia sido dito na revista.

A religião aparece de roldão no interior da argumentação de Figueiredo neste primeiro livro, como um elemento reforçador do nacionalismo, sentimento inerente à vida em sociedade. A crença sustentada pela religião católica de que todos os seres humanos são iguais perante Deus não guardaria, segundo Figueiredo, nenhuma contradição com o sentimento nacionalista. Seria possível até manter uma postura de amizade com os portugueses na base da herança comum entre os dois povos, na qual está evidentemente incluído o catolicismo.

Em Do Nacionalismo..., Jackson preocupou-se em recusar a todo custo os radicalismos e demonstrar as intenções pacíficas, de sua visão política. Bem mais agressiva seria a visão imposta no livro Reação do Bom Senso ${ }^{212}$, coletânea de artigos publicados em O Jornal, na maioria sobre a eleição presidencial de 1922, em defesa da candidatura de Bernardes e no ataque a Nilo Peçanha. Alceu fez o elogio do livro, qualificando-o como uma "campanha de imprensa, corajosa, inteligente, desinteressada e leal como sempre, que foi talvez o elemento moral mais poderoso da candidatura Bernardes, colocada aqui entre o ataque desbragado da oposição e a justa suspeição oposta à sua imprensa",213.

A observação de Tristão permite afirmar que ele aceita como válida a transformação do embate político em moral, relacionando a defesa de seu ponto de vista

\footnotetext{
${ }^{212}$ FIGUEIREDO, Jackson. Reação do bom senso. Contra o demagogismo e a anarquia militar: artigos publicados "n'O Jornal" do Rio de Janeiro (1921-1922). Rio de Janeiro: Annuario do Brasil, 1922.

${ }^{213}$ Estudos 1923, p. 784.
} 
com uma questão de convicção, não de interesse, ainda que aquela tenha sido contrariada pela prática de governo de Bernardes - com a qual, vale ressaltar, Alceu não concordava, conforme deixou explícito em seu comentário final ao livro, dizendo que se Jackson pudesse avaliar o título que escolheu para sua obra à luz das realizações de Bernardes, se arrependeria dele. No exíguo comentário, Tristão ainda encontra espaço para chamar Joseph de Maistre de "genial contrarrevolucionário".

O quadro traçado nos escritos de Jackson durante a campanha é de um país à beira do caos por ação de alguns desordeiros no Exército, inspirados por teses "positivóides". Por este termo, Figueiredo pretende diferenciar os verdadeiros positivistas, para os quais reservava o respeito, dos que interpretavam de forma equivocada os preceitos de uma crença que teria tudo para ser conservadora. O "bom" positivismo seria, portanto, aquele que reforça o caráter centralista do poder, o apego a uma disciplina e a uma hierarquia sociais. O contrário disso faziam os militares revoltosos. Ao longo das obras, há mudanças e continuidade de Figueiredo em relação ao positivismo. Do apego à teoria expresso em Do Nacionalismo (1916) ao livro Reação (1923), a crença nas três fases dá lugar à fé católica, mas a visão política autoritária se mantinha.

Outros alvos da crítica são: Nilo Peçanha (opositor de Artur Bernardes na eleição de 1922), Edmundo Bittencourt (dono do Correio da Manhã jornal que apoiou Peçanha) e Oldemar Lacerda, um dos inventores das cartas atribuídas a Artur Bernardes. Além dos militares, oligarquias descontentes com o status quo- como era o caso da Bahia, Rio Grande do Sul e Rio de Janeiro -- apoiaram a campanha de Nilo Peçanha. A campanha inovou ao fazer comícios populares para tentar angariar um número maior de adeptos.

Este último elemento é o que mais irrita Jackson, pois em sua avaliação quanto maior a participação do povo na política, maior a chance de ela derivar em caos. $\mathrm{O}$ modo como Jackson enxerga a democracia popular é distinto de sua compreensão do que fosse o regime republicano. Este não é condenado; seus erros são os mesmos do Império, tais como a Igreja subjugada ao poder civil e a maçonaria/liberalismo contaminando a cultura nacional. A diferença era a de que o chefe do Império era o primeiro a tentar diminuir a importância e o papel da Igreja, enquanto a República ainda tivera sua chance de se recuperar. Toda a aposta residiria nas lideranças escolhidas para governar o país, e a eleição de Bernardes seria um passo na direção correta. 
Por isso as críticas também se endereçavam aos principais apoiadores da Reação Republicana, como é o caso de José Joaquim Seabra (presidente da Bahia e vice na chapa de Nilo Peçanha) e de Borges de Medeiros (presidente do Rio Grande do Sul, apoiou Nilo Peçanha). Não é possível avaliar o impacto dos artigos de Figueiredo. Se por um lado a transformação deles em livro é um indicativo de seu sucesso, por outro a interrupção de sua colaboração em O Jornal, a partir de uma "Nota Final" reproduzida no livro que não explica muito bem o porquê do final da colaboração no jornal dá ensejo a pensar do que algo se passou. Ela apenas afirma que a revolução estava derrotada depois do levante de julho de 1922, rapidamente sufocado por Epitácio Pessoa.

Ao mesmo tempo em que o livro permite enxergar um Figueiredo totalmente imerso nas disputas políticas nacionais, os nomes de Joseph de Maistre e De Bonald são constantemente citados, além de Santo Tomás de Aquino, principal referência para argumentar que a obrigação de todos os descontentes era resistir aos desmandos dentro da legalidade, sem contestar a ordem estabelecida. As raízes filosóficas do seu antiliberalismo foram estudadas por Christiane Jalles de Paula ${ }^{214}$, nele enxergando uma ideia de liberdade construída no contraponto ao livre-arbítrio individual, e calcado na noção de obediência - à autoridade constituída, à tradição cultural do país e, em última instância, à Igreja, fiel representante da Autoridade suprema, divina, sobre a terra.

Deste ponto de vista, existe uma aguda ligação entre a leitura de Figueiredo sobre a realidade, a defesa intransigente do bernardismo e a concessão de um novo espaço para a atuação do leigo na Igreja brasileira. Para regressar ao estado de harmonia social era preciso que a Igreja voltasse a impor sua centralidade no campo social. Para que isso ocorresse, por sua vez, era necessário contar com líderes políticos atuantes no reconhecimento da Igreja - como era o caso de Bernardes - e um exército de formadores de opinião para preencher os espaços estratégicos na mídia para a propaganda deste projeto. Estes escritos fizeram escola entre os membros do Centro e deixaram discípulos, a amplificar suas críticas ao regime liberal. Um deles foi Perillo Gomes, em O Liberalismo ${ }^{215}$.

A edição do livro a expensas do autor, fora do país, é um indício de sua posição de outsider no cenário intelectual. O tom panfletário do escrito e o uso constante de

${ }^{214}$ PAULA, Christianne Jalles de. "Jackson de Figueiredo e a questão da liberdade" EM: RODRIGUES, Cândido Moreira \& PAULA, Christiane Jalles de. Intelectuais e militância católica no Brasil. Cuiabá: Editora UFMT, 2012, pp. 75-95.

${ }^{215}$ GOMES, Perillo. O liberalismo. Barcelona: Imprenta Boada, 1933. 
clichês como a associação entre o liberalismo e a maçonaria ajudam a localizar a obra em um tipo de produção distante das mais apreciadas pelos críticos. Os outros livros publicados por Perillo Gomes neste período ${ }^{216}$ também pertenciam a estas classes: a defesa da ortodoxia católica, o gênero biográfico e o combate aos "inimigos da fé". $O$ Liberalismo se divide na análise desta ideologia em seus aspectos político, econômico e cultural, por exemplo, no que diz respeito à defesa do ensino leigo e das liberdades individuais.

Depois de atacar cada uma dessas facetas, Perillo Gomes enfrenta aquele que considera o mais nocivo: o liberalismo católico, que deseja conciliar a vida da Igreja com a preponderância do mundo secular. Gomes considera essa hipótese absurda, pois a coincidência seria total entre o liberalismo e a maçonaria, principal inimiga da Igreja. A identidade entre os dois nasce da defesa que ambos fazem do direito ao livrepensamento e à liberdade de expressão individual. Portanto, um católico liberal seria alguém capaz de atacar a própria crença que afirma professar.

Os últimos capítulos do livro se dedicam à "análise de casos práticos" de liberalismo na Itália, na Alemanha ou mesmo no Império brasileiro - no caso deste último, com uma atenção especial aos historiadores sobre o período. Um deles é de Azevedo Amaral, a quem Perillo Gomes concede o elogio de reconhecer sua erudição. Mesmo assim, discorda de seus argumentos em favor do Império como um regime de profunda liberdade de opinião e, portanto, um período benéfico ao país. O argumento de Perillo Gomes é que o resultado da liberdade que D. Pedro II concedeu aos súditos foi terminar seus dias deposto e exilado; mais do que isso, relembra o caso da questão religiosa para afirmar que o Império não foi o período de maior liberdade que existiu. A conclusão de Gomes é semelhante à de Figueiredo: a justa liberdade consistiria na obediência à autoridade.

Gomes reputa ao comportamento das "classes ricas e poderosas" o agravamento da crise social, pois são elas que precisam voltar a acreditar em determinados valores cristãos. Haveria uma necessidade prática de fortalecer a ideia de que todos os seres humanos são iguais perante Deus e que após a morte todos serão julgados conforme

${ }^{216}$ O primeiro, Penso e Creio (1921) foi o único a alcançar duas edições. Depois disso vieram: Ensaios de Crítica Doutrinária (1923), A Teosofia (1924), Polêmica e Doutrina (1925), O laicismo (1926), Jackson de Figueiredo (1926) e D. Vital (1932).

As informações sobre a vida deste autor se dão na mesma proporção do sucesso de suas obras. Apenas o Diccionário bio-bibliographico brasileiro de diplomacia, política externa e direito internacional, publicado no Rio de Janeiro em 1938, informa que ele foi "funcionário consular". 
seus atos em vida para estabelecer um princípio de justiça social. Esta é compreendida como uma concessão do topo da pirâmide e não como o resultado de um processo de luta.

Com efeito, o primeiro comentário de Gomes sobre a questão social é a inutilidade da greve para o operário, visto que tais rebeliões seriam apenas capazes de tirar dele o trabalho com que sustenta seu lar e de jogá-lo na prisão do Estado, enquanto sua esposa e seus filhos se afundam ainda mais na miséria. Exemplos ideais de proprietários piedosos seriam os inúmeros nomes de prelados e instituições religiosas citadas por Gomes ao longo do seu livro, argumento também utilizado para provar que a riqueza da Igreja é justificável pelo bom uso feito destes recursos.

Não obstante a simplicidade de suas manifestações e o tom irritantemente exagerado com o qual Gomes tece elogios ao catolicismo, seu livro possui a importância de sinalizar um novo tipo de aliança entre fé católica e atuação política, motivo pelo qual chamou a atenção de Tristão a ponto de leva-lo a escrever a seu respeito um tom positivo como o nascimento da defesa legítima da ordem constituída. Cabe avaliar o que teria ele herdado dessas reflexões a partir do momento em que ele torna mais relevante em sua avaliação, isto é, das reflexões sobre os efeitos que a Revolução de Outubro de 1930 apresentou.

Em 1931, Amoroso Lima publicou Política, livro no qual pretendia reformular os princípios filosóficos e antropológicos que pautam o exercício da política. Dessa forma, todo pensamento social que assume a premissa iluminista de que a sociedade é fruto de um contrato social recebe sua condenação. Seu contraponto parte da noção aristotélico-tomista de que os seres humanos são naturalmente destinados a viver em sociedade e que, esta, por sua vez, existe com a finalidade de promover o bem comum.

Esta seria a responsabilidade do Estado, que a governa para tal. Em oposição à noção de sociedade como o espaço de expressão dos conflitos sociais, Amoroso Lima propõe a ideia de duas sociedades perfeitas: a civil e a religiosa, sendo a finalidade da primeira promover a segunda. Em sociedades como essas, tudo é ordem e beleza, mas sem luxo nem volúpia ${ }^{217}$, isto é, sem a sobreposição dos interesses individuais ao coletivo. As relações sociais são regidas por corporações que garantem o "justo equilíbrio", opondo-se isso à ideia de agremiações que defendam os interesses particulares, da mesma forma como os conceitos de "mercado", "lucro" e

${ }^{217}$ Para citar o famoso verso de Baudelaire. 
“enriquecimento" são substituídos pela proteção à família no trabalho, preço e salário justo.

Amoroso Lima procura estabelecer uma lógica de argumentação que o faça capaz de comprovar que a família, a escola e o sindicato são os grupos naturais que precedem a sociedade, a qual se forma através de sua estrutura política mais complexa o Estado - para a proteção destas "associações naturais". A finalidade de todo o aparato social seria permitir o pleno desenvolvimento da Igreja, a legítima representante de uma realidade transcendental para a qual se voltam todos os seres humanos. A cada nova peça encaixada em seu quebra-cabeça, Amoroso Lima insiste na ideia de que existe uma natureza humana, que deveria regrar o convívio social.

Dessa forma, os seres humanos seriam naturalmente destinados à convivência com outros da mesma espécie, dentro dos grupos que regram a satisfação do instinto de viver em sociedade, por menor que seja o grupo. Desse instinto é que surgiria a família, célula mater de uma sociedade sadia e santuário a merecer toda a proteção do Estado. Esta se desdobrava na regulamentação do trabalho que não permitisse às crianças exercer profissões e restringiria seriamente a ocupação das mulheres, de modo a conferir a elas todo o tempo livre para cuidar dos filhos, caso não os tivessem (o que equivale a dizer, dentro do padrão de comportamento reprodutivo proposto pela Igreja, as mulheres solteiras) ou na necessidade de material de que tivessem uma fonte de renda complementar à do marido, a ocupação profissional deveria ser uma extensão de seu papel "natural" (novamente, na concepção da Igreja) de mãe - o trabalho em escolas, por exemplo, seria a alternativa mais viável.

Outro instinto humano era o de trabalhar e de associar-se conforme a sua ocupação, de onde resultaria a criação de sindicatos. No livro Política reafirma-se a importância dos sindicatos, pois a eles caberia garantir que a existência de interesses distintos não descambasse para o conflito, visto como a cabal comprovação de um corpo social enfermo. Para assegurar o bom funcionamento do sindicato, a Igreja era chamada a intervir, ajudando a organizá-los sindicatos e a prover os trabalhadores com alguns serviços que assegurassem a reprodução da mão de obra e a afastassem do risco de contatos com grupos de propaganda comunista. Na ausência de sindicatos católicos, os operários católicos poderiam se integrar, por ordem de preferência, aos neutros ou aos liberais, mas nunca aos de origem revolucionária. 
Em paralelo à criação do Centro D. Vital em 1922, ocorre no Rio de Janeiro um Congresso Eucarístico, iniciativa pioneira de Dom Leme que se institucionalizou na década seguinte, quando adquiriu abrangência nacional. Durante alguns dias seguidos realizaram-se grandes missas diárias e algumas sessões de estudo. O primeiro Congresso Eucarístico ocorreu na França, em 1881, mas o sentido de sua implementação no país só se torna inteligível a partir da compreensão da situação brasileira das décadas de 1920 e 1930, pois ele se tornou um modo de afirmar a identidade católica do país frente às contrariedades estabelecidas pelos inimigos (protestantes, comunistas, etc.).

Os Congressos possuem também o poder de confirmar a estrutura interna da Igreja, em suas longas procissões de cardeais, bispos, padres e diáconos organizados conforme a posição ocupada na hierarquia, ou do fato de que os clérigos são os únicos autorizados a manipular a Eucaristia, objeto de adoração. Em suma, eles teriam a finalidade de divulgar de modo cifrado algumas mensagens tanto para os próprios fieis quanto às autoridades constituídas. Em seu estudo sobre estas grandes manifestações da Igreja Católica no período, Romualdo Dias acompanhou detalhadamente as reportagens a este respeito e reproduziu, em sua análise, a visão incutida por elas no leitor sobre a participação de um povo dócil às autoridades religiosas. A partir destas descrições, Dias formula uma teoria geral sobre o sentido político destes eventos:

\begin{abstract}
A autoridade e a doutrina da ordem tiveram maior possibilidade de instalação no imaginário popular brasileiro por meio das imagens moldadas e divulgadas nesses movimentos [...] a obra de restauração católica produziu uma doutrina sobre a autoridade, na articulação entre a divulgação do princípio da ordem, a coordenação pela hierarquia, a luta no interior das consciências, a ação dos grupos intermediários e a mobilização das massas. ${ }^{218}$
\end{abstract}

As considerações expostas acima ajudam a compreender os vínculos existentes entre a criação do Centro e a realização do Congresso Eucarístico Diocesano, que não por acaso se dão ambos na mesma cidade (Rio) e no mesmo ano de 1922. Na década seguinte se realizaria o primeiro encontro de abrangência nacional em Salvador, em meio às discussões das quais resultariam a Constituição de 1934. A participação de Tristão de Athayde no Congresso Eucarístico recebeu uma ampla e positiva cobertura

${ }^{218}$ DIAS, Romualdo. Imagens de ordem: a doutrina católica sobre autoridade no Brasil (19221933). São Paulo: Ed. UNESP, 1996, pp. 131-2. 
dos principais jornais do Rio de Janeiro. As reportagens destacavam as missas campais que lotaram estádios, as diversas atividades paralelas aos grandes eventos - as procissões, as sessões de estudo, nas quais tomaram parte Amoroso Lima e Leonel Franca - e o respeito dos fiéis à figura de Dom Sebastião Leme ${ }^{219}$. O fato de ele ser bem acolhido em sua iniciativa de fazer o evento fora de sua diocese foi um forte indício da importância nacional de sua figura, haja visto que, na condição de Arcebispo do Rio de Janeiro, Dom Leme não tinha oficialmente nenhuma autoridade sobre os fiéis de Salvador.

Essas grandes aglomerações serviam, portanto, para confirmar a posição de liderança das autoridades como Dom Leme no seio inclusive da própria hierarquia. $\mathrm{O}$ tom encomiástico se estende a Amoroso Lima, que também recebem as homenagens do clero baiano $^{220}$ e dá entrevistas aos jornais do Rio sobre o Congresso. Duas delas abordaram de forma mais direta as relações entre a Igreja e o momento político atravessado pelo país. A primeira ${ }^{221}$ oferece pistas sobre as ligações de Tristão com a política no período:

O sr. Tristão de Athayde, escritor católico, nesta qualidade nomeado membro da comissão do anteprojeto da nova Constituição Brasileira, também esteve presente ao grande Congresso Eucarístico realizado na Bahia. Ali acompanhou, atentamente, neles intervindo, todos os trabalhos da imponente reunião.

A denominação "escritor católico" apresenta de forma lapidar as credenciais de Alceu para justificar sua posição de destaque. Ele é um "escritor”, um homem do saber, da razão; e ao mesmo tempo "católico", como uma indicação do tipo de cultura que ele produz. Há uma sutil, porém importante diferença, entre esta expressão usada e a do “católico escritor", na qual o peso maior estaria na condição religiosa, a partir da qual se daria a produção de textos. Em diálogo com a tese de Marcelo Tadeu Schincariol ${ }^{222}$, o modo como Tristão de Athayde é denominado pelo jornal aponta para a importância da discussão sobre a existência de um gênero de romance chamado católico. Assunto

\footnotetext{
219 “O encerramento do Congresso Eucarístico Nacional”, Correio da Manhã, 12/09/1933.

220 "O Congresso Eucarístico Nacional - Transcrição de nota do clero baiano em homenagem a Tristão de Athayde", Diário Carioca, 07/09/1933.

221 "O grande Congresso Eucarístico da Bahia -- A descrição que dele nos fez o Senhor Tristão de Athayde". Correio da Manhã, 17 de setembro de 1933.

${ }^{222}$ SCHINCARIOL, Marcelo Tadeu. A arte complexa de ser infeliz. [Tese de doutoramento] Campinas: Unicamp/Instituto de Estudos da Linguagen, 2009.
} 
polêmico entre os críticos literários do período, acusado de ser excessivamente dogmático por uns e admitido como uma reposta a um cansaço do romance social por outros, a questão ganha novos contornos quando se torna uma porta de entrada para a política. Neste aspecto, o pertencimento à religião é a condição para ingresso neste mundo.

Para o Correio da Manhã, o que interessa retratar é o prestígio de Alceu junto às autoridades eclesiais e civis, do qual resulta sua incumbência de participar da comissão que começaria a escrever um anteprojeto de Constituição. $\mathrm{O}$ jornal não menciona o fato de Alceu ter sido o presidente da Liga Eleitoral Católica, apesar de o sucesso da Liga ter confirmado o poderio da Igreja. A opção do jornal foi apresentar Alceu como um homem de letras capaz de conferir prestígio à Igreja com sua adesão à fé. Ela, por sua vez, o devolve designando-o para funções diretamente ligadas às suas demandas, no mais alto nível nacional. A confiança em Alceu aparece reforçada pela informação de que ele participou de "todos os trabalhos" do Congresso.

A sequência da reportagem permite uma segunda ligação com a política. Alceu tece elogios ao interventor do estado da Bahia, descrito como uma "alma visceralmente penetrada do sentimento religioso" e um amigo das reivindicações católicas. Elas seriam o tema de outra declaração sua, publicado à mesma época em outro jornal ${ }^{223}$; perguntado sobre as consequências práticas do Congresso para a vida do país, Alceu menciona a "lição" que o Norte estaria oferecendo sobre como manter a terra "bem nossa e bem unida". Os comentários faziam menção direta à Revolta Constitucionalista do ano anterior e aos grupos que propugnariam pela "divisão" do país, isto é, pelo fim da hegemonia da Igreja nos temas de seu interesse. A ligação mais explícita entre os dois pontos se tornou clara quando Alceu comentou outra consequência do Congresso Eucarístico, que ele sintomaticamente denominou "Constituinte Católica":

Desta nossa Constituinte Católica espero, em primeiro lugar, a confirmação do que nos revelaram as eleições de 3 de maio, isto é, que o laicismo sectário morreu com a Constituição de 1891 e que a nova Constituição dará aos brasileiros a verdadeira liberdade religiosa com a permanência de defesa da família, que a Constituição anterior já continha, e com as novas exigências de justiça social que uma sociologia sã está pedindo.

Espero ainda uma união mais íntima entre os católicos de modo que sejamos realmente uma maioria que faça prevalecer os direitos da

223 "O Congresso Eucarístico Nacional". Diário Carioca, Sábado, 09 de setembro de 1933. 
verdade, e não uma maioria acovardada diante dos arreganhos de minorias sectárias e fanáticas, que pretendem compensar pelo escândalo o seu anacronismo, a sua miopia intelectual e o seu espírito anti-brasileiro.

O atendimento aos reclamos da Igreja constituiria na visão de Alceu a expressão da vontade popular e, ao mesmo tempo, exigência da aplicação da boa ciência (a "sociologia sã", ou o contrário da sociologia doentia praticada por seus concorrentes da Faculdade de Direito do Rio Janeiro) no campo social. Ele atira aos seus inimigos as acusações que o grupo dos católicos recebia até então: dizer que eles são os sectários e anacrônicos equivale a dizer que o progresso e a razão estariam ao seu lado, isto é, tentar alterar o sentido dos termos utilizados pelos adversários.

A constatação de que a cobertura da imprensa foi claramente a favor do Congresso Eucarístico de Salvador conduz a reflexão sobre o sentido político delas. Dias trabalha com a formação do imaginário político de grandes multidões como se a reunião dos fiéis fosse a grande causa do movimento, em prejuízo das palavras proferidas nos discursos e em outros momentos. Restaria como essencial apenas a experiência do pertencimento à grande massa se compraz em agir como um corpo único, dócil na obediência à vontade do líder. Sem prejuízo das considerações sobre o efeito destas grandes concentrações sobre o imaginário, a cobertura da imprensa permite pensar que igualmente importante é a mensagem política explícita e destinada a outros grupos não diretamente ligados ao evento e à Igreja, especialmente em meio à crise política marcante dos anos 1920 e dos anos 1930.

Aos Congressos Eucarísticos deve ser somada outra experiência importante na década de 1930: a Liga Eleitoral Católica, também conhecida pela sigla LEC. Sua criação adquire sentido mais preciso no bojo do processo político seguinte à Revolta Constitucionalista de 1932, que marca o período mais turbulento do processo revolucionário desencadeado em 1930, com a perda de espaço dos grupos ligados aos tenentes, em benefício dos grupos oligárquicos que já haviam participado do levante em outubro de 1930 .

Além da recuperação de espaço dos mesmos grupos políticos financiadores do rearmamento da Igreja, Dom Leme contou com o cenário positivo gerado pela convocação de eleições para uma Assembleia Constituinte para substituir a Carta Magna de 1891, tornada sem efeito com a implantação do Governo Provisório. As condições nas quais esta nova Constituição seria discutida eram bastante distintas 
daquelas de 1891, com uma hierarquia católica dotada de uma estrutura mais sólida e mais exigente na sua relação com o Estado.

A estratégia formulada pela hierarquia da Igreja foi obter o maior número possível de assinaturas dos candidatos comprometendo-se a defender as reivindicações católicas: a validade civil do casamento religioso, a consagração do ensino religioso nas escolas e a assistência religiosa no Exército e em hospitais. Estas três medidas formavam o programa mínimo, os três pontos básicos sobre os quais todo candidato deveria estar de acordo para poder fazer parte. Além destes, havia um arcabouço de medidas sociais e econômicas que o candidato poderia aceitar ou não, para impedir o trabalho infantil, regular os preços e salários e proteger a família. Eles consistiam no programa máximo da Liga, aceita pela maioria dos aprovados à Assembleia Constituinte de 1933.

A LEC constituiu um meio de pressionar os candidatos a aceitarem a defesa das reivindicações católicas sem forçar um compromisso da Igreja de apoio a um partido em exclusivo, fato importante em meio a uma eleição polvilhada de partidos fragmentados. A proposta original, de que a LEC apresentasse pessoalmente aos candidatos uma lista de pontos com os quais ele deveria se comprometer caso fosse eleito, foi substituída por outra, a de procurar os partidos para assinar o compromisso em nome da chapa. O plano original poderia enfraquecer os partidos e servir para que a Liga se transformasse em uma frente suprapartidária, mas ela preferiu seguir outro caminho e acabou pagando um alto preço por sua visão que os conflitos que marcam a atividade política ${ }^{224}$, são sempre prejudiciais e a própria Liga jamais deveria provocar ou alimentar um conflito com as forças estabelecidas.

Sua finalidade não era criar um grupo de políticos extremamente virtuosos ou altamente qualificados, mas se antepor às disputas regionais que eram uma ameaça real no Brasil deste período. Ela foi um meio de pôr em prática um pressuposto da sociologia de Amoroso Lima: a de que a relação entre os grupos sociais deveria ocorrer de forma orgânica e hierarquizada, na qual cada grupo fosse atado ao seu lugar de origem e sem anseios de acrescentar direitos para si em detrimento dos direitos dos

\footnotetext{
${ }^{224}$ A respeito dessa visão política, conferir: CORTES, Norma. "Católicos e autoritários: Breves considerações sobre a sociologia de Alceu Amoroso Lima" Revista Intellectus, Ano I, $\mathrm{n}^{\circ}$ 1, pp. $1-14$.
} 
outros grupos. Ele foi o escolhido para o cargo de secretário-geral da Liga e seu portavoz, tendo feito diversas declarações por escrito em seu nome.

Os artigos publicados neste período por Tristão de Athayde foram coligidos no livro Indicações Políticas. Os artigos foram reunidos em ordem cronológica de publicação e os primeiros entre eles foram escritos ainda durante o período eleitoral, anterior à Constituinte. Por este motivo, a postura de Alceu é de preservar a distância que ele próprio deveria guardar frente aos partidos, e mencionar o fato de que, antes de mudar as estruturas políticas do país, era necessário que os católicos mudassem sua cultura política. Exemplo disso: um eleitor católico não poderia votar em candidatos divorcistas, como também não poderia manter uma postura privada de católico e esquecer, na hora do voto, da doutrina social da Igreja, que condena igualmente o comunismo e o liberalismo, com sua falta de consideração pela sorte do trabalhador ${ }^{225}$.

Ainda neste raciocínio inicial, só a partir da mudança nas mentes se tornaria possível desfazer o erro de apostasia da Constituição de 1891, que fundou a República. Erro a reproduzir um problema que já existia durante o Império, como demonstrava a história do próprio D. Vital que emprestava seu nome ao Centro. Durante esta fase inicial, a ênfase recai sobre os "verdadeiros processos de reforma social, a ação espiritual, o esforço pacífico, lento, recristianizador e social” ${ }^{, 26}$. A intervenção de Alceu afasta a possibilidade de identificar a causa católica com partidos e vai além ao demarcar as diferenças entre estes e a Liga Eleitoral Católica: "Todos os partidos tinham âmbitos regionais. Só a LEC manteve, do primeiro dia ao último dia, o seu caráter verdadeiramente nacional" ${ }^{227}$. Em outros trechos, ele reforça a necessidade de excluir a LEC do jogo partidário local e reprova a atitude dos bispos que fazem da LEC um instrumento de defesa do voto nos candidatos da situação, em uma mensagem cifrada a D. João Becker, arcebispo de Porto Alegre e entusiasta do regime ${ }^{228}$.

\footnotetext{
${ }^{225}$ AMOROSO LIMA, Alceu. Indicações políticas da revolução a Constituição. Rio de Janeiro, RJ: Civilização Brasileira, 1936, p. 183.

${ }^{226}$ Idem, p. 19

${ }^{227}$ Idem, p. 112.

${ }^{228} \mathrm{Na}$ condição de presidente da Junta Estadual do Rio Grande do Sul, Dom Becker distribuir circulares de ataque à Frente Única Gaúcha e apoio explícito ao Partido Republicano Riograndense, em atitude de desrespeito aos estatutos da Liga. Conferir a este respeito:

KORNIS, Mônica. "A Liga Eleitora Católica” EM: Dicionário Histórico Biográfico Brasileiro. [Versão Eletrônica.] Disponível em:

http://www.fgv.br/cpdoc/busca/Busca/BuscaConsultar.aspx (acesso em 14/04/2014)
} 
Na medida em que o processo da Constituinte se desenrola de modo favorável aos católicos, as opiniões de Alceu se movimentam em direção a uma agenda propositiva e identifica no integralismo a opção mais recomendável para os católicos. Em artigo com o sugestivo nome de "Orientações", na qual ele assume implicitamente a condição de líder não apenas da LEC mas de todo o eleitorado, Alceu comenta qual deveria ser o comportamento da mocidade católica diante dos regimes sociopolíticos emergentes e começa desprezando a alternativa do socialismo inevitável, segundo ele confirmado tanto pelos rumos tomados pela Revolução de 1930 no Brasil como pela substituição dos regimes liberais no mundo por outros que abrigavam um controle do Estado sobre a economia.

Entre os autores escolhidos por Alceu para fundamentar sua tese está Gilbert Keith Chesterton ${ }^{229}$, com sua teoria econômica do distributismo e o conceito de que a liberdade representa a vitória da iniciativa individual sobre o Estado e o poderio econômico. Na sua ótica, o distributismo implicava na valorização da pequena propriedade como a garantia material do exercício da vontade própria e, dessa forma, corrige o grande defeito estrutural a igualar o capitalismo ao comunismo, pois ambos sonegam à população a possibilidade da propriedade para a maioria. Uma legislação capaz de favorecer a pequena propriedade é aquela capaz de deter o apetite do Estado e dos grandes trustes capitalistas, cuja natureza conduz ao crescimento contínuo.

A discussão sobre a liberdade econômica se junta ao pensamento sobre várias outras liberdades (como a sindical e a de ensino) nos artigos publicados em $A \operatorname{Razão}^{230}$, de São Paulo e reunidos nos livros Contra-Revolução Espiritual e Pela reforma social, ambos editados em 1933 pela Spinola \& Fusco ${ }^{231}$, localizada na cidade de Cataguazes.

${ }^{229}$ Gilbert Keith Chesterton viveu na Inglaterra entre 1874 e 1936. Nascido em berço anglicano, converteu-se ao catolicismo, onde encontrou suporte para suas teses sobre economia e sobre teologia. Sua enorme produção inclui romances policiais que se tornaram best-sellers, livros sobre teologia, história, filosofia e economia. Também ficaram famosos seus programas de rádio, nos quais cultuou o gênero da polêmica.

${ }^{230}$ Este jornal foi fundado por Alfredo Egídio de Sousa Aranha em 1931 e teve como seu principal editor Plínio Salgado. O jornal contou com as colaborações de alguns dos fundadores do Centro Dom Vital, (Heráclito Sobral Pinto e Vilhena de Moraes), e com os artigos de Amoroso Lima. Suas páginas defendiam o fortalecimento e a centralização do Estado, baseando-se em teóricos conservadores como Azevedo Amaral e Oliveira Viana. Comungou dos ideais do fascismo e do integralismo. Embora localizado em São Paulo, posicionou-se favoravelmente às mudanças implementadas a partir de Outubro de 1930 e contra a Revolução Constitucionalista.

${ }^{231}$ A editora foi um experimento de curta duração nascido de um consórcio entre José Spínola Santos e Rosário Fusco, ambos mineiros de Cataguazes. Antes de fundar a editora, Rosário 
Os livros formam duas unidades temáticas separadas entre si, formando um par que seria como a teoria da ação social em Contra-revolução e a aplicação prática desta teoria no outro volume. Deste modo, no primeiro são identificados os grandes inimigos contra os quais os católicos brasileiros devem lutar: o laicismo, o protestantatismo e o comunismo. Alceu promove a identificação entre os três inimigos por meio da ideia de que só a escola e a família cristã são capazes de deter o avanço do comunismo e que, portanto, tudo que fosse contra o sentido cristão da vida contribuiria para seu avanço.

O sugestivo título de Pela reforma indica a defesa feita pelo autor de mudanças nas políticas públicas em torno dos temas da organização familiar, do trabalho e da educação. Em todos estes ramos, o livro reproduz a mesma metodologia: apresenta os problemas nascidos da distância entre o Estado, a burguesia e a religião, e propõe um caminho de volta. Tristão desenvolve um longo raciocínio com vistas a comprovar que as bases filosóficas sobre as quais estariam assentadas o Ocidente em seu tempo.

A teoria do livro é a de que em seu egoísmo inconsciente, a burguesia se conduz ao suicídio, e junto com ela toda a civilização. Exemplo disso seria o processo de padronização originado da formação das grandes cidades. As grandes aglomerações industriais exporiam o trabalhador a um processo de desumanização; ele se tornou um número em meio a tantos outros iguais a ele. Além disso, a convivência na cidade exporia os grupos a uma percepção mais aguda dos sofrimentos provocados pelo tipo de trabalho que se leva a cabo, impessoal e que respeita apenas a necessidade de expandir seu próprio ritmo.

O tema da Constituinte de 1933 ocupou muitas páginas na imprensa carioca e, como dela era inseparável a ação dos católicos, ela também foi comentada. O Diário Carioca se mostra bastante ácido na ironia a respeito do lobby católico na Constituinte,

Fusco já havia tentado, junto com alguns amigos, fundar uma revista literária (Verde). Apesar de tornar-se órfão de pai aos seis meses de idade e de ter de trabalhar durante os estudos para complementar a renda de sua mãe, conseguiu se formar em Direito pela Faculdade do Rio de Janeiro, cidade onde se estabeleceu profissionalmente a partir de 1932. Lá foi cronista e jornalista, tendo contribuído para colunas literárias que em 1940 se transformaram em dois livros (Vida literária e Política e letras). No terceiro volume de Estudos, Amoroso Lima escreve uma resenha positiva à poesia de Fusco. Terminou sua carreira profissional como procurador geral do Estado da Guanabara. A seu respeito, conferir:

HEDEN, Anthony. Rosário Fusco e o Estado Novo. [Dissertação de Mestrado em Literatura Brasileira] Florianópolis: Universidade Federal de Santa Catarina, 2008. 
ao comentar o trabalho de bastidores dos vitalistas em favor de Plínio Correio de Oliveira em suas diatribes contra o pastor Guaracy Silveira ${ }^{232}$ :

O sr. Plinio Corrêa de Oliveira recebeu, ontem, uma comissão de católicos que foram, em nome das autoridades competentes, levar a s. ex. o seu diploma de Menino do Côro, cargo a que s. ex. foi promovido por atos de bravura, no combate travado com o reverendo Guaracy. Compunham o grupo os srs. Tristão de Athayde, aplaudido e indigesto filósofo da Idade Média; o famigerado Schmidt, editor e padrasto do Pássaro Cego e mais dois ou três cavalheiros de aspecto messiânico. ${ }^{233}$

Entre os anos 1920 e 1940, Alceu esteve sempre presente nos bastidores da política, mas nunca ingressou em um partido político. A resposta de que ele seria obediente ao estatuto da LEC que proibia a participação em agremiações partidárias não satisfaz completamente, posto que outros lecistas desrespeitaram a regra. A reposta possa talvez ser elucidada pelo comportamento de Alceu no Conselho de Educação e na gestão da crise da Universidade do Distrito Federal. Em ambos os casos, ele demonstrou pouca disposição para ceder a compromissos políticos. No caso de Universidade, Alceu exigiu ser consultado na aprovação de todo e qualquer professor, além de não querer administrar o passivo de alunos e professores que faziam parte da Universidade de Distrito Federal.

Suas narrativas biográficas reforçam seu desapreço pela política partidária, quebrado episodicamente apenas durante a campanha civilista de Rui Barbosa. Por outro lado, sua participação na LEC deu a condição de ser o braço direito de Sebastião Leme para todos os assuntos de natureza política. O cardeal adotou uma conduta pragmática de negociar seu apoio tácito ao governo existente, independentemente do partido ou regime no poder.

\footnotetext{
${ }^{232}$ Em meu mestrado procuro demonstrar como Guaracy Silveira foi um dos nomes mais combativos em favor do Estado leigo durante a Constituinte de 1933, postura bastante distinta da que adotaria na Constituinte seguinte, em 1947. Conferir: ARDUINI, Guilherme Ramalho. "Capítulo IV: as Constituintes de 1934 e 1946". Em Busca da Idade Nova: Alceu Amoroso Lima e os Projetos Católicos de Organização Social (1928-1945). [Dissertação de Mestrado] Campinas: Unicamp, 2009, pp.111-136.

233 "O Congresso Eucarístico Nacional". Diário Carioca, 07/09/1933, p. 2.

“O Congresso Eucarístico Nacional”. Diário Carioca, 09/09/1933, p. 6.

"Nos bastidores da Assembleia". Diário Carioca, 15/12/1933, p. 3.
} 
Por este motivo, a condição de representante oficioso forçou Alceu a não se envolver diretamente nas disputas por poder. Se a posição de Dom Leme exigia de sua parte o silêncio durante a maior parte do tempo, Alceu era a voz que vinha a público justificar as escolhas feitas, conferindo a elas uma coerência construída a posteriori dos fatos. Seus escritos sobre política rotineiramente apresentam em grandes traços a situação política brasileira e internacional. Poucos são aquelas que mencionam expressamente personagens da vida pública brasileira e mundial. Uma exceção a este hábito ocorre quando Engelbert Dollfuss é assassinado, em Viena ${ }^{234}$.

O combate do líder austríaco ao comunismo e seu assassinato pelos nazistas contribuíram para justificar sua transformação em mártir, pois ele teria sacrificado sua vida pela decisão de manter-se igualmente distante dos dois extremos políticos, na visão de Alceu. Seu exemplo reverbera na análise da atuação da bancada do partido comunista no Brasil e seus discursos contra Dollfuss. Alceu enxerga uma contradição entre a defesa da revolução no Brasil por Zoroastro Gouvea, Acyr Medeiros e João Vitaca e a crítica ao uso da força - na sua opinião, em legítima defesa - no caso de Dollfuss. $O$ texto é uma ocasião para Tristão tentar interferir na Constituinte, indicando os maus deputados e os bons exemplos:

É o quadro mais perfeito da hipocrisia humana que podemos imaginar, e Barreto Campello, o destemido campeão católico na Constituinte, fez bem em verberar acremente a atitude desses deputados marxistas de duas faces, que aplaudem o assassínio pelo nazismo anti-marxista de um herói cristão; que pregam, em suas reuniões doutrinárias e políticas, a violência como única arma social eficiente e vêm agora insultar a memória de um grande estadista católico, porque reprimiu pelas armas o ataque das armas. ${ }^{235}$

A escolha por Dollfuss é complementada pela de Garcia Moreno ${ }^{236}$, espelho de dois grandes inimigos do catolicismo em sua visão: o liberalismo no século XIX e o

\footnotetext{
${ }^{234}$ Engelbert Dollfuss foi um chanceler austríaco cuja carreira esteve sempre ligada ao partido social-cristão. No poder, combateu tanto os sociais-democratas quanto os comunistas, apresentando-se como a alternativa ao nazismo e não titubeou frente ao sacrifício, para essa finalidade, das eleições democráticas. Tinha em mente implementar elementos do fascismo e do salazarismo na Áustria, mas acabou assassinado em julho de 1934 por uma tentativa de golpe dos nazistas austríacos.

${ }^{235}$ AMOROSO LIMA, Alceu. "O novo Garcia Moreno". EM: Da Tribuna e da Imprensa. Petrópolis: Vozes, 1935, p. 240.

${ }^{236}$ Presidente do Equador por dois períodos (1861-5 e 1869-1875) e eleito para um terceiro mandato, antes de ser assassinado ainda em 1875. Conteve a onda de sublevações que tomavam o país e empreendeu reformas com o fito de estrutura-lo. Era tido como conservador e elegeu a
} 
comunismo no século XX. A propaganda pelo uso da força lhe permite trabalhar o clima político da época, bastante tensionado pelos boatos constantes de uma pretensa ameaça de revolução comunista no Brasil. Dollfuss serve como anteparo para promover o debate sobre a atuação da bancada comunista durante a Constituinte de 1933, momento crucial para as pretensões políticas do grupo. Além de Alceu, outros vitalistas tentaram se firmar como vozes ativas no cenário político. O caso mais conhecido entre eles é de Sobral Pinto, sobre o qual já apresentei algumas ideias em texto para o qual remeto o leitor ${ }^{237}$ a fim de complementar as ideias apresentadas aqui.

Há uma herança de Jackson de Figueiredo no estilo e no conteúdo das crônicas de Sobral Pinto. Ao longo da década de 1920, estes dois autores selaram uma aliança duradoura: perseguir os inimigos políticos da presidência bernardista e apoiar o mineiro Affonso Penna Jr. Esta aliança política é retratada pelos biógrafos de Jackson como uma oportunidade de participar do primeiro escalão do governo Bernardes ${ }^{238}$, com quem Sobral Pinto se manteve aliado mesmo após a morte do amigo. Toda a articulação política de Minas Gerais estaria sob seu olhar atento , como registrado nas colunas políticas que publicou em A Ordem durante os primeiros anos da década de 1930.

Tendo em vista o exposto sobre as diferenças de perfil entre a dupla Figueiredo/Sobral Pinto e Amoroso Lima, cabe perguntar-se sobre o que motivou Alceu a se aproximar da opinião de Figueiredo e assumir a continuidade de suas posições políticas após sua morte. Evidências para a resposta de ambas as questões podem ser

Igreja como sua principal aliada, promovendo uma reforma do clero e a importação de jesuítas alemães, a quem também confiou algumas funções de administração pública.

${ }^{237}$ ARDUINI, Guilherme Ramalho. "O Centro D. Vital: estudo de caso de um grupo de intelectuais católicos no Rio de Janeiro entre os anos 1920 e 1940" EM: RODRIGUES, Cândido Moreira \& PAULA, Christiane Jalles de. Intelectuais e militância católica no Brasil. Cuiabá: Editora UFMT, 2012, pp. 75-95.

${ }^{238}$ Em sua biografia de Sobral Pinto, Dulles menciona a existência de uma esperança de Figueiredo em ser lançado candidato a governador do Sergipe por Affonso Penna Jr, que não nutria simpatias pela figura do então chefe da oligarquia local, Gilberto Amado. O plano era que o governador Maurício Graccho Cardoso escolhesse Jackson para sua sucessão, mas um acordo político de última hora entre Cardoso e Amado frustrou estes planos, conferindo a outro aliado de Cardoso o posto de governador e reservando a Amado o cargo de Senador.

Ao escrever sobre seu pai, Cléa Figueiredo é mais vaga. Apenas faz referência a um sentimento de frustração que Jackson teria mantido por ter sido chamado por Bernardes a dar suas opiniões, mas nunca encontrar alguém que as levasse a sério.

DULLES, John W. F. Sobral Pinto: A consciência do Brasil: a cruzada contra o regime Vargas (1930-1945). Rio de Janeiro: Nova Fronteira, 1991.

FERNANDES, Cléa de Figueiredo. Jackson de Figueiredo: uma trajetória apaixonada. Rio de Janeiro: Forense Universitária, 1989. 
encontradas a partir da correspondência trocada por eles entre 1920 e 1928, posteriormente reunida em livro. ${ }^{239}$

As cartas demonstram que os temas tratados eram variados e envolviam desde a política até questões culturais, além uma troca constante de favores, com pedidos feitos por Jackson para Alceu em benefício de seus amigos ${ }^{240}$. Há diversas demonstrações de afeto, a começar pelos vocativos ("querido Jackson", "meu querido Alceu"), prosseguindo pelos elogios constantes aos livros e artigos publicados de ambos os lados. Um exemplo disso: a dedicatória de Jackson a Alceu em seu livro Afirmações "toca o coração" deste. As longas missivas intercambiadas de parte a parte permitem enxergar as aproximações dos pontos de vista existentes logo de partida: os dois são fiduciários da substituição da ordem liberal por outra, ancorada na Autoridade como o elemento central da organização social. Mas a defesa de tais princípios se dá por motivos distintos, conforme Alceu deixa entrever em carta de 1923:

Sou, como você, um espírito conservador em política, embora julgue que essas minhas ideias precisem de uma certa atenuação, em virtude da situação que tenho. Só homens como você, a quem a nossa Sociedade não recompensa nem com um milésimo do valor que possuem, podem defende-la de cabeça erguida, pois nada tem a perder com a sua queda. ${ }^{241}$

A franqueza demonstrada nesta passagem está em paralelo com a consciência de Alceu da distância social que separa ambos, e com a diferença de interesses materiais em jogo entre os dois. $\mathrm{O}$ fato de Alceu mencionar tais interesses é tanto mais digno de nota pelo fato de Alceu defender-se da "acusação" de Jackson de ser materialista. Existe, porém, algo que os une, e isto se torna evidente quando Alceu revela o desajuste com o meio social no qual vive. Em termos políticos, tal desajuste se expressaria por meio da descrença nos valores democráticos que caracterizariam os membros de seu entorno.

239 AMOROSO LIMA, Alceu \& FIGUEIREDO, Jackson. Correspondência: harmonia dos contrastes. Rio de Janeiro: Academia Brasileira de Letras, 1991.

${ }^{240}$ Exemplo disso é o emprego que Alceu consegue para Perillo Gomes em um escritório de Engenharia, a pedido de Jackson, conforme carta de 20 de março de 1924.

${ }^{241}$ AMOROSO LIMA, Alceu \& FIGUEIREDO, Jackson. Correspondência: harmonia dos contrastes. Rio de Janeiro: Academia Brasileira de Letras, 1991, p. 63. Carta de Alceu a Jackson, 2 de fevereiro de 1923. 
Esta posição em descompasso provocou da parte de Alceu dúvidas e inquietações que serviram de matéria-prima para o trabalho de convencimento proposto por Jackson de Figueiredo. Este se utilizou de todos os meios possíveis para apresentar a doutrina social da Igreja como a única resposta para as inquietações políticas do amigo. Tristão cede aos poucos inicialmente reconhecendo na Igreja a garantia da ordem estabelecida, pois ela seria a "fonte dos prazeres mais profundos e duradouros que podemos ter, que são os baseados na tranquilidade da alma" ${ }^{242}$. Por outro lado, considera a necessidade de ordem como algo da ordem do psíquico, imanente à condição humana e não transcendente a ela. Figueiredo mistura o religioso com o político na resposta.

A atuação política não se resumiu aos nomes de Tristão e Jackson: Miceli (2001) analisou a participação de Leonel Franca e Amoroso Lima na expansão da rede católica de ensino. Cumpre conhecer outras frentes de atuação do inaciano, como a associação Santo Ivo, fundada em 1929 no Rio de Janeiro por magistrados e advogados católicos. Embora Leonel Franca tenha sido determinado o assistente eclesiástico desde a criação da Associação, sua presença se faz perceber principalmente a partir de Outubro de 1930. A vitória da Revolução mudou os interlocutores com os quais a Igreja precisava negociar a revisão de seu estatuto frente ao Estado e a associação teve a oportunidade de trabalhar em favor dos objetivos traçados por Dom Leme, isto é, rever o estatuto de proximidade entre a Igreja e o Estado.

O primeiro ponto ao qual Franca se dedicou foi o ensino religioso: ele sugeriu uma nova redação para o $\S 6^{\circ}$ do art. 72 da Constituição Federal, de modo a obter para o catolicismo algo mais do que a simples igualdade de tratamento em relação a outras religiões. No dia 14 de abril de 1931, Franca se reuniu com Francisco Campos, então Ministro da Educação. No dia 30 do mesmo mês, o decreto que autoriza as escolas públicas a instituir o ensino religioso é assinado por Vargas. Na semana da Consagração de Nossa Senhora Aparecida como a padroeira do país, Franca publica seu livro sobre o divórcio e entrega a Dom Leme um novo plano das reivindicações católicas.

A porta de entrada para compreender o sentido que ele próprio atribuía às suas ações são os artigos e palestras proferidos durante o período, reunidos postumamente na obra Alocuções e artigos. A palestra de Franca na fundação da Sociedade Santo Ivo, por exemplo, é uma ocasião para ele descrever sua opinião a respeito do momento coevo.

${ }^{242}$ P. 50. Carta de Alceu a Jackson, 17 de outubro de 1922. 
Ele desenha um painel de caos social, inspirando-se em Spengler e sua tese de decadência do Ocidente. A crise social envolveria desde o aumento da criminalidade juvenil até a dissolução da estabilidade da família.

A solução para este clima de caos estaria na ação da Igreja, descrita como um tiers parti que representasse perfeitamente o equilíbrio de opostos. Ela defenderia a democracia tanto do autoritarismo quanto da demagogia, lembrando a todos a necessidade de respeitar a autoridade constituída e a esta, a de trabalhar pelo bem dos cidadãos. $\mathrm{Na}$ área econômica, torna o capitalismo responsável pelos direitos negados aos cidadãos, mas impede os proletários de ultrapassarem o limite de suas "justas" reivindicações. A conclusão do artigo apresenta uma apologia da Igreja que não se traduz em nenhuma medida efetiva:

\footnotetext{
Numa palavra, sobre todas as grandes questões da nossa vida individual e social, intelectual, moral e religiosa, a Igreja tem afirmações nítidas que são palavras de vida, ela, a depositária divina das verdades indispensáveis à humanidade, ela, a mantenedora incorruptível da jerarquia essencial dos valores humanos. ${ }^{243}$
}

Embora mencione a defesa dos direitos dos mais fracos como um dos objetivos da Associação, Franca não define de modo claro qual deveria ser esta atuação ou como ela poderia se desenvolver no interior do cenário existente. No momento de sua criação, a Associação Santo Ivo não possuía a importância que viria a ganhar a partir da Revolução de 1930.

Os textos de Franca da década de 1930 deixam claro seu apoio à Liga Eleitoral Católica, instrumento para moralizar uma atividade política e redefini-la a partir de princípios religiosos. As mudanças mais significativas no seu modo de pensar se deram durante a década de 1940, quando Franca partilhou da preocupação de Amoroso Lima e de outros vitalistas de realizar uma leitura da doutrina católica capaz de conciliá-la com a volta da supremacia dos regimes democráticos. Há uma mudança também nos meios de transmissão de suas palestras, que saem dos salões e corredores das organizações católicas para atingir um público amplo e difuso, através das ondas do rádio ${ }^{244}$.

\footnotetext{
${ }^{243}$ FRANCA, Leonel. "A Igreja e a crise social”, FRANCA, Leonel. Alocuções e Artigos Tomo I. Rio de Janeiro: Agir, 1954, p. 386.

${ }^{244}$ FRANCA, Leonel. "A Liga Eleitoral Católica”, EM: Alocuções e artigos, Rio De Janeiro: Agir Editora, 1956, pp. 115-118. (da coleção Obras completas de Leonel Franca)
} 
Nestas alocuções, nota-se a preocupação em reafirmar que a Igreja sustentava uma postura democrática, como se os valores cristãos fossem os únicos que pudessem conviver com um período em que a diversidade fosse respeitada e todos os interesses, mesmo os mais conflitantes, deveriam possuir um representante na mesa de negociações. No final da década de 1940, Leonel Franca demonstra o ensejo de reformular o vocabulário do debate entre o Estado e os católicos para inserir as questões próprias ao jogo democrático, caminho obrigatório para o Brasil saído do Estado Novo e da II Guerra Mundial.

A mudança registrada na interpretação que Franca oferece da situação política contrasta com a manutenção das posturas autoritárias por outros vitalistas, como Jonathas Serrano, cujo interesse sobre a política se dá a partir da intersecção entre ela e a função social da escola. Esta instituição, serviram para difundir a boa formação moral, de modo a conduzir os cidadãos a entender que a política deveria ser regida pelo interesse comum, sem admitir as divisões por grupos de interesse característicos do liberalismo. A paz social seria melhor obtida por meio de um líder capaz de conduzir sua sociedade em meio a este processo. Serrano identifica este líder a Vargas. Em um artigo de 1940 intitulado simplesmente "Brasil" (BARBOSA, 2011). O balanço apresentado é altamente positivo: graças a Vargas, o Brasil se preparava para um futuro grandioso pela frente.

$\mathrm{Na}$ avaliação de Serrano, os pontos mais positivos do governo de Vargas seriam o fato de ele ter chegado ao poder sem o derramamento de sangue; a manutenção da ordem social no país, com melhoria na qualidade de vida da maioria da população e, acima de tudo, a manutenção da fé católica e o respeito às tradições católicas do país. Sua tradição positivista e sua atuação como deputado - quando proferiu discursos condenando a religião como uma invenção humana e lutou contra as propostas da Igreja - foram completamente ignoradas por Serrano, que prefere transformá-lo em exemplo mundial de líder.

A morte de Serrano em 1944 nos impede de saber o que ele pensaria sobre o final do Estado Novo. Este é, aliás, outro momento de adensamento nas discussões sobre como deve ser a política em âmbito nacional, tendo em vista o crescente movimento para a saída de Vargas do poder. Liberto da fidelidade a D. Leme, morto em 1942, e preterido por D. Jayme Câmara, seu sucessor, Alceu não teve dificuldades para aderir ao movimento pela derrubada de Vargas, tendo externado sua opinião no I 
Congresso Brasileiro de Escritores (janeiro de 1945). Profissionalmente, Alceu já havia se estabilizado como professor da PUC-RJ, da Universidade do Brasil, membro da Academia Brasileira de Letras e do Conselho Nacional de Educação - em resumo, uma carreira de largo sucesso.

Contudo, apenas as mudanças em sua condição social - ou mais precisamente, a confirmação da trajetória já projetada durante a década de 1930 - não seriam suficientes para explicar o novo posicionamento. Elas ajudam a entender o que tornou possível que ele acompanhasse o filósofo francês Jacques Maritain, base filosófica de seus escritos desde a década de 1920, na sua abertura para a defesa da democracia como o regime mais condizente com os valores do cristianismo ${ }^{245}$. Este percurso intelectual foi estudado por Cândido Moreira Rodrigues em sua tese de doutoramento ${ }^{246}$, que se interessa pela influência de Jacques Maritain no pensamento de Tristão de Athayde.

Para Rodrigues, a mudança de visão do mundo do filósofo francês, iniciada pela condenação da Action Française em 1927, repercutiu lenta e gradualmente nos escritos de Tristão. Data importante dentro desse processo foi a publicação de Humanismo Integral, em 1936, pois ao tomar contato com a obra, o intelectual brasileiro começou a assumir mais claramente o distanciamento em relação ao seu ponto de vista anterior. No entanto, ainda seria necessária mais uma década para que a mudança se desse de forma definitiva. Ao fim do Estado Novo, enquanto a hierarquia católica mantinha-se em silêncio sobre o fim do regime, Amoroso Lima assumia uma postura marcadamente favorável à volta da democracia:

Não basta, a meu ver, voltar ao regime anterior. Quando se dá uma
revolução política vitoriosa e que consegue durar por alguns anos é a
prova patente de que havia no organismo social uma distrofia qualquer
que exige atenta reparação. Para que a democracia venha a ser um fato
no Brasil, é mister que se afastem alguns males sociais, que impedem
o seu funcionamento normal, como sejam o exagerado centralismo
político, a hipertrofia do Executivo, a perpetuação no Poder, as
oligarquias estaduais, o absenteísmo eleitoral e particularmente o
ceticismo jurídico e o capitalismo plutocrático. Os quadros

${ }^{245}$ Em resenha sobre o livro Humanismo Integral, publicada em 1944, Amoroso Lima escreve: "A base da Democracia é religiosa e especificamente Cristã em sua essência; a base do Liberalismo é secular. A Democracia fala do homem como sujeito à disciplina de regras morais absolutas, pugnando por um destino que é espiritual; o Liberalismo desconhece essa espécie de homem." Retirado de:

AMOROSO LIMA, Alceu. "A Posição dos Católicos frente ao liberalismo e à democracia” EM: A Ordem, outubro de 1944, p. 345.

${ }^{246}$ RODRIGUES, Cândido Moreira. Aproximações e conversões... 
tradicionais da política nacional, dentro dos partidos regionais, não foi capaz de resolver o problema político de nossa terra, tanto assim que a Revolução de 1930 foi incontestavelmente recebida, pela opinião pública, como uma solução salvadora. ${ }^{247}$

Ao lembrar de como a Revolução de 1930 foi acolhida como a salvadora, Tristão de Athayde não pretende revalorizar Vargas - pelo contrário, basta lembrar que ele participou de comícios em favor de Eduardo Gomes, juntando-se ao núcleo mais duro de resistência ao ditador e sua herança. Ao comentar o período anterior ao Golpe de Estado que deu início aos quinze anos de governo interrupto do entancieiro de São Borja, sua análise se modificou consideravelmente. Se antes o problema eram os partidos políticos, agora são as "oligarquias estaduais" e o "capitalismo plutocrático". Embora com reflexos na política, o problema passa a ser social: é preciso alterar a Igreja em suas bases mais estruturais.

247 "Uma entrevista de Tristão de Athayde", A Ordem, abril de 1945, pp. 317-322. 
CONSIDERAÇÕES FINAIS 
Esta tese se debruçou sobre um grupo de profissionais liberais e universitários estabelecidos no Rio de Janeiro durante as décadas de 1920 a 1940, que se identificaram com a defesa das demandas da Igreja Católica e tiveram diversas frentes de atuação. Eles frequentaram um espaço que escolheram chamar de "Centro Dom Vital", em clara referência ao bispo que se envolveu com a questão religiosa no final do Império. $\mathrm{O}$ nome se pretendia um anúncio dos interesses que levaram tantos homens e algumas poucas mulheres a frequentarem o prédio de estilo colonial da praça $\mathrm{XV}$, onde o Centro se instalou em seu período de maior esplendor.

A discussão sobre as relações entre a política e a religião animaria muitas noites de reuniões e palestras, desde sua fundação por Jackson de Figueiredo. Ele foi descrito como a figura por excelência do "soldado da Igreja" e modelo para os outros vitalistas. A atividade intelectual era vista por eles como uma adesão às causas determinadas pela hierarquia, e em especial pelo Cardeal Leme, arcebispo do Rio de Janeiro. Não se trata de rebaixar a importância deste fenômeno, mas notar que o espaço para a criatividade e as diferenças de visão no interior do grupo passam obrigatoriamente pelo tratamento de temas de interesse e das opiniões chancelados pelas autoridades religiosas. A produção intelectual e o sentido político da ação tomada se mesclam para originar um hibridismo a meio caminho entre o proselitismo puro e simples e a pesquisa científica séria, preocupada com as evidências.

A substituição de líder após sua morte em 1928 poderia ter significado uma pura e simples substituição do elemento político pelo cultural; era isso o que anunciava o novo presidente do Centro, Tristão de Athayde. Entretanto, o transcorrer dos acontecimentos de 1930 em diante levou o Estado e a Igreja a renegociarem o pacto de apoio mútuo. Estes entendimentos, iniciados no escalão mais alto das duas hierarquias, isto é, entre Dom Leme e Getúlio Vargas, reproduziu-se em níveis de atuação mais baixos, como demonstrou o caso de arregimentação de intelectuais do Centro no Rio e em Recife para órgãos estaduais/distritais e para ministérios do Executivo Federal.

No primeiro capítulo, a tese tratou de limitar a problemática em estudo a partir dos aspectos ainda pouco estudados pela bibliografia a respeito das complexas relações entre os intelectuais e a elite dirigente do país. Por meio de uma retomada das diferentes interpretações disponíveis, apresentou-se o problema central do trabalho, isto é, compreender a complementaridade e as tensões existentes entre um grupo de leigos que almeja obter posições de destaque na cena política e cultural brasileira, uma hierarquia 
religiosa carente de mão de obra para manter seu ritmo de expansão sobre o ensino e outras esferas da vida pública nacional e uma burocracia federal também em fase de expansão. O que estava em jogo era a administração dos meios de reprodução simbólica de dominação social, em especial nas instituições que atendiam operários e estudantes.

Entre os leigos, clérigos e burocratas são estabelecidas algumas alianças e tensões e para compreendê-las procurou-se levar em conta as diversidades internas aos três grupos e os interesses nem sempre convergentes entre eles. Em especial no que tange à elite política, o período do Governo Provisório (1930-1934) foi especialmente sensível às disputas por uma alteração nas políticas públicas ligadas à educação e ao trabalho. Neste sentido é que se desenvolveram as disputas em torno do ensino religioso e da pluralidade sindical, nas quais os vitalistas representaram a alternativa mais conservadora do status quo.

Entender o desenrolar destas e das demais questões nas quais se envolveram os vitalistas foi o papel dos capítulos seguintes da tese, a começar por uma análise morfológica do grupo, tema do segundo capítulo. O objetivo era conferir clareza ao processo que transformou um espaço de sociabilidade em usina de criação de projetos de intervenção cultural e política e arregimentação da mão de obra para ocupação de espaços na imprensa, nas editoras, nas escolas e na administração pública. Para expressar melhor este fenômeno, deu-se a ele o nome de vitalismo e aos elementos que o fomentaram, o de vitalista.

Algumas contribuições teórico-metodológicas foram essenciais, como o tipo de biografia coletiva aplicado por Sergio Miceli no estudo dos bispos brasileiros da Primeira República. O uso da biografia coletiva para a leitura de um conjunto de livros, tal como feito por Miceli, exige uma reflexão sobre os propriedades sociais dos autores e o diálogo que elas estabelecem com as características de sua produção escrita. Esta pode ser compreendida como a materialização do diálogo entre as aspirações de reconhecimento de seus autores e as contingências sociais que as limitam. A formação escolar, o círculo de contatos familiares, cabedal cultural e outros elementos marcantes da experiência se traduzem por um gosto estético e estilo de escrita, de modo a se converterem em instrumentos de luta pela valorização do trabalho.

Das reflexões de Christophe Charle e Lawrence Stone sobre a prosopografia provem outro aporte relevante para esta tese: restringir a lente de análise para uma escala mais reduzida, que permita observar com maiores detalhes as mudanças nos 
membros do grupo. Se o prejuízo dessa escolha reside em estabelecer menos vínculos entre o grupo em estudo e o contexto no qual está inserido, por outro lado ele apresenta a possibilidade de trabalhar de forma mais elaborada os laços a atar os membros do grupo entre si, isto é, o que separa "eles" de "nós" e como esta identidade é negociada por cada membro do grupo em relação ao que este apresenta de singular.

Neste tópico, uma análise da trajetória social demonstrou que os fundadores do Centro possuíam algumas características em comum: a formação em Direito na Faculdade do Rio de Janeiro, uma carreira prévia em áreas ligadas à educação e a consagração em gêneros que não estavam entre os mais valorizados do período. Somese a tudo isso o fato de eles terem nascido junto com a República e terem assumido (ou voltado a assumir) a fé católica entre o final da adolescência e o início da vida adulta. A este grupo viria se somar outros a atingir a juventude da década de 1930, cujas experiências já incluíam na maioria das vezes a passagem pela Ação Universitária Católica, grupo bastante ativo nas faculdades de Direito do país.

Este espantoso fenômeno de conversão em massa só se torna inteligível quando se observa a formação de estruturas de sociabilidade capazes de acompanhar uma pessoa desde sua primeira infância até a vida adulta. Nem todos os vitalistas frequentaram escolas católicas; entre as primeiras gerações, só a minoria. Mas todos eles tiveram motivos para - geralmente através de um amigo - enxergarem no Centro uma solução para suas dificuldades, dos mais variados tipos: incentivo para suas aspirações a escritor, uma crise familiar, problemas de inserção na cidade (no caso dos migrantes)... Nem todos os fatores, portanto, de origem intelectual, um indício importante para compreender as razões de existência do grupo.

Por meio de artigos na imprensa carioca, de livros e de cargos ocupados na administração pública federal - notadamente nos Ministérios da Educação e do Trabalho - estes personagens fizeram emergir uma nova figura de intelectual e de militante religioso, com suas ambiguidades internas e consequências para as políticas públicas e produções culturais do período. A principal ambiguidade foi descrita pelo capítulo II e residia na própria definição de sua atividade como "a formação de uma cultura superior", ou "centro de intelectualidade", para utilizar as palavras dos próprios vitalistas. Ela resultou da delicada posição social ocupada por eles, em relação aos outros fiéis da Igreja Católica e aos letrados do período. Em relação ao primeiro grupo, representavam uma elite cuja legitimidade era dada por sua capacidade de se 
demonstrarem uma erudição acima da média. Consideravam necessário justificar sua fé como o resultado de uma opção lógica e racional e encetaram iniciativas para transmitir este tipo de catolicismo ao conjunto de fiéis por meio das equipes sociais com os operários, dos artigos de O Jornal ou da participação em Congressos Eucarísticos.

Em relação aos demais intelectuais do período, a identidade do grupo se constituía pelo valor inverso, isto é, por representar algo a mais do que a "simples" erudição. É neste sentido que o terceiro capítulo analisa tanto o "Adeus à disponibilidade", com o qual Tristão de Athayde torna pública sua decisão de aderir ao grupo em 1928, quanto a longa série de evidências em suas crônicas que apontam para uma crescente convergência de opiniões. O fato de o "Adeus" ser escrito em forma de carta a Sergio Buarque de Holanda personifica o diálogo com a cultura brasileira do período naquele que, segundo Alceu, seria seu melhor represente. Realiza, ainda, uma densa reflexão sobre os rumos da cultura ocidental a partir de alguns nomes estratégicos, em uma lista iniciada por Descartes e Kant, mas que alcança os autores contemporâneos ao texto. Em traços mais simples, a conclusão apresentada é a de que a valorização de uma cultura distante da transcendência só alcançaria a finalidade inversa da qual se propunha. Ao invés da crença ingênua no progresso da humanidade, marcante no período em formação da geração que iniciou o Centro, o espírito da Belle Époque resultou nos exemplos da I Guerra Mundial, das ditaduras estabelecidas nos países europeus e o niilismo das vanguardas artísticas mais radicais. A esta síntese geral o capítulo acrescenta a análise dos escritos de Figueiredo sobre arte e cultura.

Detectados os motivos da crise, o grupo se incumbe da tarefa de apontar os caminhos a seguir, objeto de análise do capítulo IV. As obras deste grupo se espraiaram por diversos temas, sempre com vistas a remodelar a paisagem cultural brasileira e defender as formas "corretas" de produzir arte, literatura, filosofia e ciência social, entre outros. Destes livros e escritos surgem arcabouços teóricos que submetiam o saber científico à especulação teológica, resguardando assim o estatuto de verdade central à ortodoxia católica. Este modo de pensar encontrou guarida em cursos universitários do período, nos livros e revistas publicados pelo grupo (A Ordem e A Vida) e nos espaços concedidos pelos periódicos de grande circulação da cidade do Rio de Janeiro.

Para compreender a importância do grupo, é necessário lembrar os projetos derrotados por ele, como a da Universidade do Distrito Federal e as reformas educacionais propostas pela Escola Nova. A vitória sobreveio mesmo após as 
experiências fracassadas de Amoroso Lima nos dois concursos para catedrático da Faculdade Livre do Distrito Federal, ambos em 1932. Desde o período de Francisco Campos como o primeiro Ministro da Educação de Vargas, a Igreja manteve boas relações com o recém-criado órgão. Mas a virada de sorte dos vitalistas veio de fato com a ascensão ao cargo de Gustavo Capanema, forte aliado do grupo - especialmente de Alceu Amoroso Lima -- e interessado em manter em suas mãos o monopólio sobre as universidades fundadas na capital federal.

Capanema ajudou a isolar alguns dos principais nomes da Escola Nova e transformá-la em um conjunto de inovações técnicas aplicadas se e quando não resultassem em um contestação do modelo escolar imposto pelo governo. O crescimento da força dos católicos despertou a ira de alguns dos nomes mais importantes na cena cultural, como Oswald de Andrade ou Hermes Lima, que deixaram registrado nos jornais seu repúdio ao processo de controle do ministério pelos católicos.

O corolário do processo de inovações por meio da tradição é o pensamento a respeito do próprio grupo, ou em um âmbito mais geral das definições do que é a religião católica e do que é o intelectual católico. Este é o tema do capítulo $\mathrm{V}$ da tese, que abriga a análise das obras apologéticas e hagiográficas do grupo. Destas obras emergem três figuras centrais: D. Leme, a servir de patrono e mecenas e seus filhos prediletos: Figueiredo (o profeta) e Franca (o asceta). As construções destas figuras modelares são oriundas de um processo marcado por certas ambiguidades, como fica patente na descrição de dom Leme. Ele é o intelectual acima de todos os outros porque suas obras estão escritas no seu legado, do qual faz parte o próprio Centro. O motivo da atividade intelectual é definido pelo grupo como algo exterior a si mesmo, não como a simples reflexão desinteressada.

Os modelos de hagiografia poder variar entre si, conforme a característica que se deseja enfatizar como necessária para o leitor da obra. O uso de Jackson de Figueiredo (objeto de três obras) faz jus ao predomínio dessa figura na cena pública católica na década de 1920, mas, é preciso pensar no sentido que Júlio Maria tem neste meio, comparável de Farias Brito. Os dois servem de anteparo para grupos distintos de católicos, o primeiro àqueles que desejavam estabelecer o diálogo entre catolicismo e regime publicano, enquanto os fãs de Farias Brito eram aqueles que tinham mais dificuldade de se inserir na vida moderna. 
No campo da política, tema de interesse do último capítulo, a atuação do grupo foi para além da Liga Eleitoral Católica. Ela funcionou sobretudo na eleição para a Constituinte de 1933, quando estabeleceu uma estratégia nacional nacional em meio a tantas estruturas estaduais de partidos. Impôs suas reivindicações mínimas a um grande número de deputados constituintes, mas recusou-se a sobrepuja-los, reduzindo sua área de atuação a alguns pontos em específico. Além da liga, alguns dos membros do Centro tiveram uma atuação destacada nos bastidores da Constituinte ou nos órgãos de controle das políticas públicas ligadas à educação, como foram os casos de Amoroso Lima, Leonel Franca e, em menor grau, Jonathas Serrano.

No caso de Jackson de Figueiredo, a opção foi de mergulhar na defesa do poder constituído na década de 1920, ao contrário de Amoroso Lima e Leonel Franca, que preferiram se manter distantes da política partidária. Mesmo quando convidados para ser candidato a cargos políticos ou ocupar postos de confiança na administração federal, os dois recusaram, exceto no caso em que esse convite vinha marcado pela defesa de um interesse específico da Igreja, como foi o caso das vagas ocupadas no Conselho Nacional de Educação. Além dessa atuação direta no campo da política, e de modo paralelo ao que grupo produziu em termos de visão de História, estes autores formaram em seu conjunto de obras uma hagiografia política, com exemplos (históricos ou inventados) de bons governantes, nos quais os políticos do país deveriam se inspirar.

Por fim, uma comparação com os militantes comunistas permite vislumbrar um paradoxo na trajetória destes personagens em relação aos vitalistas. Se os comunistas eram oriundos de famílias mais tradicionalmente ligadas ao poder, os vitalistas obtiveram de sua ligação com as instituições eclesiais ganhos mais imediatos ao longo das décadas de 1930 e 1940, dos quais é um caso típico o convite para assumir aulas em três das principais experiências universitárias cariocas no período: a Universidade do Brasil, a PUC-RJ e o Instituto Santa Úrsula. Por outro lado, comunistas e vitalistas têm muito em comum, como os dilemas e a conformidade imposta pela organização que patrocina o reconhecimento de seu nome como válido na arena intelectual.

Por último, também é necessário levar em consideração os limites na atuação deste grupo. O sucesso desta trajetória coletiva esteve intimamente ligada ao posicionamento disciplinado do grupo frente a algumas questões específicas, das quais poderia advir alguma forma de retorno (material ou simbólico) de interesse para o grupo: a aprovação de uma lei pela qual eles tivessem pugnado, a possibilidade de 
preencher um cargo junto à administração federal, entre outros exemplos possíveis. Por outro lado, as discussões promovidas pelo grupo não se aprofundaram nas questões, tanto as de cunho mais amplo do ponto de vista teológico quanto do ponto de vista político, isto é, de discussão dos rumos tomados pelo país.

Os exemplos das implicações do que se pretende dizer são vários: a campanha pela aprovação do ensino religioso não entrou no mérito do tipo de ensinamento que deveria constituir essa disciplina ou na necessidade de tomar medidas efetivas para universalizar a educação básica. Na política, o interesse em abrir a possibilidade de que os defensores de todos os regimes - o monarquista, o republicano mais autoritário ou o mais aberto à questões liberais - pudessem se identificar com a causa católica significou a renúncia em trabalhar para a constituição de um pensamento próprio, um grupo que tivesse uma alternativa concreta de mudança no regime.

Neste sentido, o período mais efetivo de atuação do grupo foi aquele iniciado pela golpe de Outubro de 1930 e findado com a aprovação da nova Constituição, em 1934. Dadas a configuração política desta quadra histórica, prenhe de alternativas políticas, foi paradoxalmente o momento em que o projeto político da Igreja sofreu maiores abalos e onde havia as alternativas mais promissoras para intelectuais católicos leigos. Na medida em que as alternativas mais conservadoras dão o tom da revolução de 1930, tal como se torna mais configurado a partir do final da Revolução Constitucionalista, o Centro consegue posicionar seus membros em alguns postoschave na administração do regime. 
A ORDEM. Rio de Janeiro: Centro Dom Vital, ano VIII, n. especial, mar. 1929.

A REFORMA do ensino e a escola nova, A Esquerda, 10 maio 1928, p. 1.

ACADEMIAS e escolas: ação universitária católica. Correio da Manhã, 02 jun. 1933, p. 8 .

AÇÃO Universitária Católica. Correio da Manhã, Rio de Janeiro, 02 jun. 1933. Academias e escolas, p. 8.

ALMEIDA, Lacerda de. Mais um livro sobre Farias Brito. Gazeta de Notícias, Rio de Janeiro, 08 set. 1919.

ANDRADE, Oswald de. Contra-indicações, Diário de Notícias, Rio de Janeiro, p. 2, 08 jun. 1933.

ANDRADE, Oswald de. Só para homens, A Manhã, Rio de Janeiro, 19 maio 1935. De literatura, p. 6.

ARDUINI, Guilherme Ramalho. Em busca da Idade Nova: Alceu Amoroso Lima e os projetos católicos de Organização Social (1928-1945). 2009. 156f. Dissertação (Mestrado em História Social) - Instituto de Filosofia e Ciências Humanas - IFCH, UNICAMP, Campinas, 2009.

ARDUINI, Guilherme Ramalho. Padre Leonel Franca, SJ: o centro de gravidade da sociabilidade católica carioca (1918-1948). In: RODRIGUES, Cândido; ZANOTTO, Gizele (Org.). Catolicismos e sociabilidade intelectual no Brasil e na Argentina. Cuiabá: EdUFMT, 2013, p. 31-54.

ARIÈS, Phillipe. O Tempo da História. Rio de Janeiro: Editora Francisco Alves, 1989.

AS BASES fascistas-clericaes do plano nacional de educação, A Manhã, Rio de Janeiro, p. 1; 7, 25 jun. 1935.

AS GRANDES directrizes da educação. Diário Carioca, Rio de Janeiro, 26 mar. 1936. Noticiário, p. 3.

ATHAYDE, Tristão de. Encruzilhada: a última etapa Fordlandia. Correio da Manhã, Rio de Janeiro, p. 5, 29 nov. 1931.

ATHAYDE, Tristão de. Haverá uma crise de espírito no mundo moderno? Quaes seus efeitos no Brasil?, Diário de Notícias, Rio de Janeiro, p. 1; 5,14 jun. 1932. Entrevista concedida a Renato de Almeida, Diário de Notícias.

AZZI, Riolando. Os pioneiros do Centro D. Vital. Rio de Janeiro, 2003, 307 p. 
BAKHTIN, Mikhail. A hagiografia. In: . Estética da criação verbal. São Paulo: Martins Fontes, 1997, p. 198-200.

BACKHEUSER, Everardo. Os dois pólos da terra: ensaio anti-bolchevista. A Ordem, Rio de Janeiro, ano XII, n. 15, p. 282-284, maio 1931.

BARBOSA, Flávio André Rodrigues. O sanatório das almas: reação católica e radicalização política na década de 1930 no discurso de Jonathas Serrano. Rio de Janeiro: Universidade Federal Fluminense, 2011.

BECKER, Howard. Los mundos del arte: sociología del trabajo artístico. Bernal: Universidad Nacional de Quilmes, 2008.

BOLETIM DA COLIGAÇÃO CATÓLICA BRASILEIRA, Rio de Janeiro, dez. 1936.

BOURDIEU, Pierre. Apêndice 1: A ilusão biográfica. In: Razões Práticas: sobre a teoria da ação. Campinas: Papirus, 1996, p. 74-82.

BOURDIEU, Pierre. As regras da arte: gênese e estrutura do campo literário. São Paulo: Cia das Letras, 1996.

BOURDIEU, Pierre. Campo Intelectual, campo de poder. Buenos Aires: Montressor, 2002.

BOURDIEU, Pierre. Homo Academicus. Paris: Éditions de Minuit, 1984.

BOURDIEU, Pierre. The political onthology of Martin Heidegger. Stanford: Stanford University Press, 1991.

BOURDIEU, Pierre. Site effects. In: The Weight of the World, Social Suffering in Contemporary Society. Stanford: Stanford University Press, 1999, p. 126138.

BRAGA, Rubem. Tempo e eternidade, A Manhã, Rio de Janeiro, p. 3, 30 jul. 1935.

BRUNO, Silva. A sociologia confederacionista. Diário de Notícias, Rio de Janeiro, 03 fev. 1934, Primeira Secção, p. 2.

CALHOUN, Craig; LIPUMA, Edward; POSTONE, Moishe. Bourdieu - a critical perspective. Cambridge: Polity Press, 1993.

CAMUS, Albert. A Peste. Disponível em: http://www.planonacionaldeleitura.gov.pt/clubedeleituras/upload/e_livros/clle000026.p df. Acesso em: 17 abr. 2014. 
CANDIDO, Antonio. Literatura e sociedade. Rio de Janeiro: Ouro sobre azul, 2006.

CANDIDO, Antonio. Iniciação à literatura brasileira. São Paulo: Humanitas, 1999.

CARVALHO, José Murilo. Os bestializados: a República que não foi. São Paulo: Companhia das Letras, 1987.

CARVALHO, José Murilo. Os três povos. In: HOMEM, Amadeu Carvalho; DA SILVA, Armando Malheiro. Progresso e religião: a República no Brasil e em Portugal 1889-1910. Coimbra: Imprensa da Univ. Coimbra, 2007, p. 131-164.

CARVALHO, Laerte Ramos de. A formação filosófica de Farias Brito. São Paulo: EDUSP/Editora Saraiva, 1977.

CENTRO D. VITAL de Recife, A Ordem, jul. 1935, p. 87-89.

CHAVES, André Aparecido Bezerra. A Revista da Faculdade Livre de Direito do Rio de Janeiro: uma proposta para a Identidade Jurídica Nacional Brasileira. 2011. 130 f. Dissertação (Mestrado em História Social) - Faculdade de Filosofia, Letras e Ciências Humanas, Universidade de São Paulo - USP, São Paulo, 2011.

CHENAUX, Philippe. La seconde vague thomiste. In : COLIN, Pierre. Intelectuels chrétiens et esprit des années 1920.Paris, Les Éditions du Cerf, 1997, p. 139 - 168.

CHENAUX, Philippe. Entre Maurras et Maritain: une génération intellectuelle catholique (1920-1930). Paris: Les Éd. du Cerf, 1999.

COMPAGNON, Olivier. Jacques Maritain et le modèle malgré lui. Paris: Septentrion, 2005 .

CONSELHO Penitenciário. O Paiz, Rio de Janeiro, 29 jan. 1926.

COSTA, Alexandre José Gonçalves. Teologia e política: a ordem e a atualização do discurso político-social católico no Brasil, 1931-1958. 2010. 262f. Tese. (Doutorado em História) - Instituto de Filosofia e Ciências Humanas, Universidade Estadual de Campinas - Unicamp, Campinas, 2010.

COSTA, João Cruz. Contribuições à História das Ideias no Brasil. Rio de Janeiro: José Olympio, 1956.

COSTA, Marcelo Timótheo. Um itinerário no século: mudança, disciplina e ação em Alceu Amoroso Lima. Rio de Janeiro/São Paulo: Ed. PUC-Rio/Loyola, 2006.

CÔRTES, Norma. Católicos e autoritários: breves considerações sobre a sociologia de Alceu Amoroso Lima, Revista Intellectus, Ano I, n.1, p. 1-14, 2004. 
CUNHA, Tristão da; ANDRADE, Oswald; CASCARAO, Hercolino. Para onde vae o Brasil?, Diário de Notícias, Rio de Janeiro, 28 maio 1933. Entrevista concedida a Diário de Notícias.

CUNNINGHAM, Lawrence. A Brief History of Saints. Massachussets: Blackwell, 2005.

D’ELBOUX, Luiz Gonzaga da Silveira. O Padre Leonel Franca. Rio de Janeiro: Editora Agir, 1953.

DEVER cultural dos catholicos (Editorial). A ordem, Rio de Janeiro, n. 26, p. 241-246, abr. 1932.

DIAS, Romualdo. Imagens de ordem: a doutrina católica sobre autoridade no Brasil (1922-1933). São Paulo: Ed. UNESP, 1996.

DICIONARIO literário brasileiro, v. 2. São Paulo: Saraiva, 1969, p. 364-365.

DINIZ, Marcelo Lucena. Os caminhos da intelectualidade católica na década de 1930: católicos e pioneiros na construção da ordem pública varguista. 2009. 159f. Dissertação (Mestrado em História) - Faculdade de História, Direito e Serviço Social, Universidade Estadual Paulista Julio de Mesquita Filho - Unesp, Franca, 2009.

DISCINI, Norma. Para o estilo de um gênero. Bakhtiniana, Rev. Estud. Discurso, v.7, n.2, p.75-94, 2012. Disponível em: http://www.producao.usp.br/handle/BDPI/40721. Acesso em: 17 abr. 2014.

DO NACIONALISMO na hora presente. Gazeta de Notícias, Rio de Janeiro, 11 abr.1921. Livros Novos.

DULLES, John W. F. Sobral Pinto: a consciência do Brasil a cruzada contra o regime Vargas (1930-1945). Rio de Janeiro: Nova Fronteira, 1991.

O DEVER cultural dos católicos, A ordem, n. 26, p. 241-246, abr. 1932. (editorial)

ELIAS, Norbert. Estabelecidos e Outsiders. Rio de Janeiro: Jorge Zahar, 1994.

ESTATUTOS do Centro D. Vital do Rio de Janeiro, A Ordem, ano XII, n. 11, p. 58-60, jan. 1931.

FARIAS, Damião Duque. Em defesa da Ordem: aspectos da práxis conservadora católica no meio operário em São Paulo (1930-1945). São Paulo: USP/Hucitec, 1998.

FAUSTO, Boris; DEVOTO, Fernando. Brasil e Argentina: um ensaio de história comparada. São Paulo: Editora 34, 2005. 
FERNANDES, Cléa de Figueiredo. Jackson de Figueiredo: uma trajetória apaixonada. Rio de Janeiro: Forense Universitária, 1989.

FIGUEIREDO, Jackson. Afirmações. Rio de Janeiro: Centro D. Vital/Tipografia Anuário do Brasil, 1921.

FIGUEIREDO, Jackson. Algumas reflexões sobre a filosofia de Farias Brito, 1916.

FIGUEIREDO, Jackson. Do nacionalismo na hora presente. Rio de Janeiro: Livraria Católica, 1921.

FIGUEIREDO, Jackson. Pascal e a inquietação moderna. Rio de Janeiro/Lisboa. Centro D. Vital/Anuário do Brasil/Renascença Portuguesa, 1922.

FIGUEIREDO, Jackson. Reação do bom senso: contra o demagogismo e a anarquia militar 'artigos publicados no O Jornal do Rio de Janeiro' (1921-1922). Rio de Janeiro: Annuario do Brasil, 1922.

FONSECA, Gondin da. A segunda encarnação dos Incitatus, Correio da Manhã, Rio de Janeiro, p. 4, 22 dez. 1935.

FRANCA, Leonel. A crise do mundo moderno. Rio De Janeiro: José Olímpio, 1941.

FRANCA, Leonel. Alocuções e artigos. Rio De Janeiro: Agir, 1954.

FRANCA, Leonel. Aspecto Social e Pedagógico do Ensino Religioso, Hierarquia, Rio de Janeiro, p. 8, ago. 1931.

FRANCA, Leonel. O divórcio. 6.ed. Rio de Janeiro: Agir, 1946.

FUSCO, Rosario. Depoimento de uma geração, Diário de Notícias, Rio de Janeiro, 19 jun. 1938. Vida literária, p. 2.

GABAGLIA, Laurita Pessôa Raja. O Cardeal Leme. Rio de Janeiro: Livraria José Olympio Editora, 1962.

GOMES, Angela de Castro. Essa gente do Rio. Rio de Janeiro: FGV, 1999.

GOMES, Angela de Castro. Os intelectuais cariocas, o modernismo e o nacionalismo: o caso de Festa. Luso-Brazilian Review, Winsconsin, v. 41, n. 1, p. 80-106, 2004.

GOMES, Angela de Castro. Silêncio e orações: as relações entre Estado, Igreja e Classe Trabalhadora no Pós-34. Revista História e Sociedade, Uberlândia, n. 14, v.2, p. 88$111,1987$. 
GOMES, Perillo. Jackson de Figueiredo: o doutrinador político. Rio de Janeiro: Centro D. Vital, 1926.

GOMES, Perillo. O liberalismo. Barcelona: Imprenta Boada, 1933.

GOMES, Perillo. Penso e creio. Rio de Janeiro/Lisboa: Anuario do Brasil/Renascença, 1921.

GOMES JÚNIOR, G. S. Crítica, combate e deriva do campo literário em Alceu Amoroso Lima. Tempo Social, São Paulo, v. 23, p. 101-133, 2011.

HACK, Osvaldo Henrique. Protestantismo e educação brasileira. São Paulo: Editora Cultura Cristã, 2000.

HALLEWELL, Laurence. A história do livro no Brasil. 2. ed. São Paulo: EDUSP, 2005.

HEDEN, Anthony. Rosário Fusco e o Estado Novo. 154f. Dissertação (Mestrado em Literatura Brasileira) - Programa de Pós Graduação em Literatura, Universidade Federal de Santa Catarina, Florianópolis, 2008.

HEINZ, Flávio. História social de elites. São Leopoldo: Oikos, 2011.

HEINZ, Flávio. Por outra história das elites. Rio de Janeiro: FGV, 2006.

HERVIEU-LÉGER, Danièle. O peregrino e o convertido: a religião em movimento. Petrópolis: Editora Vozes, 2008.

HOLANDA, Sergio Buarque de. O Ensino Religioso em face do livre pensamento, Hierarchia, Rio de Janeiro, ano 1, v. 1, p. 3-5, ago. 1931.

HUMILHADOS e luminosos. Gazeta de Notícias, Rio de Janeiro, 20 fev. 1921. Livros Novos.

IGLÉSIAS, Francisco. Estudo sobre o pensamento de Jackson de Figueiredo. In: História e ideologia. São Paulo: Perspectiva, p. 109-158, 1978.

JAPIASSÚ, Hilton \& MARCONDES, Danilo. Dicionário básico de filosofia. Rio de Janeiro: Jorge Zahar Editores, 2006, p. 113.

JUCÁ FILHO, Candido. Um livro grande de sociologia. Correio da Manhã, Rio de Janeiro, p. 2, 17 out. 1930.

JULIANO, Claudio. Religião por decreto, Diário de Notícias, Rio de Janeiro, 04 jun. 1931. 
JUSTIÇA Federal. Foi impronunciado. O Paiz, Rio de Janeiro, 05 jan. 1926. Tribunais e Juízos.

LACERDA, Carlos. Contra a má fé dos interessados, Diário de Notícias, Rio de Janeiro, 29 jun. 1932. Página de Educação, p. 6.

LACERDA, Carlos. Muito grave e muito comprometedor, Diário de Notícias, Rio de Janeiro, 25 maio 1932. Página de Educação.

LACERDA, Carlos. Phases e phrases do Sr. Reitor, Diário de Notícias, Rio de Janeiro, 27 maio de 1932. Página de educação, p. 6.

LAHIRE, Bernard. La condition littéraire: la double vie des écrivains. Paris : Édition La Découverte, 2006.

LIGA ELEITORAL CATÓLICA. In: Dicionário Histórico Biográfico Brasileiro. Disponível em: http://www.fgv.br/cpdoc/busca/Busca/BuscaConsultar.aspx. Acesso em 14 abr. 2014.

LIMA, Heitor. O divórcio na constituinte, Correio da Manhã, Rio de Janeiro, p. 2, 02 maio 1934.

LIMA, Heitor. Pela Verdade. Correio da Manhã, Rio de Janeiro, p. 2, 18 out. 1933.

LIMA, Heitor. Réplica a um mercador de meias. Correio da Manhã, Rio de Janeiro, p.2, 10 out. 1929.

LIMA, Heitor. Um grande cidadão, Correio da Manhã, Rio de Janeiro, p. 2, 07 nov. 1934.

LIMA, Hermes. A ofensiva clerical, A Manhã, Rio de Janeiro, p. 3, 31 maio 1935.

LIMA, Alceu Amoroso. A Posição dos Católicos frente ao liberalismo e à democracia. In: . A Ordem, out. 1944.

LIMA, Alceu Amoroso. Adeus à disponibilidade e outros adeuses. Rio de Janeiro: Agir, 1969.

LIMA, Alceu Amoroso. Contribuição à historia do modernismo: o pré-modernismo. Rio de Janeiro: José Olímpio, 1939.

LIMA, Alceu Amoroso. Da Tribuna e da Imprensa. Petrópolis: Vozes, 1935.

LIMA, Alceu Amoroso. Debates Pedagógicos. Estudos de Filosofia da Educação. Rio de Janeiro: Schmidt Editora, 1931. 
LIMA, Alceu Amoroso. Estudos. Rio de Janeiro: Edição Terra de Sol, 1928 (1 Série).

LIMA, Alceu Amoroso. Estudos. Rio de Janeiro, A Ordem, 1930 (3 $^{\text {a }}$ Série $-2^{\text {o }}$ Volume).

LIMA, Alceu Amoroso. Estudos literários. Rio de Janeiro: Companhia Aguilar Editora, v.1, 1966. [Coleção Biblioteca Luso-Brasileira]

LIMA, Alceu Amoroso. Haverá uma crise de espírito no mundo moderno?, Diário de Notícias, Rio de Janeiro, 14 jun. 1932.

LIMA, Alceu Amoroso. Idade sexo e tempo. Rio de Janeiro: José Olímpio, 1938.

LIMA, Alceu Amoroso. Meditação sobre o Mundo Moderno. Rio de Janeiro: José Olympio Editora, 1942.

LIMA, Alceu Amoroso. Memórias Improvisadas: diálogos com Medeiros Lima. Rio de Janeiro: Vozes/Educam, 2000.

LIMA, Alceu Amoroso. Mitos de nosso tempo. Rio de Janeiro: José Olímpio, 1942.

LIMA, Alceu Amoroso. No limiar da idade nova. Rio de Janeiro: José Olímpio, 1935.

LIMA, Alceu Amoroso. Notas para a História do Centro Dom Vital. Rio de Janeiro/São Paulo: Educam/Paulinas, 2001.

LIMA, Alceu Amoroso. O cardeal Leme. Rio de Janeiro: José Olímpio, 1943.

LIMA, Alceu Amoroso. O espírito e o mundo. Rio de Janeiro: José Olímpio, 1936.

LIMA, Alceu Amoroso. Pela união nacional. Rio de Janeiro: José Olímpio, 1942.

LIMA, Alceu Amoroso. Preparação à sociologia. Rio de Janeiro: Editora Centro Dom Vital, 1931.

LIMA, Alceu Amoroso; FIGUEIREDO, Jackson. Correspondência. Rio de Janeiro: Agir Editora, 1945.

LINS, Álvaro. Defesa do crítico católico, Diário de Notícias, Rio de Janeiro, 11 fev. 1940. Primeira Seção, Letras, artes, ideas geraes, p. 8.

LINS, Edison. A Academia de letras e a sociedade Felippe de Oliveira. Diário Carioca, Rio de Janeiro, p. 19, 18 abr. 1937. 
LOBATO, Monteiro. Críticas e outras Notas. 3 ed., São Paulo: Ed. Brasiliense, 1969, v. 18. (Obras Completas de Monteiro Lobato)

MAGALHÃES, Agamenon. Jackson de Figueiredo, Gazeta de Notícias, Rio de Janeiro, 02 nov. 1938.

MARTINS FILHO, Ives Gandra da Silva. Um pouco de História do Ministério Público do Trabalho. Revista do Ministério Público do Trabalho. Brasília: Ano VII, p. 28-35, 1 sem. 1997.

MENDES, Cândido. Leonel Franca: a disciplina da verdade. Síntese Nova Fase. Belo Horizonte, p. 163-172, v. 20 n. 61.

MENDONÇA, Edgard Sussekind de. A reforma do ensino e a escola nova, A Esquerda, Rio de Janerio, 10 maio 1928, p.1

MESQUIDA, Peri. A educação na restauração lemista da igreja: a missão de Tristão de Athayde e Stella de Faro no Ministério da Educação e Saúde Pública - 1934-1945, Rev. Diálogo Educ., Curitiba, v. 9, n. 27, p. 279-295, maio/ago. 2009.

MICELI, Sergio. A elite eclesiástica brasileira. São Paulo: Cia das Letras, 2009.

MICELI, Sergio. Experiência social e imaginário literário nos livros de estreia dos modernistas em São Paulo, Tempo social, São Paulo, v. 16, n. 1, jun. 2004.

MICELI, Sergio. (Org.) História das Ciências Sociais no Brasil. v. 1. São Paulo: Editora Sumaré, 2001.

MICELI, Sergio. História das Ciências Sociais no Brasil. v. 2. São Paulo: Editora Sumaré, 1995.

MICELI, Sergio. Intelectuais à Brasileira. São Paulo: Cia das Letras, 2001.

MOREYRA, Alvaro. Olha a frente, A Manhã, Rio de Janeiro, p. 3, 11 jun. 1935.

MOURA, Carlos André Silva de. Fé, saber e poder: os intelectuais entre a restauração católica e a política no Recife (1930-1937). Recife: Prefeitura Municipal de Recife, 2012 .

NAGLE, Jorge. Educação e sociedade na Primeira República. São Paulo: EPU/Edusp, 1974

NERIS, Wheriston Silva; SEIDL, Ernesto. O Episcopado Brasileiro e o Espaço do Poder: transformações da alta esfera eclesiástica. ENCONTRO ANUAL DA ANPOCS, 34., 2010, Caxambu. Anais... Caxambu, 2010. Disponível em: 
$<$ http://portal.anpocs.org/portal/index.php?option=com_docman\&task=doc_details\&gid $=1463 \&$ Itemid $=350>$. Acesso em: jul. 2013.

NOFUENTES, Vanessa Carvalho. Estratégias de mobilização da pátria: as ligas como lugar de mobilização social durante a Primeira República, Cadernos de História, v. VIII, ano 4, n. 2, dez. 2009, p. 54-67.

NOGUEIRA, Hamilton. Dostoiewski. Rio de Janeiro: Schmidt, 1935.

NOGUEIRA, Hamilton. Jackson de Figueiredo. Rio de Janeiro: Centro Dom Vital, 1928.

NOS BASTIDORES da Assemblea. Diário Carioca, Rio de Janeiro, 15 dez. 1933. Informações geraes, p. 3.

O CONGRESSO Eucharistico Nacional. Diário Carioca, Rio de Janeiro, 07 set. 1933. Noticiário, p. 2.

O CONGRESSO Eucharistico Nacional. Diário Carioca, Rio de Janeiro, 09 set. 1933. Colaborações, p.6.

O ENCERRAMENTO do Congresso Eucarístico Nacional, Correio da Manhã, 12 set. 1933.

O ENSINO religioso nas escolas: telegramas de protesto ao chegue de governo provisório. Diário Carioca, Rio de Janeiro, 06 maio 1931. Noticiário, p. 10.

O GRANDE Congresso Eucarístico da Bahia: a descrição que dele nos fez o Senhor Tristão de Athayde. Correio da Manhã, 17 set. 1933.

O NOVO membro da Academia de Letras, Diário de Notícias, 01/09/1935, p.5.

OLIVEIRA, Lúcia Lippi. Introdução. In: OLIVEIRA, Lúcia Lippi; GOMES, Eduardo Rodrigues; WHATELY, Maria Celina. Elite intelectual e debate político nos anos 30. Rio de Janeiro/Brasília: Fundação Getúlio Vargas/INL, 1980, p. 31-60.

OLIVEIRA, Lúcia Lippi. Constelação Capanema: intelectuais e políticas. Rio de Janeiro: FGV, 2001.

PADRE Leonel Franca. Jornal do Brasil, 05 set. 1948, p. 8.

PAIM, Antonio. O estudo do pensamento filosófico brasileiro. Rio de Janeiro: Tempo Brasileiro, 1979. 
PARA DIFUNDIR os princípios catholicos: sob a direção intelectual de Tristão de Athayde. Diário Carioca, Rio de Janeiro, p. 8, 30 out. 1936.

PASCAL e a inquietação moderna. Gazeta de Notícias, Rio de Janeiro, 07 jul. 1922. Livros Novos.

PASSIANI, Enio. Na trilha do Jeca: Monteiro Lobato o público leitor e a formação do campo literário no Brasil. Sociologias, Porto Alegre, ano 4, n. 7, jan/jun 2002, p. 254270 .

PATRIA, João. Ensaia-se o comunismo no ensino, Diário de Notícias, Rio de Janeiro, 19 abr. 1932. A pedidos, p. 4.

PATRIA, João. Prossegue impávida a orientação bolshevista do ensino municipal, Diário de Notícias, Rio de Janeiro, 28 jun. 1932. A pedidos, p. 4.

PAULA, Christiane Jalles de. Espaços de sociabilidade e relações de poder na igreja católica brasileira: o Centro Dom Vital através das trajetórias de Jackson de Figueiredo e de Gustavo Corção. In: Encontro Anual da Anpocs, 34, Caxambu. Apresentação de trabalho, 2011. Disponível em: <http://observatory-elites.org/anpocsgt2010>. Acesso em: jan. 2013.

PÉCAUT, Daniel. Os intelectuais e a política no Brasil. São Paulo: Ed. Ática, 1990.

PESSÔA, Frota. A apostasia de um leader, Diário de Notícias, Rio de Janeiro, 29 maio 1931, Página de Educação, p. 7.

PESSÔA, Frota. A reforma da instrução e o ensino religioso. Diário de Notícias, Rio de Janeiro, 08 maio 1931, Página de Educação, p. 7.

PINHEIRO FILHO, Fernando Antonio. A Invenção da Ordem: intelectuais católicos no Brasil. Tempo Social, São Paulo, v.19, n.1, p.33-49, jun. 2007.

PLANO de Ação, Vida, Ano I n. 1, p. 1, abr. 1934. (editorial)

PONTES, Heloísa. Brasil com Z: a produção estrangeira sobre o país editada aqui sob a forma de livro entre 1930 e 1988. In: MICELI, Sergio (Org.). História das Ciências Sociais no Brasil. São Paulo: Editora Sumaré/FAPESP, 1995.

REZENDE, Garcia de. Entre Deus e o Diabo, Diário de Notícias, Rio de Janeiro, p. 3, 21 abr. 1931.

ROCQUE, Francisco Augusto de la, O comunismo universitário e a liberdade de cátedra, Vida Revista Universitária, ano 1, n. 2, maio 1934. 
RODRIGUES, Cândido Moreira. A Ordem: uma revista de intelectuais católicos. Belo Horizonte: Autêntica, 2006.

RODRIGUES, Cândido Moreira. Alceu Amoroso Lima: matrizes e posições de um intelectual católico militante em perspectiva histórica (1928-1946). 2006. 319f. Tese. (Doutorado em História) - Faculdade de Ciências e Letras, Universidade Estadual Paulista Júlio de Mesquita Filho - UNESP, Assis, 2006.

RODRIGUES, Cândido Moreira. Aproximação e conversões: o intelectual Alceu Amoroso Lima no Brasil dos anos 1928 - 1946. São Paulo: Editora Alameda, 2012.

RODRIGUES, Cândido Moreira; PAULA, Christiane Jalles de. Intelectuais e militância católica no Brasil. Cuiabá: Editora UFMT, 2012.

RODRIGUES, Leandro Garcia (Org.). Correspondência: Alceu Amoroso Lima \& Mario de Andrade. São Paulo: Edusp, 2014 (no prelo).

RODRIGUES, Leôncio Martins. O PCB: os dirigentes e a organização. In: FAUSTO, Boris (Dir.). O Brasil Republicano. Rio de Janeiro: Bertrand Brasil, 2007, v. 3Sociedade e política (1930-1964), p. 431-532. (História Geral da Civilização Brasileira, $10)$.

SAMPAIO, Newton. Mestre Eloy, Diário de Notícias, Rio de Janeiro, p. 3, 12 set. 1937.

SAVIOZ, R. Georg Kerschensteiner. In: CHÂTEAU, Jean. Los Grandes Pedagogos. México: Fondo de Cultura Económica, 1992, p. 234-237.

SCHINCARIOL, Marcelo Tadeu. A arte complexa de ser infeliz: a ficção de Cornélio Penna. Campinas: UNICAMP, 2009. 385f. Tese (Doutorado em Teoria e História Litetária) - Instituto de Estudos da Linguagen-IEL, Unicamp, Campinas, 2009.

SCHWARCZ, Lilia Moritz. História do Brasil Nação (1808-2010). Rio de Janeiro: Objetiva, 2012. (Vol. 3: A abertura para o mundo 1889-1930).

SCHWARTZMAN, Simon; BOMENY, Helena Maria Bousquet; COSTA, Vanda Maria Ribeiro. Tempos de Capanema. São Paulo: Paz e Terra/Editora FGV, 2000.

SERRANO, Jonathas. Farias Brito: o homem e a obra. São Paulo: Companhia Editora Nacional, 1939.

SERRANO, Jonathas. Júlio Maria. Rio de janeiro: Livraria Boa Imprensa, 1941. 
SERVA, Mario Pinto. O Salvador Mystico, Diário Carioca, Rio de Janeiro, 29 maio 1931. Correspondências especiais, p. 2.

SEVCENKO, Nicolau. Literatura como missão: tensões sociais e criação cultural na Primeira República. São Paulo: Companhia das Letras, 2003.

SILVA, Ana Paula Barcelos Ribeiro. Fidelino de Figueiredo e Jonathas Serrano: pensamento católico e radicalização política na década de 1930 - algumas reflexões. Passagens. Revista Internacional de História Política e Cultura Jurídica, Rio de Janeiro, v. 2 n.4, maio-ago. 2010, p. 39-66.

SILVA, Giovane José da. O Batismo de Clio: Jonathas Serrano e a historiografia católica na Primeira República. In: NICOLAZZI, Fernando, MOLLO, Helena; ARAUJO, Valdei (Org.). SEMINÁRIO NACIONAL DE HISTÓRIA DA HISTORIOGRAFIA: tempo presente \& usos do passado, 4., 2010, Anais... Ouro Preto: EdUFOP, 2010.

SILVA, Simone. As rodas literárias no Brasil nas décadas de 1920-30: troca e obrigações no mundo do livro. Latitude, v. 2, n.2, p.182-210, 2008.

SIRINELLI, Jean-François. Intelectuais. In: REMOND, René. Por uma história Política. Rio de Janeiro: Editora UFRJ, 1996.

S. PAULO, Diário de Notícias, Rio de Janeiro, 04 jun. 1931, Do Amazonas ao Prata, p.6.

SORÁ, Gustavo. Brasilianas: José Olympio e a gênese do mercado editorial brasileiro. São Paulo: Edusp, 2010.

SOUZA, José Pedro Galvão. Atividades universitárias, Vida Revista Universitária, ano 1, n. 2, maio 1934.

SOUZA, José Pedro Galvão, Tendências políticas da mocidade católica, Vida Revista Universitária, ano 1, n. 1, abr. 1934.

STONE, Lawrence. Prosopografia, Revista de Sociologia e Política, Curitiba, v. 19, n. 39, p. 115-137, jun. 2011.

SUCUPIRA FILHO, Eduardo. Com que roupa, A Manhã, Rio de Janeiro, p. 3, 05 jun. 1935.

UM LIVRO de Jackson de Figueiredo apreciado em Portugal, Gazeta de Notícias, Rio de Janeiro, 03 maio 1923. Livros Novos. 
VIANNA, Oliveira. Os Estudos Sociológicos do Brasil, Hierarquia, Rio de Janeiro, ano 1, v. 1, p. 14-15, ago. 1931.

VILAS-BÔAS, Ester. Origens da educação protestante em Sergipe (1884-1913). In: CONGRESSO BRASILEIRO DE HISTÓRIA DA EDUCAÇÃO, 1., 2000, Rio de Janeiro. Anais eletrônicos...Rio de Janeiro: UFRJ, 2000. Disponível em: $\langle$ http://www.sbhe.org.br/novo/congressos/cbhe1/anais/051_ester_fraga.pdf $>$. Acesso em: jan. 2013.

WENERCK SODRÉ, Nelson. História da imprensa no Brasil. Rio de Janeiro: Mauad, 1999.

WILLIAMS, Raymond. O círculo de Bloomsbury. In: Cultura e materialismo. São Paulo: Unesp, 2005, p. 201-230.

WINOCK, Michel. Esprit: Des intellectuels dans la cité 1930-1950. Paris: Éditions du Seiul, 1995.

ZANATTA, Regina Maria. Jonathas Serrano e a escola nova no Brasil: raízes católicas na corrente progressista. 2005. 205fls. Tese (Doutorado em Educação Filosofia da Educação) - Faculdade de Educação, Universidade de São Paulo - USP, São Paulo, 2005 . 